\title{
Lokaal integraal gezondheidsbeleid: realistische uitdaging of utopie? : Een onderzoek binnen gemeenten naar mogelijkheden tot intersectorale samenwerking
}

Citation for published version (APA):

Steenbakkers, W. H. L. (2012). Lokaal integraal gezondheidsbeleid: realistische uitdaging of utopie? : Een onderzoek binnen gemeenten naar mogelijkheden tot intersectorale samenwerking. [Doctoral Thesis, Maastricht University]. Maastricht University. https://doi.org/10.26481/dis.20120927ws

Document status and date:

Published: 01/01/2012

DOI:

$10.26481 /$ dis.20120927ws

Document Version:

Publisher's PDF, also known as Version of record

Please check the document version of this publication:

- A submitted manuscript is the version of the article upon submission and before peer-review. There can be important differences between the submitted version and the official published version of record. People interested in the research are advised to contact the author for the final version of the publication, or visit the DOI to the publisher's website.

- The final author version and the galley proof are versions of the publication after peer review.

- The final published version features the final layout of the paper including the volume, issue and page numbers.

Link to publication

\footnotetext{
General rights rights.

- You may freely distribute the URL identifying the publication in the public portal. please follow below link for the End User Agreement:

www.umlib.nl/taverne-license

Take down policy

If you believe that this document breaches copyright please contact us at:

repository@maastrichtuniversity.nl

providing details and we will investigate your claim.
}

Copyright and moral rights for the publications made accessible in the public portal are retained by the authors and/or other copyright owners and it is a condition of accessing publications that users recognise and abide by the legal requirements associated with these

- Users may download and print one copy of any publication from the public portal for the purpose of private study or research.

- You may not further distribute the material or use it for any profit-making activity or commercial gain

If the publication is distributed under the terms of Article 25fa of the Dutch Copyright Act, indicated by the "Taverne" license above,

Download date: 26 Apr. 2023 
Academische Werkplaats

Publieke Gezondheid Limburg

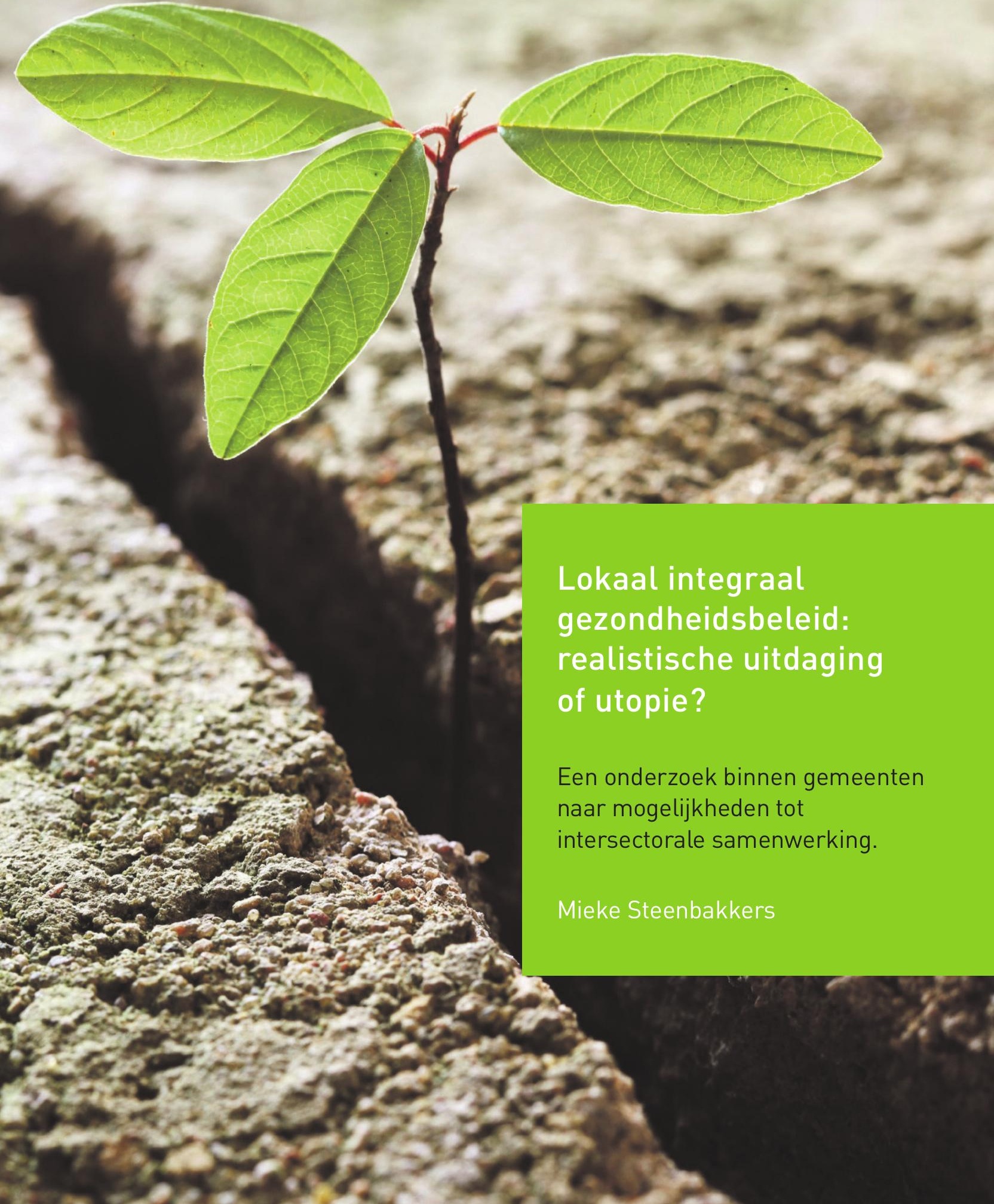




\section{Lokaal integraal gezondheidsbeleid: realistische uitdaging of utopie?}

Een onderzoek binnen gemeenten naar mogelijkheden tot intersectorale samenwerking

Mieke Steenbakkers,

Academische Werkplaats Publieke Gezondheid Limburg 
Integrating Health in all Policies: realistic challenge or utopia?

A study of the opportunities for inter-sectoral collaboration within Dutch municipal governments to stimulate integrated health policy

Mieke Steenbakkers,

Academic Collaborative Centre for Public Health Limburg, Maastricht 


\section{Lokaal integraal gezondheidsbeleid: realistische uitdaging of utopie?}

Een onderzoek binnen gemeenten naar mogelijkheden tot intersectorale samenwerking

\author{
Proefschrift
}

Ter verkrijging van de graad doctor aan de Universiteit Maastricht, op gezag van de Rector Magnificus, Prof. Dr. L.L.G. Soete, volgens het besluit van het College van Decanen,

Copyright: Mieke Steenbakkers, Maastricht, 2012

Design \& lay-out: Caris \& Sak, Heerlen

ISBN: 978-90-815704-0-4

Alle rechten zijn voorbehouden. Illustraties en tekst van deze publicatie mogen voor wetenschappelijke, educatieve en praktische doeleinden worden gebruikt met vermelding van de bron.

De studies beschreven in dit proefschrift zijn gefinancierd door de Nederlandse organisatie voor gezondheidsonderzoek en zorginnovatie (projectnr. 7125.0001) met aanvullende financiering van de Academische Werkplaats Publieke Gezondheid Limburg.

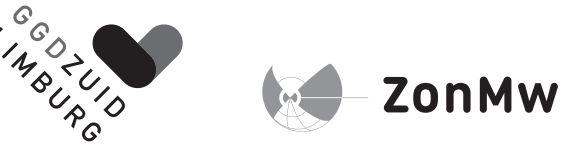

in het openbaar te verdedigen op donderdag 27 september 2012 om 12.00 uur doo

Wilhelmina Hendrika Lamberta Steenbakkers 


\section{Praktijkcommissie:}

Drs. J. Costongs, wethouder gemeente Maastricht

Dr. J. ten Dam, Lectoraat De Gezonde Stad, Windesheim, Zwolle

Mw. Dr. M. Hoeijmakers, Gezondheid in Beweging, Maasbree

Dhr. R. Stijns, hoofd afdeling Kennis \& Innovatie, GGD Zuid Limburg

Promotoren:

Prof. Dr. N.K. de Vries

Prof. Dr. J.A.M. Maarse

Co-promotor:

Mw. Dr. Ir. M.W.J. Jansen

Beoordelingscommissie:

Prof. Dr. D. Ruwaard (voorzitter)

Prof. Dr. G.J. Kok

Prof. Dr. C. Spreeuwenberg

Mw. Prof. Dr. M.C.H. Donker (Erasmus MC, Rotterdam)

Mw. Prof. Dr. Ir A.J. Schuit (Vrije Universiteit Amsterdam)

Dit proefschrift is tot stand gekomen vanuit de Academische Werkplaats Publieke Gezondheid Limburg, een samenwerkingsverband tussen de GGD Zuid Limburg, de faculteit Health, Medicine and Life Sciences van de Universiteit Maastricht en de 18 Zuid-Limburgse gemeenten. Het gepresenteerde onderzoek is uitgevoerd bij de School for Public Health and Primary Care: CAPHRI.

The research presented in this thesis was conducted at the School for Public Health and Primary Care: CAPHRI, Department Health Promotion of Maastricht University. CAPHRI participates in the Netherlands School of Primary Care Research CaRe. CAPHRI was classified as 'excellent' by the external evaluation committee of leading international experts that reviewed CAPHRI in December 2010 
“Professionals zouden hun werk meer moeten inrichten als een-leven-lang-leren"

Dit proefschrift draag ik op aan:

- $\quad$ mijn moeder, die deze mijlpaal helaas niet meer kan meemaken. Mam, bedankt dat je me hebt gestimuleerd om te gaan studeren, een kans die je zelf helaas nooit hebt gekregen.

- mijn beide zonen Nicolas en Etienne,

daar ik hoop dat zij net als ik het plezier vinden

om hun persoonlijke talenten door te ontwikkelen in een-leven-lang-leren. 


\section{Inhoudsopgave}

Hoofdstuk $1 \quad$ Introductie

Hoofdstuk 2 Lokaal integraal gezondheidsbeleid:

intersectorale samenwerking vanuit het perspectief van gemeenten

Gepubliceerd in TSG (2010): 88 (3): 136-143

Hoofdstuk 3 Gemeentelijke intersectorale samenwerking stimuleren:

lokale begeleiding bij het ontwikkelen van integraal gezondheidsbeleid

Gepubliceerd in TSG (2011); 89 (5): 266-273

Hoofdstuk $4 \quad$ Sturing op integraal gezondheidsbeleid:

de rol van het gemeentelijke management

Gepubliceerd in TSG (2012); 90 (2): 89-96

Hoofdstuk 5

Lokaal integraal gezondheidsbeleid:

effecten van beleidsondersteuning op de ontwikkeling van

gemeentelijke intersectorale samenwerking en integraal beleid

Gepubliceerd in TSG (2012); 90 (3): 184-192

Hoofdstuk 6

Challenging Health in All Policies,

an action research study in Dutch municipalities

Gepubliceerd in Health Policy (2012); 105 (2-3): 288-295

Hoofdstuk 7 Discussie

Samenvatting

Summary

Dankwoord

Curriculum Vitae 


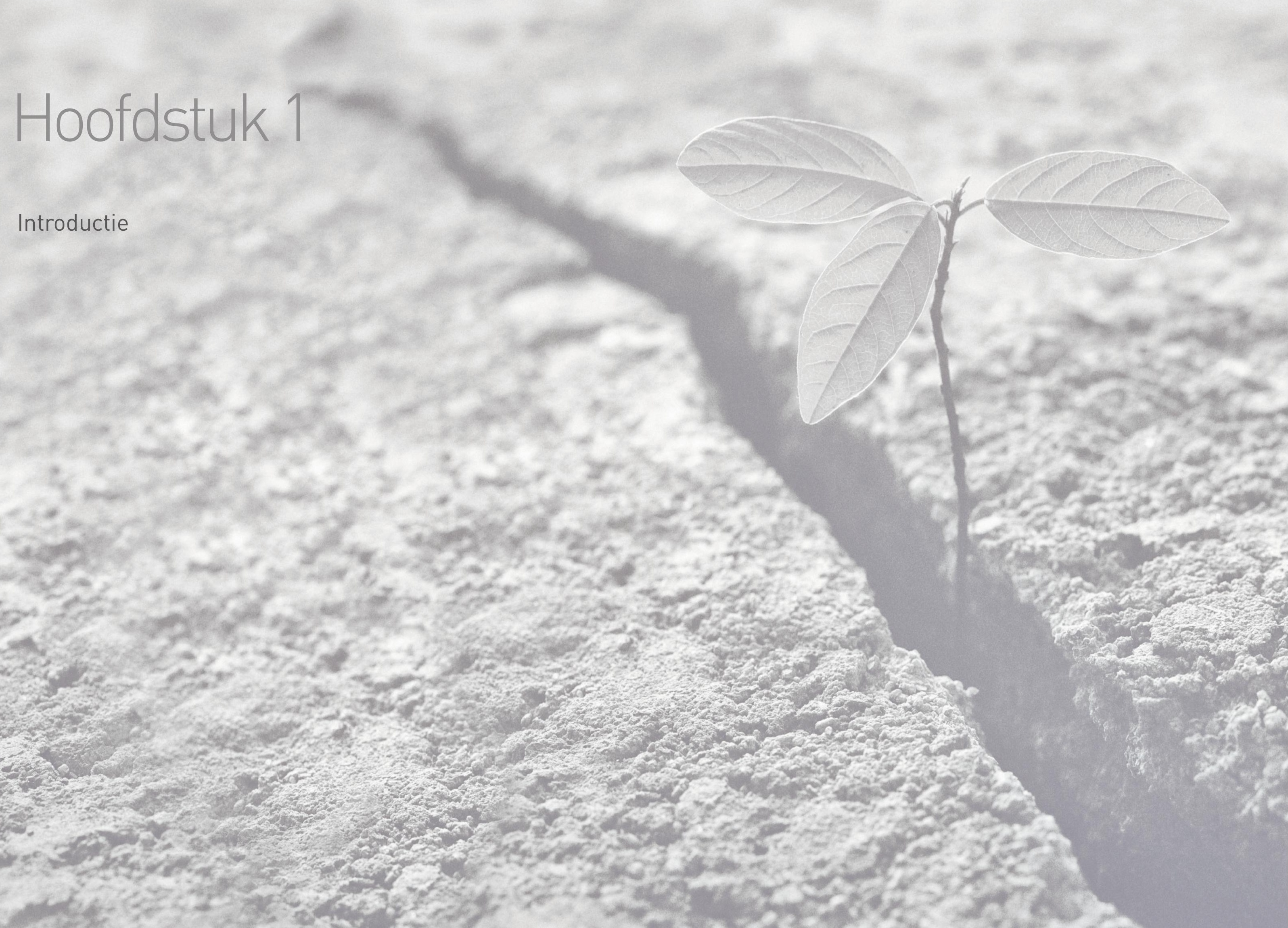




\subsection{Inleiding}

De basis voor onze huidige visie op de volksgezondheid werd al ruim een eeuw geleden gelegd. In de eerste helft van de negentiende eeuw gaven de publieke hygiënisten in Europa aan dat ziekte proactief moest worden bestreden met collectieve en preventieve hygiënemaatregelen gericht op gezondheidsbescherming, zoals bijvoorbeeld sanitaire voorzieningen en schoon drinkwater. Het inzicht groeide dat lon)gezondheid niet louter een individuele aangelegenheid is, maar ook wordt beïnvloed door de omstandigheden waarin mensen leven en werken. Gezondheid werd niet langer uitsluitend gezien als afwezigheid van ziekte. In 1948 kwam de WHO met een definitie waarin gezondheid wordt omschreven als een staat van compleet fysiek, mentaal en sociaal welbevinden (1). Deze andere kijk op gezondheid heeft er onder andere toe geleid dat de Nederlandse overheid zich in de loop der jaren actief is gaan bemoeien met de inrichting van de gezondheidszorg. Zo ontstonden er bijvoorbeeld Gemeentelijke Geneeskundige en GezondheidsDiensten (GG\&GD) van waaruit de eerste preventieve gezondheidsprogramma's werden opgestart voor kwetsbare groepen, zoals zwangeren, pasgeborenen en jeugdigen (2). Volksgezondheidsproblemen kregen een steeds duidelijkere publieke dimensie en de term publieke gezondheid werd geïntroduceerd en in 2008 opgenomen in wetgeving en beleid $(3,4)$. Kortom, maatschappelijke ontwikkelingen beïnvloeden onze visie op gezondheid. Recentelijk is de World Health Organization (WHO) definitie van gezondheid internationaal ter discussie gesteld. Door de technische vooruitgang en demografische veranderingen (met name de vergrijzing) is het leven met een chronische ziekte eerder regel dan uitzondering geworden. Vandaar dat Huber en haar collega's in 2011 ervoor pleiten om gezondheid anders te definiëren, namelijk meer vanuit individuele mogelijkheden om met sociale, fysieke en emotionele uitdagingen om te gaan en minder vanuit compleet welbevinden (5). Gezondheid wordt gezien als het vermogen e aan te passen aan de ups en downs in lichamelijk en geestelijk functioneren en maatschappelijke participatie (6). Het kunnen blijven participeren in de samenleving is hierbij een nieuw centraal uitgangspunt geworden van gezondheid.

Met het inzicht dat de publieke gezondheid wordt beïnvloed door verschillende individuele en maatschappelijke factoren groeit ook het besef dat zowel de gezondheidssector zelf als sectoren buiten de gezondheidszorg belangrijk zijn voor het bevorderen van de volksgezondheid (7-9). Dahlgren \& Whitehead ontwikkelden een model, waarmee zij de onderlinge beïnvloeding tussen het individu, zijn omgeving, en ziekte en gezondheid in kaart brengen (zie Figuur 1.1) (10). 


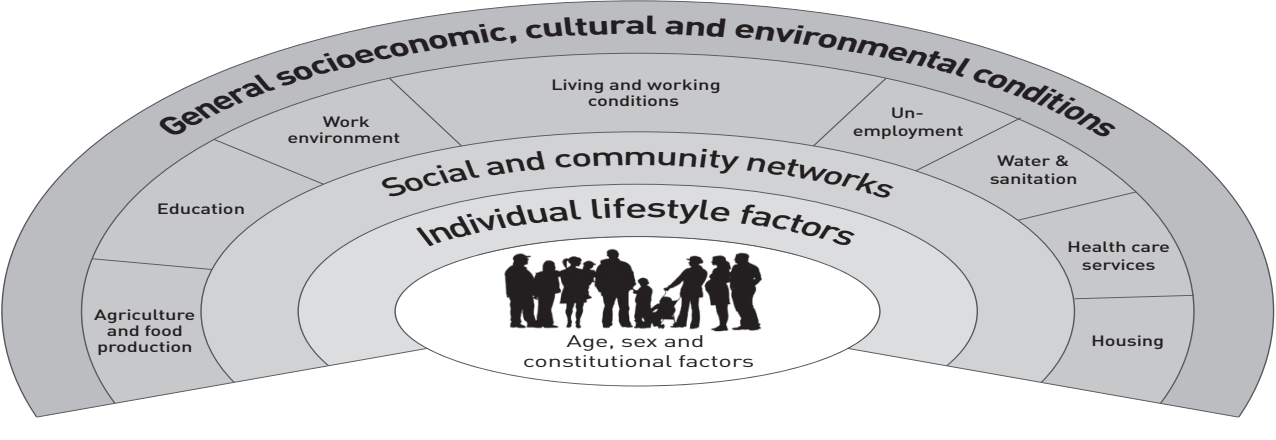

Figuur 1.1: Social Model of Health (10)

In het midden van dit model staat het individu met zijn leeftijd en een aantal vaststaande erfelijke factoren, zoals geslacht en de lichamelijke en geestelijke constitutie, die hoegenaamd niet te beïnvloeden zijn. Maar het individu wordt omringd door allerlei factoren die wel beïnvloedbaar zijn. Allereerst zijn dat de individuele leefstijlfactoren die de gezondheid kunnen bevorderen of bedreigen, zoals de keuze van een individu om te roken of te sporten. Ook sociale en omgevingsnetwerken zijn van invloed op de gezondheid omdat zij het individu positief dan wel negatief kunnen beïnvloeden in bepaalde levensfasen. Een individu kan zelf actief participeren in netwerken, maar ook door familie, vrienden, de buurt, het welzijnswerk of de lokale overheid gestimuleerd worden deel te nemen aan clubs of activiteiten. En uiteraard wordt de gezondheid van het individu ook beïnvloed door sociaal-economische, culturele en omgevingsfactoren, zoals werkloosheid, huisvesting, opleiding en de aanwezigheid van bepaalde voorzieningen.

Het model van Dahlgren \& Whitehead maakt duidelijk dat diverse factoren een rol spelen bij het bevorderen van de volksgezondheid en dat de inzet vanuit verschillende sectoren belangrijk is. In feite is volksgezondheid een verantwoordelijkheid van ons allen, het gehele publieke en private domein. Dit roept de vraag op hoe de elementen in de verschillende ringen van het model beïnvloed kunnen worden. De overheid speelt in dit kader een belangrijke rol. Vanuit de Wet publieke gezondheid zijn gemeenten medeverantwoordelijk voor de volksgezondheid van hun burgers (3). Hoewel mensen uiteraard zelf bepalen wat en hoeveel ze eten of in welke mate ze bewegen, kan de verantwoordelijkheid voor een gezondheidsprobleem zoals overgewicht niet alleen bij het individu gelegd worden. Ondersteunende maatregelen gericht op de fysieke en sociale omgeving zijn even noodzakelijk, denk aan wandel- en fietspaden en speelvoorzieningen in de wijk, aangezien een deel van het gezondheidsprobleem overgewicht immers mede wordt veroorzaakt door de 'obesogene' omgeving (11-13), dat wil zeggen een omgeving die ongezond eten en te weinig bewegen stimuleert. Dan rijst de vraag welke mogelijkheden gemeentelijke overheden hebben om de publieke gezondheid te bevorderen, om verbindingen te leggen tussen allerlei sectoren die invloed hebben op gezondheid. Beperkte financiële middelen voor gezond- heidsbeleid en het feit dat ondersteunende maatregelen gericht op de fysieke en sociale omgeving noodzakelijk zijn om gedragsverandering bij burgers te realiseren $(12,13)$ maken afstemming tussen gemeentelijke beleidsterreinen noodzakelijk. Actoren binnen diverse gemeentelijke beleidsterreinen zijn zich vaak niet bewust van de invloed die het eigen beleid heeft op de publieke gezondheid (14). Dit proefschrift richt zich op de vraag of gemeenten gestimuleerd kunnen worden tot meer intersectorale samenwerking en integrale beleidsontwikkeling ten aanzien van het gezondheidsprobleem overgewicht. Welke mogelijkheden zijn er om intern binnen de eigen gemeentelijke organisatie te werken aan samenhangend intersectoraal gezondheidsbeleid, in zijn algemeenheid en specifiek voor overgewicht? Is een dergelijke integrale beleidsontwikkeling een realistische uitdaging voor gemeenten of is hier sprake van utopie?

Om verschillende hoofdstukken van dit proefschrift goed te kunnen plaatsen wordt in dit inleidende hoofdstuk eerst het kader geschetst waarbinnen het onderzoek heeft plaatsgevonden. Er wordt stil gestaan bij de definitie van integraal gezondheidsbeleid en het gebruik van deze term door gemeenten, de wettelijke grondslag van het gemeentelijke gezondheidsbeleid, de nieuwe kansen vanuit de Wet maatschappelijke ondersteuning (Wmo) om gezondheid te verbinden aan maatschappelijke participatie, de landelijke tendens om zorgtaken te decentraliseren en het belang van intersectorale samenwerking bij complexe gezondheidsproblemen. Tevens wordt de relatie tussen een GGD en haar gemeenten beschreven, de verschillende bestuursvormen, de wettelijke taken en de gemeentelijke rol van opdrachtgever én opdrachtnemer. Vervolgens wordt ingegaan op de focus van dit onderzoek, het gebruikte conceptuele model, het uitgevoerde gemeentelijke begeleidingstraject om de ontwikkeling van integraal gezondheidsbeleid voor overgewicht te stimuleren, de onderzoeksvragen en de methoden van onderzoek. De verschillende hoofdstukken van dit proefschrift beschrijven de resultaten naar aanleiding van de onderzoeksvragen die binnen dit onderzoek zijn geformuleerd.

\subsection{Integraal gezondheidsbeleid}

\section{Wat is beleid?}

In de literatuur wordt beleid gedefinieerd als het aangeven van de richting en de benodigde middelen om gestelde doelen te realiseren, waarbij plaats en tijd duidelijk zijn omschreven. De middelen, ook wel beleidsinstrumenten genoemd, kunnen bestaan uit:

- communicatieve beleidsinstrumenten zoals voorlichting, overleg, een pleidooi of propaganda;

- economische beleidsinstrumenten zoals subsidieverstrekking, heffingen of inzet van bijvoorbeeld ambtenaren;

- juridische beleidsinstrumenten zoals overeenkomsten, richtlijnen, vergunningen, wetten of sancties. 
Zowel tussen de doelen als tussen de middelen die worden ingezet dient onderlinge samenhang te bestaan (15).

\section{Definitie en toepassing in de praktijk}

Internationaal wordt integraal gezondheidsbeleid steeds vaker genoemd als een strategie om hedendaagse, complexe volksgezondheidsproblemen aan te pakken $(8,9,16-20)$. Er is een groeiende politieke belangstelling voor deze strategie in Nederland en Europa (21). De WHO gebruikt voor integraal gezondheidsbeleid de term: 'Health in All Policies (HiAP)'. Een mooi voorbeeld van HiAP is EU-gedragsartikel 152, dat in 2001 verscheen, waarin is bepaald dat in iedere activiteit of ieder beleid van de $\mathrm{EU}$ een hoog niveau van volksgezondheid verzekerd moet worden (22). Dit politieke belang van HiAP is door de EU herbevestigd in het verdrag van Lissabon in 2007 (23). In Nederland stimuleert het Ministerie van Volksgezondheid, Welzijn en Sport (VWS) gemeenten om lokaal integraal gezondheidsbeleid te ontwikkelen (3, 24-30). Het is echter niet altijd eenvoudig om te bepalen of een bepaald beleid ook daadwerkelijk integraal gezondheidsbeleid is. Onderstaand schema van Storm kan dan behulpzaam zijn (zie figuur 1.2).

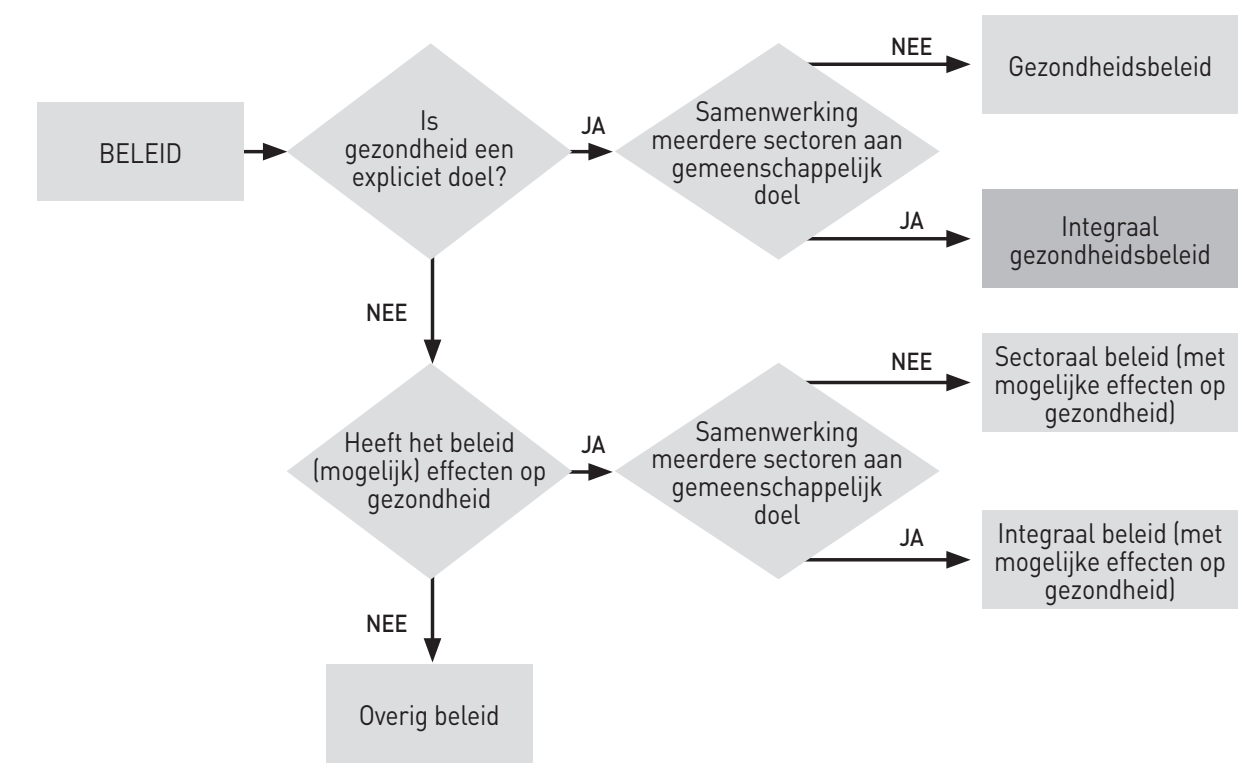

Figuur 1.2: Wanneer is er sprake van integraal gezondheidsbeleid? (22)

In dit schema wordt de volgende definitie van integraal gezondheidsbeleid gehanteerd: beleid waarbij de relevante sectoren binnen en buiten het volksgezondheidsdomein samenwerken aan het aspect gezondheid, samen beleid maken, waarbij het gemeenschappelijk doel is het bevor- deren of beschermen van de gezondheid. Wanneer in het beleid gezondheid een expliciet doet is, maar de samenwerking tussen diverse actoren uitsluitend plaatsvindt binnen het volksgezondheidsdomein is er sprake van gezondheidsbeleid. Gezondheidsbeleid is in feite een vorm van sectoraal beleid (samenwerking vindt uitsluitend plaats binnen één sector).

Bij integraal beleid vindt er samenwerking met meerdere sectoren plaats, maar is gezondheid niet als expliciete doelstelling opgenomen in het beleid van een andere sector. Dit beleid heeft mogelijk wel - positieve dan wel negatieve - effecten op de gezondheid. De tegenhanger van integraal beleid is sectoraal beleid waarbij er geen samenwerking met andere sectoren plaatsvindt en gezondheid niet als expliciete doelstelling is opgenomen in het beleid. Kenmerkend voor integraal gezondheidsbeleid is verder dat de overheid de belangrijkste actor is naast andere actoren zoals belangengroepen, bedrijven en instellingen. Verschillende sectoren maken samen integraal gezondheidsbeleid dat kan plaatsvinden op lokaal, nationaal of internationaal (bijvoorbeeld Europees) niveau (22). Integraal gezondheidsbeleid is geen doel op zich, maar wel een aanbevolen manier om complexe gezondheidsproblemen zoals overgewicht aan te pakken (31-33).

Intersectorale samenwerking, samenwerking tussen verschillende beleidssectoren op hetzelfde bestuursniveau (34), is een belangrijke voorwaarde om integraal gezondheidsbeleid te kunnen ontwikkelen (18).

Binnen Nederlandse gemeenten wordt de term integraal gezondheidsbeleid heel uiteenlopend gebruikt (33) (zie tabel 1.1). Vaak blijkt het dan te gaan om gezondheidsbeleid lalleen vanuit domein volksgezondheid (VGZ)), een integrale aanpak (met meerdere partijen samenwerken binnen een setting), publiek-private samenwerking (interne en externe gemeentelijke samenwerkingl of sectoraal beleid (tussen diverse sectoren maar zonder de sector VGZ).

Tabel 1.1: Gebruik van de term integraal gezondheidsbeleid in de praktijk (33)

\begin{tabular}{ll} 
Gebruik term integraal gezondheidsbeleid in de praktijk & Theoretische term \\
$\begin{array}{l}\text { Beleid binnen het VGZ domein, waarbij samenwerken mogelijk is tussen } \\
\text { een of meerdere sectoren binnen VGZ domein. }\end{array}$ & Gezondheidsbeleid \\
\hline $\begin{array}{l}\text { Werkwijze waarbij een volksgezondheidsprobleem met meerdere partijen } \\
\text { wordt aangepakt binnen diverse settings (school, wijk, zorg). }\end{array}$ & Integrale aanpak \\
\hline $\begin{array}{l}\text { Samenwerken tussen beleidssectoren en verschillende externe partijen. } \\
\text { Deze partijen kunnen ook andere publieke en/of private partijen zijn. }\end{array}$ & $\begin{array}{l}\text { Publiek-private } \\
\text { samenwerking }\end{array}$ \\
\hline $\begin{array}{l}\text { Samenwerken tussen meerdere beleidssectoren aan een gemeen- } \\
\text { schappelijk doel (maar gezondheid is geen hoofddoel). }\end{array}$ & Integraal beleid \\
\hline $\begin{array}{l}\text { Beleid buiten het VGZ domein met mogelijke effecten op gezondheid, } \\
\text { maar waarbij geen samenwerking is met het VGZ domein. }\end{array}$ & Sectoraal beleid \\
\hline
\end{tabular}


Er zijn dus veel verschillende invullingen van de term integraal gezondheidsbeleid binnen gemeenten waarbij opvalt dat het vaak gaat om integrale uitvoering van beleidsmaatregelen of interventies en veel minder om een integrale beleidsontwikkeling (samen beleid maken).

In feite staat de ontwikkeling van integraal gezondheidsbeleid binnen Nederlandse gemeenten nog in de kinderschoenen (35). Ook blijken begrippen zoals intersectorale samenwerking en integraal gezondheidsbeleid lastig te conceptualiseren, er worden geen eenduidige theoretische perspectieven gebruikt. Dit belemmert de theorievorming en een adequate interpretatie van de beperkt beschikbare onderzoeksgegevens (36). In de praktijk blijken beleidsmakers verschillende barrières te ervaren om intersectoraal samen te werken en integraal gezondheidsbeleid te ontwikkelen $(33,37)$. Zo is de betrokkenheid vanuit andere beleidssectoren bij gezondheid niet vanzelfsprekend, ontbreekt het vaak aan intersectorale netwerken, zijn er geen krachtige sleutelfiguren om verbindingen te leggen, worden er geen gezamenlijke beleidsdoelen en concrete maatregelen geformuleerd en zijn de 'win-win' situaties onvoldoende helder voor betrokkenen (37). Om andere sectoren mee te krijgen in het verbeteren van de volksgezondheid, om te komen tot samenwerking en afstemming, zijn helderheid en overtuigingskracht onontbeerlijk. Overtuigingskracht kan ontleend worden aan bewijs van effectiviteit, zeker op lokaal niveau waar de politiek veel nadruk legt op korte termijn effecten. Maar het is moeilijk om de effectiviteit van integraal gezondheidsbeleid vast te stellen. Er is weinig kennis voorhanden over lokale intersectorale samenwerking en de effecten daarvan op het ontwikkelen van integraal beleid en het realiseren van gezondheidsdoelen (38). Veel kennis over effectieve maatregelen komt uit het buitenland en deze maatregelen zijn nog onvoldoende onderzocht voor de Nederlandse situatie $(29,35,39,40)$. Daarom is het belangrijk landelijk 'best-practices' met betrekking tot lokale intersectorale samenwerking en integraal gezondheidsbeleid te inventariseren. Dit kan het werken met integraal gezondheidsbeleid op lokaal niveau bevorderen.

Verschillende opvattingen over de totstandkoming van beleid

Er bestaan verschillende opvattingen over hoe beleidsprocessen doorlopen worden om te komen tot besluitvorming $(41,42)$. Aan de ene kant is er de analytisch-rationele opvatting over beleid volgens het zogenoemde Fasenmodel (43) (zie figuur 1.3). Hierbij wordt uitgegaan van een min of meer volgtijdelijk proces van de beschreven deelstappen en het van een beperkt aantal actoren dat het beleid bepaalt. Uiteraard kunnen externe invloeden, zoals media of belangengroepen, het beleidsproces wel beïnvloeden. Het proces begint met de agendasetting van een bepaald maatschappelijk probleem, daarna volgen de beleidsvoorbereiding of -ontwikkeling en de beleidsbepaling. Vervolgens wordt het beleid uitgevoerd en geëvalueerd op haar effecten. Indien na de beleidsevaluatie het bestaande beleid wordt aangepast of nieuw beleid wordt gevormd start het beleidsproces opnieuw (zie Figuur 1.3).

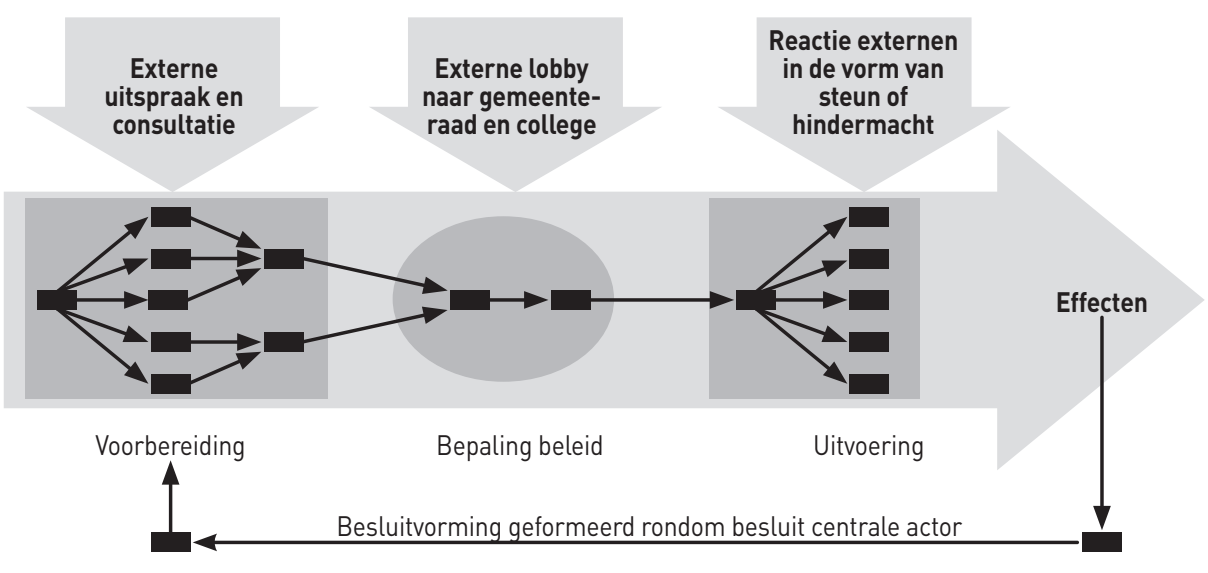

Figuur 1.3: Het Fasenmodel (41, 43)

Deze rationele beleidsopvatting stelt dat beleidsproblemen voortkomen uit een gebrek aan kennis en dat kennisbenutting leidt tot betere probleemoplossing. De nadruk wordt gelegd op kennis en het vermogen van mensen om hier rationeel en analytisch mee om te gaan. Maar als beleidsvoorbereiding en -bepaling het gevolg zijn van diverse activiteiten en (deel-)beslissingen van diverse actoren, zoals in de praktijk vaak het geval is, volstaat deze rationele opvatting over beleid niet. Een netwerk-contextuele opvatting is dan meer van toepassing, waarin gesteld wordt dat beleidsproblemen in verband staan met belangentegenstellingen en machtsverschillen. Alleen voldoende politieke wil bij actoren zal leiden tot voldoende draagvlak om problemen op te lossen. Vanuit deze opvatting over beleid wordt vaker het Stromenmodel $(44,45)$ (zie figuur 1.4) gebruikt.

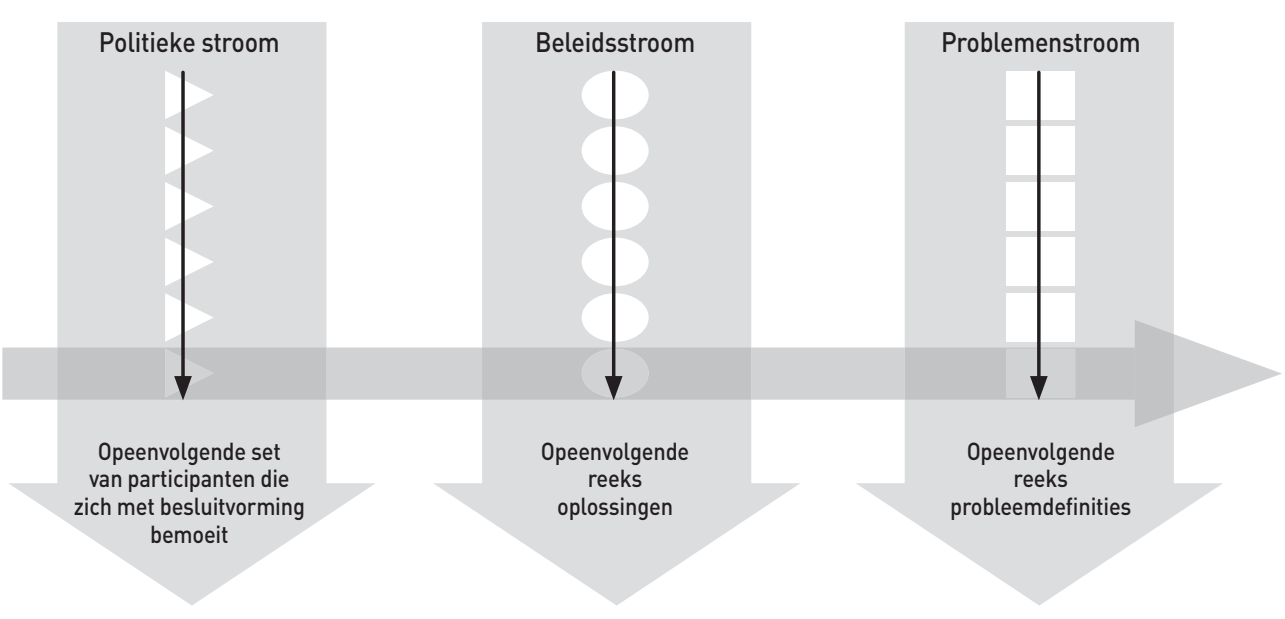

Figuur 1.4: Het stromenmodel (41, 44) 
De veronderstelling bij het Stromenmodel is dat drie stromen (politiek, beleid en problemen) gelijktijdig en voortdurend in beweging zijn. Majeure beleidswijzigingen treden op zodra de drie stromen, toevalligerwijs gekoppeld raken via een 'window of opportunity'. Koppeling tussen de drie stromen kan gestimuleerd worden door beleidsentrepreneurs, ook wel policy entrepreneurs' genoemd (46). Een entrepreneur is een persoon die actief probeert het beleidsproces te stimuleren door koppelingen te leggen tussen een probleem, mogelijke oplossingen en de politieke besluitvorming. Het Stromenmodel heeft sterke raakvlakken met het zogeheten Rondenmodel van Teisman (41). Het Rondenmodel kent evenmin een planmatige aanpak en gaat er vanuit dat een beleidsproces is opgebouwd uit een reeks beslissingen die door verschillende actoren worden genomen en dat oplossingen en problemen pas relevant zijn wanneer zi] door een belanghebbende (een beleidsentrepreneur) aan het beleidsproces naar voren worden gebracht. Essentieel binnen de netwerk-contextuele beleidsopvatting is het verkrijgen van een adequaat beeld van de aanwezige opvattingen over beleid en de macht van de relevante actoren, omdat dit de mate van consensus in een bepaalde politieke omgeving beïnvloedt (42). Voor het ontwikkelen van beleid is het belangrijk inzicht te verkrijgen in de manier waarop het beleidsproces binnen een bepaalde organisatie wordt doorlopen; meer rationeel en volgtijdelijk of meer incrementeel en zoekend naar kansen of via een mix van deze twee beleidsprocessen. Dit inzicht vergroot de mogelijkheden om het beleidsproces te beïnvloeden.

\subsection{Gemeentelijk integraal gezondheidsbeleid}

\section{Wet publieke gezondheid (Wpg)}

Werken aan publieke gezondheid is in Nederland een taak van de landelijke en lokale overheid. Een van de belangrijkste grondslagen hiervoor is de Wpg. Tot 1 december 2008 waren de taken en verantwoordelijkheden van gemeenten ten aanzien van collectieve preventie op het gebied van volksgezondheid vastgelegd in de Wet collectieve preventie volksgezondheid $(47,48)$. Sindsdien is de Wcpv overgegaan in de Wpg (3). Op basis van deze wet hebben gemeenten de bestuurlijke verantwoordelijkheid om de totstandkoming, continuïteit en samenhang binnen de publieke gezondheid te bevorderen. Zij hebben de taak om de gezondheid van hun inwoners te beschermen, te bewaken en te bevorderen. Naast de uitvoering van basistaken op het gebied van publieke gezondheid, infectieziektebestrijding en jeugdgezondheidszorg, moeten gemeenten ook zorgdragen voor intersectorale samenwerking en het verbinden van publieke gezondheid aan curatie. Sinds 2003 moeten gemeenten iedere vier jaar verantwoording afleggen en hun plannen beschrijven in een regionale en/of lokale nota gemeentelijk gezondheidsbeleid. In deze nota worden de gezondheidstoestand van de bevolking en de (integrale)beleidsdoelstellingen beschreven. Tevens wordt aangegeven hoe het beleid uitgevoerd gaat worden in de komende beleidsperiode. De verplichte basistaken laten gemeenten uitvoeren door GGD'en, waarvan zij eigenaar zijn. Bij de uitvoering van het totale gezondheidsbeleid spelen echter veel meer partijen - binnen en buiten de gemeentelijke organisatie - een rol. In het uitvoeringsproces met deze partijen hebben gemeenten vooral een regierol. Naar externe partijen toe is een gemeente soms ook opdrachtgever, partner en/of financier. Soms is de gemeente ook uitvoerder van het gezondheidsbeleid. De GGD ondersteunt en adviseert gemeenten bij de invulling van het gehele beleidsontwikkelings- en uitvoeringsproces.

Eens per vier jaar stelt de landelijke overheid beleidsprioriteiten vast op basis van de landelijke Volksgezondheid Toekomst Verkenning (VTV), die de kaders vormen voor het lokale gezondheidsbeleid van gemeenten. De Inspectie voor de Gezondheidszorg (IGZ) toetst het lokale gezondheidsbeleid en geeft daarmee input voor koerswijzigingen, zowel landelijk als lokaal (49). Deze vierjarige preventiecyclus is de basis voor het Nederlandse volksgezondheidsbeleid (zie figuur 1.5)

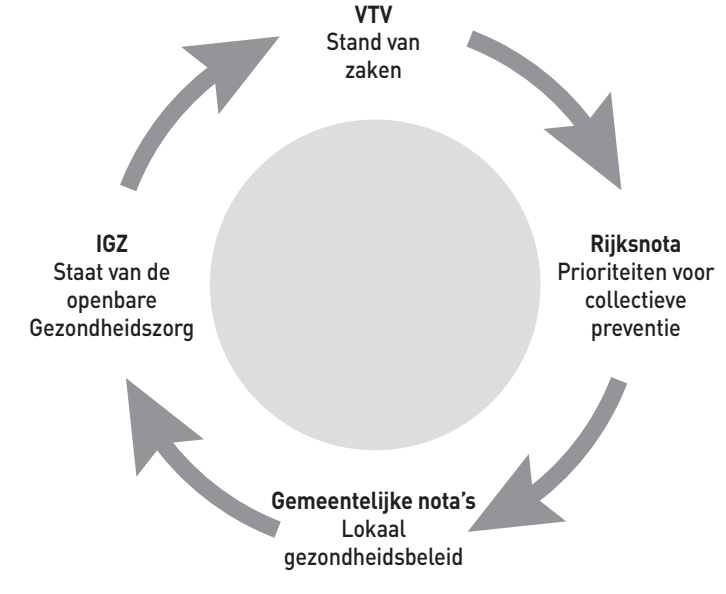

Figuur 1.5: De vierjarige Nederlandse preventiecyclus (50)
In 2005 constateerde de IGZ dat er binnen gemeenten in Nederland weliswaar een toename van de bestuurlijke betrokkenheid bij preventief gezondheidsbeleid waarneembaar is, maar dat nog onvoldoende sprake is van sturing. Volgens de IGZ komen de rollen van regisseur en financier van publieke gezondheid niet genoeg uit de verf, doordat het beleid niet consistent en de uitvoering onzeker is. Gemeenten ervaren vooral gebrek aan geld, ambtelijke capaciteit, directe bevoegdheden en politieke urgentie om lokaal gezondheidsbeleid vorm te geven en uit te voeren $(51,52)$. Sinds 2005 is er veel gebeurd om de effectiviteit van het lokale gezondheidsbeleid te verbeteren en veel GGD'en voorzien hun gemeenten adequater van gezondheidsinformatie Maar volgens de inspectie zijn er ook nog veel zaken die verbeterd kunnen worden. Zo zijn de preventieve beleidsdoelstellingen in de gemeentelijke nota's nog steeds weinig SMART' ${ }^{1}$ formuleerd en ontbreekt het vaak aan een gedegen uitvoeringsplan, worden bestuurlijke besluiten niet systematisch getoetst op gevolgen voor de volksgezondheid, vragen gemeenten zelden advies aan hun GGD en is er onvoldoende sprake van integraal gezondheidsbeleid $(30,53,54)$. Hoewel de aandacht voor integraal gezondheidsbeleid is toegenomen in de tweede ronde van lokale nota's 2007-2011 (55), is het voor gemeenten niet eenvoudig om inhoud en vorm te geven

1 SMART staat voor: Specifiek, Meetbaar, Acceptabel, Realistisch en Tijdgebonden 
aan integraal gezondheidsbeleid. Het blijkt lastig om andere sectoren te betrekken bij gezondheid, verbindingen te leggen tussen problemen, oplossingen en verschillende sectoren, of zorg te dragen voor een continue structurele aanpak (33). Dit terwijl gemeenten een scala aan beleidsinstrumenten ter beschikking hebben om de gezondheid van haar burgers te bevorderen. Wettelijke instrumenten, zoals de Wpg en de Wmo, en economische instrumenten, zoals subsidieverstrekkingen, kunnen naast 'zachtere' beleidsinstrumenten, zoals convenanten, voorlichting en overleg, in elkaars verlengde worden ingezet $(49,56)$. Daarnaast kan gedach worden aan bijvoorbeeld pleitbezorging en media-aandacht waarmee publieke en politieke druk kan worden uitgeoefend.

Op basis van landelijk beschikbare gezondheidsgegevens brengt het RIVM elke vier jaar de Volksgezondheid Toekomst Verkenning (VTV) uit $(21,57)$. Om de politieke urgentie van het gezondheidsbeleid te verhogen brengen veel GGD-en in Nederland sinds kort voor hun gemeenten een regionale VTV uit waarin een regionaal beeld wordt geschetst van de gezondheidssituatie. Hiermee ondersteunt een GGD haar gemeenten bij het ontwikkelen van regionaal of lokaal gezondheidsbeleid $(28,58,59)$. In de regio Zuid-Limburg hebben bijvoorbeeld de gemeenten en hun GGD in 2007 voor het eerst gezamenlijk een regionale prioriteitennota vastgesteld waaraan vervolgens elke gemeente een eigen lokale nota heeft gekoppeld. In het verlengde daarvan is in 2011 op basis van een regionale Volksgezondheid Toekomst Verkenning voor alle gemeenten één regionale nota gezondheidsbeleid Zuid-Limburg 2012-2015 vastgesteld waaraan elke Zuid-Limburgse gemeente een eigen uitvoeringsprogramma heeft gekoppeld. Gezondheid is door deze regionale prioritering nadrukkelijker op de lokale beleidsagenda geplaatst. Dit sluit aan bij de landelijke visie 'Gezondheid dichtbij' (4) waarin het ministerie van VWS nadrukkelijk aangeeft dat gemeenten als eerste aan zet zijn als een bijdrage van de overheid noodzakelijk is op het vlak van de publieke gezondheid. In deze landelijke nota wordt gezondheidsbevordering niet aangemerkt als nationale, maar als een lokale prioriteit, en krijgt gezondheidsbescherming de eerste prioriteit.

1.4 Nieuwe kansen voor gemeentelijk integraal gezondheidsbeleid

\section{Kansen vanuit de Wpg}

Op 18 mei 2011 is de gewijzigde Wpg vastgesteld (de zogenaamde Wpg 2e tranche) (60). In 2010 heeft het kabinet geconstateerd dat de preventiecyclus (de vierjarige beleidscyclus die wordt gebruikt als basis voor het Nederlandse gezondheidsbeleid, zie figuur 1.6) op lokaal niveau onvoldoende functioneert. Gemeenten volstaan in hun lokale nota's te vaak met algemene intenties; het lokale gezondheidsbeleid leeft onvoldoende (54). Daarom is in 2011 een aanpassing van de Wpg in werking getreden. Vanaf 1 oktober 2011 dienen gemeenten de landelijke prioriteiten, zoals opgenomen in de landelijke nota gezondheidsbeleid, in acht te nemen. Gemeenten hebben de vrijheid om gemotiveerd af te wijken van de landelijke prioriteiten, op basis van bijvoorbeeld lokale epidemiologische gegevens, mits ze dit in de nota onderbouwen. Voor de lokale nota's gelden voortaan vormvoorschriften. De nota moet in ieder geval vermelden wat de gemeentelijke doelstellingen zijn, welke acties worden ondernomen om deze doelen te halen en welke resultaten de gemeente in die periode wenst te realiseren. De vormvoorschriften dienen in de visie van het kabinet als prikkel voor gemeenten om de beleidsvoornemens in de nota's gemeentelijk gezondheidsbeleid concreter te formuleren en daarmee de dynamiek en het debat op lokaal niveau te bevorderen. Tevens geven de vormvoorschriften gemeenteraden goede handvatten om het gevoerde gezondheidsbeleid te kunnen evalueren, hetgeen het lokale beleidsproces kan stimuleren (61)

\section{Kansen vanuit de Wmo}

Op 1 januari 2007 trad de Wmo in werking. Deze wet heeft een aantal maatschappelijke doelstellingen, namelijk het bevorderen van de zelfredzaamheid van burgers met een beperking, he stimuleren van de (maatschappelijke) participatie van burgers en het versterken van de sociale samenhang en leefbaarheid op lokaal niveau. De beleidsregie voor deze wet ligt bij gemeenten, maar is wel landelijk ingekaderd via negen prestatievelden (zie tabel 1.2).

Inhoudelijk gezien zijn er duidelijke raakvlakken tussen de Wmo en de Wpg (62). Participatie aan het maatschappelijk leven en gezondheid kunnen immers niet los van elkaar worden gezien Gemeenten spelen zowel aan het begin van de preventiezorgketen (het voorkomen van ziekte door middel van universele en selectieve preventie) als aan het einde van de keten (verstrekking van (zorg)voorzieningen ten behoeve van maatschappelijke participatie) een belangrijke rol (zie Figuur 1.6). Ook dragen gemeenten zorg voor kwetsbare doelgroepen die buiten de boot dreigen te vallen en wordt ketensamenwerking rondom multiproblematiek (werkloos, dakloos en verslaafd) gestimuleerd. Preventie verbindt de sectoren van publieke gezondheid, welzijn, curatie en zorg, want elke sector heeft een vorm van preventie in zich.

De afstemming tussen preventie en zorg wordt voor gemeenten steeds noodzakelijker. De Wmo is een brede wet die gemeenten mogelijkheden biedt om preventie en zorg in samenhang met beleidssectoren zoals wonen, ruimtelijke ordening, integratiebeleid, veiligheid en economie beter op elkaar af te stemmen $(25,63)$. De Wmo biedt daarom bij uitstek veel mogelijkheden voor integraal beleid. Echter, bij de start van de implementatie van de Wmo verliep de lokale concretisering bij veel gemeenten moeizaam (66). Niet alle prestatievelden van de Wmo kregen evenveel prioriteit en het accent werd vaak vooral gelegd op zorg (hulp bij het huishouden en vervoersvoorzieningen) en in mindere mate op preventie (opvoedingsondersteuning en steun aan mantelzorgers). Het Sociaal en Cultureel Planbureau stelt in 2010 dat de meeste gemeen- 


\section{De negen prestatievelden van de Wmo:}

Het bevorderen van de sociale samenhang in en leefbaarheid van dorpen, wijken en buurten.

2 Op preventie gerichte ondersteuning van jeugdigen met problemen met opgroeien en van ouders met problemen met opvoeden.

3 Het geven van informatie, advies en cliëntondersteuning

$4 \quad$ Het ondersteunen van mantelzorgers en vrijwilligers.

$5 \quad$ Het bevorderen van de deelname aan het maatschappelijke verkeer en van het zelfstandig functioneren van mensen met een beperking of een chronisch psychisch probleem en van mensen met een psycho-sociaal probleem.

$6 \quad$ Het verlenen van voorzieningen aan mensen met een beperking of een chronisch psychisch probleem en aan mensen met een psycho-sociaal probleem ten behoeve van het behoud van hun zelfstandig functioneren of hun deelname aan het maatschappelijke verkeer

$7 \quad$ Het bieden van maatschappelijke opvang, waaronder vrouwenopvang.

$8 \quad$ Het bevorderen van openbare geestelijke gezondheidszorg, met uitzondering van het bieden van psycho-sociale hulp bij rampen.

$9 \quad$ Het bevorderen van verslavingsbeleid

ten de Wmo uitvoeren zoals de wetgever dat heeft bedoeld en dat het merendeel van de gemeenten heeft gekozen voor een invulling van de Wmo conform de prestatievelden, met ook aandacht voor sociale samenhang en kwetsbare burgers. Maar tegelijkertijd wordt ook aangegeven dat het Wmo beleid binnen gemeenten nog volop in ontwikkeling is en dat inhoudelijke doorontwikkeling van de verschillende Wmo prestatievelden een uitdaging is voor de toekomst (67).

\section{Kansen door decentralisatie van zorgtaken}

De Nederlandse rijksoverheid decentraliseert steeds meer wettelijke verantwoordelijkheden op het gebied van gezondheid, zorg en welzijn naar de gemeenten en in het verlengde daarvan de GGD. De overheid wil hiermee gemeenten meer armslag en verantwoordelijkheden geven ter vergroting van de bestuurlijke effectiviteit. Gemeenten staan dichter bij de bevolking en kunnen het beleid daardoor beter afstemmen op lokale behoeften en mogelijkheden. Deze decentralisering van zorgtaken heeft tot gevolg dat gemeenten steeds meer verantwoordelijkheden krijgen, namelijk niet alleen voor de Wpg (3) maar met ingang van 2007 ook voor de Wmo en sinds

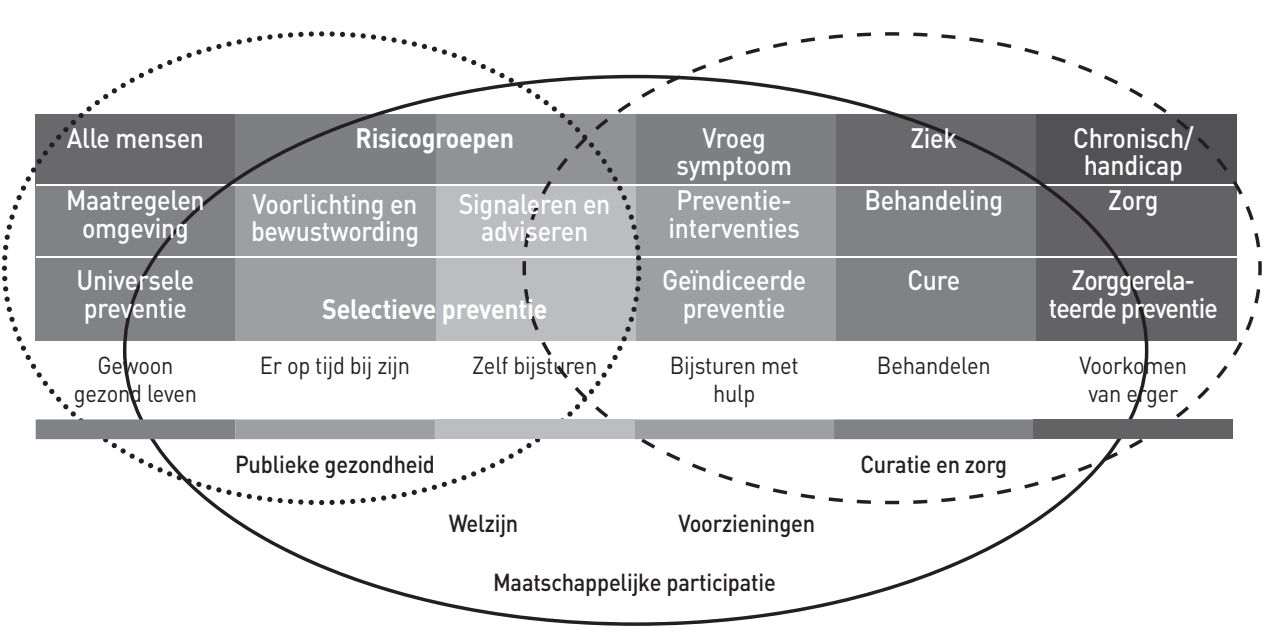

Figuur 1.6: Geïntegreerd model voor gezondheid en welzijn 164,65 ,

2008 voor de Centra voor Jeugd en Gezin (CJG). Tevens zijn er plannen om gemeenten in 2014 bestuurlijk verantwoordelijk te maken voor de jeugdzorg. Door deze decentralisatie van zorg taken groeit de gemeentelijke interesse voor de kracht van preventie. Gemeenten willen voorkómen of zo lang mogelijk uitstellen dat burgers niet volwaardig kunnen deelnemen aan de maatschappij. Om dit te kunnen realiseren is het belangrijk om preventief gezondheidsbeleid nadrukkelijker te verbinden met andere gemeentelijke beleidsterreinen. Maar dit kan niet los worden gezien van het belang van ondersteunende en sluitende zorgnetwerken én een gezonde leefomgeving rondom een individu.

In de toekomst zal er meer geïnvesteerd moeten worden aan de voorkant om de gezondheidszorgkosten binnen de perken te kunnen houden. Hiervoor is samenwerking en afstemming tussen preventieve gezondheidszorg en curatieve zorg essentieel. Meer aandacht voor een leefomgeving met aandacht voor gezondheid en gedrag (GG) in plaats van zorg en ziekte (ZZ) (68). Gemeenten en zorgverzekeraars zouden integraal gezondheidsbeleid hoger op de beleidsagenda moeten plaatsen. Decentralisatie van wettelijke zorgtaken biedt gemeenten de mogelijkheid to regievoering voor het ontwikkelen van integraal (gezondheids)beleid, in lokaal en/of regionaal verband, en in het verlengde daarvan tot het bewerkstelligen van lokaal maatwerk $(69,70)$ 


\subsection{Noodzaak tot samenwerking}

In de landelijke nota gezondheidsbeleid 'Gezondheid dichtbij' pleit het ministerie van VWS voor gedeelde verantwoordelijkheid van het bedrijfsleven, maatschappelijke organisaties, het onderwijs en zorgverleners om te blijven investeren in het behouden en verbeteren van de volksgezondheid (4). Gemeenten krijgen een nadrukkelijke rol toebedeeld om zorg en sport dicht bij de burgers te stimuleren en indien nodig te faciliteren. Publiek-private samenwerking wordt gezien als een kansrijke methode om de gezonde keuzes aantrekkelijk en toegankelijk te maken. En gemeenten worden gestimuleerd om op zoek te gaan naar lokale mogelijkheden en kansen om integraal gezondheidsbeleid vorm te geven (4). Kortom, hier ligt een duidelijke taakstelling voor gemeenten tot integraal gezondheidsbeleid.

\section{Beperkte prikkels voor preventie}

Preventie van ongezondheid is lange tijd een zaak geweest van bescherming tegen infectieziekten, ongevallen, zuigelingen- en kindersterfte, ondervoeding, risicovolle huisvesting en arbeidscondities en armoede. Sinds enige decennia wordt ook gewerkt aan de preventie van schade door ongezonde leefgewoonten die samenhangen met welvaartsziekten, zoals roken, te veel eten en excessief alcoholgebruik. De maatschappelijke waardering van welvaart is hoog en in het Nederlandse gezondheidsbeleid ligt veelal de nadruk op eigen verantwoordelijkheid $(4,61)$. Individuen laten zich ook niet gemakkelijk aanspreken op hun leefstijl. Reeds in 2002 werd door de Raad voor de Volksgezondheid en Zorg (RVZ) de slogan gelanceerd 'stimuleer gezond gedrag door de gezonde keuze gemakkelijker te maken' waarbij de gezonde keuze niet alleen werd gezien als een verantwoordelijkheid van de individuele burger, maar ook als een verantwoordelijkheid van de lokale overheid, maatschappelijke partijen en niet in de laatste plaats de zorgverzekeraars. Echter, de ontwikkeling naar een zorgstelsel met gereguleerde marktwerking is tot nu toe niet bevorderlijk geweest voor preventie. Zorgprofessionals worden betaald voor reparatie van ontstane gezondheidsschade en niet voor het voorkómen van nieuwe schade (61). Omdat de effecten van preventie pas op lange termijn zichtbaar worden, is het vanuit het korte termijn perspectief van zorgverzekeraars niet interessant om hierin te investeren. Bovendien zijn er tot nu toe nauwelijks prikkels vanuit de overheid aan zorgverzekeraars gegeven om gezond gedrag te stimuleren. Zorgverzekeraars zouden bijvoorbeeld kunnen voorzien in incentives voor individuele burgers die gezond gedrag vertonen, bijvoorbeeld als ze lid worden van een sportclub om zo medicatiegebruik terug te dringen. Dit gebeurt echter nauwelijks.

Wat betreft de rol van de lokale overheid geldt eveneens dat er weinig prikkels zijn om te investeren in preventie. De kosten komen ten laste van de gemeenten, en de revenuen - in termen van gezondheidswinst - komen in eerste instantie ten goede aan de zorgverzekeraars en natuurlijk aan de betrokken individuen. Gezondheidswinst op individueel niveau vertaalt zich in een termijn van
4 jaar (de gebruikelijke periode tussen 2 gemeenteraadsverkiezingen) dus niet in financieel zichtbare resultaten op het collectieve niveau voor gemeenten. Voor de (lokale) overheid is het bovendien lastig om preventie vorm te geven, bijvoorbeeld alleen al omdat hiervoor de medewerking nodig is van andere sectoren, zoals het bedrijfsleven en de lokale middenstand waar andere belangen een hogere prioriteit hebben dan gezondheid. Toch zijn bijvoorbeeld vanuit het oogpunt van besparingen in de Wmo-voorzieningen of het verkleinen van sociaal-economische gezondheidsverschillen preventieve interventies zeker interessant voor gemeenten. Zo is het project De Gezonde Wijk Overvecht van de gemeente Utrecht en haar GGD een goed voorbeeld van gemeentelijke preventief beleid dat door samenwerking met een zorgverzekeraar een batig saldo op de zorgkosten heeft opgeleverd van $4 \%(61,71)$.

\section{Complexe gezondheidsproblemen}

Veel van de huidige maatschappelijke problemen zijn complex waardoor deze moeilijk zijn aan te pakken en daarom ook wel 'wicked problems' worden genoemd (72). Dergelijke problemen zijn moeilijk onderzoeksmatig in te kaderen en te analyseren omdat het vaak ontbreekt aan kennis over mogelijke causale relaties en over een geschikte aanpak. Een ultieme aanpak is er niet. Elke gekozen aanpak heeft consequenties welke weer gezien kunnen worden als een nieuw probleem. Daarnaast zijn er veel actoren betrokken en dienen er met beperkte kennis beslissingen genomen te worden binnen verschillende beleidsnetwerken $(72,73)$. Om dergelijke complexe problemen te kunnen oplossen is het enerzijds belangrijk een zo adequaat mogelijk antwoord te formuleren en anderzijds noodzakelijk voldoende steun en draagvlak voor de gekozen oplossing te verwerven $(28,42)$. Veel gezondheidsproblemen zijn 'wicked problems', hetgeen invloed heeft op de ontwerpstrategie die wordt toegepast om beleid te ontwikkelen en te werken aan oplossingen (zie Tabel 1.3).

\section{Tabel 1.3: Relatie tussen probleem en keuze van ontwerpstrategie (42)}

\begin{tabular}{lll}
$\begin{array}{l}\text { Zeker probleem / } \\
\text { veel kennis }\end{array}$ & $\begin{array}{l}\text { Eenvoudig probleem } \\
\text { ontwinematige } \\
\text { ontwstrategie }\end{array}$ & $\begin{array}{l}\text { Domplex probleem } \\
\text { ontwostische }\end{array}$ \\
\hline $\begin{array}{l}\text { Onzeker probleem / } \\
\text { weinig kennis }\end{array}$ & $\begin{array}{l}\text { Intuïtieve } \\
\text { ontwerpstrategie }\end{array}$ & $\begin{array}{l}\text { Lerende } \\
\text { ontwerpstrategie }\end{array}$ \\
\hline
\end{tabular}

Als het om een relatief beperkt en eenvoudig gezondheidsprobleem gaat waarvan de oorzaken of de aanpak vrij zeker zijn, is een routinematige ontwerpstrategie geschikt, denk bijvoorbeeld aan hoofdluis bij kinderen waar via hygiënemaatregelen in het gezin en op school snel resultaa kan worden gerealiseerd. Een diagnostische ontwerpstrategie is geschikt voor relatief grote en complexe gezondheidsproblemen waarvan de oorzaken of de aanpak vrij zeker zijn, denk 
bijvoorbeeld aan het probleem van besmettelijke kinderziekten waar gezondheidsrisico's via vaccinaties worden gereduceerd. Bij een relatief beperkt en eenvoudig gezondheidsprobleem waarvan de oorzaken of de aanpak met veel onzekerheden omgeven zijn, zoals bijvoorbeeld schoolverzuim bij jeugdigen, is een intuïtieve ontwerpstrategie lop basis van intuïtie en ervaringskennis) meer geschikt. Terwijl complexe gezondheidsproblemen, zoals overgewicht, moeilijk zijn aan te sturen omdat er veel onzekerheid is over de mogelijke gezondheidsrisico's, de inzetbare effectieve interventies én omdat er een groot en divers aantal actoren nodig is bij de aanpak van het gezondheidsprobleem. Een lerende ontwerpstrategie is dan meer van toepassing. Kenmerkend van een dergelijk ontwerpstrategie is dat vorming en uitvoering van beleid (groten)deels gelijktijdig plaatsvinden én tot stand komen door middel van een proces van 'trial and error'. Daarbij telt iedere 'trial' mee en heeft invloed op het vervolg, want ook een 'error' beïnvloedt het proces. Deze lerende ontwerpstrategie biedt bij uitstek mogelijkheden om integraal gezondheidsbeleid te ontwikkelen.

\section{Gemeentelijke intersectorale samenwerking}

Binnen gemeenten is de beleidsportefeuille volksgezondheid (VGZ) ondergebracht bij afdelingen met diverse benamingen, zoals Breed Welzijn, Maatschappelijke Ondersteuning, Burger en Bestuur of Maatschappij en Ruimte. Deze gemeentelijke beleidsafdelingen hebben een breed takenpakket waar meerdere inhoudelijke taakvelden zijn ondergebracht zoals onderwijs, cultuur, welzijn en sport (74). De positionering van de beleidsportefeuille VGZ binnen dergelijke brede afdelingen biedt mogelijkheden tot intersectorale samenwerking en integraal gezondheidsbeleid $(22,75,76)$. Maar om intersectorale samenwerking binnen een gemeente to stand te brengen dienen actoren op strategisch (bestuurders/portefeuillehouders), tactisch (managers/afdelingshoofden) en operationeel (beleidsmedewerkers) niveau zowel functioneel (horizontaal) als hiërarchisch (verticaal) met elkaar in overleg te treden. Dit dient ook nog eens plaats te vinden binnen een beleidsterrein (verticale samenwerking) én per niveau tussen verschillende gemeentelijke beleidsterreinen (horizontale samenwerking) (zie Figuur 1.7) (77).

Het is dus belangrijk dat er een continue (in)formele interactie tussen verschillende beleidsterreinen en op de drie functieniveaus wordt gestimuleerd $(20,77,78)$. Door horizontaal en verticaal meer en anders te gaan samenwerken kunnen geleidelijk aan grenzen tussen beleidssectoren opschuiven en vervagen. Vanuit de theorie wordt dit omschreven als blurring the boundaries' door bijvoorbeeld frequenter, in een vroeger stadium in het beleidsproces en zonder waardeoordelen met elkaar te overleggen. Ook door 'institutional re-design', het veranderen van werkafspraken en regels, kan de onderlinge samenwerking tussen verschillende beleidssectoren binnen een organisatie worden vergroot. Bijvoorbeeld door posities van actoren te veranderen of te versterken, of andere afspraken te maken over de prestatie-indicatoren die gehanteerd worden in het beleidsproces (78).
Verticale samenwerking:
hiërarchisch

Strategisch niveau:
portefeuillehouder VGZ
Tactisch niveau:
manager/afdelingshoofd VGZ
Operationeel niveau:
beleidsmedewerker VGZ

Horizontale

samenwerking:
functioneel
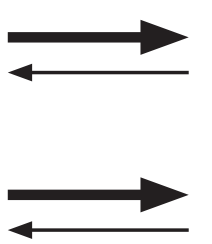

$\longleftarrow$

$\longleftarrow$
Verticale samenwerking:
hiërarchisch

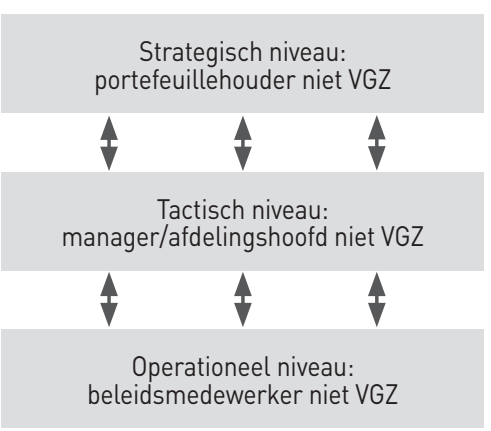

Figuur 1.7: Gemeentelijke intersectorale verticale en horizontale samenwerking (77)

Nederlandse adviesraden hebben geconcludeerd dat nationale en lokale overheden via intersectorale samenwerking veel gezondheidswinst kunnen realiseren (29). Maar gemeentelijke beleidsafdelingen werken niet vanzelfsprekend samen. De verschillende beleidsafdelingen binnen een gemeentelijke organisatie zijn in feite te vergelijken met niches, oftewel op zichzelf staande eenheden met een eigen werkcultuur, doelen en middelen, met als doel zichzelf in stand te houden. $\mathrm{Er}$ is sprake van 'verkokering' (alleen verticale samenwerking) en vaak ontbreekt een 'interface' (verbinding/koppeling) tussen de medewerkers van verschillende beleidsafdelingen (horizontale samenwerking) (77). Het blijkt dat managers van afdelingen waarbinnen VGZ is opgenomen zich vooral hiërarchisch verantwoordelijk voelen voor hun afdeling en het beheer ervan zorgvuldig bewaken, maar dat zij slechts beperkt inhoudelijk betrokken zijn (79). Veel beleidsmedewerkers VGZ hebben naast de portefeuille VGZ ook de Wmo in hun takenpakket waardoor zij inhoudelijke verbindingen juist kunnen stimuleren. Maar in de praktijk blijkt dit laatste maar weinig te gebeuren en hebben gemeenten weinig tot geen beleidscapaciteit beschikbaar voor het beleidsterrein VGZ, zeker in vergelijking met de beschikbare capaciteit voor de Wmo en de totale beleidsafdeling waarbinnen VGZ is gepositioneerd (79). Hierdoor blijft volksgezondheid vaak de sluitpost van de beschikbare beleidscapaciteit binnen een gemeente.

De gemiddelde burger neemt de meeste informatie over publieke zaken via de media tot zich. De taal die de media gebruikt, beïnvloedt de manier waarop we naar de werkelijkheid kijken. Zo roept de gebruikte taal bepaalde associaties op en beïnvloedt het ons normatieve oordeel. We oordelen anders over een 'meldpunt' dan over een 'kliklijn' en klinkt 'genetisch gemodificeerd' voedsel anders dan 'genetisch gemanipuleerd' voedsel (80). Hierdoor worden beelden, beoordelingen en verwachtingen gecreëerd over welke publieke zaken relevant of minder relevant 
zijn. Op deze wijze ontstaan dominante of minder dominante 'frames' (81). Gemeenten zien volksgezondheid van oudsher niet als een dominant 'policy frame' maar meer als een landelijk opgelegde taakstelling die ze zo 'low profile' mogelijk willen afhandelen (82). In de taal van de beleidsmakers komt het woord volksgezondheid maar zeer beperkt voor. Alleen bij actuele bedreigingen van de sociale veiligheid, zoals bijvoorbeeld bij een chemische brand of Q-koorts, krijgt de publieke gezondheid in de politiek tijdelijk opeens de volle aandacht. Ook vinden gemeenten het niet altijd makkelijk maatregelen voor publieke gezondheid maatschappelijk te legitimeren. Legitimiteit heeft te maken met de aanvaardbaarheid en zichtbaarheid van het beleid door de burgers rondom een bepaalde maatschappelijke situatie. Er is beperkt draagvlak bij burgers als een gemeente beleid ontwikkelt op het terrein van leefstijlinterventies omdat deze de persoonlijke levenssfeer kunnen raken $(82,83)$. Het bevorderen van de volksgezondheid (de Wpg) is voor gemeenten geen uitdagend 'policy frame'. Vaak zie je dan ook dat de ambtenaar VGZ na een relatief korte tijdsperiode overstapt naar een ander beleidsterrein, zoals de Wmo. Dergelijke ambtelijke discontinuïteit maakt het niet gemakkelijk gemeentelijke intersectorale samenwerking te realiseren $(74,84)$.

\subsection{Gemeentelijke afdeling VGZ: de GGD}

\section{Kenmerken van een Gemeentelijke GezondheidsDienst (GGD)}

Een gemeentelijke gezondheidsdienst (GGD) onderscheidt zich van andere organisaties in de reguliere gezondheidszorg door haar unieke plaats in het openbaar bestuur en de specifieke wijze waarop de organisatie wordt bestuurd. Vanuit de wet $(3,47,48)$ zijn gemeenten wettelijk verplicht een GGD in stand te houden en tevens bestuurlijk eindverantwoordelijk voor de volksgezondheid in hun werkgebied. Beide organisaties zijn sterk aan elkaar verbonden. Concreet betekent dit dat:

a. een GGD valt onder de bestuurlijke verantwoordelijkheid van gemeenten en gezien kan worden als verlengd lokaal bestuur:

b. gemeenten via de Wpg wettelijke taken opgelegd krijgen die zij via een GGD dienen uit te voeren;

c. gemeenten de beleidsregie hebben en een GGD in opdracht van gemeenten ondersteunend diensten uitvoert.

Een GGD is een dienst die de volksgezondheid probeert te verbeteren, met extra aandacht voor gezondheidsrisico's bij de mens en in zijn fysieke en sociale omgeving. De GGD treedt acuut op bij spoedeisende, medische hulpverlening en calamiteiten en bewaakt de veiligheid mee. Een GGD wordt volledig gefinancierd uit overheidsgelden. Gemeenten betalen een bedrag per inwoner voor de uitvoering van het volksgezondheidsbeleid, de zorgverzekeraar financiert de uitvoering van de acute zorgverlening. Gemeentelijke bestuurders met volksgezondheid in hun portefeuille hebben zitting in het dagelijks bestuur (DB) en het algemene bestuur (AB) van een GGD. GGD'en in Nederland kennen verschillende bestuursstructuren (85):

\section{1. een gemeentelijke GGD:}

een GGD opgericht bij besluit van één gemeente, waarbij is bepaald dat de GGD uitsluitend aan diezelfde gemeente zijn diensten verleent,

2. een gemeentelijke GGD met een regiofunctie via een gemeenschappelijke regeling:

een GGD, opgericht bij besluit van één gemeente, waarbij de GGD ook aan andere gemeenten op basis van een gemeenschappelijke regeling (GR) diensten verleent,

3. een regio-GGD op basis van een regionale gemeenschappelijke regeling:

een GGD, opgericht op basis van een regionale gemeenschappelijke regeling die de samenwerking tussen een aantal gemeenten en een GGD regelt.

Een gemeenschappelijke regeling (GR) is een wettelijke grondslag waarin het samenwerkingsverband tussen gemeenten en hun GGD wordt geregeld. In deze regeling wordt aangegeven hoe het bestuur is samengesteld en hoe besluitvorming tot stand komt (meerderheid van stemmen, stemverhoudingen etc.) en op welke wijze de noodzakelijke financiële middelen doorberekend worden naar gemeenten. Gemeenteraden van de betrokken gemeenten beslissen over oprichting, wijziging en heffing van een GR en wijzen een afvaardiging aan voor het $A B$ die een informatie- en verantwoordingsplicht heeft naar de raad. Gemeenteraden worden geïnformeerd over begroting en jaarrekening en de raad kan haar zienswijze geven op de begroting. Besluiten worden vervolgens genomen in het $A B$ van de GGD. Binnen gemeenten wordt soms kritisch aangekeken tegen een regionale GR vanwege het beperkte democratische gehalte van een dergelijk samenwerkingsverband.

\section{Wettelijke taken}

In de Wpg worden acht taakvelden onderscheiden, namelijk infectieziektebestrijding, jeugdgezondheidszorg, medische milieukunde, technische hygiënezorg, psychosociale hulp bij ongevallen en rampen, epidemiologie, gezondheidsbevordering en ouderengezondheidszorg. Grofweg kunnen de wettelijke taken verdeeld worden in twee hoofdgroepen: de medisch georiënteerde taken met een grote centrale sturing en de maatschappelijk georiënteerde taken met een grote lokale sturing. De medisch georiënteerde zorg (zoals bijvoorbeeld infectieziektebestrijding en technische hygiëne zorgl kent een sterke centrale sturing vanuit de rijksoverheid. In aan de wetgeving gekoppelde uitvoeringsbesluiten is nauwgezet vastgelegd hoe deze zorg moet worden ingevuld. Gemeenten hebben een beperkte beleidsvrijheid en zijn vooral uitvoerder van beleid. In de maatschappelijk georiënteerde zorg (zoals bij gezondheidsbevordering en ouderenge- 
zondheidszorg) is de beleidsvrijheid voor gemeenten groter. Hoewel er landelijk kaders worden gesteld aan de invulling van deze taken, kunnen gemeenten hier in veel grotere mate eigen keuzes maken. Voor de uitvoering van de hierboven beschreven wettelijke taken hebben gemeenten - via een GR - een GGD, waarvan zij eigenaar zijn. De toetsing op een adequate uitvoering van wettelijke taken is door de IGZ vormgegeven. Het ministerie van VWS vindt opschaling van de publieke gezondheidszorg naar het zogenaamde 1-1-5-25-model gewenst. Dit betekent dat het ministerie van VWS met één inhoudelijk kenniscentrum (RIVM) en één aanspreekpunt voor GGD'en (GGD Nederland) samenwerkt en in het verlengde daarvan met 5 veiligheidsregio's en 25 GGD'en. Per 1 juli 2009 beschikten de 441 gemeenten in Nederland over 28 GGD'en, in 1998 waren dit nog 54 GGD'en. Op 17 mei 2011 heeft de Eerste kamer besloten dat het aantal GGD'en van 28 teruggebracht moet worden naar 25 , qua geografie en aantal hetzelfde als de huidige veiligheidsregio's van de GHOR (Geneeskundige Hulpverlening bij Ongevallen en Rampen).

\section{Opdrachtgever en opdrachtnemer}

Gemeenten vervullen twee verschillende rollen voor hun GGD: enerzijds is de gemeente eigenaar en bestuurder van de GGD en anderzijds ook de belangrijkste klant en afnemer van de diensten van de GGD. Als vertegenwoordiger van de gemeente dient de portefeuillehouder VGZ enerzijds zorg te dragen voor een goede bedrijfsvoering en het meerjarenbeleid van de GGD en anderzijds voor de gemeente zo efficiënt en goedkoop mogelijk dienstverlening bij de GGD in te kopen. Tussen deze beide rollen kan spanning ontstaan.

Voor gemeenten is de GGD hun gemeentelijke beleidsadviseur en de belangrijkste uitvoerder van publieke gezondheidstaken. De beleidsadvisering dient volgens de Wpg gericht te zijn op het gevraagd en ongevraagd adviseren van gemeenten bij bestuurlijke beslissingen en het bewaken van de gezondheidsaspecten daarbinnen. De praktijk laat zien dat de GGD momenteel vrijwel uitsluitend op verzoek van de gemeenten adviseert. Van een proactieve rol in de zin van ongevraagde advisering is onvoldoende sprake, ondanks het feit dat de GGD zichzelf beschouwt als een expertise-centrum op het brede terrein van de publieke gezondheidszorg $(30,86,87)$. Veel gemeenten zien hun GGD in eerste instantie als een uitvoerende taakorganisatie $(52,85)$ Maar voor een adequate invulling van het volksgezondheidsbeleid dient de samenwerking tussen gemeenten en GGD méér te zijn dan puur de inkoop van dienstverlening bij de GGD. Het complexe beleidsveld van de publieke gezondheidszorg vraagt om een brede visie op het lokale gezondheidsbeleid en het ontwikkelen van integraal volksgezondheidsbeleid. In de ogen van de gemeente behoort hun beleidsmedewerker VGZ de expertise te bezitten om het regionale en lokale gezondheidsbeleid te ontwikkelen. De wijziging van de Wcpv in 2003 heeft deze opvatting versterkt, gemeenten kregen formeel de beleidsregie toegewezen en de opdrach vierjaarlijks beleid te ontwikkelen. Maar in de praktijk is er weinig formatie en expertise binnen gemeenten beschikbaar voor de beleidsportefeuille VGZ.

\section{Politieke keuze}

Voor de ontwikkeling van gemeentelijk integraal gezondheidsbeleid is het belangrijk dat er met name in de eerste twee stappen van het beleidsproces - agendasetting en beleidsvoorbereiding samenwerking en afstemming met andere gemeentelijke beleidsterreinen inclusief de GGD plaatsvindt (zie paragraaf 1.3). De beleidsvoorbereiding kenmerkt zich door: het verzamelen, analyseren en bediscussiëren van informatie, het bepalen van de beleidsdoelen, het selecteren van bewezen effectieve beleidsinstrumenten en het formuleren van het beleidsvoorstel. $\mathrm{Bij}$ voorkeur worden meerdere beleidssectoren betrokken bij dit proces. De huidige praktijk laat zien dat vaak alleen de beleidssector VGZ het beleidsproces trekt, al dan niet ondersteund door haar GGD.

Gemeenten kunnen, gezien de vaak beperkte gemeentelijke budgetten, streven naar het maximaliseren van gezondheidswinst. Dit betekent dat de middelen vooral worden ingezet voor uniforme doelgroepen waarvan verwacht mag worden dat ze goed bereikt kunnen worden (bijvoorbeeld via scholen), positief reageren op de aangeboden interventies en maximale gezondheidswinst opleveren. Dit zijn vaak mensen met een gemiddelde of hoge sociaal-economische status die makkelijk te motiveren zijn tot verandering, ook wel de vernieuwers of 'early adopters' genoemd (88). Uit het oogpunt van kosteneffectiviteit kan dit een plausibele overweging zijn (89). Echter, gemeenten kunnen ook streven naar het verkleinen van sociaal-economische gezondheidsverschillen (SEGV) en hun gezondheidsbeleid expliciet richten op groepen met een hoogrisico: mensen met de grootste gezondheidsachterstanden en een lage sociaal-economische status $(21,49,90)$. Dit betekent dat de middelen worden ingezet om bij moeilijk bereikbare doelgroepen gezondheidswinst te realiseren (bijvoorbeeld via wijkgericht werken). De kosteneffectiviteit van deze interventies is meestal minder gunstig (89). Vanuit welk perspectief gemeenten een bijdrage willen leveren aan het lokale gezondheidsbeleid, welke gezondheidsdoelen zij wil bereiken en welke financiële middelen zij bereid zijn te reserveren voor publieke gezondheid is een vraag die uiteindelijk in de gemeenteraad wordt beantwoord. Een GGD kan deze besluitvorming vanuit haar expertise inhoudelijk samen met gemeenten voorbereiden en gemeenten bestuurlijk en ambtelijk (on)gevraagd adviseren. Maar inhoudelijke argumenten voor een goed volkgezondheidsbeleid worden vaak overschaduwd door politieke afwegingen over inzet van financiële middelen. Het politieke besluit in de gemeenteraad beïnvloedt mede de (lokale) mogelijkheden om gezondheidsbeleid te ontwikkelen en te implementeren. In tijden van bezuinigingen wordt vooral voor de wettelijke taken met veel beleidsvrijheid, zoals gezondheidsbevordering en ouderengezondheidszorg, door de politiek kritisch gekeken naar de beschikbare financiële middelen. Het is daarna aan het college van burgemeester en wethouders (B\&W) en aan het ambtelijke apparaat om dat beleid ten uitvoer te brengen, in samenwerking met de GGD en eventueel andere externe partijen, en zo de beoogde doelen te realiseren en te evalueren (91). 


\subsection{De focus van het onderzoek}

Uit de voorgaande paragrafen blijkt dat bij complexe gezondheidsproblemen, zoals overgewicht, diverse factoren een rol spelen en inzet vanuit verschillende sectoren essentieel is. Immer naast een leefstijlbeïnvloeding zijn ook veranderingen in de sociaal-economische, culturele en fysieke omgeving noodzakelijk (10). VWS bepleit het ontwikkelen van integraal gezondheidsbeleid, maar deze staat binnen Nederlandse gemeenten nog in de kinderschoenen $(19,21,35$ ). Via de Wpg zijn gemeenten en GGD weliswaar nauw met elkaar verbonden, maar in de praktijk wordt er nog onvoldoende gebruik gemaakt van elkaars expertise bij het ontwikkelen van integraal gemeentelijk gezondheidsbeleid. Daar steeds meer wettelijke zorgtaken worden gedecentraliseerd dienen zich op lokaal niveau nieuwe kansen aan om integraal gezondheidsbeleid te ontwikkelen. Dit vraagt om meer intersectorale samenwerking; verticaal binnen het beleidsterrein VGZ en horizontaal met andere beleidsterreinen dan VGZ en in het verlengde daarvan met de GGD.

Dit proefschrift verkent de lokale ontwikkelmogelijkheden van integraal gezondheidsbeleid. Het accent van het onderzoek ligt op het bevorderen van intersectorale samenwerking binnen gemeenten in de eerste twee stappen van het beleidsproces voor het complexe gezondheidsprobleem overgewicht. Tevens is met dit onderzoek geprobeerd meer inzicht te verwerven in de ondersteuningsmogelijkheden van een GGD bij de ontwikkeling van lokaal integraal gezondheidsbeleid. De Zuid-Limburgse gemeenten hebben in 2007 het landelijke speerpunt overgewicht overgenomen als regionale beleidsprioriteit en daarbij aangegeven het accent te willen leggen op een integrale aanpak. De GGD Zuid Limburg is gevraagd haar gemeenten beleidsmatig te ondersteunen bij de uitwerking van een dergelijke integrale aanpak. Vanuit het samenwerkingsconvenant 'Gezondheidsbevordering in lokaal perspectief' (92) dat in 2005 is afgesloten tussen het Nationaal Instituut voor Gezondheidsbevordering en Ziektepreventie (NIGZ), de 19 Zuid-Limburgse gemeenten en de GGD Zuid Limburg (2005-2008) heeft de GGD in samenwerking met het NIGZ een begeleidingstraject ontwikkeld om de Zuid-Limburgse gemeenten te stimuleren intern binnen de eigen organisatie meer intersectoraal samen te werken rondom het gezondheidsprobleem overgewicht $(92,93)$. Binnen dit onderzoek is het begeleidingstraject zowel procesmatig als op effect geëvalueerd. Overgewicht is een zogenaamd 'wicked problem waar met beperkte kennis over causale relaties en een mogelijk geschikte aanpak, in samenspraak met veel actoren vanuit verschillende beleidsterreinen beslissingen genomen dienen te worden $(72,73)$. Via een lerende ontwerpstrategie wordt daarom geprobeerd het beleid voor dit gezondheidsprobleem (groten)deels gelijktijdig lokaal te ontwikkelen én uit te voeren (42). Met het uitgevoerde onderzoek, dat vanuit de Academische Werkplaats Publieke Gezondheid Limburg (94) is geïnitieerd, proberen wij antwoord te geven op de vraag of het door ons ontwikkelde lokale begeleidingstraject effect heeft gehad. Heeft het begeleidingstraject de onderlinge samenwerking tussen verschillende beleidssectoren binnen Zuid-Limburgse gemeenten, inclusief de GGD Zuid Limburg, bevorderd? En heeft het traject bijgedragen aan het ontwikkelen van lokaal integraal gezondheidsbeleid?

\section{Conceptueel model}

Om te kunnen bepalen of het uitgevoerde begeleidingstraject effect heeft gehad binnen gemeenten is gebruikt gemaakt van een conceptueel model. Voor het formuleren van gemeentelijk integraal gezondheidsbeleid is het belangrijk om continue (in)formele interactie tussen gemeentelijke actoren uit verschillende beleidsterreinen en op drie verschillende functieniveaus te stimuleren, inclusief de GGD $(20,77,78)$ (zie paragraaf 1.5). Op basis van theorieën over organisatieontwikkeling en gedragsverandering is dit conceptueel model ontwikkeld (zie figuur 1.8) en zijn determinanten geïnventariseerd per gemeentelijk functieniveau (strategisch/bestuurlijk, tactisch/management en operationeel /individueel) die duurzame samenwerking bevorderen binnen een gemeentelijke organisatie. Het model kan beschouwd worden als een ideaal-typisch model, dat wil zeggen dat onder ideale omstandigheden alle determinanten positief beïnvloed moeten worden om tot goede intersectorale samenwerking te kunnen komen.

Uit de literatuur blijkt dat er afhankelijkheidsrelaties zijn tussen de verschillende systeemniveaus. Zo blijkt dat op strategisch niveau succesvolle samenwerking tussen bestuurders sterk wordt bepaald door de politieke prioriteit van integraal gezondheidsbeleid binnen een gemeente, gemeentelijk draagvlak/leiderschap en het beschikbaar stellen van middelen (menskracht/geld). De realisatie van integraal gezondheidsbeleid vraagt om agenda-setting van een bepaald gezondheidsprobleem op bestuurlijk niveau om een thema politieke prioriteit te geven $(95,96)$ Gemeentelijk draagvlak/leiderschap wordt ervaren als deze politieke prioriteit ook zichtbaar wordt uitgedragen door de verantwoordelijke bestuurder (97-99). Wanneer bestuurlijk en in het verlengde daarvan ambtelijk draagvlak wordt ervaren kan het beleidsontwikkelingsproces daadwerkelijk starten. Succesvolle samenwerking op tactisch niveau wordt sterk bepaald door steun van het afdelingshoofd of -managers en in het verlengde daarvan steun van de portefeuillehouder. De beleidscapaciteit in de vorm van het aantal beschikbare uren voor volksgezondheid en welzijn en de cultuur van de organisatie zijn bepalend voor duurzame samenwerking 1100 101). Managers kunnen beleidsmedewerkers faciliteren of beperken in hun activiteiten op operationeel niveau en zij spelen een essentiële rol bij het steunen en uitdragen van organisatieveranderingen. Om de cultuur binnen de beleidssector te kunnen veranderen, invloed uit te oefenen op gedeelde waarden en normen onder collega's, speelt een manager een belangrijke rol. Bij managers en binnen afdelingen bestaan visies over de wijze waarop een beleidsproces dient te worden doorlopen. En in het verlengde daarvan over de manier waarop er intern en extern met andere beleidsterreinen dient te worden samengewerkt. Zo is het van belang hoe men denkt over het al dan niet inzetten van de GGD bij beleidsontwikkeling en -uitvoering van integraal 
gezondheidsbeleid en de onderlinge samenwerking tussen de GGD en de gemeente. Op operationeel niveau wordt succesvolle samenwerking sterk bepaald door kennis en houding bij individuele medewerkers ten aanzien van integraal gezondheidsbeleid. Ook van belang zijn de ervaren steun van collega's bij het ontwikkelen van integraal beleid, vaardigheden (het vertrouwen in eigen kunnen om integraal gezondheidsbeleid actief uit te dragen en verbindingen te leggen met collega's van andere beleidsterreinen) en uitkomstverwachtingen (inzicht in belemmerende en bevorderende factoren) $(100,102)$. Onderlinge samenwerking is een spel van individuen en de omgeving waarin ze functioneren op alle drie de niveaus (103), hetgeen zijn uitwerking heeft op de concrete samenwerking tussen beleidsterreinen en vervolgens op de mogelijkheden to integrale beleidsontwikkeling (zie Figuur 1.8).

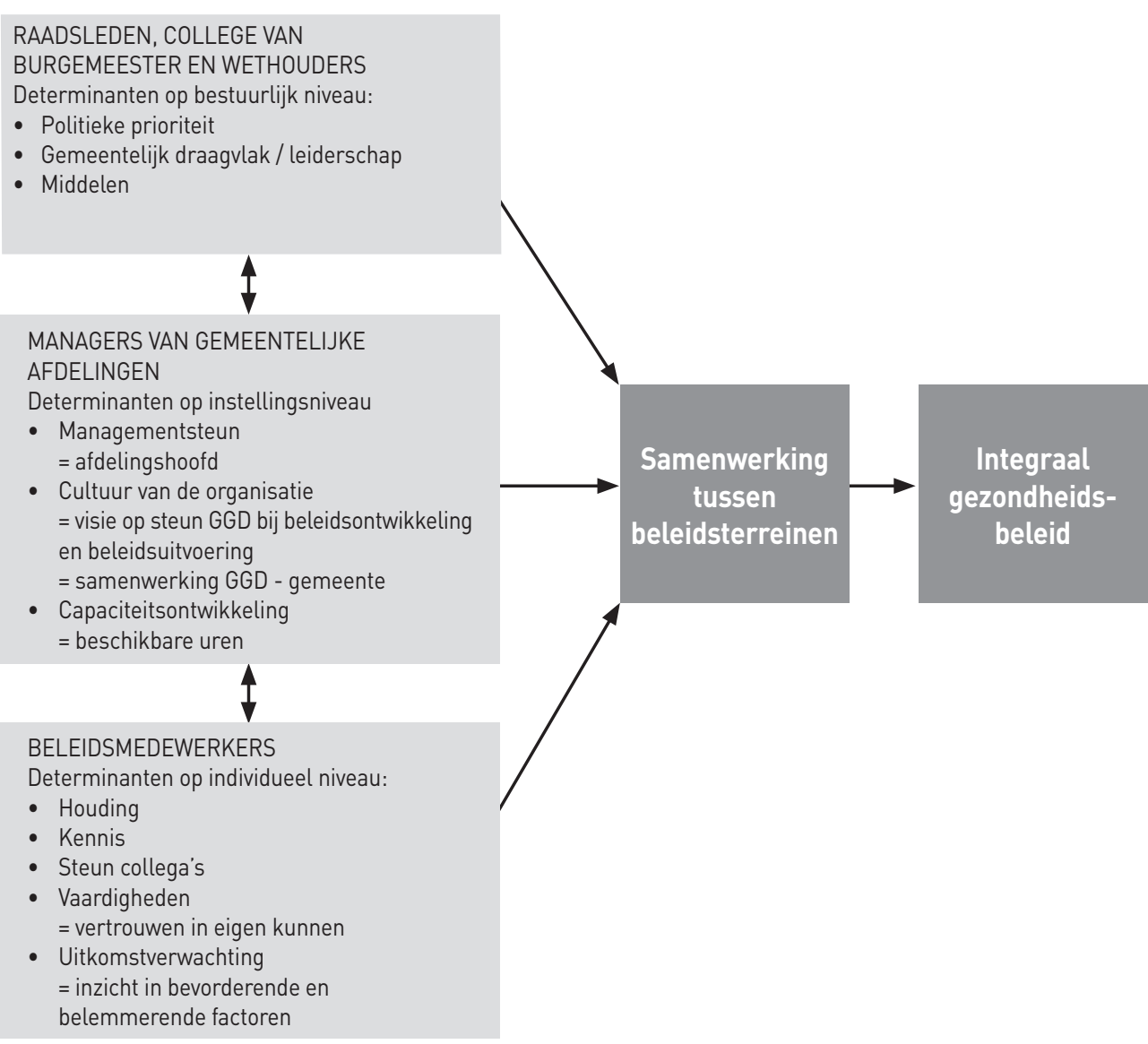

Figuur 1.8: Determinanten naar gemeentelijke actor en systeemniveau (77]
Het begeleidingstraject 'Integraal gezondheidsbeleid overgewicht' (IGBO)

De literatuur geeft aan dat - om te komen tot intersectorale samenwerking - het belangrijk is dat institutionele barrières en de verschillende werkwijzen binnen beleidssectoren worden herkend. Agenda-setting en continue interactie tussen sectoren vergroten de kansen op een gezamenlijke probleemdefiniëring en -oplossing. Dit proces vraagt om verticale en horizontale coördinatie en afstemming. Het faciliteren van dialogen tussen verschillenden beleidsterreinen is een belangrijk onderdeel van het beleidsproces (104). Belangrijke stappen in dit coördinatieproces zijn: uitnodigen (attracting), sturen (guiding) en verbinden (brokering) (105). Om barrières te overwinnen in dit samenwerkingsproces is het essentieel om ruimte te creëren om tot onderlinge afstemming te komen, de zogenaamde 'neutral white space' (105). Letterlijk en figuurlijk betekent dit ruimte creëren binnen een gemeentelijke organisatie om samenwerkingsrelaties op te bouwen en te onderhouden, om betrokkenheid te organiseren en gezondheid te verbinden met doelstellingen van verschillende actoren (28). Idealiter dienen beleidsmedewerkers van verschillende gemeentelijke beleidsterreinen onderling kennis uit te wisselen en samen beleidsplannen op te stellen. Dit vraagt om bereidheid van gemeenten om te investeren in integrale beleidsontwikkeling (in dit onderzoek beperkt tot de eerste twee stappen van het beleidsproces).

Zoals reeds in paragraaf 1.2 is aangegeven staat de ontwikkeling van integraal gezondheidsbeleid binnen Nederlandse gemeenten nog in de kinderschoenen. Veel kennis over effectieve maatregelen voor het ontwikkelen van lokaal integraal gezondheidsbeleid komt uit het buitenland en is nog onvoldoende onderzocht voor de Nederlandse situatie $(29,39,40)$. Toch hebben de GGD Zuid Limburg en het NIGZ geprobeerd op basis van beperkt beschikbare wetenschappelijke kennis en internationale ervaringen én uitgaande van de bestaande samenwerkingsrelatie tussen de GGD Zuid Limburg en haar gemeenten een begeleidingstraject te ontwikkelen en uit te voeren. Via een lerende ontwerpstrategie is geprobeerd om samen met gemeenten te zoeken naar innovatieve mogelijkheden om integraal beleid te formuleren voor het gezondheidsprobleem overgewicht. De focus van het gemeentelijke begeleidingstraject IGBO lag op het versterken van de verticale (binnen het beleidsterrein VGZ) en de horizontale samenwerking (tussen verschillende beleidsterreinen) (zie paragraaf 1.5, Figuur 1.7)

Gedurende het driejarige begeleidingstraject zijn verschillende interventies per systeemniveau in de negen begeleidingsgemeenten geïmplementeerd:

\section{- Strategisch niveau:}

Er zijn drie regionale startconferenties gehouden voor gemeentelijke bestuurders met volksgezondheid in portefeuille. Politieke prioriteit kan de interne intersectorale samenwerking binnen een gemeentelijke organisatie bevorderen $(95,96)$. Tijdens deze conferenties is he 
belang van agendasetting en pleitbezorging, gemeentelijk draagvlak en leiderschap én het genereren van middelen (geld en menskracht) voor een integrale beleidsontwikkeling en een integrale aanpak van het gezondheidsprobleem overgewicht benadrukt. Halverwege de begeleidingsperiode zijn de tussentijdse resultaten aan de bestuurders toegelicht.

\section{- Tactisch niveau:}

De gemeentelijke afdelingsmanagers zijn via hun bestuurders en beleidsmedewerkers geïnformeerd over de deelname van de eigen gemeente aan het begeleidingstraject, het belang van integraal gezondheidsbeleid en de noodzaak tot meer intersectorale samenwerking binnen de gemeentelijke organisatie. Concreet betekent dit verticale beleidsafstemming binnen de eigen afdeling en horizontale afstemming met andere afdelingen als de beleidsmedewerker dit initieerde. De afdelingsmanagers dienden akkoord te gaan met een minimale extra inzet van 2 uur per week van de beleidsmedewerker VGZ.

\section{- Operationeel niveau:}

Bij de start is er een masterclass uitgevoerd voor gemeentelijke beleidsmedewerkers VGZ en gezondheidsbevorderaars van de GGD. Tijdens deze masterclass is het gebruik van de beleidsinstrumenten determinantenbeleidsscreening (DBS), quickscan facetbeleid (QSF) en gezondheidseffectscreening (GES) geïllustreerd (106). Het zijn instrumenten die behulpzaam kunnen zijn bij de uitwerking van integraal gezondheidsbeleid. Om de GGD gezondheidsbevorderaars voor te bereiden op hun beleidsadviserende taak binnen het begeleidingstraject hebben zij nog vier extra trainingen ontvangen.

Ter bevordering van een actieve en gezamenlijke leeromgeving $(28,105)$ is per gemeente een trio gevormd bestaande uit de beleidsmedewerker VGZ, een gezondheidsbevorderaar vanuit de GGD en een medewerker van het NIGZ. Gedurende 30 maanden heeft dit trio gewerkt aan het actief stimuleren van intersectorale samenwerking binnen de gemeente. Hiertoe hebben zij allereerst een analyse gemaakt van de lokale gezondheidssituatie, he politieke en bestuurlijke krachtenveld en de lopende projecten binnen een gemeente. Vervolgens vond een intakegesprek plaats met de beleidsmedewerker volksgezondheid en portefeuillehouder volksgezondheid om aangrijpingspunten voor de aanpak van overgewicht te bespreken en om een adequat beeld te krijgen van heersende opvattingen en de macht van diverse actoren die voor het beleid van belang zijn (42). Het trio heeft gezamenlijk gewerkt aan de beleidsvoorbereiding door allereerst het (lokale) overgewicht probleem te analyseren met actuele gezondheidscijfers, beleidsdoelstellingen te formuleren, gewenste resultaten (doelen) te benoemen, een werkplan op te stellen met te ondernemen activiteiten actoren/beleidsterreinen te benoemen die betrokken dienden te worden en een tijdspad uit te werken.
Tussentijds vond er op eigen initiatief overleg plaats met relevante actoren op strategisch en tactisch niveau. Via zeven intervisiebijeenkomsten hebben de trio-leden kennis en vaardigheden met elkaar gedeeld en bediscussieerd en werd het traject inhoudelijk aangestuurd. Experts op het vlakvan integraal beleid zijn uitgenodigd voor deze bijeenkomsten en reflecteerden op de lokale plannen en activiteiten. Het was de bedoeling dat het trio een integraal beleidsplan zou ontwikkelen dat voorgelegd kon worden ter besluitvorming aan het college van B\&W en de gemeenteraad, zodat het daarna geïmplementeerd kon worden.

Zoals uit het voorgaande blijkt is - in aansluiting op de bestaande samenwerkingsrelaties tussen de GGD Zuid Limburg en haar gemeenten - het accent binnen het begeleidingstraject in eerste instantie gelegd op het ondersteunen van het operationele niveau (de beleidsmedewerker volksgezondheid) en in mindere mate op het strategische niveau (de portefeuillehouder volksgezondheid) en het tactische niveau (de afdelingsmanager volksgezondheid). De deelnemende gemeenten konden zelf aangeven op welke wijze zij intern wilden gaan werken aan het vergroten van het draagvlak voor intersectorale afstemming en samenwerking en welke innovatieve beleidsvoorstellen men wilde gaan uitwerken. Vanuit de GGD heeft een beperkte inhoudelijke sturing plaatsgevonden, het accent lag vooral op het samen zoeken naar innovatieve oplossingen en interne mogelijkheden tot samenwerking.

\section{Onderzoeksvragen en methoden}

Dit proefschrift heeft tot doel inzicht te verwerven in de gemeentelijke mogelijkheden om integraal gezondheidsbeleid te bevorderen. In dit onderzoek ligt de focus op het interne gemeentelijke beleidsproces tussen portefeuillehouders, afdelingsmanagers en beleidsmedewerkers ten behoeve van de integrale beleidsontwikkeling voor het gezondheidsprobleem overgewicht. Vormen van publiek-private samenwerking, zoals bijvoorbeeld met zorgverzekeraars, huis artsen of het bedrijfsleven welke in de praktijk vaak onderdeel kunnen zijn van het gemeentelijke integrale gezondheidsbeleid voor overgewicht, zijn niet meegenomen in dit onderzoek.

De onderzoeksvraag die binnen het beschreven onderzoek centraal staat is:

Kunnen gemeenten gestimuleerd worden tot meer intersectorale samenwerking en integrale beleidsontwikkeling voor het gezondheidsprobleem overgewicht?

Om deze onderzoeksvraag te kunnen beantwoorden zijn de volgende vier deelvragen geformuleerd:

1. Hoe kijken gemeenten aan tegen intersectorale samenwerking en integraal gezondheidsbeleid?

2. Stimuleert lokale begeleiding gemeentelijke intersectorale samenwerking? 
3. Wat is de rol van het gemeentelijke management bij het ontwikkelen van integraal gezondheidsbeleid?

4. Wat zijn de effecten van het uitgevoerde gemeentelijke begeleidingstraject voor 'Integraal gezondheidsbeleid overgewicht'?

Om de beschreven vragen te kunnen beantwoorden is het door ons ontwikkelde gemeentelijke begeleidingstraject 'Integraal gezondheidsbeleid overgewicht' (IGBO) via actiebegeleidend onderzoek (107) geëvalueerd, zowel op proces als effect. Om inzicht te krijgen in het proces dat iedere deelnemende gemeente heeft doorlopen zijn de uitgevoerde activiteiten via logboeken verslagen, intervisiebijeenkomsten en trainingen geëvalueerd. Deze manier van evalueren biedt tevens de mogelijkheid om praktijkervaringen direct bruikbaar te maken voor andere gemeenten en de voortgang van het lokale proces te stimuleren. Naar aanleiding van signalen over beperkte betrokkenheid van afdelingsmanagers VGZ bij het initiëren van intersectorale samenwerking en het formuleren van integraal gezondheidsbeleid zijn diepte-interviews met managers gehouden. Om het effect van het lokale begeleidingstraject te kunnen bepalen is voorafgaand aan de start en na afloop van het begeleidingstraject IGBO bij Limburgse gemeenten met behulp van een digitale vragenlijst onderzoek gedaan naar hun zienswijze over intersectoraal samenwerken bij het ontwikkelen van integraal gezondheidsbeleid. De gerealiseerde integrale eindproducten van het begeleidingstraject zijn conform de beleidscyclus ingedeeld en voorzien van een score, waarbij score 1 staat voor afwezigheid van beleid en score 5 voor integraal beleid dat wordt geïmplementeerd. Over de verschillende onderdelen van het onderzoek zijn aparte artikelen geschreven, per artikel wordt de methode voor dat specifieke onderdeel van het onderzoek nader beschreven.

\section{Opbouw van dit proefschrift}

Dit proefschrift bestaat uit vijf artikelen. Het eerste hoofdstuk beschrijft de definitie van integraal gezondheidsbeleid en het gebruik van deze vorm van beleidsontwikkeling in Nederland, dit in het verlengde van de gemeentelijke taakstelling op het vlak van integraal gezondheidsbeleid. Intersectorale samenwerking wordt gezien als een voorwaardenscheppend proces om te komen tot formulering van integraal beleid. Binnen dit onderzoek ligt het accent op gemeentelijke intersectorale samenwerking

Het belang van lokaal integraal gezondheidsbeleid wordt landelijk steeds vaker benadrukt en gemeenten worden gestimuleerd om integraal gezondheidsbeleid te ontwikkelen. In hoofdstuk 2 wordt aangegeven hoe gemeenten zelf aankijken tegen integraal gezondheidsbeleid en de eigen mogelijkheden om intersectoraal samen te werken. Portefeuillehouders, afdelingshoofden/managers en beleidsmedewerkers zijn via een digitale vragenlijst hierover bevraagd (voormeting). Hoofdstuk 3 beschrijft een begeleidingstraject dat de GGD Zuid Limburg en het NIGZ in negen
Zuid-Limburgse gemeenten hebben uitgevoerd om gemeenten te helpen bij het ontwikkelen van integraal gezondheidsbeleid ten aanzien van het gezondheidsprobleem overgewicht. Via actiebegeleidend onderzoek is het begeleidingstraject gedurende drie jaar procesmatig geëvalueerd. In hoofdstuk $\mathbf{4}$ wordt de rol van de gemeentelijke manager nader bekeken. Uit de resultaten van de voormeting blijkt dat het tactische niveau niet of nauwelijks betrokken is bij intersectorale samenwerking. Via diepte-interviews bij 13 gemeentelijke managers VGZ is daarom de rol van afdelingsmanagers VGZ binnen het gemeentelijke beleidsproces geëxploreerd. In hoofdstuk 5 worden de effecten van beleidsondersteuning op de ontwikkeling van gemeentelijke intersectorale samenwerking en integraal beleid beschreven. De resultaten van de voormeting zijn hiervoor vergeleken met die van de nameting. In hoofdstuk $\mathbf{6}$ worden alle resultaten van de door ons uitgevoerde onderzoeken met elkaar verbonden. De resultaten van de voor- en nameting, de bevindingen uit de procesevaluatie van het begeleidingstraject en de diepte interviews met de gemeentelijke afdelingsmanagers VGZ. Hoofdstuk $\mathbf{7}$ tenslotte omvat een reflectie op de beschreven onderzoeksresultaten, aanbevelingen voor de praktijk en een discussie over de vraag of integraal gezondheidsbeleid voor gemeenten een realistische uitdaging is of meer neigt naar utopie. 


\subsection{Literatuur}

1. WHO. Constitution of the World Health Organization. 2006; www.who.int/governance/eb/ who_constitution_en.pdf].

2. Mackenbach JP. De ontwikkeling van de academische public health in Nederland: twee eeuwen geschiedenis, nog altijd springlevend. Tijdschrift voor Gezondheidswetenschappen 2009;87(5):216-32.

3. Wet Publieke Gezondheid, wet van 9 oktober 2008, houdende bepalingen over de zorg voor de publieke gezondheid. [Law on Public Health], (2008).

4. Ministerie. Gezondheid dichtbij. Landelijke nota gezondheidsbeleid. Den Haag: Ministerie VWS; 2011

5. Huber M, Knottnerus JA, Green L, al e. How should we define health? BMJ 2011;343 (d4163).

6. Rijkschroeff-van der Meer ACJ. Welvaartsziekten: andere ziekten, andere aanpak. Achtergrondstudie uitgebracht door de RVZ bij het advies Preventie van welvaartsziekten. Den Haag: RVZ 2011.

7. Lalonde M. A new perspective on the health of Canadians: a working document. In: Welfare MonHa, editor. Ottawa 1974

8. WHO. Ottawa charter for health promotion. Health Promotion International1986; 1:iii-v.

9. WHO. Adelaide Recommendations. Second International Conference on Health Promotion; 5-9 April 1988; Adelaide1988.

10. Dahlgren G, Whitehead M. Policies and strategies to promote social equity in health Stockholm: Institute for futures studies 1991.

11. Gezondheidsraad. Overgewicht en obesitas. Den Haag: Gezondheidsraad 2003.

12. Nijboer C, Alting D. Gezondheidswinst door gemeentelijk facetbeleid, voorbeelden die een gezond leven bevorderen, vooral bij sociaal economisch zwakkere groepen. Woerden: NIGZ 2003.

13. Bekker M, Wallenburg I, Helderman JK. Verschuivende verhoudingen: de marges van overheidsbeleid bij overgewicht. In: Dagevos H, Munnichs G, editors. De obesogene samenleving Maatschappelijke perspectieven op overgewicht. Amsterdam: Amsterdam University Press; 2007.

14. Aarts M-J, Jeurissen MPJ, van Oers H, Schuit AJ, van de Goor IAM. Multi-sector policy action to create activity-friendly environments for children: a multiple-case study. Health Policy 2011;101:11-9.

15. Klein $\mathrm{H}$, Rorink F, editors. Verandermanagement: een plan van aanpak voor integrale organisatieverandering en innovatie. Amsterdam: Pearson Education Uitgeverij; 2005.
16. WHO Health Equity in All Urban Policies. A report on the expert consultation on Intersectoral Action (ISA) in the prevention of Noncommunicable conditions. Kobe, Japan: World Health Organization 2009 22-24 june.

17. Goumans M. Innovations in a Fuzzy Domain: Healthy Cities and (health) Policy Development in the Netherlands and the United Kingdom. Maastricht University Maastricht; 1998

18. Kickbusch I, McCann W, Sherbon T. Adelaide revisited: from healthy public policy to Health in All Policies. Health Promotion International 2008;23(1):Editorial 1-4.

19. Kickbusch I. Policy Innovation for Health. New York: Springer Science + Business Media; 2009

20. St-Pierre L. Governance tools and framework for Health in All Policies. Québec: National Collaborating centre for Healthy Public Policy. European Observatory on Health Systems and Policies.2010.

21. van der Lucht F, Polder J. Van gezond naar beter. Kernrapport Volksgezondheid Toekomst Verkenning 2010 [Dutch Public Health Status and Forecasts Report 2010]. Bilthoven Rijksinstituut voor Volksgezondheid en Milieu 2010.

22. Storm I, Zoest F, Broeder L. Integraal gezondheidsbeleid: theorie en toepassing. Bilthoven RIVM 2007.

23. White paper Together for Health: A strategic approach for the EU 2008-2013, (2007).

24. Ministerie van Volksgezondheid Welzijn en Sport. Reactie minister op advies RVZ 2000. Den Haag 2001.

25. Ministerie van Volksgezondheid Welzijn en Sport. Gezond zijn, gezond blijven. Een visie op gezondheid en preventie. [Being healthy, staying healthy. National policy vision on health and prevention.]. Den Haag: Ministerie VWS; 2007.

26. Ministerie van Volksgezondheid Welzijn en Sport. Kaderbrief 2007-2010 visie op gezondheid en preventie. Den Haag 2007

27. de Hollander AEM, Hoeymans N, Melse JM, van Oers JAM, Polder JJ. Zorg voor gezondheid - Volksgezondheid Toekomst Verkenning 2006. Bilthoven: RIVM; 2006.

28. RVZ. Publieke gezondheid. Advies uitgebracht door de RVZ aan de minister van VWS. Den Haag 2006.

29. RVZ. Buiten de gebaande paden. Inspirerende voorbeelden van intersectoraal gezondheids beleid. Zoetermeer 2009.

30. Inspectie voor de Gezondheidszorg. Concept resultaten thematisch toezicht integraal beleid. [Concept results thematic inspection on integrated policy.]. 2008.

31. van Herten L, van Reeuwijk J, Pernis M, Koornstra A. Hoe zet je facetbeleid rond gezondheid op? De beterende hand / instrumenten voor de openbare gezondheidszorg. G2004;1:26-7.

32. Aarts M-J. Children, physical activity and the environment: opportunities for multi-sector policy. Tilburg: Tilburg University 2011 
33. Storm I, Verweij A, Van der Lucht F. Integraal gezondheidsbeleid op lokaal niveau. Wat weten we en hoe nu verder? [Local integrated health policy. What do we know and how to proceed?]. Bilthoven: RIVM briefrapport 2701610042011.

34. Storm I, van Bakel A. Intersectorale samenwerking. Bilthoven: RIVM; 2011 [updated 28 juli 2011]

35. Maas J, Storm I. Integraal gezondheidsbeleid op nationaal niveau. Wat kunnen we leren van de ervaringen uit andere landen? Bilthoven: RIVM briefrapport 2701610052011.

36. Harting J, Paauwe L, Stronks K. Theoretische perspectieven op intersectorale samenwerking en integraal beleid. Een thematische review.: AMC Sociale Geneeskunde september 2011.

37. Schuit J, Storm I. Successen en valkuilen van integraal gezondheidsbeleid. Tijdschrift voor gezondheidswetenschappen 2007;85(8):415-6.

38. Smith KE, Bambra C, al e. "Partners in health? A systematic review of the impact of organizational partnerships on public health outcomes in England between 1997 and 2008. Journal of Public Health (Oxford) 2009;31(2):210-21.

39. Savelkoul M, Schuit AJ, Storm I. Terugdringen van gezondheidsachterstanden door gemeentelijk beleid. Een literatuurverkenning naar effectiviteit van fysieke en sociale omgevingsmaatregelen. Bilthoven: RIVM 2010 Contract No.: 270161003/2010.

40. RVZ, Onderwijsraad, Rob. Buiten de gebaande paden. Advies over intersectoraal gezondheidsbeleid, advies uitgebracht door de Raad voor de Volksgezondheid en Zorg, de Onderwijsraad en de Raad voor het openbaar bestuur. Zoetermeer 2009.

41. Teisman GR. De reconstructie van complexe besluitvorming: over fasen stromen en ronden In: van Heffen O, van Twist MJW, editors. Beleid en wetenschap Hedendaagse bestuurskundige beschouwingen. Alphen aan de Rijn, 1993. p. 18-32.

42. van Heffen 0, Kerkhoff AHM. Beleidsvoering in de algemene gezondheidszorg. Assen: Van Gorcum; 1997.

43. Hoogerwerf A. Beleid, processen en effecten. In: Hoogerwerf A, Herweijer M, editors. Overheidsbeleid Een inleiding in de beleidswetenschap. Alphen aan de Rijn: Samson; 1998. p. 17-36.

44. Kingdon JW, editor. Agendas, Alternatives and Public Policies: Little Brown; 1984

45. Kingdon JW. Agendas, alternatives and public policies. New York: Addison-Wesley Educational Publishers Inc.; 2003

46. Hoeijmakers M. Local health policy development processes. Health promotion and network perspectives on local health policy-making in the Netherlands. Maastricht: University Maastricht; 2005.

47. Wet Collectieve Preventie en Volksgezondheid, (1989).

48. Wet Collectieve Preventie Volksgezondheid, (2003).
49. Lamberts PHG, Steenbakkers M, Thijssen NHB, Bacus-Mujakovic S, de Vreede JJM, Hajema KJ, et al. Een gezonde kijk op Zuid-Limburg. Regionale Volksgezondheid Toekomst Verkenning 2010. Geleen: GGD Zuid Limburg 2010.

50. CGL. Handreiking Gezonde Gemeente. Bilthoven: RIVM; 2010

51. Inspectie voor de Gezondheidszorg. Staat van de gezondheidszorg 2005, deelrapport. De gemeenten zijn veel meer betrokken bij de openbare gezondheidszorg, ze moeten nu meer zelf uitvoeren. Resultaten van het toezicht op de gemeentelijke betrokkenheid 2004. Den Haag: IGZ 2005.

52. Kooiker S, Velden van der K. Een nuchtere kijk op gezond gedrag. Vier thema's voor gezondheidsbevordering. Den Haag: Sociaal en Cultureel planbureau 2007.

53. Inspectie voor de Gezondheidszorg. Zichtbare zorg openbare gezondheidszorg, verantwoording gemeentelijk gezondheidsbeleid. Visiedocument. 2009

54. Inspectie, Gezondheidszorg livd. Staat van de gezondheidszorg 2010. Meer effect mogelijk van publieke gezondheidszorg. (Health status 2010. More effect possible in public health.]. Utrecht: Ministerie VWS; 2010

55. Walg C. Inventarisatie gemeentelijke nota's Lokaal Gezondheidsbeleid. Utrecht: GGD Nederland 2010

56. Bressers J, de Jong P, Klok PJ, Korsten A. De gereedschapskist van de overheid: een inventarisatie. Assen: Van Gorcum; 1993.

57. den Hollander J. Krachtenveldanalyse als instrument. Amsterdam: Van de Bunt, adviseurs voor organisatie en beleid 2008

58. van Bon-Martens M. The art of Regional Public Health Reporting. Strengthening the knowledge base for local public health policy. Tilburg: Universiteit van Tilburg; 2011

59. De Goede J. Knowledge in process. Tilburg: Tilburg University; 2011.

60. Wetwijziging Wet Publieke Gezondheid 2e tranche, (2011).

61. RVZ. Preventie van welvaartsziekten, effectief en efficiënt georganiseerd. Den Haag: Raad voor de Volksgezondheid en Zorg 2011.

62. Walg CB. Relatie tussen de Wcpv en de Wmo. Kansen voor de openbare gezondheidszorg Deventer: GGD Gelre-IJssel 2006

63. Wet Maatschappelijke Ondersteuning, (2007).

64. Mosis G, Colkesen EB, Ferket BS, Mathijssen JJ, Peters RJG, Kraaijenhagen RA, et al. A holistic approach for prevention and early diagnostics: personal health management with web-based personal records. In: Kuhn KA, Warren JR, Leong T-Y, editors. Proceedings of the 12th World Congres on Health (Medical) Informatics; building sustainable health systems. Amsterdam: IOS Press; 2007. p. 1744-47.

65. NIPED. Prevent model: geïntegreerd gezondheidsmanagement. In: NIPED, editor Amsterdam: www.prevent.congres.nl; 2010. 
66. Ministerie van Volksgezondheid Welzijn en Sport. Derde voortgangsrapportage Wmo. Den Haag 2008.

67. de Klerk M, Gilsing R, Timmermans J. Op weg met de Wmo. Evaluatie van de Wet maatschappelijke ondersteuning 2007-2009. Den Haag: Sociaal en Cultureel Planbureau 2010.

68. RVZ. Van zz naar gg. Acht debatten, een sprekend verhaal. Den Haag RVZ2010.

69. Baecke JAH, Derickx CL. Toekomstvisie op publieke gezondheid. Maatschappelijke vraagstukken centraal - verbinden verschillende beleidsdomeinen. Den Haag: VNG 2009.

70. Gilsing R. De beleidstheorie van decentralisatie en het belang van democratische zelfsturing. In: Keuzenkamp S, editor. Decentralisatie en de bestuurskracht van de gemeente. Utrecht: SCP; 2009.

71. Utrecht, Gezond. Aanpak 'Gezonde Wijk Overvecht' succesvol. Trendbreuk: 4\% minder zorgkosten. 9 juni 2011.

72. Rittel HJW, Webber MM. Dilemmas in a general theory of planning. Policy Sciences 1973(4):155-69.

73. van Bueren EM, Klijn EH, Koppenjan JFM. Dealing with Wicked Problems in Networks: Analyzing an Environmental Debate from a network Perspective. Journal of Public Administration Research and Theory 2003;13(2):193-212.

74. Steenbakkers M, Jansen M, Hesdahl B, ten Dam J, Maarse H. Gemeentelijke intersectorale samenwerking stimuleren: Lokale begeleiding bij het ontwikkelen van integraal gezondheidsbeleid. [Stimulating municipal government inter-sectoral collaboration: local support for the development of integrated health policy]. Tijdschrift voor gezond-heidswetenschappen 2011;89(5):266-73.

75. Jackson SF, Perkins F, Khandor E, Cordwell L, Hamann S, Buasai S. Integrated health promotion strategies: a contribution to tackling current and future health challenges. Health Promotion International 2007;21(S1):75-83.

76. Pagliccia N, Spiegel J, Alegret M, Bonet M, Martinez B, Yassi A. Network analysis as a tool to assess the intersectoral management of health determinants at the local level: A report from an exploratory study of two Cuban municipalities. Social Science \& Medicine 2010;71:394-9.

77. Jansen M. Mind the gap: collaboration between practice, policy and research in local public health. Maastricht: University Maastricht; 2007.

78. de Leeuw E, McNess A, Stagnitti K, Crisp B. It's research, Jim, but not as we know it.. Acting at the Nexus. Integration of Research, Policy and Practice. Geelong: Deakin University 2007
79. Steenbakkers M, Jansen M, Maarse H, De Vries N. Sturing op integraal gezondheidsbeleid: de rol van het gemeentelijke management. [The role of municipal departmental managers in achieving integrated health policy]. Tijdschrift voor gezondheidswetenschappen 2012;90(2):89-96.

80. de Bruijn H. Framing, over de macht van taal in de politiek: Atlas; 2011.

81. Wikipedia. Framing (social sciences). 2012 [updated maart 2012]; http://en.wikipedia.org/ wiki/Framing_(socialsciences)].

82. Maarse JAM. Sturing op gezondheidsdoeleinden en gezondheidswinst op macroniveau Achtergrondstudie bij RVZ-rapport: Sturen op gezondheid. [Directing on health targets and health improvement on macro level. A background study by RVZ. Control on health.]. In: RVZ, editor. 2011.

83. Hunter DJ. Zorg voor gezondheid vergt meer dan gezondheidszorg: de noodzaak van een nieuw paradigma [Care for health is more than health care: the need for a new paradigm] G-lezing; 14 november; Utrecht 2007.

84. Steenbakkers $\mathrm{M}$, Jansen M, Maarse H, De Vries N. Lokaal integraal gezondheidsbeleid: effecten van beleidsondersteuning op de ontwikkeling van gemeentelijke intersectorale samenwerking en integraal beleid. [Integrated local health policy: effects of local support on the development of municipal inter-sectoral collaboration and integrated health policy] Tijdschrift voor gezondheidswetenschappen 2012;90(3):184-92.

85. Meijer AWM, Ouwelant van den W. De GGD nader beschouwd. Utrecht: Landelijke vereniging voor GGD-en en Universiteit Maastricht. 1998.

86. Projectgroep Fusie. Openbare Gezondheidszorg. Begripsbepaling en uitdagingen voor de regio Zuid-Limburg. Fusiebeslisdocument deel 1: GGD Zuid Limburg 2005.

87. Projectgroep Fusie. Missie, visie en strategische doelen voor de regio Zuid-Limburg. Fusiebeslisdocument deel 2: GGD Zuid Limburg 2005.

88. Rogers EM. Diffusion of innovations. New York: Free press; 2003

89. Ronckers S. Economic evaluation of preventive programs for cardiovasculair diseases. Maastricht: University Maastricht; 2007.

90. Stronks K, Hulshof J. De kloof verkleinen. Theorie en praktijk van de strijd tegen sociaaleconomische gezondheidsverschillen. Assen: Koninklijke van Gorcum; 2001.

91. Derksen W, Schaap L. Lokaal bestuur [Local government]. 5e druk ed: Elsevier; 2007.

92. Nationaal Instituut voor Gezondheidsbevordering en Ziektepreventie. Gezondheidsbevordering in lokaal perspectief. Vaals: Zuid Limburgse gemeenten, GGD Zuid Limburg, NIGZ 2005.

93. Steenbakkers M, Jansen M, de Vries NK. Lokaal integraal gezondheidsbeleid versterken welke ontwikkelingsmogelijkheden zien gemeenten eigenlijk? Tijdschrift voor gezondheidswetenschappen / NCVGZ 2009;87(3):42. 
94. GGD Zuid Limburg, Universiteit Maastricht. Academische Werkplaats Publieke Gezondheid Limburg (AW). Maastricht 2006.

95. Stone DA, Stone DA. Policy paradox: the art of political decision making. New York: Norton \& Company; 2002.

96. Walt G. Health policy. An introduction to process and power. London: Zed books; 2004.

97. Foryth DR. Leadership. Group Dynamics. 3ed ed. Belmont: Wadsworth Publishing Company; 1999.

98. Wilson JL. Leadership development: working together to enchance collaboration. J Public Health Manag Pract 2002;8(1):21-6.

99. de Jong J, den Hartog D. Leadership as a determinant of innovative behavior. A conceptual framework. Zoetermeer Scales 2003.

100. Steckler A, Goodman RM, Kegler MC. Mobilizing organizations for health enchancement. In: Glanz K, Rimer BK, Lewis FM, editors. Health behavior and health education Theory, research and practice. 3 ed ed. San Francisco: Jossey-Bass; 2002. p. 335-60.

101. Cummings TG, Worley CG. Organization development and change. Australia 2001.

102. Fraser SW, Greenhalgh T. "Coping with complexity: educating for capability. British Medical Journal 2001;323(7316):799-803.

103. Bartholomew LK, Parcel GS, Kok G, Gottlieb NH. Planning health promotion programs, an intervention mapping approach. 2nd ed. San Francisco Jossey-Bass; 2006.

104. Fafard P. Evidence and Healthy Public Policy: Insights from Health and Political Sciences. Ottawa: National Collaborating Centre for Healthy Public Policy May 2008.

105. Warner M, Gould N. Integrating health in all policies at the local level: using network governance to create 'Virtual Reorganization by Design'. In: Kickbusch I, editor. Policy Innovation for Health. New York: Springer; 2009. p. 125-63.

106. NIGZ, Limburg GZ, gemeenten Z-L. Masterclass Integraal Gezondheidsbeleid [Masterclass on integrated health policy]. Geleen: GGD Zuid Limburg 2006.

107. Wagemakers A. Community health promotion. Facilitating and evaluating coordinated action to create supportive social environments. Wageningen: Wageningen University; 2010. 


\section{Hoofdstuk2}

Lokaal integraal gezondheidsbeleid: intersectorale samenwerking vanuit het perspectief van gemeenten

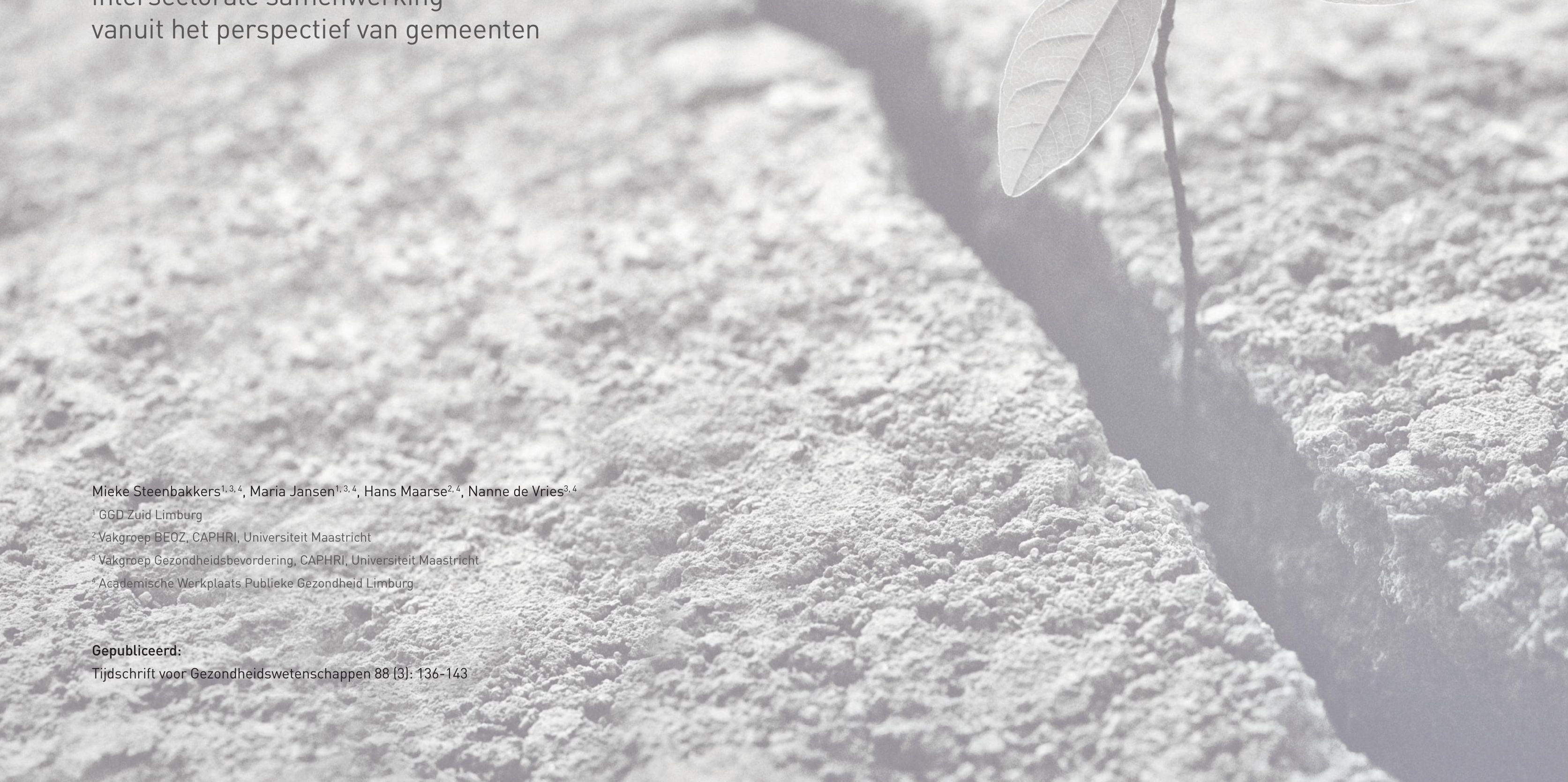




\section{Samenvatting}

Gemeenten worden gestimuleerd om integraal gezondheidsbeleid te ontwikkelen. Ondanks het feit dat gemeenten beschikken over beleidsinstrumenten die ingezet kunnen worden bij het structureel vormgeven van integraal gezondheidsbeleid staat dit integrale beleid nog in de kinderschoenen. Daarom rijst de vraag welke mogelijkheden de gemeenten zien om intersectoraal samen te werken bij het ontwikkelen van integraal gezondheidsbeleid. Portefeuillehouders, afdelingshoofden en beleidsmedewerkers zijn via een digitale vragenlijst hierover bevraagd.

De resultaten van dit onderzoek laten een consistent beeld zien. Gemeenten die gaan deelnemen aan het begeleidingstraject zien zelf meer mogelijkheden om intersectoraal samen te werken aan integraal gezondheidsbeleid dan gemeenten die niet begeleid willen worden. Binnen de gemeentelijke organisatie zijn de afdelingshoofden het minst positief over integraal gezondheidsbeleid. Vaak ontbreekt op dit tactische niveau de samenwerking met andere beleidsterreinen en is er minder draagvlak voor integraal beleid binnen het eigen beleidsterrein. Vooral op het niveau van de portefeuillehouder en beleidsmedewerker worden verbindingen gelegd met andere beleidsterreinen. De casus overgewicht maakt duidelijk dat de verschillende gemeentelijke beleidsterreinen niet bewust en vanuit parallelle belangen intersectoraal samenwerken.

Geconcludeerd wordt dat over de invloed van afdelingshoofden op de onderlinge samenwerking veel onduidelijkheid bestaat en dat intersectorale samenwerking rondom het gezondheidsprobleem overgewicht beperkt ontwikkeld is binnen gemeenten.

\subsection{Inleiding}

Vanuit het ministerie van VWS wordt steeds nadrukkelijker het belang aangegeven van integraal gezondheidsbeleid (IGB) en worden gemeenten gestimuleerd om lokaal integraal gezondheidsbeleid te ontwikkelen (1-7). Men spreekt van integraal gezondheidsbeleid, wanneer sectoren binnen en buiten het volksgezondheidsdomein samenwerken om gezondheidsschade te voorkómen en/of gezondheid te bevorderen (8-10). Om integraal beleid te kunnen ontwikkelen is intersectorale samenwerking een voorwaarde.

De ontwikkeling van integraal gezondheidsbeleid staat nog in de kinderschoenen. Het is een complex proces waarin verschillende beleidsterreinen gezamenlijk werken aan een gezondheidsprobleem en waarvoor wettelijke maar ook niet-wettelijke beleidsinstrumenten kunnen worden ingezet. Zo biedt de Wet collectieve preventie volksgezondheid (5), sinds 1 december 2008 de Wet publieke gezondheid (Wpg) (6), via de lokale nota volksgezondheid de gemeenten de mogelijkheid tot het voeren van integraal gezondheidsbeleid. Vanaf 1 januari 2007 geeft de Wet maatschappelijke ondersteuning (Wmo) gemeenten eveneens mogelijkheden tot het bevorderen van welzijn, sociale samenhang in beleidssectoren zoals wonen, ruimtelijke ordening, integratiebeleid, veiligheid en economie (11). De Wmo is een brede wet met veel mogelijkheden tot intersectorale samenwerking, maar de lokale concretisering verloopt nog moeizaam (12). Ook wat betreft de Wcpv/Wpg blijkt dat gemeenten nog onvoldoende in staat zijn om integraal beleid te voeren. Gemeenten ervaren vooral gebrek aan geld, ambtelijke capaciteit, directe bevoegdheden en politieke urgentie om gezondheidsbeleid vorm te geven en uit te voeren $(13,14)$. Naast wettelijke instrumenten om IGB te stimuleren, kan gedacht worden aan bijvoorbeeld pleitbezorging en media-aandacht waarmee publieke en politieke druk kan worden uitgeoefend. Bij de totstandkoming van de tweede lokale nota gezondheidsbeleid (2007-2011) is de indruk ontstaan dat er in de gemeenteraad frequenter vragen worden gesteld over het lokale gezondheidsbeleid, maar het komt nog steeds nauwelijks op de politieke agenda van andere beleidsterreinen (15). Ook worden bestuurlijke besluiten niet systematisch getoetst op gevolgen voor de volksgezondheid en vragen gemeenten zelden advies aan de GGD, terwijl dit stimulerend kan werken op de ontwikkeling van integraal gezondheidsbeleid $(16,17)$.

De vraag rijst: welke mogelijkheden zien gemeenten zelf om intersectoraal samen te werken om integraal gezondheidsbeleid te ontwikkelen? In de regio Zuid Limburg hebben gemeenten via hun regionale prioriteitennota aangegeven het belangrijk te vinden dat het gezondheidsprobleem overgewicht integraal wordt aangepakt $(18,19)$. Vanuit het samenwerkingsconvenant "Gezondheidsbevordering in lokaal perspectief" tussen het NIGZ, gemeenten en GGD (2005$2008)$ is een begeleidingstraject IGB ontwikkeld voor de regio Zuid-Limburg $(20,21)$. Met onder- 
zoek dat vanuit de Academische Werkplaats Publieke Gezondheid Limburg (22) is geïnitieerd, wordt geprobeerd antwoord te krijgen op de vraag of dit begeleidingstraject bijdraagt aan meer integraal gezondheidsbeleid voor het gezondheidsprobleem overgewicht.

Voorafgaand aan de start van het begeleidingstraject is bij Limburgse gemeenten onderzoek gedaan naar hun zienswijze over intersectoraal samenwerken bij het ontwikkelen van integraal gezondheidsbeleid. Hierbij is nagegaan of er verschillen bestaan tussen gemeenten die al dan niet gaan deelnemen aan het begeleidingstraject IGB, verschillen tussen het beleidterrein Volksgezondheid en Welzijn (VGZ) en andere beleidsterreinen en verschillen tussen de gemeentelijke actoren op strategisch (portefeuillehouder), tactisch (afdelingshoofd) en operationeel (beleidsmedewerker) niveau. Vergelijkbaar onderzoek is nog niet eerder in Nederland uitgevoerd. Dit artikel presenteert de verschillende uitgangsposities voor integraal gezondheidsbeleid in algemene zin en specifiek voor het gezondheidsprobleem overgewicht. Deze bevindingen zijn belangrijk om in vervolgonderzoek de meerwaarde van het begeleidingstraject te kunnen bepalen.

\subsection{Methode van onderzoek}

\section{Onderzoekspopulatie/steekproe}

De provincie Limburg telt 39 gemeenten waarvan er 32 hebben deelgenomen aan het onderzoek. Negen gemeenten nemen deel aan het begeleidingstraject IGB (conform convenant allen uit Zuid-Limburg) en 23 gemeenten niet (13 uit Noord- en Midden Limburg en 10 uit ZuidLimburg). De inwonersaantallen zijn als volgt verdeeld onder de 9 deelnemende gemeenten: 3 meer dan 90.000, 1 tussen 20.000 en 40.000, 4 tussen 10.000 en 20.000, 1 minder dan 10.000 inwoners.

Voorafgaand aan het begeleidingstraject is een vragenlijst ontwikkeld die digitaal is afgenomen bij 51 portefeuillehouders, 54 afdelingshoofden en 121 beleidsmedewerkers, verspreid over zes verschillende gemeentelijke beleidsterreinen waarvan verondersteld wordt dat deze relevant zijn bij het vormgeven van integraal gezondheidsbeleid $(23,24)$.

Werving van deelnemers vond plaats door beleidsmedewerkers VGZ de namen en mailadressen te laten aanleveren van portefeuillehouders, afdelingshoofden en beleidsmedewerkers. Indien de beleidsmedewerker geen mailadressen wilde doorgeven van collega's, kon het onderzoek binnen die gemeente niet worden uitgevoerd. Bij 7 van de 39 Limburgse gemeenten was dit het geval. Gezien de hoge response heeft er geen aanvullende schriftelijke werving plaatsgevonden.

\section{Conceptueel model}

De vragenlijst is gebaseerd op literatuur over samenwerking tussen niches (25-27) en is op beperkte schaal gepretest bij 3 beleidsmedewerkers (28). Verschillende beleidsterreinen binnen een gemeentelijke organisatie zijn te vergelijken met niches, oftewel op zichzelf staande eenheden waar een 'interface' tussen de actoren ontbreekt en waar sprake is van 'verkokering'. Om intersectorale samenwerking tot stand te brengen dienen actoren op strategisch, tactisch en operationeel niveau zowel functioneel (horizontaal) als hiërarchisch (verticaal) met elkaar in overleg te treden (27). Vertaald naar een gemeentelijke organisatie betekent dit dat portefeuillehouders (strategisch niveau), afdelingshoofden (tactisch niveau) en beleidsmedewerkers (operationeel niveau) met elkaar dienen samen te werken, zowel binnen een beleidsterrein (verticale samenwerking) als per niveau tussen verschillende gemeentelijke beleidsterreinen, inclusief de GGD als zijnde verlengd lokaal bestuur (horizontale samenwerking) (zie Figuur 1). Per niveau zijn verschillende samenwerkingsdeterminanten onderzocht (26) (zie Figuur 2). De determinanten zijn direct bevraagd met als antwoordcategorie ja/nee of indirect via stellingen met de antwoordcategorie eens/oneens. Tenzij expliciet anders is aangegeven zijn de determinanten bevraagd bij alle respondenten ongeacht hun functionaliteit.
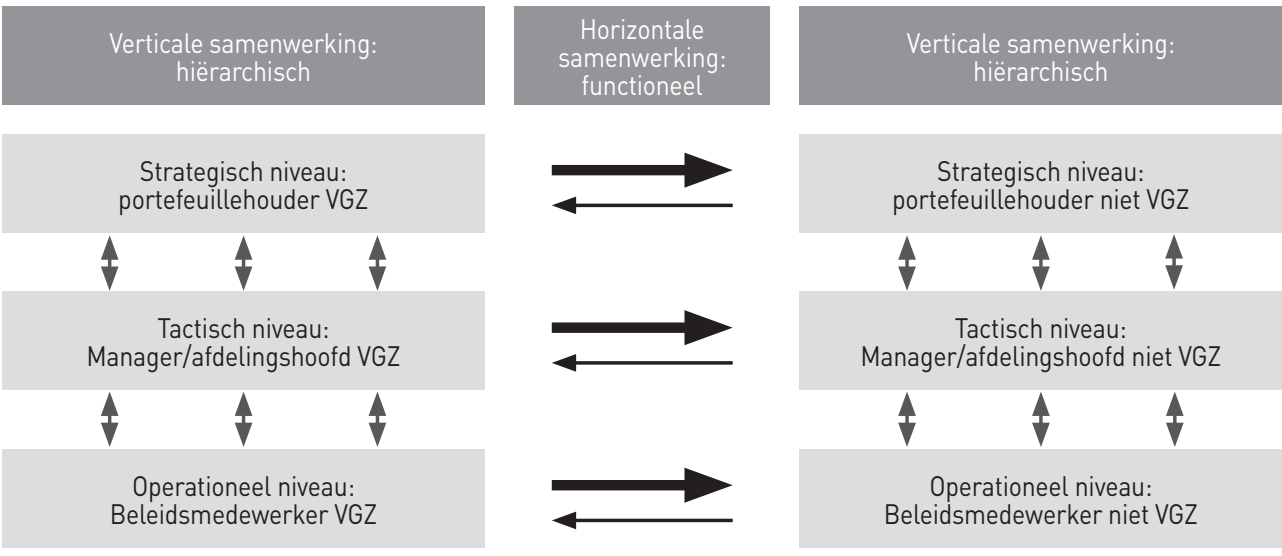

Figuur 1: Gemeentelijke intersectorale verticale en horizontale samenwerking (77)

Via 11 stellingen zijn 3 samenwerkingsdeterminanten op strategisch niveau bevraagd, namelijk de politieke prioriteit van IGB binnen een gemeente, gemeentelijk draagvlak/leiderschap en het beschikbaar stellen van middelen (menskracht/geld). Draagvlak wordt ervaren als dit ook zichtbaar wordt uitgedragen door de verantwoordelijke functionarissen (29-31). Het beschikbaar stellen van middelen wordt gezien als een indirecte uiting van draagvlak. Op tactisch niveau spelen 3 determinanten een rol, namelijk steun van portefeuillehouder en afdelingshoofd (2 stellingen), het aantal beschikbare uren voor volksgezondheid en welzijn en de cultuur van 


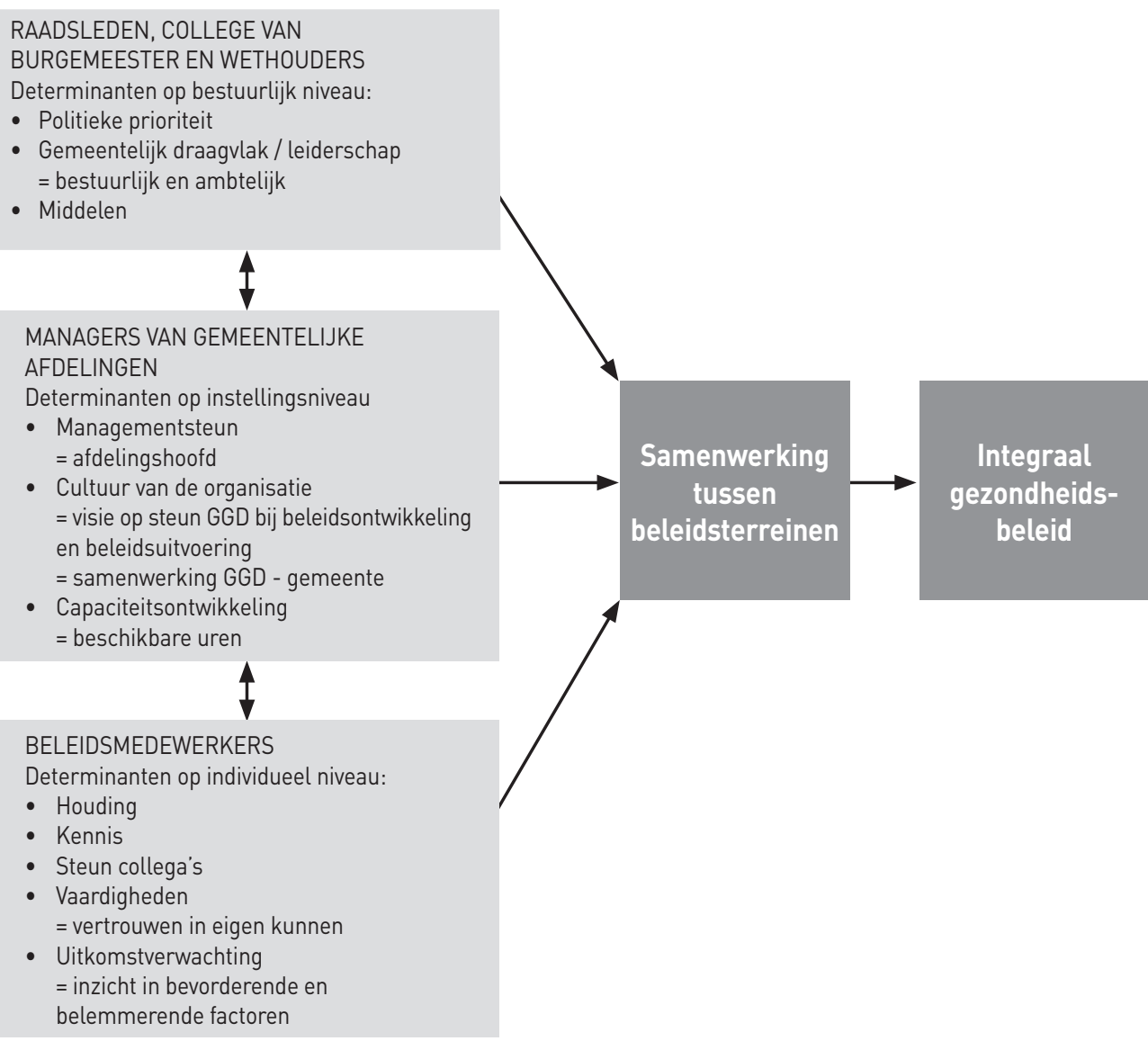

Figuur 2: Samenwerkingsdeterminanten gemeten bij gemeentelijke actoren (portefeuillehouders, afdelingshoofden en beleidsmedewerkers) op drie systeemniveaus (26)

de organisatie (7 stellingen). Qua cultuur is de visie van respondenten bevraagd ten aanzien van het inzetten van de GGD bij beleidsontwikkeling en -uitvoering van IGB en de onderlinge samenwerking tussen de GGD en de gemeente. Op operationeel niveau zijn via 10 stellingen 5 determinanten bevraagd, namelijk kennis over en houding tav IGB, steun van collega's, vaardigheden en uitkomstverwachtingen. Alleen onder beleidsmedewerkers VGZ is expliciet gevraagd naar steun collega's en vaardigheden, het vertrouwen in eigen kunnen om IGB actief uit te dragen, vanwege hun trekkersrol in het beleidsproces. Alleen onder portefeuillehouders, afdelingshoofden en beleidsmedewerkers VGZ is expliciet gevraagd welke belemmerende en bevorderende factoren zij ervaren, welke uitkomstverwachting van IGB zij hebben.
Of en hoe integraal beleid specifiek voor overgewicht tot stand komt is onderzocht door te vragen naar de gemeentelijke prioriteit overgewicht (3 stellingen) en naar aandacht voor het thema overgewicht binnen gemeentelijke overlegstructuren (3 stellingen). Om te achterhalen in hoeverre gemeenten rondom het gezondheidsprobleem overgewicht intersectoraal samenwerken is bij alle beleidsmedewerkers gevraagd naar de (geplande) toepassing van een twaalftal integrale interventies.

\section{Analyse}

Negatief geformuleerde vragen zijn gehercodeerd, zodat voor alle vragen een hogere score als positiever kan worden beschouwd. Voor stellingen die tezamen een samenwerkingsdeterminan conceptualiseren zijn Cronbach alpha (a) en de gemiddelde somscores berekend. Vervolgens is met behulp van een variantie-analyse gekeken of er statistisch significante verschillen zijn bij start van het begeleidingtraject tussen:

A. functionarissen in gemeenten die wel of niet begeleid willen worden bij het ontwikkelen van IGB (wel vs geen begeleiding),

B. functionarissen die wel of niet werkzaam zijn binnen het beleidsterrein volksgezondheid en welzijn (VGZ vs niet-VGZ) en

C. de verschillende gemeentelijke functieniveaus te weten het strategisch, tactisch of operationeel niveau (portefeuillehouder, afdelingshoofd of beleidsmedewerker).

De direct bevraagde determinanten zijn gedichotomiseerd en met Chi-square $\left(x^{2}\right)$ getoetst op significante verschillen tussen deelname begeleidingstraject IGB en/of VGZ-beleidsterrein Indien relevant worden ook niet significante verschillen besproken

\subsection{Resultaten}

\section{Beschrijving respondenten}

In totaal hebben 226 respondenten deelgenomen uit 32 Limburgse gemeenten, met een gemiddelde respons van 70\% per steekproefstratum (zie Tabel 1). De meeste gemeentelijke functionarissen zijn werkzaam op 2 van de volgende beleidsterreinen: Volksgezondheid en Welzijn, Ruimtelijke Ordening, Verkeer en Vervoer, Sport en Recreatie, Onderwijs en Jeugd, Sociale Zaken of anders. Portefeuillehouders, afdelingshoofden en beleidsmedewerkers met volks gezondheid in het takenpakket én eerste interne verantwoordelijke voor dit beleidsterrein zijn, ongeacht de andere beleidsterreinen die zij bedienen, ingedeeld in de categorie werkzaam in beleidsterrein VGZ (VGZ=75 versus niet-VGZ=151). Als andere beleidsterreinen worden het meest frequent genoemd sport en recreatie, onderwijs en jeugd en in iets mindere mate sociale 
Tabel 1: Respons naar type functionaris uitgesplitst naar begeleiding en beleidsterrein (absoluut en in \%)

\begin{tabular}{llllll} 
& Onderzoekspopulatie & $\begin{array}{l}\text { Begeleiding } \\
\mathbf{N}=69\end{array}$ & $\begin{array}{l}\text { Geen begeleiding } \\
\mathbf{N}=157\end{array}$ & $\begin{array}{l}\text { Respons } \\
\mathbf{N}=226\end{array}$ & $70.0 \%$ \\
\hline 1 & Portefeuillehouder VGZ & 9 & 15 & 24 & $74.9 \%$ \\
\hline 2 & Portefeuillehouder niet-VGZ & 5 & 22 & 27 & $50.0 \%$ \\
\hline 3 & Afdelingshoofd VGZ & 7 & 13 & 20 & $67.7 \%$ \\
\hline 4 & Afdelingshoofd niet-VGZ & 12 & 22 & 34 & $59.5 \%$ \\
\hline 5 & Beleidsmedewerker VGZ & 9 & 22 & 31 & $97.1 \%$ \\
\hline 6 & Beleidsmedewerker niet-VGZ & 27 & 63 & 90 & $73.5 \%$ \\
\hline
\end{tabular}

zaken. Portefeuillehouders VGZ zijn gemiddeld verantwoordelijk voor 3 andere beleidsterreinen, afdelingshoofden VGZ voor 2 en beleidsmedewerkers VGZ voor 1 ander beleidsterrein.

\section{A: Verschillen naar deelname aan begeleiding}

Binnen gemeenten die IGB begeleiding gaan ontvangen ervaren de respondenten een significant positiever gemeentelijk klimaat voor IGB dan in gemeenten die niet begeleid gaan worden. De politieke prioriteit is er hoger, er is meer draagvlak voor IGB, er zijn meer middelen beschikbaar en de rol van de media om gezondheidsbeleid te agenderen wordt belangrijker gevonden ( $46.4 \%$ vs $28.7 \%$ ). Op tactisch niveau blijkt dat er in begeleidingsgemeenten gemiddeld meer uur per week beschikbaar is voor het beleidsterrein Volksgezondheid en Welzijn (11.4 vs 8.0). Ook de samenwerking tussen de GGD en de gemeente is significant positiever in deze gemeenten. Voor de operationele samenwerkingsdeterminanten geldt dat de houding en de kennis over IGB significant positiever is in gemeenten die begeleid gaan worden (zie Tabel 2). Van alle respondenten vindt 53\% IGB bruikbaar voor de reductie van SEGV, 71\% voor de reductie van het gezondheidsprobleem overgewicht. Beleidsmedewerkers VGZ van gemeenten die begeleiding willen geven frequenter aan dat zij zelf een bijdrage kunnen leveren aan het ontwikkelen van IGB dan de collega's in andere gemeenten ( $100 \%$ vs $68.2 \%)$. Het vertrouwen in eigen kunnen is hoger en komt tot uiting via het uitleggen van IGB aan collega's met concrete voorbeelden $188.9 \%$ vs $63.6 \%$ ) en het zelf mobiliseren van collega's van andere beleidsterreinen (55.6\% vs $31.8 \%$ ).

\section{B: Verschillen naar beleidsterrein}

Respondenten werkzaam binnen het beleidsterrein VGZ zijn significant positiever over alle samenwerkingsdeterminanten ten opzichte van respondenten werkzaam buiten het beleidster rein VGZ. De politieke prioriteit is er hoger, het draagvlak en de beschikbare middelen voor IGB
Tabel 2: Samenwerkingsdeterminanten integraal gezondheidsbeleid uitgesplitst naar begeleiding en beleidsterrein lgemiddelde somscore en in \% ja)

\begin{tabular}{|c|c|c|c|c|c|c|c|c|c|c|}
\hline & \multicolumn{2}{|l|}{$\begin{array}{l}\text { Totaal } \\
\text { N }\end{array}$} & \multicolumn{2}{|c|}{$\begin{array}{l}\text { Begeleiding } \\
\text { N }\end{array}$} & \multicolumn{2}{|c|}{$\begin{array}{l}\text { Geen } \\
\text { begeleiding } \\
\text { N }\end{array}$} & \multicolumn{2}{|l|}{$\begin{array}{l}\mathrm{VGZ} \\
\mathrm{N}\end{array}$} & \multicolumn{2}{|c|}{$\begin{array}{l}\text { Niet VGZ } \\
\text { N }\end{array}$} \\
\hline \multicolumn{11}{|c|}{ Strategische samenwerkingsdeterminanten } \\
\hline $\begin{array}{l}\text { Politieke prioriteit } \\
\text { (gemid.score; } \\
\text { range: } 0-7 ; a .765 \text { ) }\end{array}$ & 226 & 2.61 & 69 & $3.07^{*}$ & 157 & $2.40^{*}$ & 75 & $3.40^{*}$ & 151 & $2.21^{*}$ \\
\hline $\begin{array}{l}\text { Gemeentelijk draagvlak/ } \\
\text { leiderschap } \\
\text { (gemid.score; range: 0-3; a .794) }\end{array}$ & 226 & 1.21 & 69 & $1.63^{* *}$ & 157 & $1.02^{* *}$ & 75 & $1.62^{*}$ & 151 & $1.00^{*}$ \\
\hline $\begin{array}{l}\text { Middelen beschikbaar } \\
\text { Respondenten VGZ (\% ja) }\end{array}$ & 49/226 & $21.7 \%$ & $23 / 69$ & $33.3 \% *$ & $26 / 157$ & $16.6 \% *$ & $23 / 75$ & $30.7 \%$ & $26 / 151$ & $17.2 \%$ \\
\hline \multicolumn{11}{|c|}{ Tactische samenwerkingsdeterminanten } \\
\hline $\begin{array}{l}\text { Steun portefeuillehouder/ } \\
\text { afdelingshoofd } \\
\text { Beleidsmedewerker VGZ } \\
\text { lgemid.score; range: } 0-2 ; \text { a . 848) }\end{array}$ & 31 & 1.22 & 9 & 1.33 & 22 & 1.18 & & & & \\
\hline $\begin{array}{l}\text { Beschikbare uren voor VGZ } \\
\text { per week } \\
\text { - Respondenten VGZ } \\
\text { - Beleidsmedewerkers VGZ } \\
\text { (gemid. aantal uren per week) }\end{array}$ & $\begin{array}{l}75 \\
31\end{array}$ & $\begin{array}{l}8.4 \\
9.0\end{array}$ & $\begin{array}{l}25 \\
9\end{array}$ & $\begin{array}{l}11.0 \\
11.4\end{array}$ & $\begin{array}{l}50 \\
22\end{array}$ & $\begin{array}{l}7.0 \\
8.0\end{array}$ & & & & \\
\hline $\begin{array}{l}\text { GGD in zetten bij } \\
\text { - beleidsontwikkeling } \\
\text { - beleidsuitvoering } \\
\text { Respondenten VGZ (\% ja) } \\
\end{array}$ & $\begin{array}{l}128 / 226 \\
122 / 226\end{array}$ & $\begin{array}{l}56.6 \% \\
54.0 \%\end{array}$ & $\begin{array}{l}38 / 69 \\
39 / 69\end{array}$ & $\begin{array}{l}55.1 \% \\
56.5 \%\end{array}$ & $\begin{array}{l}90 / 157 \\
83 / 157\end{array}$ & $\begin{array}{l}57.3 \% \\
52.9 \%\end{array}$ & $\begin{array}{l}53 / 75 \\
53 / 75\end{array}$ & $\begin{array}{l}70.7 \% * \\
70.7 \% *\end{array}$ & $\begin{array}{l}75 / 151 \\
69 / 151\end{array}$ & $\begin{array}{l}49,7 \%{ }^{*} \\
45.7 \%{ }^{*}\end{array}$ \\
\hline $\begin{array}{l}\text { Samenwerking GGD - gemeente } \\
\text { (gemid.score range: } 0-7 ; a .606 \text { ) }\end{array}$ & 226 & 1.69 & 9 & $2.23^{* *}$ & 157 & $1.45^{* *}$ & 75 & $3.01 * *$ & 151 & $1.03^{* *}$ \\
\hline \multicolumn{11}{|c|}{ Operationele samenwerkingsdeterminanten } \\
\hline $\begin{array}{l}\text { Houding } \\
\text { (gemid.score; range: } 0-4 ; \text { a . } 776 \text { ) }\end{array}$ & 226 & 2.24 & 69 & $2.52^{*}$ & 157 & $2.12^{*}$ & 75 & $2.58^{*}$ & 151 & $2.07 *$ \\
\hline $\begin{array}{l}\text { Kennis } \\
\text { (gemid.score; range: 0-2; a .675) }\end{array}$ & 226 & 1.24 & 69 & $1.43^{*}$ & 157 & $1.16^{*}$ & 75 & $1.46^{*}$ & 151 & $1.13^{*}$ \\
\hline $\begin{array}{l}\text { Steun collega's } \\
\text { Beleidsmedewerker VGZ (\% ja) }\end{array}$ & $31 / 120$ & $38.7 \%$ & 2/9 & $22.2 \%$ & $10 / 22$ & $45.5 \%$ & & & & \\
\hline $\begin{array}{l}\text { Vertrouwen in eigen kunnen } \\
\text { Beleidsmedewerker VGZ } \\
\text { lgemid.score; range: } 0-4 ; a \text {. 837) }\end{array}$ & 31 & 2.61 & 9 & 3.22 & 22 & 2.36 & & & & \\
\hline $\begin{array}{l}\text { Bevorderende en } \\
\text { belemmerende factoren } \\
\text { Respondenten VGZ } \\
\text { lgemid.score; range: } 0-20 ; a .731 \text { ) } \\
\end{array}$ & 75 & 7.94 & 25 & 9.08 & 50 & 7.38 & & & & \\
\hline${ }^{* *} \quad \mathrm{p}<.001$ & & & & & & & & & & \\
\hline
\end{tabular}


zijn groter. Men is vaker van mening dat de GGD ingezet kan worden ter ondersteuning van de beleidsontwikkeling van IGB en voor de ondersteuning bij de beleidsuitvoering. De samenwerking tussen de GGD en de gemeente wordt positiever beoordeeld en de houding en de kennis over IGB is positiever onder VGZ respondenten (zie Tabel 2). Van de beleidsmedewerkers VGZ en afdelingshoofden VGZ geeft $20 \%$ aan dat integraal beleid onderdeel is van de eigen beleidsnotities, bij de beleidsmedewerkers en afdelingshoofden niet-VGZ is dit 27\%. Van de 20 ondervraagde afdelingshoofden VGZ hebben er 14 (70\%) geen horizontaal, dus functioneel contact met de GGD. Vooral concrete projecten (82.7\%), gezondheidscijfers (73.3\%) en beleidsondersteunende overlegvormen (58.7\%) worden als bevorderende factoren ervaren bij het ontwikkelen van IGB door VGZ respondenten. Ook de wettelijk vastgestelde beleidsinstrumenten zoals de Wcpv/Wpg en de Wmo zijn van belang, waarbij de invloed van de Wmo (65.3\%) sterker als bevorderend wordt ervaren dan de Wcpv/Wpg (58.7\%).

\section{: Verschillen tussen gemeentelijke functieniveaus}

De ervaren politieke prioriteit, het gemeentelijk draagvlak voor IGB, de samenwerking tussen GGD en gemeente, de kennis van IGB en de ervaren bevorderende en belemmerende factoren van IGB hangen significant samen met de functie van de gemeentelijke actoren. Portefeuille-

\section{Tabel 3: Overgewicht en integraal gezondheidsbeleid uitgesplitst naar begeleiding en beleidsterrein (gemiddelde somscore)}

\begin{tabular}{|c|c|c|c|c|c|c|c|c|c|c|}
\hline & \multicolumn{2}{|c|}{$\begin{array}{l}\text { Totaal } \\
\text { N }\end{array}$} & \multicolumn{2}{|c|}{$\begin{array}{l}\text { Begeleiding } \\
\text { N }\end{array}$} & \multicolumn{2}{|c|}{$\begin{array}{l}\text { Geen } \\
\text { begeleiding } \\
\mathrm{N}\end{array}$} & \multicolumn{2}{|c|}{ VGZ } & \multicolumn{2}{|c|}{$\begin{array}{l}\text { Niet VGZ } \\
\text { N }\end{array}$} \\
\hline \multicolumn{11}{|c|}{ Integraal gezondheidsbeleid overgewicht } \\
\hline $\begin{array}{l}\text { Gemeentelijke prioriteit } \\
\text { overgewicht } \\
\text { (gemid.score; range: } 0-3 ; \alpha .763 \text { ) }\end{array}$ & 226 & 1.00 & 69 & $1.40^{* *}$ & 157 & $0.82^{* *}$ & 75 & $1.66^{* *}$ & 151 & $0.66^{* *}$ \\
\hline $\begin{array}{l}\text { Overgewicht in gemeentelijk } \\
\text { overleg } \\
\text { (gemid.score; range: 0-3; a.805) }\end{array}$ & 226 & 1.96 & 69 & 2.11 & 157 & 1.90 & 75 & $2.54^{* *}$ & 151 & $1.68^{* *}$ \\
\hline \multicolumn{11}{|c|}{ Interventies overgewicht binnen eigen gemeente } \\
\hline $\begin{array}{l}\text { Interventies overgewicht } \\
\text { toegepast } \\
\text { Beleidsmedewerkers VGZ } \\
\text { en niet VGZ } \\
\text { (gemid.score; range: 0-12; a .824) }\end{array}$ & 121 & 3.77 & 36 & 3.75 & 85 & 3.78 & 31 & $5.32^{* *}$ & 90 & $3.24^{* *}$ \\
\hline $\begin{array}{l}\text { Interventies overgewicht van plan } \\
\text { Beleidsmedewerkers VGZ } \\
\text { en niet VGZ } \\
\text { (gemid.score; range: } 0-12 ; \text { a } 824 \text { ) }\end{array}$ & 121 & 0.63 & 36 & 0.77 & 85 & 0.57 & 31 & 1.06 & 90 & 0.48 \\
\hline${ }^{* *} \quad \mathrm{p}<.001$ & & & & & & & & & & \\
\hline
\end{tabular}

houders (strategisch niveau) hebben hoge gemiddelde scores, gevolgd door beleidsmedewerkers (operationeel niveau), terwijl afdelingshoofden (tactisch niveau) vrijwel altijd minder positief zijn.

Casus: integraal gezondheidsbeleid overgewicht

Binnen gemeenten die gaan deelnemen aan het begeleidingstraject wordt een significant hogere prioriteit toegekend aan het gezondheidsprobleem overgewicht. De aanpak van overgewich wordt in deze gemeenten vaker gezien als een gemeentelijke taak en komt frequenter op de agenda van de gemeenteraad. Vooral binnen het beleidsterrein VGZ zijn respondenten positief. Ook komt binnen VGZ-overlegstructuren de aanpak van overgewicht significant vaker aan de orde (zie Tabel 3). Respondenten vinden de afdeling Volksgezondheid en Welzijn (96.0\%), Sport

\section{Tabel 4: Overgewichtinterventies die worden toegepast labsoluut en \%) uitgesplitst naar beleidsterrein}

\begin{tabular}{|c|c|c|c|c|c|c|}
\hline & & \multicolumn{2}{|c|}{$\begin{array}{l}\text { Beleidsmedewerker } \\
\text { VGZ }\end{array}$} & \multicolumn{2}{|c|}{$\begin{array}{l}\text { Beleidsmedewerker } \\
\text { Niet VGZ }\end{array}$} \\
\hline & $N=121$ & $\%$ & $N=31$ & $\%$ & $N=90$ & $\%$ \\
\hline \multicolumn{7}{|l|}{ Interventies overgewicht } \\
\hline $\begin{array}{l}\text { Verbod van honden op speel- } \\
\text { en sportvelden }\end{array}$ & 68 & 56.2 & 20 & 64.5 & 48 & 53.3 \\
\hline Infrastructuur nieuwe woonwijk & 64 & 52.9 & 13 & 41.9 & 51 & 56.7 \\
\hline $\begin{array}{l}\text { Realiseren van bewegings- } \\
\text { stimulerende voorzieningen }\end{array}$ & 62 & 51.2 & 26 & $83.9 * *$ & 36 & $40.0^{* *}$ \\
\hline $\begin{array}{l}\text { Via bijzondere bijstand financiële } \\
\text { tegemoetkomingen }\end{array}$ & 61 & 50.4 & 22 & $71.0^{*}$ & 39 & $43.3^{*}$ \\
\hline BOS-projecten & 56 & 46.3 & 20 & $64.5^{*}$ & 36 & $40.0^{*}$ \\
\hline $\begin{array}{l}\text { Interventies voor obese kinderen, } \\
\text { zoals realfit }\end{array}$ & 44 & 36.4 & 21 & $67.7^{* *}$ & 23 & $25.6^{* *}$ \\
\hline $\begin{array}{l}\text { Deskundigheidsbevordering } \\
\text { leerkrachten }\end{array}$ & 29 & 24.0 & 12 & $38.7^{*}$ & 17 & $18.9^{*}$ \\
\hline Herinvoeren schoolzwemmen & 22 & 18.2 & 8 & $25.8^{*}$ & 14 & $15.6^{*}$ \\
\hline $\begin{array}{l}\text { Stimuleren gezonde school- } \\
\text { kantine }\end{array}$ & 21 & 17.4 & 11 & $35.5^{* *}$ & 10 & $11.1^{* *}$ \\
\hline $\begin{array}{l}\text { Schuldhulpverlening en gezonde } \\
\text { voeding }\end{array}$ & 17 & 14.0 & 7 & 22.6 & 10 & 11.1 \\
\hline $\begin{array}{l}\text { Subsidie en certificeren sport- } \\
\text { verenigingen }\end{array}$ & 12 & 9.9 & 5 & $16.1^{* *}$ & 7 & $7.8^{* *}$ \\
\hline $\begin{array}{l}\text { Geen vergunning fastfood } \\
\text { bedrijven }\end{array}$ & 1 & 0.8 & 0 & $0.0^{*}$ & 1 & $1.1^{*}$ \\
\hline${ }^{*} \mathrm{p}<.05 \quad * * \quad \mathrm{p}<.001$ & & & & & & \\
\hline
\end{tabular}


en Recreatie (95.1\%) en Onderwijs en Jeugd (93.4\%) de belangrijkste afdelingen om overgewicht aan te pakken. De afdelingen Ruimtelijke Ordening (30.1\%), Verkeer en Vervoer $(20.8 \%$ ) en Sociale Zaken (40.7\%) worden in dit kader minder belangrijk gevonden. Van de respondenten niet-VGZ geeft $46.4 \%$ aan dat het eigen beleidsterrein geen raakvlakken heeft met het gezond heidsprobleem overgewicht. De interne samenwerking binnen de gemeentelijke organisatie rondom het gezondheidsprobleem overgewicht wordt lager gewaardeerd door de respondenten dan de externe samenwerkingsrelaties rondom dit gezondheidsprobleem Igemiddeld cijfer 4.88 vs 5.24). Beleidsmedewerkers VGZ geven, ongeacht deelname aan het begeleidingstraject, significant vaker aan dat er overgewichtinterventies worden toegepast binnen de eigen gemeente (zie Tabel 4). De meest frequent genoemde interventies, zoals hondenverbod, infrastructuur nieuwe wijk, bewegingsstimulerende voorzieningen en bijzondere bijstand komen vooral to stand via de afdelingen Ruimtelijke Ordening, Verkeer en Vervoer en Sociale Zaken. Minder dan $50 \%$ van de 12 bevraagde interventies wordt toegepast in de gemeenten (begeleiding $45 \%$ vs geen begeleiding $26 \%$. Heel weinig beleidsmedewerkers zeggen van plan te zijn om de integrale interventies te gaan toepassen in de toekomst.

\subsection{Discussie en conclusie}

De resultaten van dit onderzoek laten een consistent beeld zien van de gemeten samenwerkingsdeterminanten. Gemeenten die gaan deelnemen aan het begeleidingstraject zien zelf meer mogelijkheden om intersectoraal samen te werken om integraal gezondheidsbeleid te ontwikkelen dan gemeenten die niet begeleid willen worden. Binnen deze gemeenten en met name binnen het beleidsterrein VGZ is meer politieke prioriteit en bestuurlijk draagvlak aanwezig, zijn middelen en uren beschikbaar én is een positievere houding ten aanzien van integraal gezondheidsbeleid. Bovendien zijn meer vaardigheden en kennis aanwezig over integraal gezondheidsbeleid, algemeen en specifiek voor overgewicht. Deze 9 gemeenten lijken een betere uitgangspositie te hebben om integraal gezondheidsbeleid te ontwikkelen. Of deze betere uitgangspositie ook daadwerkelijk resulteert in integraal beleid zal vervolgonderzoek, in de vorm van een proces- en effectevaluatie van het begeleidingstraject, moeten uitwijzen. Ondanks de betere uitgangspositie wordt er geen verschil geconstateerd in de toepassing van overgewichtinterventies tussen deze gemeenten.

Opvallend is verder dat binnen de gemeentelijke organisatie de afdelingshoofden (medewerkers op het tactische niveau, zowel VGZ als niet-VGZ) het minst positief zijn over integraal gezondheidsbeleid in vergelijking met portefeuillehouders en beleidsmedewerkers. De politieke prioriteit en het draagvlak voor IGB is lager bij hen, er is beperkte kennis en men ervaart meer belemmerende factoren. Ook de samenwerking met andere beleidsterreinen, inclusief de GGD, ontbreekt vaak. Afdelingshoofden zijn vooral managers. Zij ondersteunen het beleidsproces, faciliteren en herprioriteren zo nodig het werk van de beleidsmedewerker en zijn eindverantwoordelijk voor de inzet van de beschikbare middelen. Een afdelingshoofd verdiept zich meestal niet inhoudelijk in een beleidsterrein, waardoor de kans bestaat dat de kennis over IGB beperk is en het belang van IGB voor het beleidsterrein volksgezondheid wordt onderschat. Mogelijkerwijs speelt ook de houding van de beleidsmedewerker VGZ zelf een rol en opereren zij zonder het afdelingshoofd te informeren. In het onderzoek van Jansen $(26,27)$ is aangetoond dat operationele, tactische en strategische verbindingen tussen de verschillende niches - hier beleidsterreinen - in voldoende mate aanwezig moeten zijn en met elkaar in de pas moeten blijven lopen om tot effectief beleid te kunnen komen. Of dit voor integraal gezondheidsbeleid ook zo geldt is onbekend, maar de uitgangspositie voor de ontwikkeling van integraal beleid zonder intensieve samenwerking op tactisch niveau lijkt ongunstig.

Het te starten begeleidingstraject wordt alleen aangeboden aan de 19 Zuid-Limburgse gemeenten. Tussen de 9 gemeenten die deelnemen aan het begeleidingstraject zitten 3 voormalige Hartslag Limburg gemeenten, hetgeen mogelijk hun deelname positief heeft beïnvloed. In Hartslag Limburg werd met diverse beleidsterreinen samengewerkt en werden strategische, tactische en operationele doelen in samenhang met elkaar opgesteld. Ook in Hartslag Limburg bleek de samenwerking met het tactische niveau het meest problematisch. Zo werd de rol van procesmanager belangrijk gevonden door de gemeenten, maar hieraan werd geen invulling gegeven waardoor op tactisch niveau onvoldoende mogelijkheden waren om in de randvoorwaarden te voorzien in uitvoering en continuering (26, pagina 214; 32)

Tevens blijkt dat de wettelijke verplichtingen gezien worden als een bevorderende factor voor de ontwikkeling van integraal gezondheidsbeleid, waarbij de invloed van de Wmo sterker als bevorderend wordt ervaren dan die van de Wpg. Deze visie sluit aan bij het VNG advies over publieke gezondheid (33), om gezondheid nadrukkelijker te koppelen aan maatschappelijke vraagstukken en een verbinding te maken tussen de Wmo en de Wpg. Naast deze wettelijke kaders staat het de GGD en gemeenten natuurlijk vrij om ook niet-wettelijke beleidsinstrumenten in te zetten om het gebruik van elkaars expertise en de samenwerking tussen de diverse beleidsterreinen op alle drie de niveaus te bevorderen. Zo kan ambtelijk, tactisch en bestuurlijk overleg tussen het VGZ beleidsterrein, niet-VGZ beleidsterreinen en de GGD over zowel Wpg als Wmo een prima manier zijn om gezamenlijk een integrale visie op gezondheid te ontwikkelen.

Van de 12 integrale interventies overgewicht wordt minder dan de helft toegepast in gemeenten en blijken veel integrale interventies onbekend te zijn bij beleidsmedewerkers. Functionarissen werkzaam binnen aanpalende beleidsterreinen vinden het moeilijk om overgewicht te koppelen aan eigen werkzaamheden. Als er al relaties zijn tussen beleidsactiviteiten VGZ en niet-VGZ met betrekking tot de aanpak van overgewicht worden ze door de verschillende functionarissen 
vaak niet herkend. De verschillende beleidsterreinen werken niet bewust en vanuit parallelle belangen samen aan de aanpak van overgewicht. Gebrek aan dergelijke kennis kan de ontwikkeling van integraal gezondheidsbeleid belemmeren.

Voor zover bekend is in Nederland nog weinig onderzoek gedaan naar de visie van portefeuillehouders, afdelingshoofden en beleidsmedewerkers op de mogelijkheden om binnen een gemeentelijke organisatie intersectoraal samen te werken. Externe samenwerkingsrelaties van de gemeenten zijn binnen dit onderzoek buiten beschouwing gelaten. De GGD wordt als een interne gemeentelijke relatie beschouwd daar gemeenten bestuurlijk verantwoordelijk zijn voor de GGD. Er bestaan geen gevalideerde vragenlijsten voor het meten van sectoroverstijgende samenwerking voor integraal beleid. De door ons ontwikkelde vragenlijst op basis van het conceptuele model lijkt een redelijk beeld te schetsen van de gemeentelijke intersectorale samenwerking, maar er zijn ook enkele kanttekeningen te plaatsen. De vragenlijst betreft zelfgerapporteerde bevindingen van de respondenten. Het risico op sociaal wenselijke antwoorden is nooit volledig uit te sluiten, maar wordt klein geacht daar het voornamelijk vragen waren over feitelijkheden en in mindere mate over meningen. Per gemeente was de bereidheid van de beleidsmedewerker VGZ om mailadressen aan te leveren doorslaggevend voor deelname aan het onderzoek. Van de 151 niet-VGZ respondenten gaven er 19 aan niet op de hoogte te zijn van het eigen gemeentelijke gezondheidsbeleid. Bovendien snapten zij niet waarom deelname aan het onderzoek werd gevraagd. Zij zien zelf geen raakvlakken tussen integraal gezondheidsbeleid en de eigen werkzaamheden. Dit resulteerde in onbegrip over de onderzoeksvragen. Dit kan er toe hebben geleid dat de validiteit van de vragenlijst voor deze doelgroep respondenten niet optimaal was en we dus niet precies hebben kunnen meten wat we wilden meten.

Op basis van dit onderzoek kan geconcludeerd worden dat het conceptuele model van Jansen de gemeentelijke intersectorale samenwerking goed analyseert. Gemeenten die gaan deelnemen aan het begeleidingstraject hebben een betere uitgangspositie om intersectoraal samen te werken op strategisch, tactisch en operationeel niveau en lijken beter in staat om vanuit VGZ een brug te slaan naar niet-VGZ beleidsterreinen. Een proces- en effectevaluatie van het begeleidingstraject zal moeten uitwijzen of deze gemeenten ook daadwerkelijk meer integraal beleid voor overgewicht gaan ontwikkelen. Over de invloed van het tactische niveau op de hiërarchische (verticale) en functionele (horizontale) samenwerking blijkt veel onduidelijkheid te bestaan. Daarom bevelen wij aan om aanvullend onderzoek te doen naar de rol van het afdelingshoofd bij het ontwikkelen van integraal gezondheidsbeleid. Waar op landelijk niveau vanuit het ministerie de vormgeving van integraal lokaal gezondheidsbeleid als een vanzelfsprekendheid word voorgesteld, blijkt de concrete uitwerking ervan op lokaal niveau een bijzonder lastige opgave te zijn.

\subsection{Literatuur}

1. Ministerie van Volksgezondheid Welzijn en Sport. Reactie minister op advies RVZ 2000 Den Haag, 2001

2. Ministerie van Volksgezondheid Welzijn en Sport. Kaderbrief 2007-2010 visie op gezondheid en preventie. Den Haag, 2007.

3. Ministerie van Volksgezondheid Welzijn en Sport. Gezond gedrag bevorderd. Eindrapportage van de werkgroep IBO. Interdepartementaal beleidsonderzoek, 2006-2007, nr.1. Den Haag, 2007.

4. Ministerie van Volksgezondheid Welzijn en Sport. Gezond zijn, gezond blijven. Een visie op gezondheid en preventie. Den Haag, 2007

5. Wet Collectieve Preventie Volksgezondheid (2003).

6. Wet Publieke Gezondheid (2008).

7. de Hollander AEM, Hoeymans N, Melse JM, van Oers JAM, Polder JJ. Zorg voor gezondheid - Volksgezondheid Toekomst Verkenning 2006. Bilthoven: RIVM; 2006.

8. Verweij A, den Broeder JM. Integraal gezondheidsbeleid samengevat. Bilthoven, : RIVM 2006 [cited www.nationaalkompas.nl > preventie>thema's>integraal gezondheidsbeleid 13 maart 2006].

9. Storm I, Zoest F, Broeder L. Integraal gezondheidsbeleid. Bilthoven RIVM, 2007.

10. RVZ, Onderwijsraad, Rob. Buiten de gebaande paden. Advies over intersectoraal gezondheidsbeleid, advies uitgebracht door de Raad voor de Volksgezondheid en Zorg, de Onderwijsraad en de Raad voor het openbaar bestuur. Zoetermeer, 2009.

11. Wet Maatschappelijke Ondersteuning, (2007).

12. Ministerie van Volksgezondheid Welzijn en Sport. Derde voortgangsrapportage Wmo. Den Haag, 2008.

3. Inspectie voor de GezondheidsZorg. Staat van de gezondheidszorg, 2005, deelrapport. De gemeenten zijn veel meer betrokken bij deopenbare gezondheidszorg, ze moeten nu meer zelf uitvoeren. Resultaten van het toezicht op de gemeentelijke betrokkenheid 2004. Den Haag: IGZ, 2005.

14. Kooiker S, Velden van der K. Een nuchtere kijk op gezond gedrag. Vier thema's voor gezondheidsbevordering. Den Haag: Sociaal en Cultureel planbureau, 2007.

15. Uitspraak wethouder Notulen AW werkgroep (2007).

16. Inspectie voor de GezondheidsZorg. Concept resultaten thematisch toezicht integraal beleid. 2008.

17. Inspectie voor de GezondheidsZorg. Zichtbare zorg openbare gezondheidszorg, verantwoording gemeentelijk gezondheidsbeleid. Visiedocument, 2009.

18. Zuid Limburgse gemeenten. Samen gezond! Regionale prioriteiten Volksgezondheidsbeleid Zuid Limburg 2007-2011. Maastricht, 2007. 
19. Raad voor de Volksgezondheid en Zorg. Publieke gezondheid. Advies uitgebracht door de RVZ aan de minister van VWS. Den Haag RVZ, 2006.

20. Nationaal Instituut voor Gezondheidsbevordering en Ziektepreventie. Gezondheidsbevordering in lokaal perspectief. Vaals: Zuid Limburgse gemeenten, GGD Zuid Limburg, NIGZ, 2005

21. Steenbakkers M, Pos S, ten Dam J. Een routeplanner ter ondersteuning van de ontwikkeling van lokaal integraal gezondheidsbeleid. Tijdschrift voor Gezondheidswetenschappen, 2009;87(3):42-3.

22. GGD Zuid Limburg, Universiteit Maastricht. Academische Werkplaats Publieke Gezondheid Limburg (AW). Maastricht, 2006.

23. Nijboer C, Alting D. Gezondheidswinst door gemeentelijk facetbeleid, voorbeelden die een gezond leven bevorderen, vooral bij sociaal economisch zwakkere groepen. Woerden: NIGZ, 2003.

24. Storm I, Wendel-Vos GCW, Visscher TLS, Schuit AJ. Een gezonde omgeving ter preventie van gewichtsstijging nationale en lokale mogelijkheden. Bilthoven: RIVM, 2006.

25. Bekker M. The Politics of Healthy Policies: Redesigning Health Impact Assessment to Integrate Health in Public Policy. Rotterdam: Erasmus University Rotterdam; 2007.

26. Jansen M. Mind the gap: Collaboration between practice, policy and research in local public health. Maastricht: University Maastricht; 2007.

27. Jansen M, de Vries NK, Kok G, van Oers H. Samenwerking tussen beleid, praktijk en onderzoek in de publieke gezondheidszorg: resultaten van een multipe-case studie. Tijdschrift voor gezondheidswetenschappen, 2008;86(6):296-305.

28. Steenbakkers M. www.academischewerkplaatslimburg.nl. 2007

29. Foryth DR. Leadership. Group Dynamics. 3ed ed. Belmont: Wadsworth Publishing Company; 1999

30. de Jong J, den Hartog D. Leadership as a determinant of innovative behavior. A conceptual framework. Zoetermeer Scales, 2003.

31. Wilson JL. Leadership development: working together to enchance collaboration. J Public Health Manag Pract, 2002;8(1):21-6.

32. Ruland $E$. Bestuurlijke verankering van innovaties in de openbare gezondheidszorg: lessen uit de casus Hartslag Limburg. Maastricht: Universiteit Maastricht; 2008.

33. Vereniging van Nederlandse Gemeenten. Toekomstvisie op publieke gezondheid. Maatschappelijke vraagstukken centraal - verbinden verschillende beleidsdomeinen. Den Haag: VNG, 2009. 
Hoofdstuk3

Gemeentelijke intersectorale samenwerking stimuleren:

lokale begeleiding bij het ontwikkelen van integraal gezondheidsbeleid

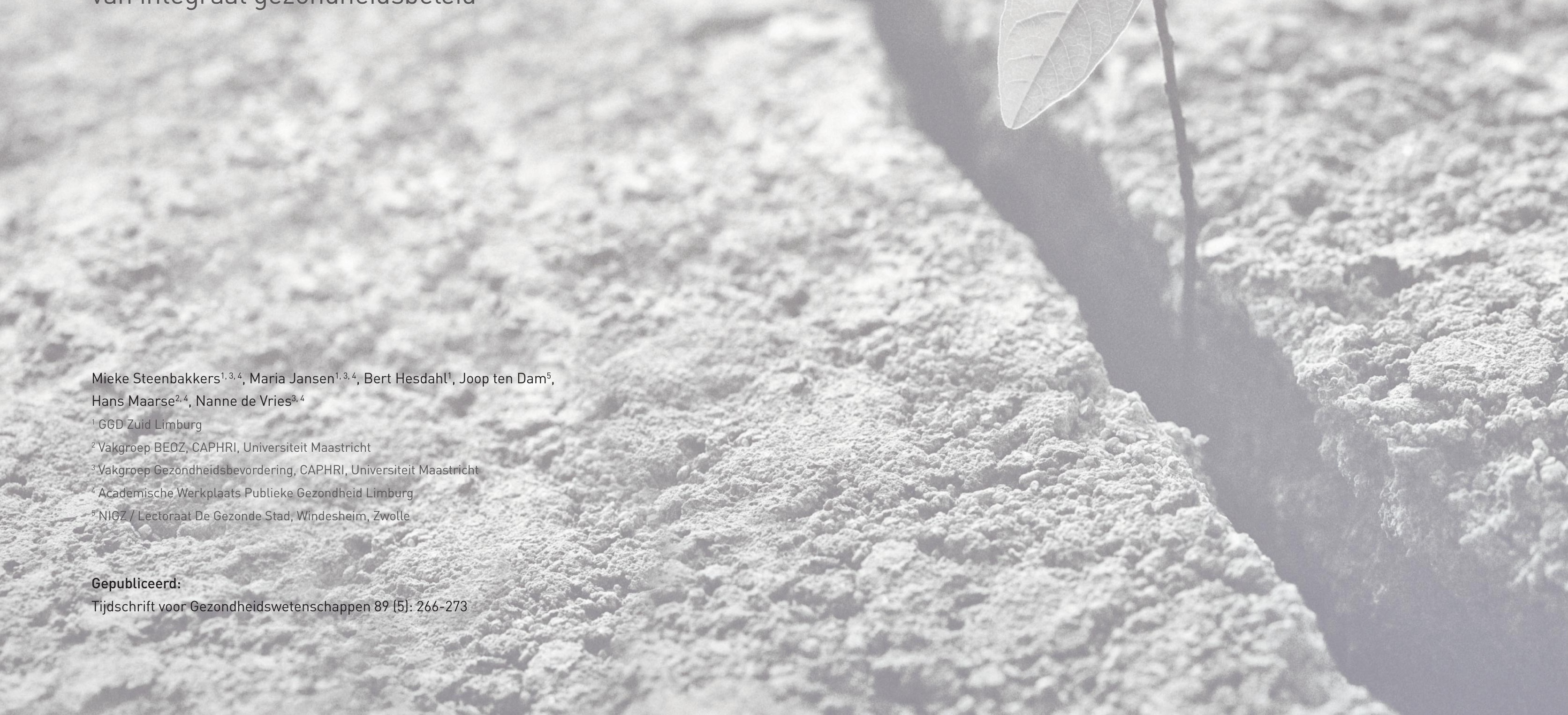




\section{Samenvatting}

In de regio Zuid-Limburg hebben gemeenten in hun regionale nota (2007-2011) integraal gezondheidsbeleid overgewicht (IGBO) geprioriteerd. Om te kunnen komen tot integraal beleid is het stimuleren van afstemming van beleid tussen verschillende beleidssectoren op zowel strategisch, tactisch als operationeel niveau gewenst. Voor integraal beleid is intersectorale samenwerking vereist. Via een begeleidingstraject hebben de GGD Zuid Limburg en het NIGZ negen Zuid-Limburgse gemeenten zowel bestuurlijk als ambtelijk ondersteund bij het bevorderen van de dialoog tussen gemeentelijke beleidssectoren. Het accent lag op het ondersteunen van de eerste fasen van het beleidsproces; van beleidsvoorbereiding naar beleidsbepaling. Via actiebegeleidend onderzoek is het begeleidingstraject gedurende 3 jaar procesmatig geëvalueerd.

Uit het onderzoek blijkt dat integraal beleid gemeentelijke bestuurders en ambtenaren wel aanspreekt, maar slechts weinig gemeenten slagen er in om intersectorale samenwerking tussen beleidssectoren te realiseren. Belangrijke knelpunten bij het ontwikkelen van integraal beleid blijken te zijn het ontbreken van voldoende kennis, competenties en bestuurlijke en ambtelijke continuïteit. Daar komt bij dat in de samenwerking tussen GGD en gemeenten een gerichte sturing op managementniveau ontbreekt. Een lange termijn perspectief en een doelgerichte aanpak met vooraf geformuleerde einddoelen zijn gewenst. Aanbevolen wordt om het gemeentelijke managementniveau VGZ actiever te betrekken bij de ontwikkeling van integraal beleid en de dialoog tussen de diverse beleidssectoren (VGZ en niet-VGZ) blijvend te stimuleren. Competentieverbeteringen bij en duidelijke samenwerkingsafspraken tussen GGD en gemeenten zijn hiervoor essentieel.

\subsection{Inleiding}

Complexe gezondheidsproblemen zoals overgewicht vragen om meer afstemming en samenwerking, met name tussen sectoren en organisaties buiten de gezondheidszorg. Het belang van integraal gezondheidsbeleid wordt (inter)nationaal sterk benadrukt (1-8). Met integraal beleid bedoelen wij beleid waarbij sectoren binnen en buiten het volksgezondheidsdomein samenwerken om gezondheidsschade te voorkómen en gezondheidswinst te realiseren (9). Intersectorale samenwerking is voorwaardenscheppend voor het formuleren van integraal beleid, maar dit blijkt in de praktijk geen eenvoudige opgave te zijn.

Gemeenten vervullen een regiefunctie bij het ontwikkelen van integraal gezondheidsbeleid en het stimuleren van intersectorale samenwerking $(10,11)$. Samenwerking niet alleen met externe partners, maar juist ook intern binnen een gemeente tussen verschillende beleidssectoren. Afstemming van beleid tussen verschillende beleidssectoren kan in gang worden gezet door actoren op strategisch, tactisch en operationeel niveau met elkaar in overleg te laten treden $(12,13)$. Binnen een gemeente betekent dit dat portefeuillehouders (strategisch niveau), afdelingshoofden (tactisch niveau) en beleidsmedewerkers (operationeel niveau) met elkaar samenwerken, zowel binnen een beleidssector (verticale samenwerking) als per niveau tussen verschillende gemeentelijke beleidssectoren, inclusief de GGD als zijnde verlengd lokaal bestuur met specifieke expertise op volksgezondheid (horizontale samenwerking) (14).

Voor het bevorderen van intersectorale samenwerking is het belangrijk dat institutionele barrières en de verschillende werkwijzen van beleidssectoren worden herkend. Door horizontaal en verticaal samen te werken kunnen geleidelijk aan grenzen tussen beleidssectoren opschuiven en vervagen zoals beschreven in het theoretisch concept over "blurring the boundaries" en werkculturen en randvoorwaarden veranderen zoals beschreven in de theorie over "institutional re-design" (15). Agendasetting en continue interactie tussen sectoren vergroten de kansen op een gezamenlijke probleemdefiniëring en -oplossing.

Om verticale en horizontale coördinatie binnen de gemeente te bevorderen, de grenzen tussen de beleidssectoren open te breken en randvoorwaarden voor samenwerking te stimuleren is een begeleidingstraject ontwikkeld. Het begeleidingstraject had als focus de aanpak van het gezondheidsprobleem overgewicht en is vanuit het samenwerkingsconvenant "Gezondheidsbevordering in lokaal perspectief" door de GGD Zuid Limburg en het NIGZ ontwikkeld (16). Vanuit de Academische Werkplaats Publieke Gezondheid Limburg $(17,18)$ is dit lokale begelei- 
dingstraject "Integraal gezondheidsbeleid overgewicht" (IGBO) procesmatig geëvalueerd. In dit artikel wordt op basis van de procesdata en de gerealiseerde eindproducten per gemeente aangegeven of het begeleidingstraject heeft geleid tot intersectorale samenwerking en de ontwikkeling van integraal gezondheidsbeleid.

\subsection{Methode}

\section{Begeleidingstraject "Integraal gezondheidsbeleid overgewicht"}

Doel van het begeleidingstraject was het bevorderen van samenwerking tussen de verschillende beleidssectoren in een gemeente gericht op de aanpak van overgewicht, en het vergroten van de competenties van gemeentelijke beleidsmedewerkers volksgezondheid (VGZ) en gezondheidsbevorderaars van de GGD. Voor dit doel zijn de volgende strategieën als onderdeel van het begeleidingstraject ontwikkeld:

1. Pleitbezorging en agendasetting. Hiertoe zijn regionale startconferenties voor bestuurders en ambtenaren gehouden om de urgentie van het gezondheidsprobleem overgewicht in de regio Zuid-Limburg inzichtelijk te maken en de noodzaak van intersectoraal samenwerking te duiden. Drie intersectorale beleidsinstrumenten zijn toegelicht: de determinantenbeleidsscreening (DBS), de quickscan facetbeleid (QSF) en de checklist gezondheidseffectscreening (GES) (19-23).

2. Informatie en training. Hiertoe is een masterclass opgezet voor gemeentelijke beleidsmedewerkers VGZ en gezondheidsbevorderaars van de GGD. Tijdens de masterclass is het gebruik van de beleidsinstrumenten DBS, QSF en GES geillustreerd (24). Om deelname te bevorderen is deze scholing drie keer regionaal uitgevoerd. Om de gezondheidsbevorderaars voor te bereiden op hun beleidsadviserende taak binnen het begeleidingstraject zijn er 4 interne trainingen uitgevoerd.

3. Voorzien in randvoorwaarden. Voor deelname aan het begeleidingstraject was bestuurlijke goedkeuring noodzakelijk en een ambtelijke inzet van ongeveer 2 uur per week vereist.

4. Actief leren en samen doen. Per gemeente is er een lerend trio gevormd bestaande uit de beleidsmedewerker VGZ, een gezondheidsbevorderaar vanuit de GGD en een medewerker van het NIGZ. Gedurende 30 maanden hebben zij gezamenlijk gewerkt aan de beleidsvoorbereiding (prioritering/agendasetting van het gezondheidsprobleem overgewicht binnen andere beleidssectoren), de beleidsbepaling (beleidsformulering en besluitvorming) en, voor gemeenten die hieraan zijn toegekomen, ook aan de beleidsuitvoering (25). Concreet betekende dit: a. een analyse maken van de lokale gezondheidssituatie, het politieke en bestuurlijke krachtenveld en de lopende projecten binnen een gemeente:

b. een intakegesprek voeren met beleidsmedewerker VGZ en portefeuillehouder VGZ om aangrijpingspunten voor de aanpak van overgewicht te bespreken;

c. regelmatig overleg om het beleidsplan uit te schrijven met behulp van een van de drie beleidsinstrumenten waarin doelstelling, gewenste resultaten, te ondernemen activiteiten, de samenwerkingspartners en het tijdspad zijn weergegeven en zo mogelijk de uitvoering van het beleidsplan te begeleiden;

d. via zeven intervisiebijeenkomsten met de trio-leden van de negen gemeenten zijn kennis en vaardigheden met elkaar gedeeld en werd het traject inhoudelijk aangestuurd.

\section{Actiebegeleidend onderzoek}

Om inzicht te krijgen in het proces dat in iedere gemeente is doorlopen en om praktijkervaringen direct bruikbaar te maken voor andere gemeenten is gekozen voor actiebegeleidend onderzoek (26-29). Dit soort onderzoek kent twee functies, namelijk het evalueren van de uitgevoerde activiteiten en het mede beïnvloeden van de voortgang van het proces, waarbij de betrokken onderzoeker een dubbelrol vervult. Voor het verzamelen van relevante informatie zijn er per gemeente logboeken bijgehouden door de beleidsmedewerker VGZ, de gezondheidsbevorderaar en de NIGZ-er om inzicht te verkrijgen in alle stappen die zijn ondernomen. Belangrijke elementen in het logboek waren tijdsinvestering, aantal contacten buiten de beleidssector VGZ en met de GGD, de gemaakte onderlinge afspraken en bevorderende of belemmerende factoren voor het begeleidingstraject zoals wisseling van portefeuillehouder, beleidsmedewerker of gezondheidsbevorderaar. Tevens zijn verslagen gemaakt van ambtelijke en bestuurlijke overleggen, trainingen, intervisiebijeenkomsten inclusief bilaterale besprekingen over de tussentijdse vorderingen. Tijdens de intervisiebijeenkomsten heeft de onderzoeker de tussentijdse bevindingen uit de procesevaluatie teruggekoppeld, is de voortgang per gemeente besproken, zijn onderling ervaringen uitgewisseld, heeft training van adviesvaardigheden plaatsgevonden en zijn gemeenten geadviseerd over mogelijke vervolgstappen voor integraal beleid op basis van de vorderingen en eerdere onderzoeksbevindingen (14).

\section{Analyse}

De verzamelde onderzoeksdata zijn geordend naar inzet en betrokkenheid van de actoren op strategisch, tactisch en operationeel niveau en naar determinanten (cursief) die relevant zijn voor sectoroverstijgende samenwerking (12). Per niveau en voor alle niveaus gezamenlijk is er een optelsom gemaakt van de geturfde inzet en betrokkenheid per gemeente (aan/afwezig) (zie Tabel 1) 
Op strategisch niveau dient de portefeuillehouder VGZ politieke prioriteit te geven aan integraal beleid. Indien integraal gezondheidsbeleid overgewicht is opgenomen in de gemeentelijke nota gezondheidsbeleid is dit als een indicator van politieke prioriteit beschouwd. Gemeentelijk draagvlak/leiderschap is gekoppeld aan: het beleidsplan bespreken met de portefeuillehouder VGZ, bepleiten integraal beleid in het college van Burgemeester \& Wethouders (B\&W), goedkeuring van beleidsplan door het college van B\&W, aanwezigheid van de portefeuillehouder VGZ bij portefeuillehoudersoverleggen over integraal beleid, en het bepleiten van integraal beleid overgewicht in de gemeenteraad. Op strategisch niveau zijn de beschikbare middelen van cruciaal belang. Een indicator hierbij is menskracht/geld verkregen via andere beleidssectoren dan VGZ Tussentijds vertrek van de portefeuillehouder VGZ wordt als belemmerende factor beschouwd.

Op tactisch niveau dienen afdelingshoofden VGZ managementsteun te geven aan het samenwerkingsproces. Hieraan is voldaan als het beleidsplan en de voortgang zijn besproken in de afdelings- en bilaterale overleggen met het afdelingshoofd. De geïnvesteerde uren van de beleidsmedewerker VGZ in het begeleidingstraject wordt gezien als een bevorderende factor wat betreft de beschikbare capaciteit. Het aantal contactmomenten tussen de gezondheidsbevorderaar en de beleidsmedewerker VGZ én het aantal betrokken niet-VGZ beleidssectoren zegt iets over de openheid en de cultuur van de organisatie.

Op operationeel niveau dienen beleidsmedewerkers VGZ te beschikken over voldoende kennis en een positieve houding ten aanzien van intersectorale samenwerking en integraal beleid. Een indicator hiervoor is deelname van beleidsmedewerkers aan de intervisiebijeenkomsten. Het schrijven van het beleidsplan door de beleidsmedewerker VGZ en het werken met beleidsinstrumenten zoals de DBS en GES zeggen iets over de vaardigheden. Als belemmerende factor is tussentijdse wisseling van personeel (bij gemeente, GGD en NIGZ) meegewogen, evenals het niet vervangen van de beleidsmedewerker VGZ tijdens ziekte of zwangerschapverlof lomgerekend naar het totaal aantal beschikbare maanden van de beleidsmedewerker VGZ gedurende het begeleidingstraject).

Tevens is per gemeente gekeken naar de gerealiseerde eindproducten van het begeleidingstraject. Concreet betekent dit, conform de beleidscyclus, of er gezamenlijk is gewerkt aan de prioritering/agendasetting van het gezondheidsprobleem overgewicht binnen andere beleidssectoren, dat beleidsvoorbereidende stappen zijn ondernomen om de preventie van overgewich vast te leggen in beleidsdocumenten van andere sectoren en dat vastgesteld beleid is geïmplementeerd. Door de onderzoeker zijn de gerealiseerde eindproducten van het begeleidingstraject per gemeente voorzien van een score, waarbij score 1 staat voor afwezigheid van beleid en score 5 voor integraal beleid dat wordt geïmplementeerd:
$0=$ voortijdig stoppen van het begeleidingstraject

1 = geen concrete integrale eindproducten;

$2=$ een eindproduct in de fase van beleidsvoorbereiding

$3=$ een eindproduct in de fase van afgeronde beleidsformulering, klaar voor besluitvorming in college van B\&W of gemeenteraad

$4=$ een eindproduct in de fase van genomen besluit door college van B\&W of gemeenteraad, klaar voor implementatie;

$5=$ een eindproduct in de fase van implementatie (zie Tabel 1).

Om te achterhalen of er een relatie bestaat tussen geleverde inzet en betrokkenheid vanuit een gemeente gedurende het begeleidingstraject en het gerealiseerde eindproduct is de score van het eindproduct gekoppeld aan de totaalscore qua inzet en betrokkenheid (zie Grafiek 1). Hierbij is de veronderstelling dat meer inzet en betrokkenheid vanuit verschillende institutionele niveaus leidt tot meer integraal gezondheidsbeleid.

\subsection{Resultaten}

Het toegepaste begeleidingstraject heeft in zes gemeenten geleid tot concrete (integrale) eindproducten. In de fase van beleidsvoorbereiding (score 2) hebben drie gemeenten in samenwerking met andere beleidssectoren gezorgd dat gezondheid werd opgenomen in een masterplan voor een krachtwijk, dat bewegingsstimulering aandacht kreeg in een gemeentelijk fietsplan en een herstructureringsplan en dat overgewicht als thema is opgenomen in een leefbaarheidsagenda in combinatie met activiteiten vanuit het Nationaal Actieplan Sport en Bewegen (NASB) In nauwe samenwerking tussen de beleidssectoren Ruimtelijke Ordening (RO) en VGZ is in één gemeente een gezondheidstoets voor overgewicht ontwikkeld, welke ingezet kan worden als extra checklist bij de uitwerking van RO plannen. Deze nieuwe beleidsprocedure zit in de fase van besluitvorming (score 3). Binnen één andere gemeente is er gewerkt aan het verkrijgen van bestuurlijke toestemming voor deelname van de beleidsmedewerker VGZ aan een multidisciplinaire projectgroep in de ontwerpfase van bestemmingsplannen. Deze nieuwe beleidsprocedure is afgerond en geaccordeerd door het college van B\&W (score 4). Om tijdens deze multidisciplinaire overleggen de dialoog met andere beleidssectoren aan te kunnen gaan is in samenwerking met de GGD een handleiding ontwikkeld voor de beleidsmedewerker VGZ. In één gemeente zijn er extra cursussen 'Goede voeding hoeft niet veel te kosten' door de sector Sociale Zaken ingekocht en geïmplementeerd (score 5). Het ging hier om uitbreiding van bestaand beleid. Voor drie eindproducten zijn middelen (menskracht en/of budgetten) vanuit andere beleidssectoren ingezet. Het traject heeft in één gemeente niet tot concrete eindproducten geleid (score 1). Er is wel veel tijd in dit traject geïnvesteerd, maar door wisseling van portefeuillehouder en beleids- 
Tabel 1: Inzet en betrokkenheid bij integraal gezondheidsbeleid overgewicht (IGBO) naar samenwerkingsdeterminanten op

\begin{tabular}{|c|c|c|c|c|c|c|c|c|c|c|}
\hline Deelnemende gemeenten (A t/m I) aan begeleidingstraject IGBO & A & $\begin{array}{l}\text { B } \\
>\end{array}$ & $\begin{array}{r}\mathbf{c} \\
0 \text { inw }\end{array}$ & D & $\mathbf{E}$ & $\begin{array}{c}\mathbf{F} \\
\text { tusse }\end{array}$ & $\begin{array}{r}\mathbf{G} \\
000 \text { en }\end{array}$ & $\begin{array}{r}\text { H } \\
0 \text { inw }\end{array}$ & $\begin{array}{r}\text { I } \\
<10.000 \\
\text { inw }\end{array}$ & Totaalscore \\
\hline \multicolumn{11}{|l|}{ Samenwerkingsdeterminanten op strategisch niveau ( $\mathrm{N}=8$ ) } \\
\hline $\begin{array}{l}\text { Politieke prioriteit } \\
\text { - IGBO in lokale nota volksgezondheidsbeleid }(\mathrm{ja}=1 / \mathrm{nee}=0 \text { ) }\end{array}$ & 1 & 1 & 1 & 1 & 1 & 1 & 1 & 0 & 1 & $8 \times$ score ja \\
\hline 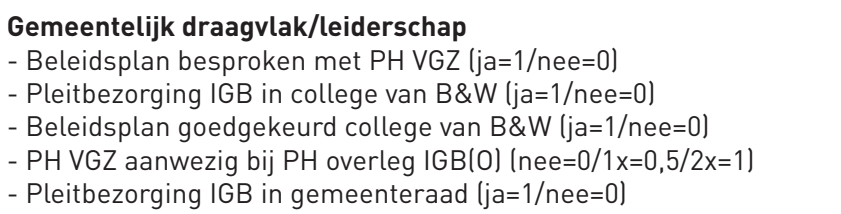 & $\begin{array}{l}1 \\
0 \\
0 \\
1 \\
1\end{array}$ & $\begin{array}{l}1 \\
0 \\
0 \\
1 \\
0\end{array}$ & $\begin{array}{l}0 \\
0 \\
0 \\
0 \\
0\end{array}$ & $\begin{array}{l}1 \\
1 \\
1 \\
0 \\
1\end{array}$ & $\begin{array}{l}1 \\
1 \\
1 \\
1 \\
1\end{array}$ & $\begin{array}{r}1 \\
0 \\
0 \\
0,5 \\
0\end{array}$ & $\begin{array}{l}1 \\
0 \\
0 \\
1 \\
0\end{array}$ & $\begin{array}{r}1 \\
0 \\
0 \\
0,5 \\
0\end{array}$ & $\begin{array}{r}1 \\
1 \\
0 \\
0,5 \\
1\end{array}$ & $\begin{array}{r}8 \times \text { score ja } \\
3 \times \text { score ja } \\
2 \times \text { score ja } \\
4 \times=>2 \times \text { aanwezig } \\
4 \times \text { score ja }\end{array}$ \\
\hline $\begin{array}{l}\text { Middelen beschikbaar } \\
\text { - Via intersectorale samenwerking }(j a=1 / \text { nvt-nee }=0)\end{array}$ & 0 & 1 & 0 & 1 & 0 & 0 & 0 & 0 & 1 & $3 \times$ score ja \\
\hline Wisseling portefeuillehouder VGZ $(j a=0 /$ nee $=1)$ & 1 & 1 & 1 & 1 & 1 & 0 & 0 & 1 & 1 & $7 \times$ score nee \\
\hline subtotaal & 5 & 5 & 2 & 7 & 7 & 2,5 & 3 & 2,5 & 6,5 & \\
\hline \multicolumn{11}{|l|}{ Samenwerkingsdeterminanten op tactisch niveau ( $N=7$ ) } \\
\hline $\begin{array}{l}\text { Management steun } \\
\text { - Bespreken beleidsplan in afdelingsoverleg (ja= } 1 / \mathrm{nee}=0) \\
\text { - Bespreken voortgang traject bilateraal overleg hoofd }(\mathrm{ja}=1 / \mathrm{nee}=0)\end{array}$ & $\begin{array}{l}0 \\
0\end{array}$ & $\begin{array}{l}0 \\
1\end{array}$ & $\begin{array}{l}0 \\
0\end{array}$ & $\begin{array}{l}1 \\
1\end{array}$ & $\begin{array}{l}1 \\
1\end{array}$ & $\begin{array}{l}1 \\
1\end{array}$ & $\begin{array}{l}0 \\
1\end{array}$ & $\begin{array}{l}0 \\
1\end{array}$ & $\begin{array}{l}1 \\
1\end{array}$ & $\begin{array}{l}4 \times \text { score ja } \\
7 \times \text { score ja }\end{array}$ \\
\hline $\begin{array}{l}\text { Beschikbare capaciteit }(\leq 50=0,33 / 50-100=0,66 / \geq 100=1) \\
\text { - Uren geïnvesteerd in begeleidingstraject door gemeente } \\
\text { - Uren geïnvesteerd in begeleidingstraject door GGD } \\
\text { - Uren geïnvesteerd in begeleidingstraject door NIGZ }\end{array}$ & $\begin{array}{l}0,33 \\
0,66 \\
0,66\end{array}$ & $\begin{array}{l}0,33 \\
0,33 \\
0,66\end{array}$ & $\begin{array}{l}0,33 \\
0,66 \\
0,33\end{array}$ & $\begin{array}{r}0,66 \\
1 \\
0,66\end{array}$ & $\begin{array}{r}0,66 \\
1 \\
0,33\end{array}$ & $\begin{array}{l}0,66 \\
0,66 \\
0,33\end{array}$ & $\begin{array}{l}0,66 \\
0,33 \\
0,33\end{array}$ & $\begin{array}{l}0,33 \\
0,66 \\
0,33\end{array}$ & $\begin{array}{l}0,33 \\
0,66 \\
0,33\end{array}$ & $\begin{array}{l}5 x \leq 50 \text { uur } \\
2 x \leq 50 \text { uur } \\
6 x \leq 50 \text { uur }\end{array}$ \\
\hline $\begin{array}{l}\text { Cultuur van de organisatie } \\
\text { - Aantal contacten gemeente - GGD }(\leq 20=0,5 />20=1) \\
\text { - Aantal andere interne beleidssectoren betrokken }(<5=0,5 / \geq 5=1)\end{array}$ & $\begin{array}{l}0,5 \\
0,5\end{array}$ & $\begin{array}{r}1 \\
0,5\end{array}$ & $\begin{array}{l}1 \\
1\end{array}$ & $\begin{array}{l}1 \\
1\end{array}$ & $\begin{array}{l}1 \\
1\end{array}$ & $\begin{array}{l}1 \\
1\end{array}$ & $\begin{array}{r}0,5 \\
1\end{array}$ & $\begin{array}{l}0,5 \\
0,5\end{array}$ & $\begin{array}{r}0,5 \\
1\end{array}$ & $\begin{array}{r}4 x \leq 20 \text { contacten } \\
3 x<5 \text { terreinen }\end{array}$ \\
\hline subtotaal & 2,66 & 3,83 & 3,33 & 6,32 & 7 & 5,66 & 3,83 & 3,33 & 4,83 & \\
\hline \multicolumn{11}{|l|}{ Samenwerkingsdeterminanten op operationeel niveau ( $\mathrm{N}=9$ ) } \\
\hline $\begin{array}{l}\text { Kennis en houding } \\
\text { - Deelname } 7 \text { intervisiebijeenkomsten }(\leq 4=0,5 />4=1)\end{array}$ & 1 & 0,5 & 0,5 & 1 & 1 & 0,5 & 0,5 & 0,5 & 0,5 & $6 x \leq 4 x$ aanwezig \\
\hline $\begin{array}{l}\text { Vaardigheden } \\
\text { - Schrijven beleidsplan door gemeente }(\mathrm{j} a=1 / \mathrm{nee}=0) \\
\text { - Tussentijds aanscherpen IGB beleidsplan }(\mathrm{ja}=1 / \text { nee }=0 \text { ) } \\
\text { - Inzet beleidsinstrument DBS } \\
\text { - Inzet beleidsinstrument GES }\end{array}$ & $\begin{array}{l}1 \\
0 \\
1 \\
0\end{array}$ & $\begin{array}{l}0 \\
1 \\
1 \\
0\end{array}$ & $\begin{array}{l}0 \\
1 \\
0 \\
1\end{array}$ & $\begin{array}{l}1 \\
0 \\
0 \\
1\end{array}$ & $\begin{array}{l}1 \\
1 \\
0 \\
1\end{array}$ & $\begin{array}{l}0 \\
1 \\
1 \\
0\end{array}$ & $\begin{array}{l}0 \\
1 \\
0 \\
1\end{array}$ & $\begin{array}{l}0 \\
0 \\
1 \\
0\end{array}$ & $\begin{array}{l}0 \\
0 \\
1 \\
0\end{array}$ & $\begin{array}{r}3 \times \text { score ja } \\
5 \times \text { score ja } \\
5 \times \text { DBS } \\
4 \times \text { GES }\end{array}$ \\
\hline $\begin{array}{l}\text { Belemmerende factoren } \\
\text { - Wisseling beleidsmedewerker VGZ }(\mathrm{j} a=0 / \text { nee }=1) \\
\text { - Wisseling gezondheidsbevorderaar GGD }(\mathrm{ja}=0 / \text { nee }=1) \\
\text { - Vervanging bij ziekte/zwanger bij gemeente }(\mathrm{j} a=1 / \mathrm{nee}=0) \\
\text { - Beschikbare mnd voor traject bij de gemeente }(\leq 15=0,5 />15=1)\end{array}$ & $\begin{array}{l}0 \\
0 \\
0 \\
1\end{array}$ & $\begin{array}{l}0 \\
0 \\
0 \\
1\end{array}$ & $\begin{array}{l}1 \\
1 \\
0 \\
1\end{array}$ & $\begin{array}{l}0 \\
0 \\
0 \\
1\end{array}$ & $\begin{array}{l}0 \\
1 \\
0 \\
1\end{array}$ & $\begin{array}{l}1 \\
1 \\
0 \\
1\end{array}$ & $\begin{array}{r}0 \\
1 \\
0 \\
0,5\end{array}$ & $\begin{array}{r}1 \\
0 \\
0 \\
0,5\end{array}$ & $\begin{array}{l}0 \\
1 \\
0 \\
1\end{array}$ & $\begin{array}{r}3 \times \text { score nee } \\
5 \times \text { score nee } \\
0 \times \text { score ja } \\
\text { Gemid. } 17 \mathrm{mnd}\end{array}$ \\
\hline subtotaal & 4 & 3,5 & 5,5 & 4 & 6 & 5,5 & 4 & 3 & 3,5 & \\
\hline Alle samenwerkingsdeterminanten opgeteld $(\mathrm{N}=24)$ & 11,7 & 11,3 & 10,8 & 17,3 & 20 & 13,7 & 10,8 & 8,8 & 14,8 & \\
\hline Ordening eindproducten begeleidingstraject (score $1 \mathrm{t} / \mathrm{m}$ 5) & 2 & 5 & 2 & 3 & 4 & 1 & 0 & 0 & 2 & \\
\hline
\end{tabular}

- Uren geïnvesteerd in begeleidingstraject door NIGZ

- Aantal contacten gemeente - $G G D(\leq 20=0,5 />20=1$,

- Aantal andere interne beleidssectoren betrokken $\mid<5=0,5 / \geq 5=1\}$ strategisch, tactisch en operationeel niveau 
medewerker lukte het niet het beleidsplan goed uit te werken. Twee gemeenten zijn voortijdig gestopt met het begeleidingstraject (score 0) wegens tijdgebrek van de beleidsmedewerker VGZ en onvoldoende draagvlak bij zowel het afdelingshoofd VGZ als de nieuwe portefeuillehouder VGZ voor het uitgewerkte beleidsplan (zie Tabel 1).

Qua inzet en betrokkenheid op strategisch niveau onderscheiden gemeenten zich door elementen zoals pleitbezorging door de portefeuillehouder VGZ binnen het college van B\&W of gemeenteraad en goedkeuring van het beleidsplan in het college van B\&W (zie Tabel 1). De portefeuillehouder verbindt zich hierdoor expliciet aan het begeleidingstraject en probeert binnen zijn/haar gemeente draagvlak te verkrijgen voor een meer integrale aanpak van overgewicht. In vrijwel alle gemeenten is integraal werken opgenomen in de lokale nota volks gezondheid en het beleidsplan besproken met de portefeuillehouder VGZ. Wisseling van portefeuillehouder VGZ gedurende het begeleidingstraject heeft de betrokkenheid bij het traject negatief beïnvloed, kennis over relevantie van integraal werken is verloren gegaan. Voor de GGD kreeg het begeleidingstraject interne prioriteit omdat integraal werken aan overgewicht in de gemeentelijke regionale nota en het samenwerkingsconvenant met het NIGZ was opgenomen. Hierdoor werd het mogelijk om eigen organisatiemiddelen in te zetten in het begeleidingstraject, waardoor gezondheidsbevorderaars van de GGD hun competenties op het gebied van integraal werken konden vergroten. De GGD heeft haar deelname aan het begeleidingstraject vermeld in jaarrapportages aan gemeenten en in externe nieuwsbrieven. Het traject is niet besproken in het MT of interne nieuwsbrieven van de GGD.

Op tactisch niveau lijkt, naast bilateraal overleg met het afdelingshoofd, het bespreken van het beleidsplan in het afdelingsoverleg VGZ een onderscheidend element. Bespreking in het afdelingsoverleg vergroot het interne draagvlak voor het beleidsplan en geeft de beleidsmede werker ondersteuning bij de uitvoering van het plan. Qua beschikbare capaciteit is er door de gemeentelijke beleidsmedewerkers VGZ gemiddeld 52,5 uur geïnvesteerd in het totale begeleidingstraject, door de gezondheidsbevorderaars van de GGD gemiddeld 73,5 uur en de NIGZ-ers 46,8 uur. Ondanks het feit dat vooraf een inzet van 2 uur per week van de beleidsmedewerker is gevraagd, heeft het merendeel van de gemeenten minder dan 50 uur geïnvesteerd in het traject (range: 33-85 uur). Er zijn grote verschillen in openheid en organisatiecultuur tussen de gemeenten. Gedurende het begeleidingstraject hebben de trio-leden (beleidsmedewerker VGZ, gezondheidsbevorderaar GGD en NIGZ-er) gemiddeld 23 keer (range: 12 - 35 contacten) onderling contact gehad over het traject. Vooral de GGD heeft veel tijd geïnvesteerd in het stimuleren en ondersteunen van de beleidsmedewerker VGZ bij het intern concretiseren van het beleids plan. Door het traject zijn in alle gemeenten andere beleidssectoren betrokken bij het gezondheidsprobleem overgewicht, bij zes gemeenten is contact geweest met 5 of meer andere beleidsafdelingen (range: 1-10 sectoren) (zie Tabel 1). In vrijwel alle gemeenten zijn met steun van het begeleidingstraject door de beleidsmedewerker VGZ contacten gelegd met beleidssectoren uit de 'harde sector', zoals RO, Verkeer en Vervoer en gemeentewerken: sectoren waarmee de beleidsmedewerker VGZ voorheen geen werkrelatie had. Binnen de gemeenten heeft gedurende het begeleidingstraject op tactisch niveau geen functiewisseling plaatsgevonden.

Op operationele niveau zijn inzet en betrokkenheid van de beleidsmedewerker VGZ essentieel. Het beleidsplan is in vier gemeenten geschreven door de beleidsmedewerker VGZ, in de andere vijf gemeenten door de GGD en het NIGZ. In zes gemeenten is het plan tussentijds door het trio aangescherpt en/of bijgesteld op basis van nieuwe inzichten. Zo werd bijvoorbeeld een voorstel tot bestuurlijke toetsing van alle gemeentelijke beleidsdocumenten op gevolgen voor de volksgezondheid in de praktijk niet haalbaar geacht waardoor aanpassing noodzakelijk was. Alle gemeenten hebben ter ondersteuning een beleidsinstrument gebruikt om het beleidsplan uit te schrijven; vijf gemeenten maakten gebruik van de DBS om voor de belangrijkste determinanten van overgewicht (voeding en bewegen) gericht te kijken met welke beleidssectoren er samengewerkt kon worden en vier gemeenten van een GES om in ontwikkeling zijnde beleidsplannen te beoordelen op mogelijke gezondheidseffecten. De QSF is niet gebruikt door de gemeenten omdat de GGD/NIGZ bij de start van het begeleidingstraject reeds een analyse hadden gemaakt van de lokale gezondheidssituatie, het politieke en bestuurlijke krachtenveld en de lopende projecten. Deze informatie is gebruikt bij het uitwerken van het lokale beleidsplan. De gekozen beleidsinstrumenten zijn bij het uitwerken van het beleidsplan vrijwel niet gebruikt. Het accent lag toen op het aangaan van de interne dialoog. Gedurende de begeleidingsperiode zijn zes beleidsmedewerkers VGZ en vier gezondheidsbevorderaars van de GGD van functie gewisseld, hetgeen de aanwezigheid bij de intervisiebijeenkomsten en de betrokkenheid bij het traject negatief heeft beïnvloed. Elke wisseling gaf verlies aan kennis en vaardigheden over intersectoraal werken en integraal beleid. Met aftrek van het aantal maanden dat er geen vervanging was bij functiewisseling van de beleidsmedewerker VGZ en reguliere verlofperioden (feestdagen en vakantie), resulteerde dit in een effectieve inzet van gemiddeld 17 maanden in plaats van de 30 geplande begeleidingsmaanden (zie Tabel 1). Uit de intervisiebijeenkomsten bleek verder dat de trio-leden het moeilijk vonden om een gezondheidsprobleem zoals overgewicht te verbinden aan andere gemeentelijke beleidsprioriteiten.

De gegevens over inzet en betrokkenheid bij integraal beleid overgewicht (zie Tabel 1) zijn zowe voor de determinanten per strategisch, tactisch en operationeel niveau, als voor alle determinanten tezamen opgeteld. De totaalscore is gerelateerd aan de ordening van de eindproducten (zie Grafiek 1). Als de inzet en betrokkenheid evenwichtig is, dat wil zeggen als er zowel op strategisch, tactisch en operationeel niveau door de gemeente en de GGD is geïnvesteerd in intersectoraal samenwerken, lijkt dit de ontwikkelmogelijkheden van integraal beleid te vergroten (zie score gemeente $\mathrm{D}$ en $\mathrm{E}$ ). 


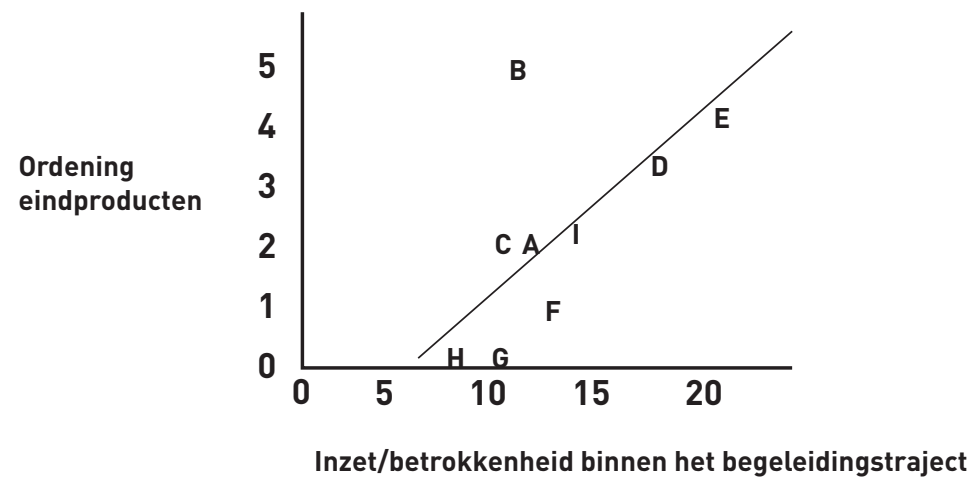

Grafiek 1: Totaalscore van inzet en betrokkenheid binnen het begeleidingstraject IGBO versus de score voor het eindproduct per deelnemende gemeente $(\mathrm{A} t / \mathrm{m} I)$

\subsection{Discussie en conclusie}

\section{Intersectorale samenwerking}

Via een begeleidingstraject zijn gemeenten ondersteund bij het bevorderen van de dialoog tussen gemeentelijke beleidssectoren. Vooral de gemeentelijke beleidsmedewerker VGZ is de interne dialoog met andere beleidssectoren aangegaan en op zoek gegaan naar nieuwe intersectorale beleidsafstemming. Echter, het veranderen van interne werkstructuren en -processen in termen van "institutional re-design" is moeilijk te realiseren wanneer draagvlak bij en steun hiervoor bij het management en bestuur ontbreekt. In zes gemeenten heeft het toegepaste begeleidingstraject geleid tot concrete (integrale) eindproducten. Dit waren voornamelijk kleine beleidswijzigingen die zonder veel ruchtbaarheid en financiële consequenties in onderlinge samenwerking tussen de betrokken beleidssectoren konden worden gerealiseerd. Om te kunnen komen tot integraal gezondheidsbeleid is het stimuleren van een continue interactie tussen beleidssectoren essentieel $(12,13,15)$. Bij de start van het begeleidingstraject zijn afspraken gemaakt over de gewenste ureninzet van de beleidsmedewerker VGZ, maar deze inzet is in geen enkele gemeente gerealiseerd. Portefeuillehouders VGZ spraken hun goedkeuring uit voor het ontwikkelen van integraal beleid, maar droegen dit niet altijd actief uit binnen het college van B\&W en/of de gemeenteraad. Daarnaast vond er in beperkte mate verticale communicatie plaats binnen het beleidsterrein VGZ en hebben de GGD en het NIGZ de afdelingshoofden VGZ niet expliciet uitgenodigd tot deelname aan het begeleidingstraject. De mate waarin zij betrokken zijn werd overgelaten aan de portefeuillehouder en de beleidsmedewerker De afwezigheid van het tactische niveau kan de interne intersectorale samenwerking en de concretisering van de beleidsplannen negatief hebben beïnvloed $(12,14)$. Gedurende het be- geleidingstraject bleek het moeilijk om met andere sectoren gezamenlijk beleidsdoelstellingen te formuleren en te implementeren en werden inzet en betrokkenheid van het management gemist om grenzen tussen beleidssectoren te laten vervagen zoals met "blurring the boundaries" wordt beoogd.

De verkregen extra ondersteuning vanuit het NIGZ is met name ingezet bij de start van het traject om de urgentie van het gezondheidsprobleem politiek te agenderen en om beleidsmedewerkers te ondersteunen bij het uitwerken van het beleidsplan. Op dit operationele niveau is veel inhoudelijke kennis overgedragen over de drie integrale beleidsinstrumenten in relatie to het gezondheidsprobleem overgewicht (24). Gedurende het traject bleek echter dat vooral het persoonlijke contact met andere beleidssectoren een verbindende factor was voor intersectorale samenwerking en in veel mindere mate het gebruikte beleidsinstrument. Functiewisselingen van portefeuillehouders VGZ en of beleidsmedewerkers VGZ bemoeilijkten het interne samenwerkingsproces. Verder blijkt dat het verbinden van een gezondheidsprobleem aan gemeentelijke beleidsprioriteiten om andere competenties en vaardigheden vraagt van GGDgezondheidsbevorderaars. Het accent ligt hierbij meer op de rol van procesbegeleider dan op de huidige rol van interventie-uitvoerder $(27,30)$.

\section{Onderzoek in de praktijk}

Voor zover bekend is in Nederland nog weinig onderzoek gedaan naar gemeentelijke intersectorale samenwerking met betrekking tot gezondheid. Met de resultaten van dit kleinschalige exploratieve onderzoek proberen wij meer zicht te krijgen in de mogelijkheden om via gemeentelijke intersectorale samenwerking de ontwikkeling van integraal gezondheidsbeleid te stimuleren. Echter, het onderzoek heeft een aantal beperkingen waardoor de bevindingen voorzichtig geïnterpreteerd moeten worden. Allereerst wordt verondersteld dat er sprake is van enige mate van onderrapportage met betrekking tot het aantal intersectorale contacten en de geïnvesteerde uren. De logboeken zijn uitsluitend ingevuld door beleidsmedewerkers VGZ en er is geen informatie verzameld bij portefeuillehouders VGZ en afdelingshoofden VGZ. Ook de dubbelrol van de onderzoeker bij actiebegeleidend onderzoek kan het proces hebben beïnvloed. Zo maakte de onderzoeker tijdens de intervisiebijeenkomsten problemen in de voortgang van het begeleidingstraject inzichtelijk en bespreekbaar, stimuleerde zij leerprocessen en het geven van feedback $(29,31)$, en diende zij tegelijkertijd objectief te evalueren. Tenslotte vond deelname aan het begeleidingstraject plaats op vrijwillige basis, hetgeen mogelijk heeft geresulteerd in een selectiebias. Uit eerder onderzoek van Steenbakkers e.a. (14) blijkt dat de negen ZuidLimburgse gemeenten die deelnamen aan het begeleidingstraject bij aanvang van het traject een betere uitgangspositie hadden om intersectoraal samen te werken dan de gemeenten die niet meededen. De resultaten van dit onderzoek laten echter zelfs bij gemeenten met een goede startpositie een beperkt resultaat zien. 


\section{Aanbevelingen}

Uit vergelijkend internationaal onderzoek blijkt, dat voor een succesvolle implementatie van integraal gezondheidsbeleid de volgende factoren essentieel zijn: sterk leiderschap op bestuurlijk niveau, een heldere visie op gezondheid en duidelijke doelstellingen, werken met nieuwe organisatiestructuren, inzet vanuit verschillende institutionele niveaus en voldoende middelen $(6,15)$. Het Zuid-Limburgse begeleidingstraject laat zien dat intersectorale samenwerking veel investering vraagt en dat er geen garantie is op succes te weten het realiseren van integraal gezondheidsbeleid. De opzet en uitwerking van het door de GGD en het NIGZ uitgevoerde begeleidingstraject bleek achteraf onvoldoende krachtig te zijn om daadwerkelijk het interne gemeentelijke beleidsproces wezenlijk te beïnvloeden en breed gemeentelijk draagvlak te verwerven. Door de vele wisselingen op zowel strategisch als operationeel niveau is vee kennis verloren gegaan. Sterk leiderschap op bestuurlijk niveau ontbrak, organisatiestructuren zijn niet bijgesteld en er zijn vooraf geen harde afspraken gemaakt over inzet van middelen (menskracht/geld) en betrokkenheid vanuit verschillende beleidssectoren en institutionele niveaus. Wij bevelen dan ook aan om het tactische niveau actiever te betrekken bij de ontwikkeling van integraal gezondheidsbeleid, daar het managementniveau binnen gemeenten een continue en invloedrijke organisatielaag is (32). Omdat volksgezondheid geen dominan gemeentelijk beleidsterrein is en bij geen enkel beleidsterrein hoog op de agenda staat blijft het stimuleren van een continue dialoog tussen de beleidssector VGZ en andere beleidssectoren belangrijk. Beleidsveranderingen komen in het algemeen slechts incrementeel dus hee geleidelijk tot stand. Dit geldt ook voor integraal gezondheidsbeleid. Gezondheid is hierbij geen doel op zich maar een middel om het beleid van andere sectoren te verbeteren. Om dit te kunnen realiseren bevelen wij aan om de samenwerking tussen de beleidssector VGZ en de GGD niet vrijblijvend te laten zijn, maar duidelijke afspraken te maken over ieders inzet, taken en verantwoordelijkheden op strategisch, tactisch en operationeel niveau. De GGD zou zichzelf nadrukkelijker als regionaal kenniscentrum moeten positioneren om de gemeentelijke beleidscyclus actief te voeden en de ontwikkeling van lokaal integraal beleid mee vorm te geven. Het is aan de directie en het management van de GGD om te voorzien in competentieverbeteringen van gezondheidsbevorderaars en het maken van duidelijkere samenwerkingsafspraken met gemeenten. Kortom: intersectorale samenwerking vraagt om stevige investeringen van gemeenten én GGD.

\subsection{Literatuur}

1. Goumans M. Innovations in a Fuzzy Domain: Healthy Cities and (health) Policy Development in the Netherlands and the United Kingdom. Maastricht University Maastricht; 1998.

2. WHO. Ottawa charter for health promotion. Health Promotion International 1986;1:iii-v.

3. RVZ. Publieke gezondheid. Advies uitgebracht door de RVZ aan de minister van VWS. Den Haag 2006.

4. Inspectie voor de Gezondheidszorg. Concept resultaten thematisch toezicht integraal beleid. 2008.

5. Kickbusch K, McCann W, Sherbon T. Adelaide revisited: from healthy public policy to Health in All Policies. Health Promotion International 2008;23(1):Editorial.

6. St-Pierre L. Governance tools and Framework for Health in All Policies: National Collaborating centre for Healthy Public Policy2009.

7. RVZ, Onderwijsraad, Rob. Buiten de gebaande paden. Advies over intersectoraal gezondheidsbeleid, advies uitgebracht door de Raad voor de Volksgezondheid en Zorg, de Onderwijsraad en de Raad voor het openbaar bestuur. Zoetermeer, 2009.

8. ten Dam J. Gezond Beleid. Tijdschrift voor gezondheidswetenschappen 2010;88(5):228-31.

9. Storm I, Zoest F, Broeder L. Integraal gezondheidsbeleid: theorie en toepassing. Bilthoven RIVM, 2007

10. Ministerie van Volksgezondheid Welzijn en Sport. Gezond zijn, gezond blijven. Een visie op gezondheid en preventie. Den Haag, 2007.

11. Wet Publieke Gezondheid, (2008)

12. Jansen M. Mind the gap: Collaboration between practice, policy and research in local public health. Maastricht: University Maastricht; 2007.

13. Jansen M, de Vries NK, Kok G, van Oers H. Samenwerking tussen beleid, praktijk en onderzoek in de publieke gezondheidszorg: resultaten van een multipe-case studie. Tijdschrift voor gezondheidswetenschappen 2008;86(6):296-305.

14. Steenbakkers $\mathrm{M}$, Jansen $\mathrm{M}$, Maarse $\mathrm{H}$, de Vries $\mathrm{N}$. Lokaal integraal gezondheidsbeleid: intersectorale samenwerking vanuit het perspectief van gemeenten. Tijdschrift voor gezondheidswetenschappen 2010;88(3):136-43.

5. de Leeuw E, McNess A, Stagnitti K, Crisp B. It's research, Jim, but not as we know it .. Acting at the Nexus. Integration of Research, Policy and Practice. Geelong: Deakin University, 2007.

16. Nationaal Instituut voor Gezondheidsbevordering en Ziektepreventie Gezondheidsbevordering in lokaal perspectief. Vaals: Zuid Limburgse gemeenten, GGD Zuid Limburg NIGZ, 2005.

17. GGD Zuid Limburg, Universiteit Maastricht. Academische Werkplaats Publieke Gezondheid Limburg (AW). Maastricht, 2006. 
18. Jansen M, van de Goor I. De gemeente als partner in de Academische Werkplaats Publieke Gezondheid:vantoeschouwer naarstakeholder.Tijdschriftvoorgezondheidswetenschappen 2008;86(6):321-7.

19. van Herten L, Pernis M, van Reeuwijk J, Vrij J, Reijneveld M. Instrumenten voor facetbeleid. Projectverslag. Leiden/Bilthoven, 2003.

20. van Herten L, van Reeuwijk J, Pernis M, Koornstra A. Hoe zet je facetbeleid rond gezondheid op? De beterende hand / instrumenten voor de openbare gezondheidszorg. G2004;1:26-7.

21. TNO en RIVM. Handboek Determinantenbeleidsscreening. Leiden/Bilthoven/Utrecht, 2004.

22. TNO en RIVM. Handboek Quick scan facetbeleid. Leiden/Bilthoven/Utrecht, 2004.

23. TNO en RIVM. Handboek checklist gezondheidseffectscreening. Leiden/Bilthoven/Utrecht, 2004

24. NIGZ, Limburg GZ, gemeenten Z-L. Masterclass Integraal Gezondheidsbeleid. Geleen: GGD Zuid Limburg, 2006.

25. Hoogerwerf A. Beleid, processen en effecten. In: Hoogerwerf A, Herweijer M, editors. Overheidsbeleid Een inleiding in de beleidswetenschap. Alphen aan de Rijn: Samson; 1998. p. 17-36.

26. Koelen MA, van den Ban W. Health education and Health promotion. Wageningen: Academic Publishers; 2004.

27. Saan H, de Haes W. Gezond effect bevorderen: het organiseren van effectieve gezondheidsbevordering. Woerden: NIGZ; 2005.

28. Boeije H. Analyseren in kwalitatief onderzoek. Denken en doen. Den Haag: Boom onderwijs: 2006.

29. Wagemakers MAE. Actiebegeleidend onderzoek ter bevordering van intersectorale samenwerking en bewonersparticipatie. De ervaringen met het wijkgericht gezondheidswerk in Eindhoven. Tijdschrift voor gezondheidswetenschappen 2007;85(1):23-31.

30. Hesdahl B, Boot N, Hoeijmakers M, Linssen E, Vermeer A. GB-spiraal GGD Zuid Limburg "samen gezond verder" een integrale toepassing. Nationaal Congres Volksgezondheid; 8 april 2009; Rotterdam, 2009.

31. DiClemente CC, Marineilli AS, Singh M, Bellino LE. The Role of Feedback in the Process of Health Behavior Change. Am J Health Behav 2001;25:217-27.

32. Mintzberg H. Mintzberg over Management. De wereld van onze organisaties. 13e druk ed. Amsterdam/Antwerpen: Business Contact; 2004. 


\section{Hoofdstuk 4}

Sturing op integraal gezondheidsbeleid: de rol van het gemeentelijke management 


\section{Samenvatting}

Landelijk wordt steeds vaker het belang van integraal gezondheidsbeleid voor gemeentelijk gezondheidsbeleid benadrukt. Intersectorale samenwerking zowel op strategisch (bestuurders), tactisch (managers) als operationeel niveau (beleidsmedewerkers) binnen een gemeentelijke organisatie wordt gezien als een voorwaardenscheppend proces om te komen tot formulering van integraal beleid. Uit eerder onderzoek blijkt dat binnen een gemeente het tactische niveau (het management) niet of nauwelijks betrokken is bij intersectorale samenwerking. Via semigestructureerde interviews bij 13 gemeentelijke managers VGZ is daarom de rol van afdelingsmanagers VGZ binnen het gemeentelijke beleidsproces ten aanzien van intersectorale samenwerking en integraal gezondheidsbeleid geëxploreerd.

De resultaten van dit onderzoek laten zien dat de afdelingsmanagers VGZ niet afwijzend staan tegenover intersectorale samenwerking binnen hun gemeente en het formuleren van integraal gezondheidsbeleid. Zij voelen zich vooral hiërarchisch verantwoordelijk voor volksgezondheid. De inhoudelijke betrokkenheid is in de praktijk echter zeer beperkt en gedelegeerd. Gemeentelijke managers vragen aan de GGD haar expertise op het vlak van intersectorale samenwerking en integraal beleid explicieter kenbaar te maken. Zonder gerichte inhoudelijke sturing is het moeilijk gezondheid structureel een plek te geven binnen andere beleidsterreinen. Als verlengd lokaal bestuur ligt hier een uitdaging voor de GGD om dit beleidsproces inhoudelijk te voeden. De GGD wordt aangeraden veel actiever op te treden in het (on)gevraagd adviseren van het gemeentelijke lijnmanagement. De zeer beperkte beschikbare beleidscapaciteit binnen gemeenten voor gezondheid versterkt de noodzaak tot gerichte beleidsondersteuning vanuit de GGD.

\subsection{Inleiding}

Aansturing van de publieke gezondheid vindt zowel op landelijk als lokaal niveau plaats. Landelijk worden beleidsmatige kaders geschetst en lokaal worden deze kaders verder uitgewerkt en afgestemd op maatschappelijke problemen. Decentralisatie geeft gemeenten mogelijkheden tot regievoering en kansen voor het ontwikkelen van integraal (gezondheids)beleid, in lokaal en/of regionaal verband(1). Hierbij is integraal gezondheidsbeleid geen doel op zich, maar wel een aanbevolen manier om complexe gezondheidsproblemen aan te pakken (2-4). Kenmerkend voor integraal gezondheidsbeleid is dat sectoren binnen en buiten het volksgezondheidsdomein samenwerken om gezondheidsschade te voorkómen en gezondheidswinst te realiseren (5). Intersectorale samenwerking is belangrijk voor het bevorderen van integraal gezondheidsbeleid $(6,7)$. Om intersectorale samenwerking binnen een gemeente tot stand te brengen dienen actoren op strategisch (bestuurders), tactisch (managers) en operationeel (beleidsmedewerkers) zowel functioneel (horizontaal) als hiërarchisch (verticaal) met elkaar in overleg te treden (8). Binnen de gemeentelijke beleidscyclus betekent dit dat met name in de fasen van de beleidsvoorbereiding en de beleidsbepaling samenwerking en afstemming met andere gemeentelijke beleidsterreinen noodzakelijk is. Gemeenten geven hierbij aan dat samenwerking met maatschappelijke partners soms makkelijker tot stand komt dan de interne samenwerking met verschillende gemeentelijke beleidsterreinen (9). De fase van beleidsvoorbereiding kenmerkt zich door het stellen van prioriteiten en agendasetting van een gezondheidsprobleem en het via diverse bronnen verzamelen, analyseren en bediscussiëren van informatie. De fase van beleidsbepaling bestaat uit het formuleren van beleid en de besluitvorming hierover. De gemeenteraad stelt het beleidsplan vast, bepaalt welke doelen men wil bereiken en hoeveel geld daarvoor beschikbaar is. Het is daarna aan het college van burgemeester en wethouders (B\&W) en aan het ambtelijke apparaat om dat beleid ten uitvoer te brengen en zo de beoogde doelen te realiseren en te evalueren (de fasen van de beleidsimplementatie respectievelijk beleidsevaluatie) (10)

Voor het formuleren van integraal gezondheidsbeleid is het belangrijk dat een continue (in)formele interactie tussen verschillende beleidsterreinen en op de drie functieniveaus wordt gestimuleerd $(8,11,12)$. Zo dienen beleidsmedewerkers van verschillende gemeentelijke beleidsterreinen samen beleidsplannen op te stellen en gezondheidsdoelen te formuleren. Tevens is het belangrijk aan te geven via welke aanpak deze doelen bereikt kunnen worden $(8,12-16)$. Gemeentelijke managers vervullen in deze processen vanuit hun formele leidinggevende positie verschillende rollen $(17,18)$. Enerzijds zijn zij verantwoordelijk voor het hiërarchisch leiding geven aan een afdeling (lijnmanagement). Anderzijds zijn zij functioneel verantwoordelijk voor het adequaa uitvoeren van afdelingstaken en het inhoudelijk aansturen van complexe beleidsprocessen in onderlinge samenhang (programmamanagement). Soms worden deze inhoudelijke managementtaken zonder hiërarchische beslissingsbevoegdheid gedelegeerd binnen een afdeling, 
maar de manager blijft eindverantwoordelijk en stuurt op hoofdlijnen het proces aan. Een manager vervult een belangrijke rol bij de beoordeling van verschillende beleidsalternatieven bij het bepalen of via een bestuurs- of directieopdracht een maatschappelijk probleem wordt vertaald in een opdrachtformulering tot beleid. Is er een opdrachtformulering tot beleid, dan zal een manager idealiter zijn beleidsmedewerkers stimuleren, coachen en faciliteren om via een interactief proces met interne en externe stakeholders te komen tot een concept beleidsformulering welke vervolgens de procedure ingaat om bestuurlijk te worden vastgesteld. De invloed van de manager wordt als sterker ervaren in kleinere gemeenten. Hoe groter de gemeente en de kans op een fulltime bestuurlijke aanstelling, des te prominenter de plaats van een bestuurder binnen een gemeente en daarmee tevens diens invloed op dergelijke ambtelijke processen $(10,19)$. Uit onderzoek blijkt dat binnen een gemeentelijke organisatie afdelingsmanagers het minst positief zijn over integraal gezondheidsbeleid. Vooral op het niveau van de bestuurder (strategisch) en beleidsmedewerker (operationeel) worden verbindingen gelegd met andere beleidsterreinen en de GGD, maar op tactische niveau ontbreekt vaak deze samenwerking (9). Deze gesignaleerde beperkte betrokkenheid van het gemeentelijke management bij het initiëren van intersectorale samenwerking en het formuleren van integraal gezondheidsbeleid was aanleiding om de rol van de afdelingsmanager met volksgezondheid (VGZ) in de portefeuille nader te onderzoeken. Hierbij stonden de volgende onderzoeksvragen centraal:

- Kan een afdelingsmanager met VGZ in portefeuille de formulering en ontwikkelmogelijkheden van integraal gezondheidsbeleid en de vereiste intersectorale samenwerking binnen een gemeente bevorderen?

- Welke ondersteunende rol kan een GGD volgens afdelingsmanagers met VGZ in portefeuille vervullen in dit beleidsproces?

Belangrijke kanttekening hierbij is dat er binnen gemeenten meestal geen aparte afdeling volksgezondheid aanwezig is en er dus ook géén uniforme functie 'manager VGZ' bestaat. De portefeuille VGZ is vaak onderdeel van een bredere afdeling zoals een afdeling Welzijn, Samenleving of Inwonerszaken hetgeen uiteraard ook invloed kan hebben op de functie-invulling van de betreffende manager.

\subsection{Methode}

\section{Onderzoekspopulatie/interviews}

Er zijn semi-gestructureerde interviews gehouden met afdelingsmanagers met VGZ in de portefeuille van Zuid-Limburgse gemeenten. Geïnterviewden dienden minimaal 2 jaar in functie te zijn als VGZ leidinggevende binnen een gemeente. In totaal hebben 13 afdelingsmanagers deelgenomen aan het onderzoek, waarvan 8 afkomstig uit gemeenten die door de GGD Zuid Limburg begeleid werden bij de vormgeving van integraal beleid en 5 uit gemeenten zonder deze begeleiding. De grootte van de deelnemende gemeenten varieerde van meer dan 90.000 inwoners en tevens centrumgemeenten $(N=3)$, tot $50.000-20.000$ inwoners $(N=2)$ en minder dan 20.000 inwoners $(N=8)$. Er is geïnterviewd tot saturatie was bereikt. Geen van de benaderde afdelingsmanagers heeft deelname aan het onderzoek geweigerd.

Volgens de literatuur kunnen veranderingsprocessen vanuit het tactisch niveau worden bevorderd door vier factoren $(8,20,21)$, namelijk het:

- geven van managementsteun

- beschikbaar stellen van capaciteit;

- veranderen van de aanwezige cultuur binnen een afdeling.

- en doorvoeren van een passende manier van leiderschap.

In de interviews zijn deze vier factoren besproken met de managers en is tevens expliciet gevraagd naar de rol van de GGD bij gemeentelijke intersectorale samenwerking en de ondersteuning bij integraal gezondheidsbeleid. Daarnaast is geïnventariseerd hoeveel FTE er binnen gemeenten beschikbaar is voor de afdeling waar de portefeuille VGZ is ondergebracht en de gemeentelijke organisatie als geheel.

\section{Analyse interviews}

De interviews zijn op tape opgenomen, uitgeschreven, handmatig gecodeerd en geanalyseerd. Alle uitspraken van de managers/afdelingsmanagers VGZ over de ontwikkelmogelijkheden van integraal gezondheidsbeleid en gemeentelijke intersectorale samenwerking zijn geïnventariseerd en vervolgens gecodeerd in 26 items, onderverdeeld naar de factoren managementsteun, capaciteit, cultuur en leiderschap (zie Tabel 1). De benamingen van de verschillende gemeentelijke afdelingen waar VGZ onderdeel van is, gecombineerd met de beschikbare ambtelijke capaciteit per gemeente zijn geordend op basis van inwonersaantallen (zie Tabel 2). Daarna is op basis van uitspraken per afdelingsmanager geturfd welke items binnen de betreffende gemeente van toepassing waren. De codering is uitgevoerd door twee onafhankelijke onderzoekers. De uitspraken van de afdelingsmanagers VGZ ten aanzien van de ondersteunende rol van de GGD 
bij intersectorale samenwerking zijn aanvullend geanalyseerd. Bij het bespreken van de resultaten zijn de uitspraken van de afdelingsmanagers cursief weergegeven.

\subsection{Resultaten}

\section{Managementsteun}

Onder managementsteun zijn de volgende items ingedeeld: een manager VGZ kijkt zelf positief tegen integraal beleid aan en stimuleert bewust intersectorale samenwerking binnen zijn/haar afdeling, de manager ervaart bestuurlijk draagvlak van de portefeuillehouder VGZ, integraal beleid is vertaald in gemeentelijke beleids- en begrotingsdocumenten en de manager prioriteert en faciliteert intersectoraal werken (zie Tabel 1).

Tien managers vinden een integrale kijk op gezondheid belangrijk: “Eigenlijk kan niemand tegen integraal werken zijn." Intersectorale samenwerking wordt binnen de eigen afdeling door acht managers gestimuleerd bijvoorbeeld door: "Mensen uit te dagen tot integraal werken. Laa mensen ervaren dat het een meerwaarde heeft, dan worden ze intrinsiek gemotiveerd om het ook te gaan doen." Ook ervaart de helft bestuurlijk draagvlak: "Bestuurlijk draagvlak is geen discussiepunt, waar het wel om gaat is dat we veel concreter onze gezondheidsdoelen formuleren." Zeven managers geven aan dat het belangrijk is dat integraal werken tot uiting komt in beleidsdocumenten zoals een stadsvisie, een programmabegroting, programmalijnen/-sturing, kwartaalrapportages en integrale beleidsnota's: "Het is belangrijk om opgenomen te zijn in een programmalijn, dan werk je meer vanuit een thematiek en zijn programmamanagers inhoudelijk verantwoordelijk. Werken vanuit een afdeling stimuleert verkokering, terwijl een programmanager juist actief zelf gaat shoppen binnen de totale organisatie." Binnen de eigen afdeling VGZ prioriteren vijf managers intersectorale samenwerking door bijvoorbeeld "mensen bilateraal of in overleg te bevragen of ze aan bepaalde verbindingen hebben gedacht." Als voorbeeld van het faciliteren van interne samenwerking wordt genoemd: "Wij hebben goede overlegstructuren binnen de organisatie. We organiseren bijvoorbeeld al jaren thema-avonden waarvoor medewerkers van verschillende afdelingen worden uitgenodigd."

\section{Beschikbare capaciteit}

Beschikbare capaciteit is gekoppeld aan de volgende items: de beleidsmedewerker VGZ beschikt over de beleidscompetenties om signalen van buiten intern te vertalen, Wpg-taken in combinatie met Wmo-taken uit te voeren waardoor de beleidsmedewerker al VGZ sectoroverstijgend kan werken, contactvaardig te zijn op meerdere hiërarchische niveaus en VGZ kennis te vertalen naar andere thema's. Waarbij verondersteld wordt dat senioriteit van de beleidsmedewerker VGZ een brede visie op VGZ en intersectorale samenwerking met niet-VGZ beleidsterreinen bevordert. Ook de beschikbare FTE voor VGZ is een item l $\leq 0,5$ FTE wordt als onvoldoende beschouwd) en het feit of er aanvullende beleidscapaciteit beschikbaar is voor intersectoraal werken (zie Tabel 1).

Tabel 1: Items benoemd als zijnde van invloed op intersectorale samenwerking binnen een gemeente doo gemeentelijke afdelingsmanagers VGZ $(N=13)$, geordend naar frequentie benoeming

Beïnvloeding intersectorale samenwerking vanuit tactisch niveau

\section{Managementsteun}

- manager zelf positief over integraal beleid

- stimuleren intersectorale samenwerking binnen afdeling door manager

- ervaren bestuurlijk draagvlak bij portefeuillehouder VGZ

- integraal komt tot uiting in beleids- en begrotingsdocumenten

- intersectoraal werken krijgt prioriteit binnen afdeling VGZ

- intersectoraal werken wordt gefaciliteerd door manager

\section{Beschikbare capaciteiten:}

- noodzakelijke beleidscompetentie: signalen van buiten intern vertalen

- Wpg en Wmo taken uitgevoerd door beleidsmedewerker VGZ

- beschikbare FTE voor VGZ $(\leq 0.5 \mathrm{FTE})$

- noodzakelijke beleidscompetentie: contactvaardig op meerdere niveaus

- noodzakelijke beleidscompetentie: VGZ kennis vertalen naar thema's

- senioriteit aanwezig bij beleidsmedewerker VGZ

- intersectorale samenwerking met niet-VGZ wordt toegepast door afdeling

- aanvullende beleidscapaciteit beschikbaar voor intersectoraal werken

\section{Cultuur van de organisatie:}

- samenwerking GGD verloopt via beleidsmedewerker VGZ

- er is een positief klimaat voor intersectorale samenwerking

- manager wil zelf meer samenwerking met GGD

- beleidsmedewerkers fysiek dicht bij elkaar zitten

- cultuuromslag nodig binnen gemeente

- herziening interne gemeentelijke werkstructuur geweest

- manager met uitvoerende beleidstaken

- loopt een herziening interne gemeentelijke werkstructuur - wordt gewerkt met matrixstructuur

Leiderschap/stijl van manager VGZ:

- hiërarchisch leidinggeven (lijnmanagement)

- inhoudelijk (aan)sturen (programmamanagement)

- manager betrokken bij gemeentelijk begeleidingstraject $(\mathrm{N}=8)$

De kunde om signalen van buiten intern te vertalen is door elf managers benoemd als een noodzakelijke beleidscompetentie bij beleidsmedewerkers VGZ. "Het begint met een grondhouding. In hoeverre ben je geïnteresseerd in het werk van je buurman". Tien beleidsmedewerkers 
voeren naast Wpg- ook Wmo-taken binnen de eigen beleidsafdeling uit. Negen beleidsmedewerkers VGZ beschikken over $\leq 0.5$ FTE voor VGZ gecombineerd met Wmo-taken. "Het grote excuus dat wordt gebruikt is 'daar heb ik geen tijd voor'. Het kan soms wel een valide reden zijn, maar ik wil als manager zo vroeg mogelijk in het proces weten welke vraag er ligt." De portefeuille VGZ is bij gemeenten ondergebracht bij gemeentelijke afdelingen met diverse benamin gen en een breed takenpakket. Ook de beleidsmedewerker VGZ heeft vaak meerdere beleidsterreinen in zijn/haar takenpakket. In vergelijking met de beschikbare capaciteit van de totale

Tabel 2: Benamingen gemeentelijke afdeling waar VGZ onderdeel van is, gecombineerd met totale beschikbare formatie binnen een gemeente in relatie tot het inwonersaantal, voor de afdeling waar VGZ is onderformatie binnen een gemeente in relatie tot het

\begin{tabular}{|c|c|c|c|c|c|c|c|}
\hline \multirow[t]{2}{*}{$\begin{array}{l}\text { Naam gemeentelijke } \\
\text { afdeling waar } \\
\text { VGZ is ondergebracht }\end{array}$} & \multirow[t]{2}{*}{$\begin{array}{r}\text { Aantal } \\
\text { inwoners } \\
1-1- \\
2009\end{array}$} & \multirow[t]{2}{*}{$\begin{array}{r}\text { FTE } \\
\text { gemeente } \\
\text { totaal }\end{array}$} & \multirow[t]{2}{*}{\begin{tabular}{|r|} 
FTE \\
gemeente \\
per \\
1000 \\
inwoners
\end{tabular}} & \multirow[t]{2}{*}{$\begin{array}{r}\text { FTE } \\
\text { afdeling } \\
\text { incl. } \\
\text { VGZ }\end{array}$} & \multirow[t]{2}{*}{$\begin{array}{r}\text { FTE } \\
\text { afdeling } \\
\text { per } \\
1000 \\
\text { inwoners }\end{array}$} & \multicolumn{2}{|c|}{$\begin{array}{r}\text { FTE } \\
\text { Beleidsmede- } \\
\text { werker belast } \\
\text { met VGZ beleid }\end{array}$} \\
\hline & & & & & & VGZ & $\begin{array}{r}\text { plus } \\
\text { Wmo }\end{array}$ \\
\hline $\begin{array}{l}\text { Sector Samenleving: } \\
\text { afdeling Welzijn \& Zorg }\end{array}$ & 118.004 & 1300 & 11 & $\begin{array}{l}35 \\
10\end{array}$ & $\begin{array}{r}0.3 \\
0.09\end{array}$ & 0.8 & \\
\hline $\begin{array}{l}\text { Afdeling } \\
\text { Maatschappelijke Ontwikkeling: } \\
\text { team Onderwijs Cultuur, } \\
\text { Welzijn en Sport }\end{array}$ & 95.691 & 821 & 9 & 42 & 0.2 & 0.6 & \\
\hline Afdeling Welzijn & 89.671 & 1150 & 13 & 36 & 0.4 & 0.5 & 0.5 \\
\hline $\begin{array}{l}\text { Sector Samenleving: } \\
\text { afdeling Zorg }\end{array}$ & 48.334 & 359 & 7 & $\begin{array}{l}87 \\
19 \\
\end{array}$ & $\begin{array}{l}1.8 \\
0.4\end{array}$ & 0.4 & 0.6 \\
\hline Afdeling Beleid en Strategie & 29.742 & 200 & 7 & 15 & 0.5 & 0.5 & 0.5 \\
\hline Afdeling Breed Welzijn & 19.744 & 86 & 4 & 6 & 0.3 & 0.2 & \\
\hline $\begin{array}{l}\text { Afdeling Maatschappelijke } \\
\text { Ondersteuning }\end{array}$ & 17.099 & 116 & 7 & 30 & 1.8 & 0.2 & 0.5 \\
\hline $\begin{array}{l}\text { Afdeling Welzijn, Zorg } \\
\text { en Onderwijs }\end{array}$ & 16.696 & 115 & 7 & 9 & 0.5 & 0.2 & 0.5 \\
\hline Afdeling Welzijn & 15.851 & 71 & 5 & 3 & 0.2 & 0.2 & 0.5 \\
\hline Afdeling Burger en bestuur & 13.531 & 101 & 8 & 16 & 0.12 & 0.4 & 0.6 \\
\hline Sector Ontwikkeling en Beheer & 13.418 & 74 & 6 & 31 & 0.23 & 0.3 & 0.5 \\
\hline $\begin{array}{l}\text { Afdeling Inwonerszaken: } \\
\text { taakgroep Welzijn }\end{array}$ & 11.206 & 56 & 5 & $\begin{array}{r}12 \\
3\end{array}$ & $\begin{array}{r}0.11 \\
0.3\end{array}$ & 0.3 & 0.6 \\
\hline $\begin{array}{l}\text { Afdeling Maatschappij \& ruimte: } \\
\text { afdeling maatschappij }\end{array}$ & 9.838 & 78 & 8 & $\begin{array}{r}33 \\
9\end{array}$ & $\begin{array}{r}0.34 \\
0.9\end{array}$ & 0.3 & 0.3 \\
\hline $\begin{array}{r}\text { Gemiddelde } \\
\text { (range) }\end{array}$ & & & $\begin{array}{r}7.5 \\
(4-11)\end{array}$ & & $\begin{array}{r}0.55 \\
(0.12-1.8)\end{array}$ & $\begin{array}{r}0.38 \\
(0.2-0.8)\end{array}$ & $\begin{array}{r}0.51 \\
(0.3-0.6)\end{array}$ \\
\hline
\end{tabular}

gemeente, de beleidsafdeling waar VGZ is ondergebracht en de beschikbare formatie van de beleidsmedewerker voor VGZ en Wmo is er voor VGZ weinig tot bijna geen beleidscapacitei beschikbaar (zie Tabel 2). De beleidscompetenties contactvaardigheid op meerdere hiërarchische niveaus en kennis om VGZ te kunnen vertalen naar andere beleidsthema's bij de beleidsmedewerker VGZ wordt door acht van de dertien managers als noodzakelijk benoemd. Senioriteit van beleidsmedewerkers VGZ vinden vijf managers belangrijk: "Mensen die breder kunnen kijken en in staat zijn kritisch te zijn, verbindingen te leggen en andere collega's en lokale belanghebbenden te betrekken in de beleidsvorming." Evenzoveel managers geven aan dat intersectorale samenwerking met niet-VGZ beleidsterreinen wordt toegepast, zoals bijvoorbeeld "met ruimtelijk ordening in verband met luchtkwaliteit" of "bij het opstellen van een fietsenplan". Het vormgeven van integraal gezondheidsbeleid vraagt volgens drie managers wel meer VGZ beleidscapaciteit. In deze gemeenten is aanvullende beleidscapaciteit beschikbaar voor intersectoraal werken, doordat taken bijvoorbeeld verdeeld worden "onder een beleidsmedewerker VGZ en een programmamanager gezondheid" of door "het aannemen van een leefbaarheidscoördinator ter bevordering van intersectorale samenwerking".

\section{Aanwezige cultuur}

De genoemde items die betrekking hebben op de organisatiecultuur zijn de volgende: de samenwerking met de GGD verloopt uitsluitend via de beleidsmedewerker VGZ, er is een positief gemeentelijk klimaat voor intersectorale samenwerking, de manager heeft een visie op de samenwerking met de GGD, beleidsmedewerkers zitten fysiek bij elkaar, er is behoefte aan een cultuuromslag binnen de gemeente, een herziening van de interne gemeentelijke werkstructuur is reeds uitgevoerd (reorganisatie), de manager heeft uitvoerende beleidstaken, er is een herziening gaande van de interne gemeentelijke werkstructuur en er wordt gewerkt met een matrixstructuur (zie Tabel 1).

In alle gemeenten verloopt de samenwerking met de GGD via de beleidsmedewerker VGZ: "Ik kom nooit bij de GGD, enerzijds door het lokale gegeven van tijdgebrek en anderzijds om niet op de positie van de beleidsmedewerker VGZ te gaan zitten." Negen managers geven aan dat er binnen de eigen gemeente een positief gemeentelijk klimaat is voor intersectorale samenwerking: "Het heeft te maken met het feit dat we zelf vinden dat problemen in de gemeente integraal moeten worden opgepakt." Twee van deze managers zijn van mening dat het leggen van verbindingen "makkelijker gaat in een kleinere gemeente" (minder dan 20.000 inwoners), omdat "de lijnen binnen de organisatie wat korter zijn" en "de beslissingsbevoegdheid vaak hiërarchisch anders is geregeld". De helft van de afdelingsmanagers geeft aan niet afwijzend te staan tegenover meer samenwerking tussen GGD en gemeente op tactisch niveau, mits "de meerwaarde daarvan kan worden aangetoond" en "de GGD hiertoe het initiatief neemt". Het fysiek dicht bij elkaar zitten van beleidsmedewerkers wordt door zeven managers benoemd 
als factor die de interne samenwerking en beleidsvorming kan bevorderen. Vijf managers geven aan dat binnen de eigen gemeente een cultuuromslag nodig is om integraal beleid te kunnen realiseren: "Integraal beleid wordt hier door het bestuur en de politiek met de mond beleden. Maar in de praktijk komt daar in mijn beleving weinig van terecht." Binnen vier gemeenten is recentelijk de interne werkstructuur herzien. Drie managers geven aan zelf uitvoeren de beleidstaken te hebben: "Ik ben zelf meewerkend voorman, waardoor ik mijn tijd moet verdelen." In een gemeente is een interne reorganisatie gaande en in een andere gemeente wordt "met een matrixstructuur gewerkt".

\section{Manier van leiderschap}

Voor leiderschap zijn 3 items genoemd, namelijk of er sprake is van puur hiërarchisch leidinggeven (lijnmanagement), het beleidsproces inhoudelijk wordt aangestuurd (programmamanagement) en of de manager betrokken is bij het in 2006-2009 uitgevoerde GGD begeleidingstraject over integraal beleid overgewicht (zie Tabel 1).

Alle managers hanteren een hiërarchische stijl van leidinggeven en slechts drie geven aan ook inhoudelijk het beleidsproces te sturen: "Ik doe beide op verschillende niveaus. Ik hou me niet met de dagelijkse inhoud bezig, maar bijvoorbeeld wel met, wat de positie is van gezondheid en hoe kunnen we dat strategisch vertalen in beleidsprocessen?". Verder geven vijf van de ach managers van begeleidingsgemeenten aan zelf niet betrokken te zijn geweest bij het begeleidingstraject van de GGD: "Ik ben als manager er te weinig bij betrokken geweest. Voor mij was niet duidelijk wat er nu verwacht werd van onze organisatie."

\section{Rol GGD}

De volgende opmerkingen zijn gemaakt over de rol die de GGD Zuid Limburg kan vervullen ter bevordering van intersectorale samenwerking en integraal beleid. De GGD wordt door zeven managers VGZ gezien als een belangrijke regionale kennisorganisatie waarvan een gemeente gericht gebruik kan maken: "De GGD is een belangrijke kennisorganisatie voor het lokaal bestuur. We zijn collega's, alleen wordt dat niet altijd zo ervaren binnen een gemeente."Aangegeven wordt dat "in een kleine gemeente gezondheid minder aandacht en diepgang krijgt en dat er door deze gemeenten meer wordt geleund op de expertise van de GGD". Vier managers vragen expliciet aan de GGD om niet alleen data aan te leveren, maar tevens te komen met concrete voorbeelden hoe integraal beleid kan worden vormgegeven en welke doelstellingen er geformuleerd kunnen worden. Ook willen gemeenten graag meer informatie over gezondheidsthema's ontvangen. De GGD wordt verzocht duidelijker haar expertise aan gemeenten kenbaar te maken. Daarbij erkennen twee managers wel dat zij als manager uitsluitend via de lijn, dus de eigen beleidsmedewerker VGZ, worden gevoed over VGZ. Dit terwijl eigenlijk op "een hoger niveau een bredere integrale afweging gemaakt moet worden over of integraal gezond- heidsbeleid bevorderd moet worden én de wijze waarop". Terwijl persoonlijk contact wel voordelen heeft: "Zelf heb ik geen direct contact met de GGD, maar dat had ik in het verleden we toen onze bestuurder in het dagelijks bestuur van de GGD zat. Direct contact had zijn voordelen doordat zaken beter intern werden vertaald. Nu komt de informatie via de beleidsmedewerker waardoor de integraliteit wat moeilijker is te bewaken."

Drie managers zouden graag zien dat de GGD meer denkt vanuit lokale problemen en lokaal maatwerk levert. Twee managers geven hierbij aan dat de GGD als organisatie zelf ook een cultuuromslag nodig heeft. Integraal werken vraagt van de GGD een andere manier van werken. Dit vraagt om een andere insteek dan puur het uitvoeren van Wpg-taken en hiervoor moet de GGD zelf ook meer kennis en kunde ontwikkelen. Sommigen vinden dat de GGD de taak heeft om intersectorale samenwerking te stimuleren, terwijl anderen aangeven dat intersectorale samenwerking vooral door gemeenten zelf vormgegeven moet worden. Het proces van intersectoraal samenwerken kan volgens deze managers niet van buitenaf gestuurd worden, omdat de gemeente een regiefunctie heeft op het vlak van gezondheidsbeleid. Maar de gemeente zou de GGD wel kunnen uitdagen tot meer verdieping en verbinding: "Organiseer een keer per jaar een conferentie rondom een bepaald thema en betrek daar ook de GGD bij. Samen met het maatschappelijke veld de discussie aangaan hoe je elkaar beter van dienst kunt zijn." Eén manager spreekt expliciet het belang uit van een regionaal managersoverleg om gezamenlijk maatschappelijke ontwikkelingen in relatie tot de VGZ te bespreken: "Centrumgemeenten zijn vaak trekkende gemeenten. Deze gemeenten kunnen in nauwe samenwerking met de GGD veel voorwerk realiseren waarvan regionaal geprofiteerd kan worden."

\section{Ontwikkelmogelijkheden integraal gezondheidsbeleid}

Negen managers vinden het belangrijk dat er meer concrete, zichtbare en financieel haalbare koppelingen met gezondheid gemaakt worden in beleidsplannen. "Werken vanuit losse thema's heeft geen zin, want het moet gelinkt worden aan een programmabegroting. De programmabegroting geeft op hoofdlijnen aan waar we naartoe gaan en in de productbegroting wordt dat verder gedefinieerd." De invloed van gezondheid op andere beleidsterreinen dient duidelijker te worden benoemd en onderbouwd. "Het begint met het besef dat gezondheid een heel belangrijk thema is wat verweven zit in andere thema's. Dat moeten we zichtbaar en aantoonbaar maken dat het zin heeft om daarin te investeren." Het gemeentelijke MT heeft formeel de taak om gemeentelijke beleidsstukken te toetsen op onderlinge afstemming en verbinding, echter drie managers geven aan dat dit vaak te weinig gebeurt binnen een gemeente en dat integraliteit ook haar grenzen kent. "Door alles aan elkaar te verknopen krijg je ook niet de geëigende oplossingen." Het leggen van verbindingen tussen verschillende beleidsterreinen wordt gezien als een groeiproces. Het vereist een andere manier van denken en het maken van heldere afspraken over deze vorm van samenwerking is daarbij essentieel. Binnen gemeenten vindt 
waarschijnlijk al wel integraal gezondheidsbeleid plaats, maar dit beleid wordt volgens twee managers niet als zodanig herkend en benoemd omdat integraal beleid vaak een afgeleide doelstelling is. "Ik denk dat als we goed gaan kijken, dat er al veel meer gebeurt zonder dat het benoemd wordt als integraal gezondheidsbeleid. En als je het echt gaat labelen, dat mensen dan een 'aha erlebnis' krijgen. Dan laat je zien dat mensen het onbewust al doen, dit kan zorgen voor meer inhoudelijke verdieping in het eigen beleid."

\subsection{Discussie en conclusie}

\section{Samenwerking op operationeel niveau}

In dit onderzoek geven afdelingsmanagers VGZ aan dat verschillende factoren intersectorale samenwerking binnen een gemeente kunnen ondersteunen en bevorderen. Wat betreft managementsteun geeft het merendeel van de managers aan een positieve houding te hebben ten aanzien van integraal beleid, echter slechts de helft van de managers stimuleert actief intersectorale samenwerking binnen de eigen afdeling, ervaart bestuurlijk draagvlak en geeft aan dat integraal beleid is vertaald in gemeentelijke beleids- en begrotingsdocumenten Opmerkelijk is dat de intersectorale samenwerking met de GGD door het gemeentelijke management volledig gedelegeerd is naar het operationele niveau waar weinig en soms bijna geen beleidscapaciteit voor volksgezondheid aanwezig is. Zij voelen zich vooral hiërarchisch verantwoordelijk (lijnmanagement) voor volksgezondheid, de inhoudelijke betrokkenheid is in de praktijk zeer beperkt en gedelegeerd. Hier ligt wel een aangrijpingspunt voor verbetering. Zonder inhoudelijke kennis over volksgezondheid en het belang van een integrale aanpak is het moeilijk voor een lijnmanager om de beleidsmedewerker adequaat te faciliteren. Hierdoor is het vrijwel onmogelijk voor een beleidsmedewerker VGZ om intern binnen de eigen organisatie intersectoraal samen te werken en gezamenlijk met collega's integraal gezondheidsbeleid te formuleren.

\section{Verbetering beleidsondersteuning vanuit GGD}

Vanuit de Wpg kan een GGD haar gemeenten (on)gevraagd adviseren, echter in de praktijk gebeurt dit zelden en zijn gemeenten en GGD het vaak oneens of een raadsbesluit mogelijk effect heeft op de volksgezondheid(22). Voor de ontwikkeling van integraal gezondheidsbeleid is het echter belangrijk dat de GGD haar gemeenten proactief en intensief ondersteunt op operationeel en tactisch niveau in de beleidsvoorbereiding en -ontwikkeling. Managers geven aan behoefte te hebben aan concrete voorbeelden en praktische vertalingen van gezondheids thema's, die aansluiten bij actuele gemeentelijke maatschappelijke vraagstukken. Dit ter ondersteuning bij het intern bepleiten en aansturen van meer intersectorale samenwerking. De GGD wordt uitgenodigd om samen met gemeenten nieuwe beleidsadviserende initiatieven te ontplooien om gemeentelijke afdelingsmanagers VGZ doelgericht te betrekken bij beleidsoverstijgende gezondheidsthema's.

\section{Exploratief onderzoek}

Voor zover bekend is er nog weinig onderzoek gedaan naar de rol van het gemeentelijke management met betrekking tot intersectorale samenwerking en het formuleren van integraa gezondheidsbeleid. Het uitgevoerde kleinschalige kwalitatieve onderzoek is een eerste verkennende aanzet daartoe en kent duidelijk haar beperkingen. Zo is bijvoorbeeld niet nagevraagd bij portefeuillehouders of beleidsmedewerkers hoe deze professionals aankijken tegen de rol van het management bij het ontwikkelen van integraal gezondheidsbeleid. De onderhavige onderzoeksresultaten zijn gebaseerd op zelfrapportage en gaat uit van een beperkt aantal interviews binnen één specifieke regio van Nederland. Daarom is het moeilijk harde uitspraken te doen en is niet bekend in hoeverre de onderzoeksbevindingen generaliseerbaar zijn naar andere GGD-regio's in Nederland. Deze onderzoeksbevindingen zijn slechts een eerste indicatie over de (on)mogelijkheden van het gemeentelijke management om interne intersectorale samenwerking en de ontwikkeling van integraal gezondheidsbeleid te stimuleren.

\section{Aanbevelingen}

Om meer samenwerking tussen verschillende gemeentelijke beleidsterreinen, inclusief de GGD, te stimuleren is het in eerste instantie belangrijk dat op strategisch niveau bestuurders daadkrachtiger het belang van integrale gezondheidsdoelstellingen bepleiten, zorg dragen voor de formulering en besluitvorming van dit beleid én hiervoor voldoende middelen beschikbaar stellen $(16,23)$. Essentieel hierbij is helder te formuleren wat er moet gebeuren. Vervolgens sturen managers het proces aan over hoe men dit kan realiseren via interne en externe intersectorale samenwerking $(10,24)$. Een GGD heeft vanuit de wet de taak haar gemeenten (on)gevraagde te adviseren en te ondersteunen, echter in de praktijk gebeurt dit nog te weinig en zeker niet op tactisch niveau. Zonder gerichte inhoudelijke sturing op strategisch, tactisch en operationeel niveau is het moeilijk gezondheid structureel een plek te geven binnen de gemeentelijke organisatie. Managers dienen dit dynamische proces ambtelijk aan te sturen, intern te stimuleren en te faciliteren. De manager vervult een brugfunctie tussen bestuurder en beleidsmedewerker en dient te zorgen voor verticale aansturing en daarnaast ook voor het faciliteren van horizontale verbindingen met andere gemeentelijke beleidsterreinen en externe samenwerkingspartners. Als verlengd lokaal bestuur ligt hier een uitdaging voor de GGD om dit beleidsproces inhoudelijk te voeden. De GGD wordt aangeraden veel actiever op te treden in het (on)gevraagd adviseren van het gemeentelijke lijnmanagement. De zeer beperkte beschikbare beleidscapaciteit binnen gemeenten voor gezondheid versterkt de noodzaak tot gerichte beleidsondersteuning vanuit de GGD. De effecten van gezondheidsbeleid op andere gemeentelijke beleidsterreinen, zoals bijvoorbeeld de Wmo of het jeugdbeleid dienen door de GGD proactiever te worden uitgedragen. Daarnaast dient de GGD de invloed van andere beleidsterreinen op gezondheid duidelijker te benoemen. Echter dit vraagt om competentieverbetering van de GGD-professional, hetgeen noodzakelijk is om te kunnen uitgroeien tot kennisautoriteit op het 
vlak van integraal gezondheidsbeleid en om een serieuze gesprekpartner te kunnen zijn voor managers van gemeenten. lets wat nu kennelijk nog onvoldoende het geval is.

\subsection{Literatuur}

1. Baecke JAH, Derickx CL. Toekomstvisie op publieke gezondheid. Maatschappelijke vraagstukken centraal - verbinden verschillende beleidsdomeinen. Den Haag: VNG, 2009.

2. van Herten L, van Reeuwijk J, Pernis M, Koornstra A. Hoe zet je facetbeleid rond gezondheid op? De beterende hand / instrumenten voor de openbare gezondheidszorg. G2004;1:26-7.

3. Aarts M-J, Jeurissen MPJ, van Oers H, Schuit AJ, van de Goor IAM. Multi-sector policy action to create activity-friendly environments for children: A multiple-case study. Health Policy2010;in press.

4. Storm I, Verweij A, van der Lucht F. Integraal gezondheidsbeleid op lokaal niveau. Wat weten we en hoe nu verder? Bilthoven: RIVM, 2011 Contract No.: 270161004

5. Storm I, Zoest F, Broeder L. Integraal gezondheidsbeleid: theorie en toepassing. Bilthoven RIVM, 2007

6. Jackson SF, Perkins F, Khandor E, Cordwell L, Hamann S, Buasai S. Integrated health promotion strategies: a contribution to tackling current and future health challenges. Health Promotion International, 2007;21(S1):75-83.

7. Pagliccia N, Spiegel J, Alegret M, Bonet M, Martinez B, Yassi A. Network analysis as a too to assess the intersectoral management of health determinants at the local level: A report from an exploratory study of two Cuban municipalities. Social Science \& Medicine, 2010;71:394-9.

8. Jansen M. Mind the gap: Collaboration between practice, policy and research in local public health. Maastricht: University Maastricht; 2007.

9. Steenbakkers $M$, Jansen $M$, Maarse $H$, de Vries $N$. Lokaal integraal gezondheidsbeleid: intersectorale samenwerking vanuit het perspectief van gemeenten. Tijdschrift voor gezondheidswetenschappen, 2010;88(3):136-43.

10. Derksen W, Schaap L. Lokaal bestuur. 5e druk ed: Elsevier; 2007.

11. de Leeuw E, McNess A, Stagnitti K, Crisp B. It's research, Jim, but not as we know it. Acting at the Nexus. Integration of Research, Policy and Practice. Geelong: Deakin University, 2007.

12. St-Pierre L. Governance tools and Framework for Health in All Policies. Québec: National Collaborating centre for Healthy Public Policy. European Observatory on Health Systems and Policies. 2010.

13. Hoogerwerf A. Beleid, processen en effecten. In: Hoogerwerf A, Herweijer M, editors
Overheidsbeleid Een inleiding in de beleidswetenschap. Alphen aan de Rijn: Samson; 1998. p. 17-36.

14. de Leeuw E, Polman L. Health policy making: The Dutch experience. Social Science \& Medicine, 1995;40(3):331-8.

15. Bovens $M$, 't Hart P, Van Twist M, Rosenthal U. Sturing en beleid in het openbaar bestuur. Utrecht, 2007.

16. Maarse JAM. Sturing op gezondheidsdoeleinden en gezondheidswinst op macroniveau Achtergrondstudie bij RVZ-rapport: Sturen op gezondheid. In: RVZ, editor. 2011.

17. Mintzberg H. Organisatiestructuren. 2nd ed. Amsterdam: Pearson Education Benelux bv; 2008.

18. von Knorring M, de Rijk A, Alexanderson K. Managers' perceptions of the manager role in relation to physicians: a qualitative interview study of the top managers in Swedish health care. Health Services Research, 2010;10:271-83.

19. Fafard P. Evidence and Healthy Public Policy: Insights from Health and Political Sciences. Ottawa: National Collaborating Centre for Healthy Public Policy, 2008 May 2008.

20. Fleuren M, Wiefferink K, Paulussen T. Determinants of innovation within health care organizations: literature review and Delphi study. Int J Qual Health Care, 2004 Apr;16(2):107-23.

21. Steckler A, Goodman RM, Kegler MC. Mobilizing organizations for health enchancement. In: Glanz K, Rimer BK, Lewis FM, editors. Health behavior and health education Theory, research and practice. 3 ed ed. San Francisco: Jossey-Bass; 2002. p. 335-60.

22. Inspectie voor de Gezondheidszorg. Concept resultaten thematisch toezicht integraal beleid. 2008.

23. Rütten A, Röger U, Abu-Omar K, Frahsa A. Assessment of organizational readiness for health promotion policy implementation: test of a theoretical model. Health Promotion International, 2009;24(3):243-51.

24. Mannheimer LN, Lehto J, östlin P. Window of oppertunity for intersectoral health policy in Sweden-open, half-open or half-shut? Health Promotion International, 2007:22(4):307-15. 


\section{Hoofdstuk 5}

Lokaal integraal gezondheidsbeleid: effecten van beleidsondersteuning op de ontwikkeling van gemeentelijke intersectorale samenwerking
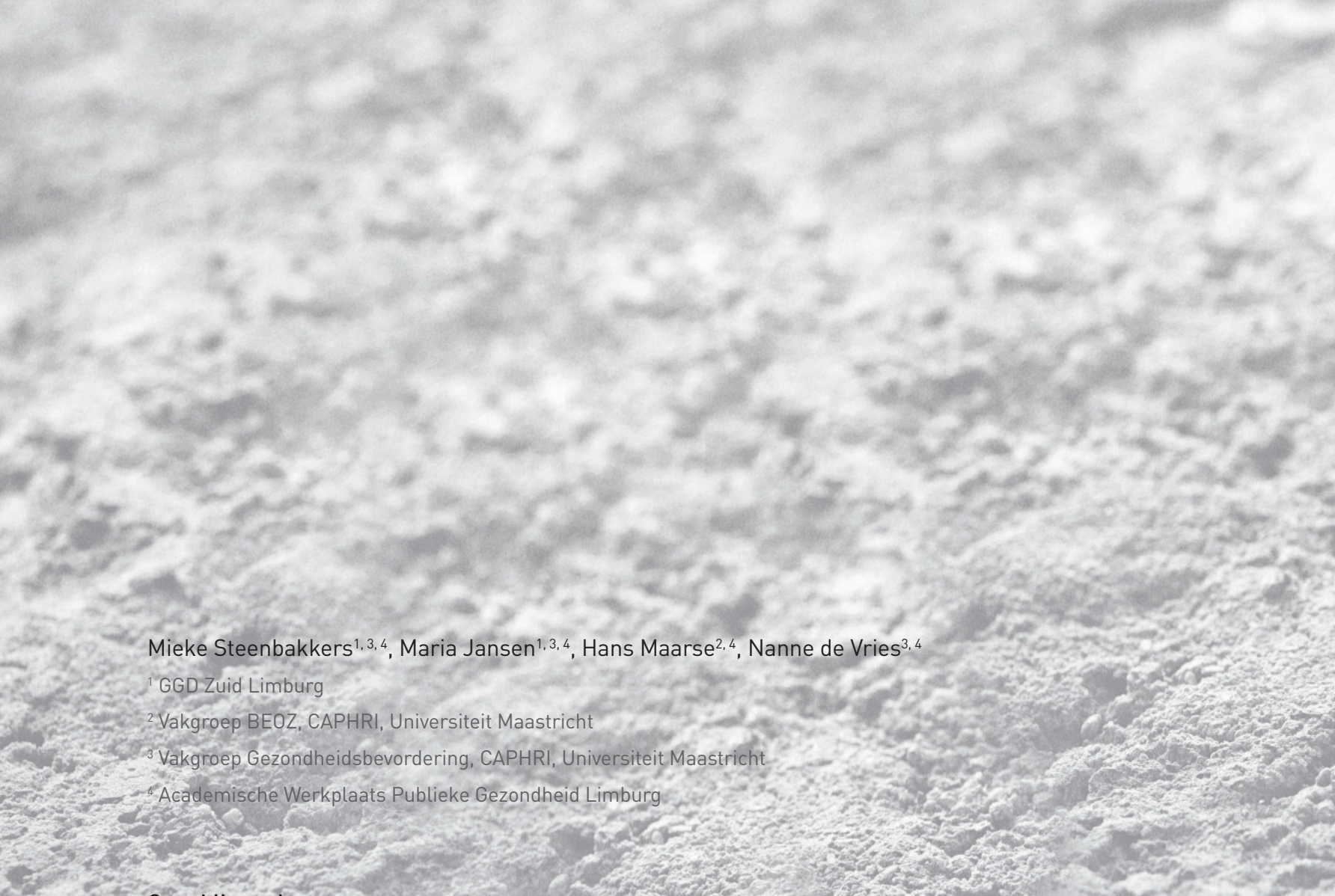

20.72ubliceerd:

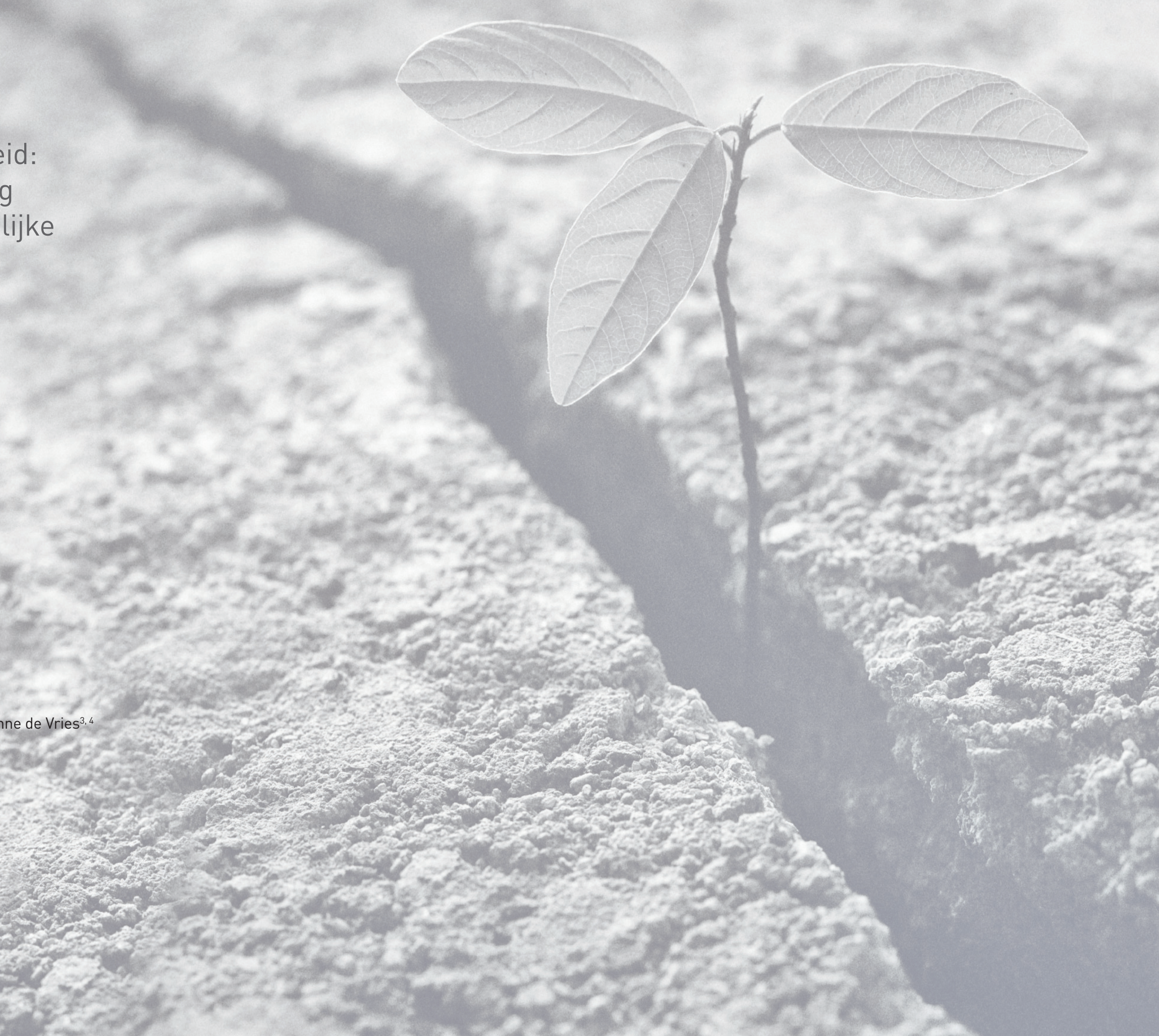




\section{Samenvatting}

Het belang van lokaal integraal gezondheidsbeleid wordt landelijk steeds vaker benadrukt Intersectorale samenwerking wordt gezien als een voorwaardenscheppend proces om te komen tot formulering van integraal beleid. Echter, lokaal worden nog weinig initiatieven ondernomen tot intersectorale samenwerking. Via een begeleidingstraject zijn gemeenten, zowel bestuurlijk als ambtelijk, ondersteund bij het bevorderen van de interne dialoog tussen gemeentelijke beleidsafdelingen. Voorafgaand en na afloop van dit begeleidingstraject is bij Limburgse gemeenten onderzocht hoe gemeenten aankijken tegen intersectorale samenwerking en het ontwikkelen van integraal gezondheidsbeleid. Portefeuillehouders, afdelingshoofden en beleidsmedewerkers zijn via een digitale vragenlijst hierover bevraagd.

Dit onderzoek laat zien dat de effecten van het begeleidingstraject in het algemeen zeer beperkt zijn, zowel in positieve als negatieve zin. Het begeleidingstraject heeft positief bijgedragen aan de vormgeving van integraal beleid voor het gezondheidsprobleem overgewicht. Met name de betrokken beleidsmedewerkers volksgezondheid zijn positief beïnvloed door het traject; hun kennis en kunde is toegenomen maar ook het besef dat het realiseren van intersectorale samenwerking binnen een gemeentelijke organisatie geen gemakkelijk proces is. Zeker als binnen de eigen gemeente bestuurders en managers niet of beperkt betrokken zijn.

Geconcludeerd wordt dat het stimuleren van intersectorale samenwerking rondom gezondheidsproblemen betrokkenheid en inzet vereist vanuit alle hiërarchische niveaus binnen een gemeente. Ook dient er meer overleg plaats te vinden met niet-VGZ beleidsterreinen. Met daadkrachtige sturing op managementniveau door een beleidsentrepeneur vanuit de gemeente en inbreng van kennis en kunde door een gezondheidsmakelaar vanuit de GGD, kan integraal beleid wellicht succesvoller dan tot nu toe worden vormgegeven.
5.1 Inleiding

Integraal gezondheidsbeleid (Health in All Policies, HiAP) wordt (inter)nationaal steeds vaker genoemd als een strategie ter verbetering van de volksgezondheid (1-5). Zorgen over de toe komstige ontwikkeling van de volksgezondheid resulteren in een groeiende politieke belangstelling voor deze strategie in Nederland en Europa (6). Complexe gezondheidsproblemen zoals bijvoorbeeld overgewicht vragen om een integrale aanpak. Een aanpak waarbij sectoren binnen en buiten het volksgezondheidsdomein samenwerken om gezondheidsschade te voorkómen en/of gezondheid te bevorderen (7-9). Intersectorale samenwerking is nodig om integraal gezondheidsbeleid te bevorderen $(10,11)$

In enkele landen (Finland, Noorwegen, Zweden, Engeland, Canada en Nieuw Zeeland) is al ervaring opgedaan met bestuurlijke instrumenten om intersectorale samenwerking te bevorderen $(9,12)$. Dit zijn instrumenten die zich richten op het veranderen van organisatiestructuren, beleids processen, het regelen van financiën en mandaat. Qua organisatiestructuren is er bijvoorbeeld gewerkt met kabinetscommissies om een belangrijke succesfactor als politiek commitment te verhogen. Ook zijn interdepartementale commissies en stuurgroepen ingesteld om loverkoepelende) beleidsplannen uit te werken. Soms wordt er gewerkt met netwerkstructuren die wisselend zijn van samenstelling en mogelijkheden tot instellingsoverstijgende coördinatie bieden. Of er worden aparte afdelingen ingesteld. Daarnaast kunnen processen beïnvloed worden door bijvoorbeeld het formuleren van gemeenschappelijke doelen en gezamenlijke evaluaties om onderlinge overeenstemming te realiseren. Subsidie of financiële steun voor gezamenlijke activiteiten kunnen het proces stimuleren. Voor het regelen van mandaat zijn wetten en regels krachtige instrumenten die ingezet kunnen worden om veranderingen te bewerkstelligen. Ook overeenstemmingprotocollen kunnen worden ingezet en hierbij is het essentieel om doelen, rollen en verantwoordelijkheden expliciet uit te schrijven. Bij het vastleggen van verantwoordelijkheden is het belangrijk om de voortrekker (instantie/persoon) te benoemen. Al deze instrumenten zijn hoofdzakelijk bedoeld om samenwerkingsmogelijkheden voor samenhangend beleid te creëren. De focus ligt op het realiseren van permanente verbanden voor discussies over gezondheidsproblemen binnen andere beleidsterreinen. Dit vraagt om een flinke investering, maar dit is nodig om een stabiel en lange termijn commitment voor integraal gezondheidsbeleid te creëren. Het faciliteren van dialogen tussen verschillenden beleidsterreinen is een belangrijk onderdeel van het beleidsproces (13).

Ook Nederlandse adviesraden hebben recentelijk geconcludeerd dat nationale en lokale overheden via intersectorale samenwerking veel gezondheidswinst kunnen realiseren (9). Echter, lokaal worden nog weinig initiatieven ondernomen. Lokale beleidsmakers ervaren verschillende barrières om integraal gezondheidsbeleid te ontwikkelen $(8,14)$. De Zuid-Limburgse gemeen- 
ten hebben in hun regionale prioriteitennota 2007-2011 aangegeven het belangrijk te vinden dat het gezondheidsprobleem overgewicht integraal wordt aangepakt(15). Gebaseerd op deze signalen is de GGD Zuid Limburg in samenwerking met het NIGZ gestart met een driejarig begeleidingstraject om intersectorale samenwerking te stimuleren en integraal gezondheidsbeleid te ontwikkelen en specifiek voor het gezondheidsprobleem overgewicht $(16,17)$. De focus lag op het beïnvloeden van interne processen binnen de gemeentelijke organisatie. Zuid-Limburgse gemeenten konden zich aanmelden voor deelname aan het begeleidingstraject. Negen gemeenten hebben dit daadwerkelijk gedaan. Deze gemeenten zijn, zowel bestuurlijk als ambtelijk, ondersteund bij het bevorderen van de interne dialoog tussen het gemeentelijke beleidsterrein volksgezondheid (VGZ) en andere gemeentelijke beleidsterreinen (niet-VGZ). De begeleiding was vooral gericht op het versterken van de competenties van de gemeentelijke beleidsmedewerkers volksgezondheid. Dit gebeurde door lokaal te werken in een trio Igemeentelijke beleidsmedewerker volksgezondheid, gezondheidsbevorderaar GGD en medewerker NIGZ) en regionale intervisiebijeenkomsten te houden met deze trio's. Portefeuillehouders volksgezondheid (gemeentelijke bestuurders) zijn via regionale bijeenkomsten geïnformeerd. Betrokkenheid van gemeentelijke afdelingshoofden volksgezondheid verliep via de beleidsmedewerker of portefeuillehouder volksgezondheid. Vanuit de Academische Werkplaats Publieke Gezondheid Limburg (18) is onderzoek uitgevoerd naar de vraag of dit begeleidingstraject bijdraagt aan de ontwikkeling van lokaal integraal gezondheidsbeleid. Hiertoe is voorafgaand en na afloop van het begeleidingstraject bij Limburgse gemeenten onderzocht hoe gemeenten aankijken tegen intersectorale samenwerking en het ontwikkelen van integraal gezondheids beleid. Dit artikel presenteert de effecten van het begeleidingstraject.

\subsection{Methode van onderzoek}

\section{Onderzoekspopulatie/interviews}

$\mathrm{Er}$ is een quasi-experimenteel onderzoek uitgevoerd. Negen van de 19 Zuid-Limburgse gemeenten hebben zich als experimentele gemeente aangemeld voor deelname aan het begeleidingstraject. Zeventien Noord- en Zuid-Limburgse gemeenten fungeerde als controle gemeenten. Voorafgaand aan de start van het begeleidingstraject (2007) en na afloop (2009) is in de 9 experimentele en 17 controle gemeenten een digitale vragenlijst afgenomen. Deze vragenlijst is afgenomen bij portefeuillehouders, afdelingsmanagers en beleidsmedewerkers verspreid over zes verschillende gemeentelijke beleidsterreinen. De namen en e-mailadressen zijn door de beleidsmedewerkers volksgezondheid aangeleverd zowel voor de voor- als de nameting (19)

\section{Digitale vragenlijs}

De vragenlijst is gebaseerd op een conceptueel model over samenwerking tussen beleidsterreinen (20-22). Elk beleidsterrein wordt vertikaal (hiërarchisch) aangestuurd. Om intersectorale samenwerking te realiseren moeten beleidsterreinen ook horizontaal samenwerken. Zo moeten portefeuillehouders (strategisch niveau), afdelingshoofden/afdelingsmanagers (tactisch niveau) en beleidsmedewerkers (operationeel niveau) van verschillende beleidsterreinen met elkaar in overleg. Of dit lukt hangt per niveau van verschillende samenwerkingsdeterminanten a (zie Figuur 1). Voor een uitgebreidere beschrijving van deze determinanten wordt verwezen naar eerdere publicaties $(19,21)$. De verschillende determinanten zijn verwerkt in een digitale vragenlijst en direct bevraagd (ja/nee) of indirect via stellingen met de antwoordcategorie eens/oneens (23). Op strategisch niveau is gevraagd naar de politieke prioriteit van integraal gezondheidsbeleid binnen een gemeente (7 stellingen), gemeentelijk draagvlak/leiderschap (3 stellingen) en

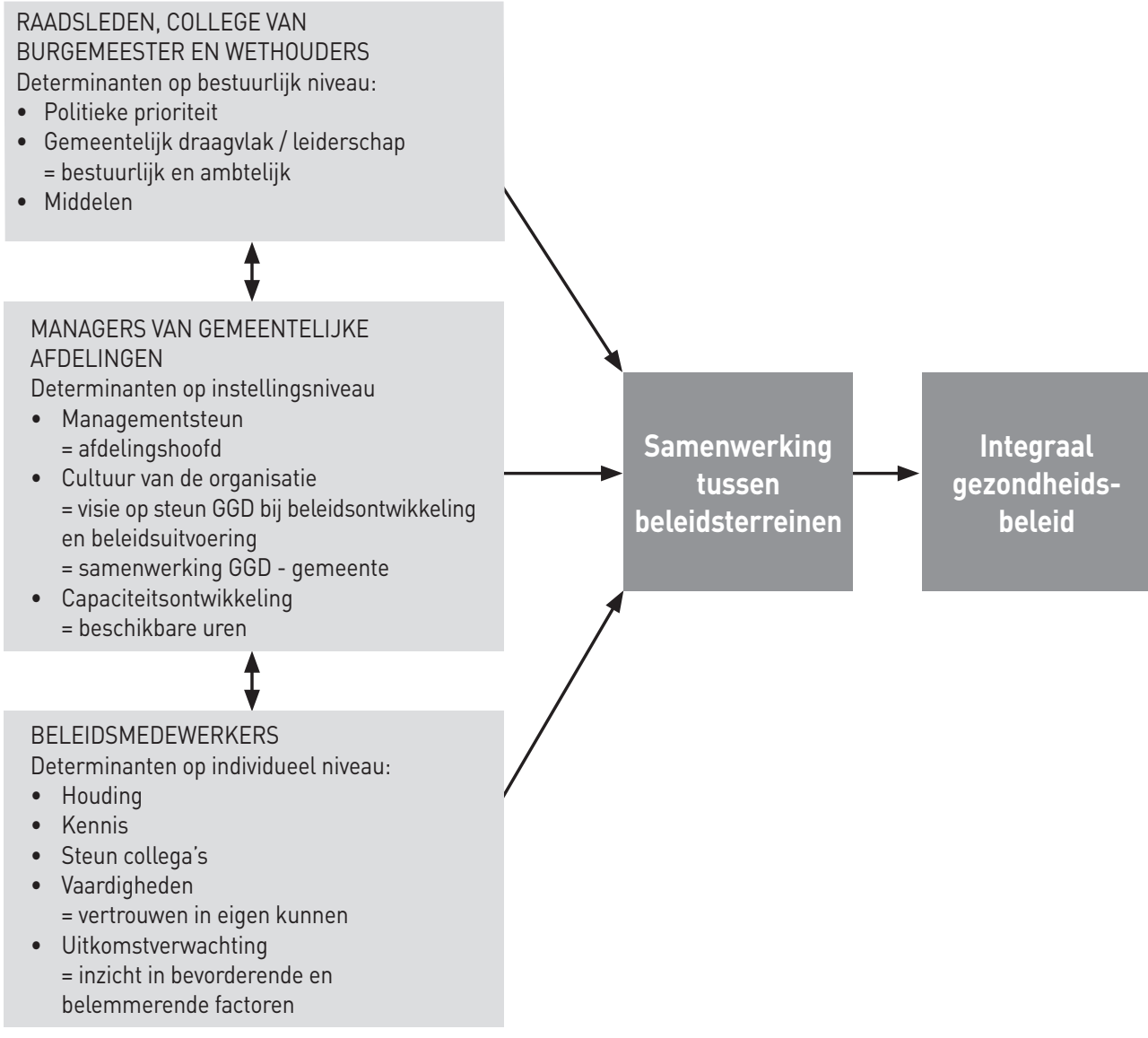

Figuur 1: Samenwerkingsdeterminanten gemeten bij gemeentelijke actoren (portefeuillehouders, afdelingshoofden en 
het beschikbaar stellen van middelen (menskracht/geld). Op tactisch niveau zijn de determinanten steun van het afdelingshoofd (2 stellingen), het aantal beschikbare uren voor volksgezondheid en welzijn en de cultuur van de organisatie (7 stellingen) bevraagd. En op operationeel niveau is onder beleidsmedewerkers VGZ expliciet gevraagd naar kennis over (2 stellingen), houding ( 4 stellingen), steun collega's en vertrouwen in eigen kunnen (4 stellingen) met betrekking tot integraal gezondheidsbeleid. Onder VGZ respondenten is gevraagd welke belemmerende en bevorderende factoren zij ervaren en welke uitkomstverwachting zij hebben van integraal gezondheidsbeleid (19 stellingen). Of en hoe integraal beleid voor overgewicht tot stand komt is onderzocht door te vragen naar de gemeentelijke prioriteit overgewicht (3 stellingen) en naar aandacht voor het thema overgewicht binnen gemeentelijke overlegstructuren (3 stellingen). Om te achterhalen in hoeverre gemeenten rondom het gezondheidsprobleem overgewicht intersectoraal samenwerken is bij alle beleidsmedewerkers gevraagd naar de (geplande) toepassing van een twaalftal integrale interventies.

Analyses

Negatief geformuleerde vragen zijn gehercodeerd, zodat voor alle vragen een hogere score als positief kan worden beschouwd. Voor de betreffende stellingen die tezamen een samenwerkingsdeterminant conceptualiseren zijn Cronbach's alpha (a) en schaalgemiddelden berekend. Om te kunnen bepalen of het begeleidingstraject effect heeft gehad, zijn de schaalgemiddelden voor de gemeten samenwerkingsdeterminanten op de voor- en nameting van elkaar afgetrokken en met behulp van een variantie-analyse getoetst op significante verschillen (zie Tabel 1 en 2):

- in de somscore van de schaalgemiddelden ten opzichte van nul (geen verandering),

- tussen functionarissen in gemeenten die wel of niet begeleid zijn bij het ontwikkelen van integraal gezondheidsbeleid (wel vs geen begeleiding),

- tussen functionarissen die wel of niet werkzaam zijn binnen het beleidsterrein volksgezondheid en welzijn (VGZ vs niet-VGZ).

Tussentijdse wisselingen van baan kunnen invloed hebben op de beschikbare competenties bij respondenten, zoals kennis over en vertrouwen in eigen kunnen om integraal te werken Daarom zijn de variantie-analyses twee keer uitgevoerd. Eén keer per individu waarbij dezelfde persoon heeft deelgenomen aan de voor- en nameting. De tweede keer is rekening gehouden met een tussentijdse wisseling van baan gedurende de onderzoeksperiode door een respondent, waarbij diens antwoord met dat van de opvolger wordt vergeleken. Omdat de beide analyses vergelijkbare resultaten laten zien, worden alleen de resultaten van de analyse met dezelfde personen besproken. Een beperkt aantal samenwerkingsdeterminanten of deelvragen zoals beschikbare middelen, steun collega's en uren, met antwoordcategorieën ja/nee, zijn met Chi-square $\left(\mathrm{x}^{2}\right)$ getoetst op significante verschillen.

\subsection{Resultaten}

\section{Beschrijving respondenten}

Aan de voor- en nameting hebben respectievelijk 226 en 206 respondenten deelgenomen met een gemiddelde respons van 70 en $67.1 \%$ (19). Voor 143 respondenten was het mogelijk de gegevens van de voor- met de nameting te vergelijken op basis van functie. Door tussentijdse wisselingen van baan gedurende de onderzoeksperiode $(\mathrm{N}=24)$ is de voor- en nameting 119 keer door dezelfde respondenten ingevuld. Door het exploratieve karakter van dit onderzoek is ervoor gekozen om de resultaten van alle gemeten determinanten kort te bespreken, ook als verschillen niet statistisch significant zijn.

\section{Vergelijking voor- en nameting}

Op strategisch niveau is de somscore van de politieke prioriteit voor integraal gezondheidsbeleid significant afgenomen (zie Tabel 1). Het gemeentelijk draagvlak is iets toegenomen maar dit is niet significant. In vergelijking met de voormeting zijn de beschikbare middelen voor de ontwikkeling van gezondheidsbeleid in begeleidingsgemeenten afgenomen, zegt 33.3 vs $27.6 \%$ van de respondenten. Op tactische niveau is de ervaren steun van het afdelingshoofd volksgezondheid voor integraal werken significant afgenomen. Het gemiddelde aantal uren beschikbaar voor beleidsmedewerkers volksgezondheid is toegenomen na afloop van het begeleidingstraject in alle gemeenten, maar vooral in begeleidingsgemeenten (11.4 vs 16.5 uur per week). Op operationeel niveau hebben respondenten een positievere houding gekregen, maar de kennis over integraal gezondheidsbeleid is niet veranderd. Het vertrouwen in eigen kunnen bij beleidsmedewerkers volksgezondheid is afgenomen. In vergelijking met de voormeting geven deze beleidsmedewerkers bijvoorbeeld minder vaak aan (37.3 vs $29.6 \%$ ) dat integraal beleid onderdeel is van hun beleidsnotities. Respondenten werkzaam voor het beleidsterrein volksgezondheid kunnen na afloop van het begeleidingstraject meer factoren benoemen die integraal beleid bevorderen dan ervoor.

\section{Verschillen naar deelname aan begeleidingstraject}

Bij begeleidingsgemeenten is de politieke prioriteit voor integraal werken significant afgenomen terwijl deze bij gemeenten zonder begeleiding is toegenomen (zie Tabel 1). Het gemeentelijk draagvlak voor integraal gezondheidsbeleid is alleen binnen gemeenten die geen begeleiding hebben ontvangen iets toegenomen. Ongeacht deelname aan het begeleidingstraject zijn alle beleidsmedewerkers volksgezondheid minder positief geworden over de ervaren steun van het afdelingshoofd. Over de samenwerking tussen de GGD en gemeente zijn met name begeleidingsgemeenten positiever geworden. In de nameting vinden respondenten in begeleidingsgemeente bijvoorbeeld vaker dan respondenten in niet-begeleidingsgemeenten dat de GGD ingezet kan worden in de beleidsontwikkeling (59.2\% vs $58.5 \%$ ) en de beleidsuitvoering ( 59.2 vs $56.2 \%$ ). 

Tabel 1: Variantie-analyse vergelijking voor- en nameting van samenwerkingsdeterminanten integraal gezondheidsbeleid

\begin{tabular}{|c|c|c|c|c|c|c|c|c|c|c|}
\hline & \multicolumn{2}{|c|}{$\begin{array}{l}\text { Voor - na } \\
\text { meting } \\
\text { N }\end{array}$} & \multicolumn{2}{|c|}{ Begeleiding } & \multicolumn{2}{|c|}{$\begin{array}{l}\text { Geen } \\
\text { begeleiding } \\
\mathrm{N}\end{array}$} & \multicolumn{2}{|c|}{$\begin{array}{l}\text { VGZ } \\
\mathrm{N}\end{array}$} & \multicolumn{2}{|c|}{$\begin{array}{l}\text { Niet VGZ } \\
\text { N }\end{array}$} \\
\hline \multicolumn{11}{|c|}{ Strategische samenwerkingsdeterminanten } \\
\hline $\begin{array}{l}\text { Politieke prioriteit } \\
\text { (gemid.score; range: 0-7) }\end{array}$ & 119 & $-0.08^{*}$ & 42 & $-0.45^{a}$ & 77 & $0.12^{\mathrm{b}}$ & 45 & -0.44 & 74 & -0.11 \\
\hline $\begin{array}{l}\text { Gemeentelijk } \\
\text { draagvlak/leiderschap } \\
\text { (gemid.score; range: } 0-3 \text { ) }\end{array}$ & 119 & 0.15 & 42 & 0.00 & 77 & 0.23 & 45 & 0.00 & 74 & 0.24 \\
\hline \multicolumn{11}{|c|}{ Tactische samenwerkingsdeterminanten } \\
\hline $\begin{array}{l}\text { Steun afdelingshoofd } \\
\text { Alleen beleidsmedewerker VGZ } \\
\text { (gemid.score; range: } 0-2 \text { ) }\end{array}$ & 14 & $-0.29 *$ & 3 & -0.66 & 11 & -0.18 & & & & \\
\hline $\begin{array}{l}\text { Samenwerking GGD - gemeente } \\
\text { Alleen respondenten die contact } \\
\text { hebben met GGD } \\
\text { (gemid.score range: } 0-7 \text { ) }\end{array}$ & 57 & -0.23 & 23 & 0.09 & 34 & -0.44 & 33 & -0.24 & 24 & -0.21 \\
\hline \multicolumn{11}{|c|}{ Operationele samenwerkingsdeterminanten } \\
\hline $\begin{array}{l}\text { Houding } \\
\text { (gemid.score; range: } 0-4 \text { ) }\end{array}$ & 119 & 0.27 & 42 & 0.24 & 77 & 0.29 & 45 & 0.29 & 74 & 0.26 \\
\hline $\begin{array}{l}\text { Kennis } \\
\text { (gemid.score; range: 0-2) }\end{array}$ & 119 & -0.03 & 42 & 0.10 & 77 & -0.10 & 45 & 1.11 & 74 & -0.12 \\
\hline $\begin{array}{l}\text { Vertrouwen in eigen kunnen } \\
\text { Alleen beleidsmedewerker VGZ } \\
\text { (gemid.score; range: } 0-4 \text { ) }\end{array}$ & 14 & -0.14 & 3 & 0.67 & 11 & -0.36 & & & & \\
\hline $\begin{array}{l}\text { Bevorderende en } \\
\text { belemmerende factoren } \\
\text { Alleen respondenten VGZ } \\
\text { (gemid.score; range: } 0-19 \text { ) }\end{array}$ & 17 & 0.77 & 10 & 1.60 & 7 & -0.42 & & & & \\
\hline
\end{tabular}

* gemiddelden die significant afwijken van nul $=p<.05$

significante verschillen tussen gemiddelden binnen een kolom $=p<.0$

Qua competenties is de kennis en het vertrouwen in eigen kunnen bij beleidsmedewerkers volksgezondheid in begeleidingsgemeenten toegenomen. In gemeenten zonder begeleiding is deze afgenomen. Dit vertrouwen komt tot uiting in het zelf uitleggen van integraal werken met concrete voorbeelden en het zelf mobiliseren van collega's van andere beleidsterreinen. En in de nameting ervaren beleidsmedewerkers volksgezondheid in begeleidingsgemeenten bijvoorbeeld meer steun van directe collega's voor integraal werken dan in niet-begeleidingsgemeenten (69.9 vs $50.0 \%$ ). In begeleidingsgemeenten benoemen VGZ respondenten meer bevorderende factoren, terwijl in gemeenten zonder begeleiding meer belemmeringen worden ervaren.

\section{Verschillen naar beleidsterrein}

De politieke prioriteit voor integraal gezondheidsbeleid is afgenomen, deze afname is het sterkst binnen het beleidsterrein volksgezondheid (VGZ) (zie Tabel 1). Het gemeentelijke draagvlak voor integraal beleid is uitsluitend toegenomen bij niet-VGZ respondenten is. De samenwerking tussen GGD en gemeenten wordt door zowel VGZ als niet-VGZ respondenten die contact hebben met de GGD als minder positief beoordeeld. VGZ en niet-VGZ respondenten hebben een positievere houding gekregen met betrekking tot integraal gezondheidsbeleid. De kennis over integraal gezondheidsbeleid is toegenomen bij VGZ respondenten en afgenomen bij niet-VGZ respondenten (zie Tabel 1).

\section{Casus: integraal gezondheidsbeleid naar overgewich}

De prioriteit voor overgewicht is toegenomen binnen gemeenten, vooral bij niet-begeleidingsgemeenten en onder VGZ respondenten (zie Tabel 2). Ongeacht deelname aan het begeleidingstraject komt de aanpak van overgewicht vaker aan de orde binnen gemeentelijke overlegstructuren, deze toename is het sterkst bij niet-VGZ respondenten. Het toepassen van interventies voor overgewicht is significant toegenomen, terwijl het van plan zijn interventies gericht op over-

Tabel 2: Variantie-analyse vergelijking voor- en nameting van samenwerkingsdeterminanten integraal gezondheidsbeleid I $N=119$ dezelfde respondenten

\begin{tabular}{|c|c|c|c|c|c|c|c|c|c|c|}
\hline & $\begin{array}{l}\text { Voor } \\
\text { nam } \\
\mathrm{N}\end{array}$ & & $\mathrm{Be}$ & iding & $\begin{array}{l}\text { Gee } \\
\text { beg } \\
\mathrm{N}\end{array}$ & ding & $\begin{array}{l}\text { VGZ } \\
\text { N }\end{array}$ & & Nie & \\
\hline Integraal gezondheidsbele & ergew & & & & & & & & & \\
\hline $\begin{array}{l}\text { Gemeentelijke prioriteit } \\
\text { overgewicht } \\
\text { (gemid.score; range: 0-3) }\end{array}$ & 119 & 0.32 & 42 & 0.19 & 77 & 0.38 & 45 & 0.38 & 74 & 0.27 \\
\hline $\begin{array}{l}\text { Overgewicht in gemeentelij } \\
\text { overleg } \\
\text { (gemid.score; range: 0-3) }\end{array}$ & 119 & 0.14 & 42 & 0.12 & 77 & 0.16 & 45 & 0.17 & 74 & 0.91 \\
\hline Interventies overgewicht $t$ & eigeı & emeent & & & & & & & & \\
\hline $\begin{array}{l}\text { Interventies overgewicht } \\
\text { toegepast } \\
\text { Alleen beleidsmedewerkers } \\
\text { VGZ en niet VGZ } \\
\text { (gemid.score; range: 0-12) }\end{array}$ & 31 & $1.10^{*}$ & 11 & 1.81 & 20 & 0.70 & 9 & 0.22 & 22 & 1.45 \\
\hline $\begin{array}{l}\text { Interventies overgewicht } \\
\text { van plan } \\
\text { Alleen beleidsmedewerkers } \\
\text { VGZ en niet VGZ } \\
\text { (gemid.score; range: 0-12) }\end{array}$ & 31 & $-0.52^{*}$ & 11 & -0.36 & 20 & -0.60 & 9 & -0.67 & 22 & -0.45 \\
\hline
\end{tabular}


gewicht te gaan toepassen significant is afgenomen. Het aantal niet-VGZ respondenten dat aangeeft dat het eigen beleidsterrein geen raakvlakken heeft met het gezondheidsprobleem overgewich is toegenomen in de nameting ( 25.7 vs $30.8 \%$ ). De waardering voor zowel de interne ( 4.88 vs 5.19) als externe ( 5.24 vs 5.38 ) samenwerking binnen de gemeentelijke organisatie rondom het gezondheidsprobleem overgewicht is toegenomen gedurende het begeleidings-traject.

\subsection{Discussie en conclusie}

\section{Geen sterke eenduidige effecten}

Op basis van dit onderzoek kan geconcludeerd worden dat de effecten van het uitgevoerde begeleidingstraject om gemeenten te ondersteunen bij het ontwikkelen van integraal beleid zeer beperkt zijn, zowel in positieve als negatieve zin. Vooral op strategisch en tactisch niveau is het commitment voor integraal gezondheidsbeleid afgenomen. Geconcretiseerd voor het gezondheidsprobleem overgewicht blijken de effecten iets eenduidiger, sterker en positiever te zijn. Overgewicht heeft intern binnen de organisatie meer prioriteit gekregen, het thema word vaker besproken in ambtelijke overleggen en interventies worden significant vaker toegepast. Dit positieve effect kan waarschijnlijk verklaard worden uit de inhoudelijke focus van de begeleiding, met accent op overgewicht (17).

Het begeleidingstraject heeft niet geleid tot het gebruik van bepaalde bestuurlijke instrumenten die intersectorale samenwerking kunnen bevorderen, zoals een wijziging in de organisatiestructuur, het beleidsproces, mandatering of financiële prikkels. Er zijn wel meer uren beschikbaar gesteld voor volksgezondheid. Het is niet helder geworden wie binnen de gemeentelijke organisatie verantwoordelijk is voor intersectorale samenwerking en de ontwikkeling van integraal gezondheidsbeleid. Gemeenten die hebben deelgenomen aan het begeleidingstraject hadden bij de voormeting een betere uitgangspositie om intersectoraal samen te werken op strategisch, tactisch en operationeel niveau en leken beter in staat om vanuit volksgezondheid een brug te slaan naar andere beleidsterreinen (19).

Echter, op basis van deze onderzoeksresultaten kan geconcludeerd worden dat deze betere uitgangspositie niet heeft geleid tot meer intersectorale samenwerking en integraal beleid op alle organisatieniveaus binnen een gemeente. Met name het operationele niveau is positief beïnvloed door het begeleidingstraject.

Voor de beperkte effecten van de verstrekte beleidsondersteuning op de ontwikkeling van gemeentelijke intersectorale samenwerking en integraal beleid zijn verschillende verklaringen te geven. Allereerst kan er sprake zijn van regressie naar het gemiddelde tussen de voor- en nameting. Bij herhaling van een meting is namelijk de statistische kans groter dat de resultaten dichter bij het gemiddelde komen te liggen dan dat ze verder afwijken van het gemiddelde.

Een tweede mogelijke verklaring kan zijn dat de opzet en uitwerking van het begeleidingstraject onvoldoende krachtig is geweest om daadwerkelijk het interne gemeentelijke beleidsproces te kunnen beïnvloeden. Het begeleidingstraject was met name gericht op het bevorderen van de dialoog tussen verschillende gemeentelijke beleidsterreinen. Vooral de beleidsmedewerker volksgezondheid (operationeel niveau) is de interne dialoog met andere beleidssectoren aangegaan en op zoek gegaan naar nieuwe intersectorale beleidsafstemming. Bestuurders (strategisch niveau) hebben zich op hoofdlijnen beziggehouden met het begeleidingstraject en afdelingsmanagers (tactische niveau) zijn niet of nauwelijks betrokken geweest $(19,24)$. Het is moeilijk om zonder voldoende betrokkenheid en mandaat vanuit het strategische en tactische niveau daadwerkelijk veranderingen te realiseren in organisatiestructuren en beleidsprocessen $(4,12,25)$. Het accent lag op het ondersteunen van de eerste fasen van het beleidsproces; van beleidsvoorbereiding naar beleidsbepaling (17). De literatuur geeft aan dat het ontwikkelen van integraal gezondheidsbeleid een gecompliceerd proces is dat nadrukkelijk aangestuurd en gecoördineerd dient te worden $(4,26)$. Sturing van processen wordt bevorderd door het formuleren van heldere en gemeenschappelijke gezondheidsdoelen en door aan te geven via welke aanpak deze doelen bereikt kunnen worden $(12,27,28)$. Echter, het aantal bewezen effectieve integrale interventies is nog steeds beperkt waardoor het de begeleiders ontbrak aan overtuigingskracht om voor de ene of de andere aanpak te pleiten. Dit resulteerde in onvoldoende sturing op zowe bestuurlijk als op managementniveau tijdens het begeleidingstraject, waardoor het moeilijk was vanuit verschillende beleidsterreinen en hiërarchische niveaus inzet en betrokkenheid te verkrijgen. De randvoorwaarden voor samenwerking waren onvoldoende aanwezig en wijzigingen in het beleidsproces werden vrijwel niet gerealiseerd. Het begeleidingstraject heeft slechts in één begeleidingsgemeente geleid tot een kleine verandering in het beleidsproces. In deze gemeente is de mogelijkheid gecreëerd om de beleidsmedewerker volksgezondheid aan een intern multidisciplinair overleg te laten deelnemen waardoor het volksgezondheidsperspectief wordt meegenomen in de ontwerpfase van bestemmingsplannen (17).

Een derde verklaring kan zijn gelegen in de ambtelijke discontinuïteit binnen het beleidsterrein volksgezondheid. Centrale actoren binnen het begeleidingstraject waren de beleidsmedewerker, gevolgd door de portefeuillehouder en in mindere mate het afdelingshoofd van het beleidsterrein volksgezondheid. De beleidsmedewerker volksgezondheid is geschoold in het belang van integraal werken, het stimuleren van een sectoroverstijgende interne dialoog ten behoeve van integraal beleid en had intensief contact met de GGD. Echter, gedurende het begeleidingstraject zijn zes van de negen beleidsmedewerkers van functie gewisseld, evenals een afdelingsmanager en twee portefeuillehouders volksgezondheid. Deze beleidsmedewerkers vinden vaker dat 
de GGD ingezet kan worden bij de beleidsontwikkeling en -uitvoering van integraal gezondheidsbeleid. Voor deze gemeenten is de GGD een continue ondersteuningsfactor geweest gedurende het begeleidingstraject, terwijl er bij gemeenten en specifiek de afdeling volksgezondheid vele functiewisselingen zijn geweest.

Ten vierde kunnen hoge verwachtingen bij de start van het begeleidingstraject, vooral bij portefeuillehouders en beleidsmedewerkers die een betere uitgangspositie hadden (19), makkelijk omslaan in teleurstellingen. Zo is binnen begeleidingsgemeenten de politieke prioriteit voor integraal gezondheidbeleid afgenomen. Beleidsmedewerkers volksgezondheid binnen begeleidingsgemeenten geven aan dat - ondanks het feit dat men meer vertrouwen heeft in het eigen kunnen - hun kennis is toegenomen, men meer bevorderende factoren waarneemt en zij minder steun van het eigen afdelingsmanager ervaren voor het ontwikkelen van integraal beleid. De afdelingsmanager volksgezondheid was niet direct betrokken in het begeleidingstraject en diende via de beleidsmedewerker en portefeuillehouder volksgezondheid te worden geïnformeerd over het belang van integraal werken. Echter, een beleidsmedewerker kan zonder steun van het tactische niveau geen veranderingen realiseren in organisatieprocessen en -structuren (21). De beleidsmedewerkers hebben zelf ervaren hoe moeilijk het is om vanuit operationee niveau intersectorale samenwerking te stimuleren. Beleidsmedewerkers volksgezondheid binnen begeleidingsgemeenten zijn wellicht mede daardoor terughoudender over integraal werken gaan denken.

\section{Beperkingen van het onderzoek}

Het blijkt lastig te zijn om de effectiviteit van integraal gezondheidsbeleid wetenschappelijk te onderzoeken en aan te tonen (29). Voor zover bekend is (inter)nationaal nog weinig onderzoek gedaan bij gemeentelijke actoren naar integraal gezondheidsbeleid. Er bestaan geen gevalideerde vragenlijsten voor het meten van sectoroverstijgende samenwerking voor integraal beleid. De door ons ontwikkelde vragenlijst bevat de belangrijkste belemmerende en bevorderende factoren voor intersectorale samenwerking waardoor we een redelijk volledig beeld hebben kunnen schetsen. Belangrijke kanttekening is wel dat de vragenlijst uitgaat van zelfgerapporteerde bevindingen van de respondenten, waardoor het risico op sociale wenselijke antwoorden nooit volledig is uit te sluiten. Verder was per gemeente de bereidheid van de beleidsmedewerker VGZ om mailadressen aan te leveren doorslaggevend voor deelname aan het onderzoek. Besluitvorming tot deelname aan het begeleidingstraject gebeurde op vrijwillige basis, waardoor mogelijk met name gemeenten die al een positieve houding hebben ten aanzien van integraal gezondheidsbeleid zich voor dit begeleidingstraject hebben aangemeld (selectiebias). Deze betere uitgangspositie binnen begeleidingsgemeenten kan de onderzoeksresultaten hebben beïnvloed Zo kunnen verbeteringen bovenop de al gunstige startpositie misschien moeilijker te realiseren zijn, waardoor een positief effect nauwelijks zichtbaar wordt of pakt de begeleiding ongunstig uit omdat men beseft hoe moeilijk integraal beleid te realiseren is, waardoor een negatief effect ontstaat. Ook tussentijdse wisselingen van functies kunnen de uitkomsten van dit onderzoek negatief beïnvloed hebben, omdat hiermee veel opgebouwde kennis en vaardigheden verloren gaat en er geen effecten van het begeleidingstraject gemeten kunnen worden.

\section{Aanbevelingen}

Op basis van de resultaten van dit onderzoek bevelen wij aan om de verantwoordelijkheden van de verschillende betrokken gemeentelijke actoren, en met name die van de afdelingsmanagers, ten aanzien van het stimuleren van intersectorale samenwerking explicieter te benoemen, om te voorkomen dat niemand zich aangesproken voelt als probleemeigenaar $(30,31)$. Van oudsher is binnen gemeenten gezondheidsbeleid geen dominant 'policy frame'. Alleen bij actuele bedreigingen van de sociale veiligheid, zoals bijvoorbeeld bij een chemische brand of Q-koorts, krijgt gezondheid politieke aandacht. Veel niet-VGZ beleidsmakers, afdelingsmanagers en portefeuillehouders zijn zich niet bewust van de invloed van hun eigen beleid op bepaalde gezondheids problemen. Daarom dient het belang van intersectoraal werken aan gezondheidsproblemen explicieter te worden uitgelegd aan gemeenten (32). Essentieel in dit kader is om te erkennen dat gezondheid niet een primair doel hoeft te zijn, maar een middel om andere meer overkoepelende gemeentelijke doelen te realiseren, zoals bijvoorbeeld het bevorderen van de sociale veiligheid, sociale cohesie, arbeidsparticipatie en leefbaarheid.

In dit kader bevelen wij een zeker opportunisme aan, het benutten van kansen tot samenwerking en verbinding waar deze zich voordoen. Met een vooraf vastgestelde doelstelling, bijvoorbeeld dat tien procent meer schoolkinderen met de fiets of te voet naar school gaat, maakt het vervolgens niet uit langs welk beleidsterrein deze doelstelling wordt gehaald. Als de sector ruimtelijke ordening kansen biedt, wordt het doel langs die weg gerealiseerd, maar het kan evengoed via het sportbeleid, jeugdbeleid of het verkeersveiligheidsbeleid. Zo'n werkwijze wordt ook wel omgeschreven in termen van een 'window of opportunity' $(33,34)$. Hiervoor zijn beleidsentrepreneurs nodig die de kansen zien en initiatief nemen. Beleidsentrepreneurs kunnen vanuit een gemeente of een $\operatorname{GGD}(35,36)$ strategisch en tactisch acteren tussen verschillende beleidsterreinen, ze kunnen de samenwerking initiëren en aanmoedigen, met name bij niet-VGZ beleidsterreinen. Daarnaast kunnen gezondheidsmakelaars vanuit een GGD worden ingezet. Gezondheidsmakelaars zijn inhoudelijk geschoold in het bij elkaar brengen van vraag en aanbod, daar waar het gezondheid betreft. In enkele Nederlandse gemeenten zijn sinds kort dergelijke gezondheidsmakelaars aangesteld. De positionering van een gezondheidsmakelaar of beleidsentrepreneur binnen een organisatie (uitvoerend, beleidsmatig, managementniveau of bestuurlijk) bepaalt mede de mate van macht, mandaat en middelen die deze functionaris ter beschikking heeft. Voldoende doorzettingsmacht is essentieel en daarom adviseren wij voor de beleidsentrepreneur een positie op managementniveau. 
Uit de (inter)nationale literatuur blijkt dat interdepartementale commissies samenwerking kunnen stimuleren $(9,12)$. Wellicht is het raadzaam om binnen gemeenten de afdelingsmanagers als beleidsentrepreneurs in te zetten en opdracht te geven intersectorale commissies te formeren rondom een bepaald probleemgebied. De gezondheidsmakelaar kan op operationeel niveau inhoudelijk aan de slag met het door de beleidsentrepreneur in gang gezette initiatief.

Vanwege de grote ambtelijke discontinuïteit binnen gemeenten bevelen wij gemeenten tevens aan frequenter GGD-professionals te betrekken bij het interne beleidsproces. Het door ons ontwikkelde begeleidingstraject was daar een eerste poging toe. De opzet en uitwerking bleek weliswaar onvoldoende krachtig om structurele veranderingen te realiseren maar biedt zeker kansen tot verbetering. De magere resultaten tot dusver zijn dan ook wellicht niet zozeer het gevolg van onwil van de niet-VGZ beleidsterreinen, maar eerder van onmacht en onkunde van het VGZ-beleidsterrein en de GGD.

GGD'en worden daarom aangeraden stevig te investeren in competentiebevordering van hun gezondheidsbevorderaars, zowel inhoudelijk als in de procesbegeleiding, zodat ze ook volwaardig als gezondheidsmakelaar ingezet kunnen worden binnen het gemeentelijke beleidsproces. Inhoudelijk gaat het dan om kennis over evidence-based en practice-based interventies buiten het domein van de volksgezondheid, bijvoorbeeld welke gezondheidswinst is haalbaar door intensivering van het fietsbeleid, hoe verhouden kosten en baten zich en, als deze kennis ontbreekt, welk type onderzoek is mogelijk om kosten en baten in de tijd te meten? Academische werkplaatsen kunnen een bijdrage leveren aan dergelijk onderzoek. Daarnaast is scholing nodig om het gemeentelijke proces daadkrachtiger te kunnen ondersteunen. Samenwerken is een competentie en vraagt om een open, nieuwsgierige, enthousiasmerende en stimulerende houding. GGD professionals zouden getraind kunnen worden in hoe ze het proces met niet-VGZ beleidsmedewerkers kunnen aangaan. Gezien de beperkingen van het door ons uitgevoerde onderzoek is meer onderzoek gewenst. Aangeraden wordt om vanuit de academische werkplaatsen veldexperimenten uit te voeren of integrale uitvoeringsplannen in de tijd nauwkeurig te volgen om zowel het proces als de effecten transparant te maken, zodat we ervan kunnen leren.

In allerlei nationale documenten wordt integraal werken vermeld als veelbelovend en aanbevelenswaardig $(5,6,37-39)$. Gemeentelijke gezondheidsnota's voor de beleidsperiode 2007-2011 vermelden vaak het belang van een integrale aanpak van overgewicht (15), maar dit wil niet zeggen dat dit onderwerp tot nu toe binnen de gemeentelijke organisatie een hoge beleidsprioriteit heeft gekregen. Waar op landelijk niveau vanuit het ministerie de vormgeving van integraal lokaal gezondheidsbeleid bijna als een vanzelfsprekendheid wordt voorgesteld, blijkt de concrete uitwerking ervan op lokaal niveau een bijzonder lastige opgave te zijn, waar veel gemeenten mee worstelen (38).

\subsection{Literatuur}

1. WHO. Ottawa charter for health promotion. Health Promotion International 1986;1:iii-v.

2. WHO. Health Equity in All Urban Policies. A report on the expert consultation on Intersectoral Action (ISA) in the prevention of Noncommunicable conditions. Kobe, Japan: World Health Organization 2009 22-24 june.

3. Kickbusch I, McCann W, Sherbon T. Adelaide revisited: from healthy public policy to Health in All Policies. Health Promotion International 2008;23(1):Editorial.

4. Kickbusch I. Policy Innovation for Health. New York: Springer Science + Business Media; 2009.

5. Ministerie van Volksgezondheid Welzijn en Sport. Gezond gedrag bevorderd. Eindrapportage van de werkgroep IBO. Interdepartementaal beleidsonderzoek, 2006-2007, nr.1. Den Haag 2007.

6. van der Lucht F, Polder J. Van gezond naar beter. Kernrapport Volksgezondheid Toekomst Verkenning 2010 [Dutch Public Health Status and Forecasts Report 2010]. Bilthoven: Rijksinstituut voor Volksgezondheid en Milieu 2010

7. Verweij A, den Broeder JM. Integraal gezondheidsbeleid samengevat [Integrated Health Policy summarized]. Bilthoven, : RIVM; 2006 [cited www.nationaalkompas.nl > preventie> thema's>integraal gezondheidsbeleid 13 maart 2006].

8. Storm I, Zoest F, Broeder L. Integraal gezondheidsbeleid: theorie en toepassing. Bilthoven RIVM 2007.

9. RVZ, Onderwijsraad, Rob. Buiten de gebaande paden. Advies over intersectoraal gezondheidsbeleid, advies uitgebracht door de Raad voor de Volksgezondheid en Zorg, de Onderwijs raad en de Raad voor het openbaar bestuur. Zoetermeer 2009

10. Jackson SF, Perkins F, Khandor E, Cordwell L, Hamann S, Buasai S. Integrated health promotion strategies: a contribution to tackling current and future health challenges. Health Promotion International 2007;21(S1):75-83.

11. Pagliccia N, Spiegel J, Alegret M, Bonet M, Martinez B, Yassi A. Network analysis as a tool to assess the intersectoral management of health determinants at the local level: A report from an exploratory study of two Cuban municipalities. Social Science \& Medicine 2010;71:394-9.

12. St-Pierre L. Governance tools and Framework for Health in All Policies. Québec: National Collaborating centre for Healthy Public Policy. European Observatory on Health Systems and Policies. 2010.

13. Fafard P. Evidence and Healthy Public Policy: Insights from Health and Political Sciences. Ottawa: National Collaborating Centre for Healthy Public Policy2008 May 2008.

14. Schuit J, Storm I. Successen en valkuilen van integraal gezondheidsbeleid. Tijdschrift voor gezondheidswetenschappen 2007;85(8):415-6. 
15. Zuid Limburgse gemeenten. Samen gezond! Regionale prioriteiten Volksgezondheidsbeleid Zuid Limburg 2007-2011. Maastricht 2007.

16. Ruland E, Fransen G, Dorgelo A. Drie jaar werken aan gezondheidsbevordering op lokaal niveau. Activiteiten en resultaten van het programma Lokaal Gezond. Woerden: NIGZ 2009

17. Steenbakkers M, Jansen M, Hesdahl B, ten Dam J, Maarse H. Gemeentelijke intersectorale samenwerking stimuleren: Lokale begeleiding bij het ontwikkelen van integraal gezondheidsbeleid. Tijdschrift voor gezondheidswetenschappen 2011;5:266-73.

18. GGD Zuid Limburg, Universiteit Maastricht. Academische Werkplaats Publieke Gezondheid Limburg (AW). Maastricht2006.

19. Steenbakkers M, Jansen M, Maarse H, de Vries N. Lokaal integraal gezondheidsbeleid: intersectorale samenwerking vanuit het perspectief van gemeenten. Tijdschrift voor gezondheidswetenschappen 2010;88(3):136-43.

20. Bekker M. The Politics of Healthy Policies: Redesigning Health Impact Assessment to Integrate Health in Public Policy. Rotterdam: Erasmus University Rotterdam; 2007.

21. Jansen M. Mind the gap: Collaboration between practice, policy and research in local public health. Maastricht: University Maastricht; 2007.

22. Jansen M, de Vries N, Kok G, van Oers HA. Collaboration between pratice, policy and research in local public health in the Netherlands. Health Policy 2008;86:295-307.

23. Steenbakkers M. www.academischewerkplaatslimburg.nl. 2007.

24. Steenbakkers M, Jansen M, Maarse H, De Vries N. Sturing op integraal gezondheidsbeleid: de rol van het gemeentelijke management. Tijdschrift voor gezondheidswetenschappen 2011; Accepted.

25. Warner M, Gould N. Integrating health in all policies at the local level: using network governance to create 'Virtual Reorganization by Design'. In: Kickbusch I, editor. Policy Innovation for Health. New York: Springer; 2009. p. 125-63.

26. Hunter DJ. Leading for health and Wellbeing: the need for a new paradigm. Journal of Public Health 2009;31(2):202-4

27. de Leeuw E, McNess A, Stagnitti K, Crisp B. It's research, Jim, but not as we know it Acting at the Nexus. Integration of Research, Policy and Practice. Geelong: Deakin University 2007.

28. Maarse JAM. Sturing op gezondheidsdoeleinden en gezondheidswinst op macroniveau Achtergrondstudie bij RVZ-rapport: Sturen op gezondheid. In: RVZ, editor. 2011.

29. Barr V, Pedersen S, Pennock M, Rootman I. Health equity through intersectoral action: an analysis of 18 country case studies. WHO: Public Health afency of Canada 2008.

30. Hoeijmakers M. Local health policy development processes. Health promotion and network perspectives on local health policy-making in the Netherlands. Maastricht: University Maastricht; 2005.
31. Ruland $\mathrm{E}$. Bestuurlijke verankering van innovaties in de openbare gezondheidszorg: lessen uit de casus Hartslag Limburg. Maastricht: Universiteit Maastricht; 2008.

32. Aarts M-J, Jeurissen MPJ, van Oers H, Schuit AJ, van de Goor IAM. Multi-sector policy action to create activity-friendly environments for children: A multiple-case study. Health Policy 2011;101:11-19.

33. Kingdon JW. Agendas, alternatives and public policies. New York: Addison-Wesley Educational Publishers Inc.; 2003.

34. Mannheimer LN, Lehto J, östlin P. Window of opportunity for intersectoral health policy in Sweden-open, half-open or half-shut? Health Promotion International2007;22(4):307-15.

35. Hoeijmakers M, de Leeuw E, Kenis PN, de Vries NK. Lokaal gezondheidsbeleid: een beleidsentrepreneur voor integraal beleid. Tijdschrift voor gezondheidswetenschappen 2007;85(1):43-6.

36. Harting J, Kunst AE, Kwan A, Stronks K. A 'health broker' role as a catalyst of change to promote health: an experiment in deprived Dutch neighbourhoods. Health Promotion International Advance Access 2010(November 10):1-17.

37. Inspectie voor de Gezondheidszorg. Staat van de gezondheidszorg 2005, deelrapport. De gemeenten zijn veel meer betrokken bij de openbare gezondheidszorg, ze moeten nu meer zelf uitvoeren. Resultaten van het toezicht op de gemeentelijke betrokkenheid 2004. Den Haag: IGZ 2005.

38. Inspectie, Gezondheidszorg vd. Staat van de Gezondheidszorg 2010. Meer effect mogelijk van publieke gezondheidszorg. Utrecht: IGZ 2010.

39. CGL. Handreiking Gezonde Gemeente. www.loketgezondleven.nl; 2010. Ottawa: National Collaborating Centre for Healthy Public Policy, 2008 May 2008. 


\section{Abstract}

The Dutch government encourages municipalities to develop 'Health in All Policies' (HiAP). The development of such a policy requires inter-sectoral collaboration, however municipalities show little initiative in this regard. Operating in an advisory role, the regional Public Health Service (PHS) has supported municipalities in South-Limburg in setting up inter-sectoral collaboration. A coaching program for municipal stakeholders was developed and implemented to improve HiAP, using obesity as an example.

To determine the effectiveness of this coaching program, civil servants, managers and municipal executive (aldermen) were invited to fill in an Internet questionnaire prior to and at the completion of the program. By means of a log-book all activities were registered in coached municipalities and in-depth interviews were held with municipal managers. Outcomes were scored depending on the stage of HiAP proposals.

Six of the nine coached municipalities showed concrete outcomes in terms of HiAP proposals. The results show that more support and involvement at each system level stimulates the development of HiAP. The program contributed positively to the implementation of HiAP interventions targeting obesity. The pretest results for coached municipalities were better compared to noncoached municipalities. However, after 30 months of coaching this positive starting position faded away. We recommend that the municipal management become more involved in the development of HiAP and advise the PHS to increasingly demonstrate their expertise. Here lies a challenge for municipalities and their regional PHS.

\subsection{Introduction}

\section{Health in All Policies}

In the Netherlands, as in many countries worldwide, local governments are held responsible for local public health policy by national law and are obligated to work together with a Public Health Service (PHS, in Dutch GGD) (1). Municipalities have a central role in providing Public Health Services to improve health and to reduce socioeconomic health inequalities (2). Lower educated people in the Netherlands live 6 to 7 years less than those who are highly educated, and they live 14 years longer in poor health (3). This fact in combination with the high prevalence rates of chronic diseases, obesity and mental health problems implies the need for solutions outside the health domain, which has been cited as 'Health in All Policies' (HiAP) (4, 5). The complex policy challenges posed by obesity ( 40 to $50 \%$ of the Dutch adult population is obese (3), for instance, are a good example of the rationale underpinning the presumed need to work in policy networks to tackle this public health concern. Policy domains such as Spatial Planning \& Environment, Social Affairs, Traffic \& Transportation, Public Safety, Youth \& Education, Recreation \& Sports need to be involved (6). So far, there is limited knowledge about how to organize these partnerships at the local level nor the outcome: obesity prevention (7).

The Dutch government encourages municipalities to develop HiAP. The development of such a policy requires inter-sectoral collaboration, however municipalities show little initiative with regard to inter-sectoral collaboration (8, 9). There are very few mechanisms that stimulate local policymakers outside the health domain to consider health determinants and health impacts. Usually each policy domain works to its own logic and own performance indicators without regarding the impact certain measures may have on health of the population. The method of Health Impact Assessment (HIA) provides an opportunity to discuss the health impacts of measures taken by non-health domains but recent research has indicated that this tool is not very effective in the Netherlands. The current emphasis of HIA on a technocratic and rational decision making design obstructs rather than facilitates the integration of health in public policy $(10,11)$. The evidence-based reasoning in HIA appeared to be not effective, so far. These negative results encouraged the emergence of a coaching program based on the principles of knowledge sharing and dialogue and creating the necessary white space conditions for further progress (12). Municipal authorities have to define Public Health policy. In most policy plans since 2006 the importance of an integrated approach to, for instance, the obesity problem, is proposed (13). Operating in an advisory role the regional PHS South Limburg together with the National Institute on Health Promotion and Disease Prevention (NIHPDP) developed a coaching program for nine municipals in the region to collaboratively find ways to improve HiAP, using obesity as an example. 


\section{Conceptual framework}

The process from policy preparation to policy decisions is a hierarchical process, with municipal executive (aldermen) having the final say, managers or heads of departments in between and the civil servants at the bottom. Therefore, the coaching program distinguished between stakeholders at the strategic or administrative, tactical or managerial, and operational or executive level. A conceptual framework was developed based on theoretically essential determinants of inter-sectoral collaboration, marked in italics, to stimulate inter-sectoral collaboration within and between policy domains (14) (see Figure 1). The logic behind it is that the realization of HiAP requires agenda setting of a special health concern at the administrative level to give the issue political priority $(15,16)$. Administrative commitment and leadership are both essential elements to propel an issue onto the political agenda of different policy domains (17). When policy stakeholders at the administrative level consent to political priority setting, the policy preparation process can be initiated. The managers can facilitate or restrict civil servants in their activities at the executive level. They will have to facilitate the transition towards more collaboration between municipalities' policy domains including their regional PHS. The transition poses challenges with respect to organizational culture, managerial support and policy capacity $(18,19)$. Policy capacity relates to available human resources in terms of time, competence, and capability i.e. the ability to adapt to change, generate new knowledge, and continuously improve performance with colleagues in other policy domains (20). Having realized the preconditions for collaboration at the tactical level, the different executive professionals can initiate co-operation at the operational level. Knowledge, attitudes, perceived social and outcome expectations, and self-efficacy seem to be important personal determinants of both judging one's own policy frame of reference and of entering another policy domain (19).

This constitutes a system level approach in which collaboration is viewed as a function of individuals and of the environments in which individuals operate. The various levels are viewed as embedded systems (21). The conceptual framework illustrates the reciprocity between the stakeholders at each level within a municipality, i.e. municipal executive (aldermen), managers and civil servants. To create inter-sectoral collaboration the usual communication in a vertical, hierarchical direction needs to be supplemented with communication horizontally between the different policy domains at each system level (see Figure 1).

\section{Aim of the study}

This study seeks to structurally map and explore the effectiveness of a coaching program which was implemented by the regional PHS South Limburg and the NIHPDP. The aim of the study is to see if municipalities are able to make progress in inter-sectoral collaboration at the strategic, tactical and operational level and in the assessment of HiAP proposals. Findings from this study could help policy makers and PHS-professionals understand how to more effectively develop HiAP proposals.

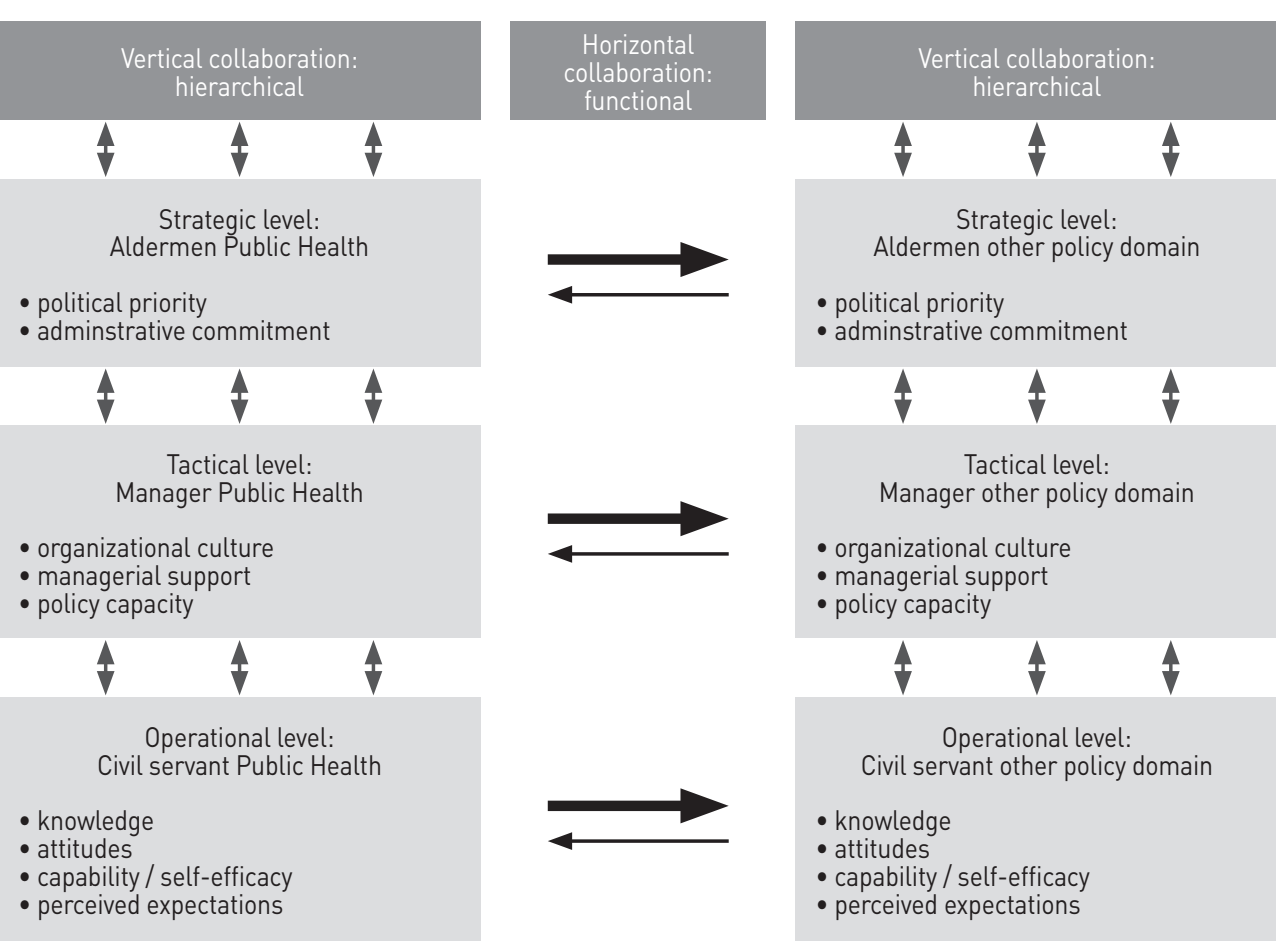

Figure 1: Vertical and horizontal collaboration within an municipal organization and collaboration determinants measured at three organizational levels (14).

\subsection{Methods}

The development of HiAP is not a discrete event but rather part of on ongoing process in which different policy domains at the three system levels work together. Therefore a participatory action research design was chosen in which intermediary results were given as feedback to the stakeholders for direct broader use. The effect of the program in terms of municipal intersectoral collaboration and developing HiAP is evaluated by a pre- and post-test measurement.

\section{The coaching program}

The coaching program aimed to enable municipal inter-sectoral collaboration, and to build HiAP proposals, by addressing stakeholders at the three different system levels. For these aspects the following data is collected: 


\section{- At the strategic level:}

Three regional conferences were held for municipal executive (aldermen) with a Public Health portfolio. The conferences addressed the need for agenda setting and advocacy, showing visible commitment and leadership, and creating resources. Political urgency of inter-sectoral collaboration on the issue of obesity was clarified, the coaching program was explained and halfway through the program intermediate results were presented (e.g. agreements in each municipality, successes and problems, steps to continue).

\section{- At tactical level:}

The managers were informed by the municipal executive (aldermen) and civil servants about the coaching program, the need for HiAP and organizational transition, in order to facilitate inter-sectoral collaboration. Managers had to agree to allow a minimal time expenditure of $2 \mathrm{~h}$ per week by the relevant Public Health civil servant.

\section{- At the operational level:}

- A master class for regional civil servants and PHS-professionals on stimulating intersectoral collaboration was held. The application of policy instruments e.g. HIA, screening determinants of policy domains, and the quick scan for HiAP (22) on obesity were discussed. For PHS-professionals, four successive sessions were held to attain adequate competency to advise their civil service counterparts.

- Active learning was stimulated by the formation of a trio of the Public Health civil servant from the municipality, the PHS-professional and the health promoter of the NIHPDP. The trios operated from May 2007 until November 2009 and were actively involved in organizing inter-sectoral collaboration during this time. Firstly, they described the local public health status and forecasts, the prevailing political and administrative powers, and the existing community projects. Next, they had a meeting with their municipal councilor to elaborate on eligible inter-sectoral collaboration that could tackle the obesity problem. Subsequently the trio worked through the policy preparation process by analyzing the obesity problem, and formulating attainable goals in term of integrated policy, desired results, an action plan, policy domains to collaborate with, and the time frame. In between they could meet the stakeholders at other levels, on their own initiative. In seven meetings experts trained skills and reflected on new experiments. It was envisaged that the trios would end up with HiAP plans that would be agreed on in local government and would therefore be ready for implementation.

\subsection{Research method}

\section{Data collection}

In total, 32 municipalities in the Netherlands region of Limburg were involved in this research, including 9 municipalities who decided on voluntary bases to participate in the coaching program to encourage integrated health policy regarding obesity (from now on called the coached ones'). Reasons not to join the coaching program were lack of time and no positive attitude to HiAP.

A mixed method design was used which consisted of an Internet questionnaire, logbook registries, and in-depth interviews. A pre- and post-test Internet questionnaire at the start (TO) and 30 months later (T1) was conducted to measure the impact of the coaching program. Nine coached municipalities were compared to 23 non-coached municipalities. Municipal executive (aldermen) (strategic level), managers (tactical level) and civil servants (operational level) of different policy sectors (Public Health \& Welfare, Sports \& Recreation, Youth \& Education, Traffic \& Transportation, Spatial Planning \& Environment and Social Affairs) were invited to fill in the questionnaire which measured the relevant determinants of inter-sectoral collaboration at each level as formulated in the conceptual framework (see figure 1). These determinants were indirectly measured by means of a number of propositions (see figure 1) with an answer category agree/not agree (23). The number of actual implemented interventions for obesity prevention were investigated as well as the intended interventions.

In the 9 municipalities all activities, contacts, time investment, resources, barriers that influenced the process, were registered by means of a log-book kept by civil servants, PHS-professionals and health promoters of the NIHPDP. In-depth interviews were held with thirteen Public Health municipal managers, including eight managers from coached municipalities, about their role in stimulating municipal inter-sectoral vertical and horizontal collaboration and the development of HiAP (24).

Outcomes were scored depending on the stage of HiAP proposals: score 0 when the coaching had stopped before final date, score 1 when no HiAP proposals had been developed, score 2 when it was in preparation, score 3 when the proposal was completed, score 4 when there was an administrative policy decision, and score 5 when the proposal was implemented (25).

\section{Data analysis}

For each cluster of propositions in the Internet questionnaire Cronbach's Alpha (a) and scale averages were calculated. Scale averages of the pre-test were subtracted from the post-test results (T1-TO). All statistical analyzes were performed by using ANOVA analyzes (SPSS version 15.0) to check significant differences in sum scores of scale averages to zero (no change in time) and between professionals from coached and non-coached municipalities. Policy capacity is calculated in average available hours per week. Response at T0 was $70 \%(\mathrm{~N}=226)$ and at $\mathrm{T}$ 
67.1\% ( $N=206)$. In total 119 respondents, municipal executive laldermen) ( $N=26)$, managers $(\mathrm{N}=35)$ and civil servants ( $\mathrm{N}=58$ ), filled in the questionnaire two times and these respondents are used in the analyzes. Not all respondents filled in all questions $(23,26)$.

Log-book data was categorized in 24 activities divided in strategic, tactical and operational ac tivities; e.g. to advocate HiAP by councilors, to discuss HiAP progress by manager, to participate in intervision meetings and write a HiAP proposal by civil servants. Each activity was given a score between 0 and 1 ; score 1 'realized', score 0.5 'partly realized' and score 0 'not realized'. Subtotal scores were counted at each system level with a maximum of 8 points at strategic, 7 at tactical, and 9 at operational level (25). To see if there was a relation between impact and activities of municipal stakeholders on the strategic, tactical and operational level during the coaching program, the log-book scores of the 9 coached municipalities were compared. The assumption was that a higher log-book score i.e. activities at all system levels, would facilitate the development of HiAP proposals.

All in-depth interviews with municipal managers of the Public Health domain were recorded The recordings were transcribed into key notes and the notes were then linked to the items in the conceptual framework. An independent researcher repeated the procedure: overall agreement was $87.1 \%(24)$

\subsection{Results}

\section{HiAP proposals}

Six of the nine municipalities where the coaching program was delivered showed concrete outcomes of HiAP proposals. Two municipalities withdrew from participation prematurely (score 0). One municipality could not achieve any policy result (score 1). In three municipalities the issue of health promotion was included in policy documents that were in preparation (score 2). One municipality included a health check for obesity in spatial planning and environment policy proposals that were completed and ready for decision (score 3). In one municipality a new policy procedure was accepted stating that the Public Health civil servant should participate in multi-sectoral consultations about environmental policy proposals. To support the civil servant with knowledge and skills, a manual was developed together with the regional PHS (score 4). Finally, one municipality purchased an existing evidenced-based HiAP intervention for people in debt (27) which could be implemented immediately (score 5). Within coached municipalities the log-book score was positively associated with the outcome score: the higher the log-book score the higher the outcome score in terms of HiAP proposals (see Graphic 1). With regard to actual number of implemented interventions for obesity prevention, there was a significant increase in coached municipalities compared to the non-coached ones but the intention to implement new interventions in the future had decreased. Furthermore, there was a little, but not significant increase in political priority and frequency of consultation (see Table 1).

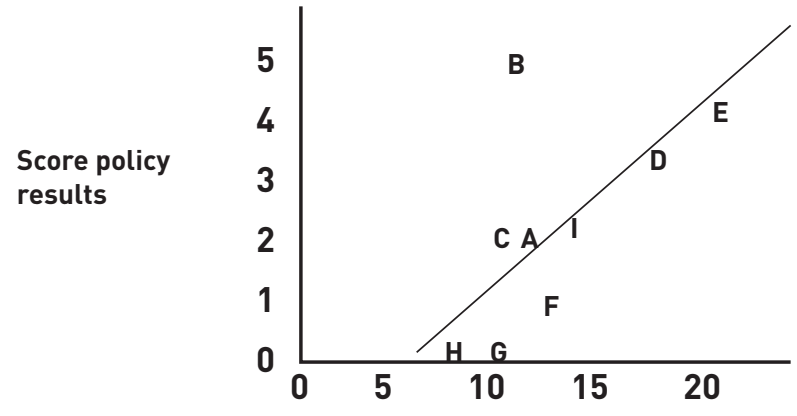

Impact / involvement during the coaching program

Graphic 1: Total score of impact and involvement during the coaching program on strategic, tactical and operational level versus the score on policy results of participating municipalities ( $N=9: \mathrm{A} t / \mathrm{m}$ I)

Table 1: ANOVA analyses pre- and posttest of determinants involving inter-sectoral collaboration $[\mathrm{N}=119]$

\begin{tabular}{|c|c|c|c|c|c|c|}
\hline & \multicolumn{2}{|c|}{$\begin{array}{l}\text { Pre minus post } \\
\mathrm{N}\end{array}$} & \multicolumn{2}{|c|}{$\begin{array}{l}\text { Participating } \\
\text { N }\end{array}$} & \multicolumn{2}{|c|}{$\begin{array}{l}\text { Non participating } \\
\mathrm{N}\end{array}$} \\
\hline \multicolumn{7}{|l|}{ Strategic level } \\
\hline $\begin{array}{l}\text { Political priority } \\
\text { laverage score; range: } 0-7 ; \text { a } 0.786\end{array}$ & 119 & $-0.08^{*}$ & 42 & $-0.45^{a}$ & 77 & $0.12^{b}$ \\
\hline $\begin{array}{l}\text { Administrative commitment } \\
\text { laverage score; range: } 0-3 ; a 0.713 \text { ) }\end{array}$ & 119 & 0.15 & 42 & 0.00 & 77 & 0.23 \\
\hline \multicolumn{7}{|l|}{ Tactical level } \\
\hline $\begin{array}{l}\text { Managerial support } \\
\text { Only civil servant Public Health } \\
\text { (average score; range: } 0-2 ; a 0.775 \text { ) }\end{array}$ & 14 & $-0.29 *$ & 3 & -0.66 & 11 & -0.18 \\
\hline $\begin{array}{l}\text { Organizational support } \\
\text { Only respondents with PHS contacts } \\
\text { laverage score range: } 0-7 ; \text { a } 0.732 \text { ) }\end{array}$ & 57 & -0.23 & 23 & 0.09 & 34 & $-0,44$ \\
\hline \multicolumn{7}{|l|}{ Operational level } \\
\hline $\begin{array}{l}\text { Attitude } \\
\text { (average score; range: } 0-4 ; \text { a } 0.831 \text { ) }\end{array}$ & 119 & 0.27 & 42 & 0,24 & 77 & 0.29 \\
\hline $\begin{array}{l}\text { Knowledge } \\
\text { laverage score; range: } 0-2 ; \text { a } 0.754 \text { ) }\end{array}$ & 119 & -0.03 & 42 & 0.10 & 77 & $-0,10$ \\
\hline $\begin{array}{l}\text { Self-efficacy } \\
\text { Only civil servant Public Health } \\
\text { (average score; range: } 0-4 ; \text { a 0.790) }\end{array}$ & 14 & -0.14 & 3 & 0.67 & 11 & -0.36 \\
\hline $\begin{array}{l}\text { Perceived expectations } \\
\text { Only civil servant Public Health } \\
\text { laverage score; range: } 0-19 ; \text { a } 0.887 \text { ) }\end{array}$ & 17 & 0.77 & 10 & 1.60 & 7 & $-0,42$ \\
\hline
\end{tabular}

a,b significant differences of averages with a column $=p<.0$ 


\section{HiAP at different system levels}

\section{The strategic level}

Comparing scores between coached and non-coached municipalities showed significant differences between pre- and post-test scores for political priority but not for administrative commitment. The political priority decreased in coached municipalities. During the intervention period two municipal executive (aldermen) with Public Health in their portfolio changed their positions.

\section{The tactical level}

All 32 municipalities showed significantly higher scores on the issue of managerial support for HiAP at the first measurement compared to the measurement 30 months later (see Table 2). Comparing scores from coached and non-coached municipalities showed no significant differences between pre- and post-test scores for managerial support and organizational culture, although civil servants from coached municipalities judged the cooperation with the regional PHS more positive, both at the start of the coaching program and still 30 months later In coached municipalities, managerial support decreased more compared to the non-coached municipalities (see Table 2). Compared to stakeholders at the other system levels, the managers were the least positive about the possibility of developing HiAP. In most municipalities the policy domain of Public Health is part of a department with a large scale of tasks. Only a very small part of the policy capacity of the department is available for Public Health (on average 8 hours a week (range 4-32)). The average available hours of coached civil servants increased slightly from 11 to 16 hours a week.

The in-depth interviews with managers of Public Health showed the importance of HiAP for their municipality. Managers stated that nobody should be against it. They said that HiAP and intersectoral collaboration requires an organizational change and emphasize that this is difficult to accomplish. Regarding the aspect of management support, only a few managers actively stimulated HiAP within their own department, experienced administrative support and they said that HiAP is translated in policy documents. At the tactical level collaboration with other policy domains is often absent, including collaboration with the PHS. Links to other policy domains are mainly forged at the level of municipal executive (aldermen) and civil servants. Managers feel themselves hierarchically responsible for Public Health, but their involvement on content is very limited and delegated. Managers ask the PHS to be more proactive in making municipalities aware of their expertise in the area of inter-sectoral collaboration to support municipalities in developing HiAP.

\section{The operational leve}

There were no significant differences in knowledge about HiAP, attitudes, self-efficacy and perceived expectations at the first measurement compared to the measurement 30 months later (see Table 2). Comparing scores between coached and non-coached municipalities showed no significant differences either between pre- and post-test scores, although the perceived expectations and self-efficacy of coached civil servants had increased, but not significantly due to low number of respondents (see Table 2).

\section{Table 2: ANOVA analyses pre- and posttest of determinants involving inter-sectoral collaboration targeting obesity} $(N=119)$

\begin{tabular}{|c|c|c|c|c|c|c|}
\hline & \multicolumn{2}{|c|}{$\begin{array}{l}\text { Pre minus post } \\
\text { N }\end{array}$} & \multicolumn{2}{|c|}{$\begin{array}{l}\text { Participating } \\
\text { N }\end{array}$} & \multicolumn{2}{|c|}{$\begin{array}{l}\text { Non participating } \\
\mathrm{N}\end{array}$} \\
\hline \multicolumn{7}{|l|}{ Integrated health policy on obesity } \\
\hline $\begin{array}{l}\text { Municipal priority obesity } \\
\text { (average score; range: } 0-3 ; \text { a } 0.817 \text { ) }\end{array}$ & 119 & 0.32 & 42 & 0.19 & 77 & 0.38 \\
\hline $\begin{array}{l}\text { Obesity in municipal consultation } \\
\text { (average score; range: } 0-3 ; \text { a } 0.783 \text { ) }\end{array}$ & 119 & 0.14 & 42 & 0.12 & 77 & 0.16 \\
\hline \multicolumn{7}{|c|}{ Obesity interventions within municipality } \\
\hline $\begin{array}{l}\text { Obesity interventions done } \\
\text { Only civil servants } \\
\text { laverage score; range: } 0-12 ; \text { a } 0.736 \text { ) }\end{array}$ & 31 & $1.10^{*}$ & 11 & 1.81 & 20 & 0.70 \\
\hline $\begin{array}{l}\text { Obesity interventions planned } \\
\text { Only civil servants } \\
\text { (average score; range: } 0-12 ; a 0.736 \text { ) }\end{array}$ & 31 & $-0.52^{*}$ & 11 & -0.36 & 20 & 0,60 \\
\hline
\end{tabular}

Forty-six percent of the civil servants not working in the Public Health domain do not have any ground in common with the obesity problem. Only a few civil servants state that they have the intention to develop HiAP interventions targeting obesity, such as stimulating a healthy school canteen, no license for fast-food companies near schools, no dogs allowed on playfields and healthy food instructions for people in debts $(23,27)$. During the intervention period six of the nine coached Public Health civil servants changed their positions. 


\subsection{Discussion}

This study provides insight into the effectiveness of a coaching program which was implemented in nine South Limburg municipalities in the Netherlands. We answered the question of whether municipalities are able to make progress in inter-sectoral collaboration at the strategic, tactical and operational level and in the assessment of HiAP proposals. We found that the coaching did not contribute to improvements in the determinants of inter-sectoral collaboration at the strategic and tactical level (see Table 2). On the contrary, the determinants in coached municipalities got worse, especially with respect to political priority and managerial support. At operational level self-efficacy and perceived expectations improved in coached municipalities whereas these factors decreased in the non-coached ones. Concrete for the health problem obesity the effects are stronger and more positive (see Table 1).

The results of the study further showed that there is a relation between log-book scores and HiAP proposals. In other words, more support and involvement of the stakeholders at each system level is related to the development of HiAP proposals (see Figure 2). Stakeholders at tactical level were difficult to involve and, in the eyes of coached civil servants the manageria support for HiAP decreased. Managers acknowledged this, simultaneously challenging the professionals of the regional PHS to show their expertise in HiAP and take the lead. Finally, we found that the coaching seemed to have positively contributed to the municipal priority setting of obesity and the actual implementation of HiAP interventions targeting obesity (see Table 1).

\section{Improvements of coaching program}

Looking back at the coaching program its final effect in general was very limited. There are different reasons for its failure. Firstly, our coaching program focused on stimulating the dialogue between different municipal policy domains, especially at the levels of civil servants and municipal executive (aldermen) with Public Health in portfolio. They were coached to search for possibilities to participate in the policy preparation process of other policy domains. However stimulating inter-sectoral collaboration requires involvement at the strategic, tactical and operational level, both vertically within a policy domain and horizontally with other policy domains (14). We may have insufficiently focused on horizontally organized managerial support. An interface between managers from the municipality and managers from the regional PHS was not created, making it difficult to create a sense of urgency for HiAP and to capitalize on opportunities for management support.

Secondly, the in-depth interviews with municipal managers revealed that they were prepared to invest in time and personnel if the merits of collaboration with other policy domains were made clear. Apparently, neither the trio that coached the municipalities nor the regional PHS have been able to show the merits of inter-sectoral collaboration, so far. The PHS should take this advice seriously and invest in competency and capability improvements of their professionals with respect to HiAP. Moreover, the very limited capacity within the municipality makes support from the regional PHS inevitable.

Thirdly, we did not formulate clear targets beforehand as we thought we would set these targets along with all stakeholders during the training sessions. No municipality dared to set fixed goals during the policy preparation process. This is not so remarkable because policy proposals merely state these goals in ambiguous terms e.g. of maximizing well-being. The goal-seeking process serves consensus and cooperation, both in terms of party politics and with various external groups (15). Recent literature however shows that clear health targets and instructions on how to reach these targets can stimulate inter-sectoral collaboration (28-30).

Fourthly, the Netherlands lacks a national strategy in which inter-sectoral collaboration is a formally established rule or law such as in the United Kingdom, Finland or Sweden $(29,31,32$. There are no public bodies at the national level that make HiAP a requirement apart from the permissive legislation of the Ministry of Health, Welfare and Sport (1). Therefore, at the local level HiAP is in its infancy and knowledge and skills improvements depend on goodwill. Thus far, Dutch municipalities are confronted with inadequately and insufficiently developed expertise 18 9). Municipalities are also not aware of the positive effects that health might have on the local economy and residents' participation $(31,33)$. Our coaching program incidentally contributed to some progress in self-efficacy and perceived expectations among civil servants but cannot structurally support the development of HiAP-expertise as long as there is no national obligation delegated to local public health bodies.

Finally, professional discontinuity, especially at operational level made it difficult to rais knowledge and skills within the municipality. In the eyes of civil servants the support from their manager was inadequate. Without such support professionals at the operational level have no authority to change their practices, even if they themselves should prefer to work more horizontally. Therefore, managerial support is essential for innovations (34).

\section{Opportunities to stimulate municipal inter-sectoral collaboration}

Literature shows the complexity of developing HiAP. The process needs coordination, focus and a long term horizon $(4,35)$. Moreover, within Dutch municipalities, Public Health has not been a strong or dominant policy framework for very long. The local economy, employment, or social security, for example, are dominant policy frameworks in which public and private bodies more or less automatically invest without external obligation. Policy actions focusing on behavioral lifestyle determinants are considered moralistic and may be politically controversial because 
they interfere in people's private lives $(30,36,37)$. For legitimization of public health, the environmental dimension of health should be more explicitly defined (38), thereby offering opportunities for HiAP proposals. This has to be explained by experts such as the regional PHS, because policy stakeholders often are not aware of the health impact of certain measures taken by, for instance, spatial planning (39). To counteract the weakness of the Public Health policy framework, a strong and long term commitment is needed from mayors and municipal executive (aldermen) including instituting decisive measures and resources regarding $\mathrm{HiAP}(30,40)$. They should also enforce adjusted performance indicators at tactical level that go beyond one's own policy domain $(4,12,29)$. The manager should ensure both vertical connections within their own policy domain and horizontal connections with other local policy domains and external partners $(41,42)$. Both the national government and local authorities should be aware that inter-sectora collaboration, which is necessary to develop HiAP, is not realistic without strong guidance. The poor results so for in developing HiAP are perhaps not so much due to the reluctance of nonpublic health policy domains, but rather because of powerlessness and lack of expertise in the domain of Public Health. Crucial in this context is the recognition that health does not have to be a primary goal in itself, but a means to other, more overarching community goals such as promoting social security, social cohesion, social inclusion and quality of life.

\section{Limitations of this study}

It appeared difficult to determine the effectiveness of a coaching program and to measure progress in HiAP within local governments (43). To our knowledge little research has been done nationally or internationally on HiAP by municipal stakeholders. The research is based on only 9 of the 418 municipalities in the Netherlands. There are no validated questionnaires to measure inter-sectoral collaboration. The Internet questionnaire developed for this study was based on theoretical insights and practical experience. The self-reported findings from the respondents can never completely rule out the risk of social desirability. Furthermore, the willingness to participate in this study fully depended on the delivery of email addresses by civil servants. The decision to participate in coaching was done on a voluntary basis, so municipalities that already had a positive attitude towards HiAP could have signed up for this program (selection bias). This better starting position may have influenced the results, because changes are then difficult to realize and coaching may have a negative effect because people realize how difficult HiAP is.

These results are a first indication of the possibilities for local government to participate in HiAP development. Future research is needed on how health can be connected to other policy domains, and what the positive and negative influences of health can be on the main targets of other policy domains.

\subsection{Conclusions}

The results show that the effects of the coaching program are in general very limited and uncertain although it had a small positive effect on HiAP proposals targeting obesity. Within municipalities HiAP proposals are not given a high priority, at the strategic level nor at the tactical level. The results of the study further showed that more support and involvement of stakeholders at each system level is related to the development of HiAP proposals.

Stimulating inter-sectoral collaboration in relation to specific health problems requires institutional involvement at all levels and not only with the Public Health sector. We therefore recommend to municipal management to get directly involved in the development of HiAP. With the energetic guidance on management level and input of knowledge and skills from the regional PHS, HiAP can perhaps be more successful than has been the case to date. Here lies a challenge for municipalities and their regional PHS. 


\subsection{References}

1. Wet Publieke Gezondheid, wet van 9 oktober 2008, houdende bepalingen over de zorg voor de publieke gezondheid. [Law on Public Health], (2008).

2. Ministerie van Volksgezondheid Welzijn en Sport. Gezond zijn, gezond blijven. Een visie op gezondheid en preventie. [Being healthy, staying healthy. National policy vision on health and prevention.]. Den Haag: Ministerie VWS; 2007.

3. van der Lucht F, Polder J. Van gezond naar beter. Kernrapport Volksgezondheid Toekomst Verkenning 2010 [Dutch Public Health Status and Forecasts Report 2010]. Bilthoven: Rijksinstituut voor Volksgezondheid en Milieu 2010.

4. Kickbusch I, McCann W, Sherbon T. Adelaide revisited: from healthy public policy to Health in All Policies. Health Promotion International 2008;23(1):Editorial 1-4.

5. Kickbusch I. Policy Innovation for Health. New York: Springer Science + Business Media; 2009.

6. RVZ, Onderwijsraad, Rob. Buiten de gebaande paden. Advies over intersectoraal gezondheidsbeleid, advies uitgebracht door de Raad voor de Volksgezondheid en Zorg, de Onderwijsraad en de Raad voor het openbaar bestuur. Zoetermeer 2009.

7. Smith KE, Bambra C, al e. "Partners in health? A systematic review of the impact of organizational partnerships on public health outcomes in England between 1997 and 2008. Journal of Public Health (Oxford) 2009;31(2):210-21.

8. Inspectie voor de Gezondheidszorg. Concept resultaten thematisch toezicht integraal beleid. [Concept results thematic inspection on integrated policy.]. 2008

9. Inspectie, Gezondheidszorg livd. Staat van de gezondheidszorg 2010. Meer effect mogelijk van publieke gezondheidszorg. (Health status 2010. More effect possible in public health.] Utrecht: Ministerie VWS; 2010.

10. Bekker MPM, Putters K, van der Grinten TED. Evaluating the impact of HIA on urban reconstruction decision-making. Who manages whose risks? Environmental Impact Assessment Review 2005;25(7-8):758-71.

11. Bekker M. The Politics of Healthy Policies: Redesigning Health Impact Assessment to Integrate Health in Public Policy. Rotterdam: Erasmus University Rotterdam; 2007.

12. Warner M, Gould N. Integrating health in all policies at the local level: using network governance to create 'Virtual Reorganization by Design'. In: Kickbusch I, editor. Policy Innovation for Health. New York: Springer; 2009. p. 125-63.

13. Zuid-Limburgse gemeenten. Samen gezond! Regionale prioriteiten Volksgezondheidsbeleid Zuid Limburg 2007-2011 [Together healthy! Regional Public Health Policy in South Limburg 2007-2011]. Maastricht 2007.

14. Jansen M. Mind the gap: collaboration between practice, policy and research in local public health. Maastricht: University Maastricht; 2007.
15. Stone DA, Stone DA. Policy paradox: the art of political decision making. New York: Norton \& Company; 2002.

16. Walt G. Health policy. An introduction to process and power. London: Zed books; 2004.

17. Kingdon JW. Agendas, alternatives and public policies. New York: Addison-Wesley Educational Publishers Inc. ; 2003.

18. Cummings TG, Worley CG. Organization development and change. Australia 2001.

19. Steckler A, Goodman RM, Kegler MC. Mobilizing organizations for health enchancement. In: Glanz K, Rimer BK, Lewis FM, editors. Health behavior and health education Theory, research and practice. 3 ed ed. San Francisco: Jossey-Bass; 2002. p. 335-60.

20. Fraser SW, Greenhalgh T. "Coping with complexity: educating for capability. British Medical Journal 2001;323(7316):799-803.

21. Bartholomew LK, Parcel GS, Kok G, Gottlieb NH. Planning health promotion programs, an intervention mapping approach. 2nd ed. San Francisco Jossey-Bass; 2006.

22. NIGZ, Limburg GZ, gemeenten Z-L. Masterclass Integraal Gezondheidsbeleid [Masterclass on integrated health policy]. Geleen: GGD Zuid-Limburg 2006.

23. Steenbakkers $M$, Jansen $M$, Maarse $H$, de Vries N. Lokaal integraal gezondheidsbeleid: intersectorale samenwerking vanuit het perspectief van gemeenten. Tijdschrift voor gezondheidswetenschappen 2010;88(3):136-43.

24. Steenbakkers M, Jansen M, Maarse H, De Vries N. Sturing op integraal gezondheidsbeleid: de rol van het gemeentelijke management. [The role of municipal departmental managers in achieving integrated health policy]. Tijdschrift voor gezondheidswetenschappen 2011; Accepted.

25. Steenbakkers M, Jansen M, Hesdahl B, ten Dam J, Maarse H. Gemeentelijke intersectorale samenwerking stimuleren: Lokale begeleiding bij het ontwikkelen van integraal gezondheidsbeleid. [Stimulating municipal government inter-sectoral collaboration: local support for the development of integrated health policy]. Tijdschriftvoor gezondheidswetenschappen 2011;89(5):266-73.

26. Steenbakkers $M$, Jansen $M$, Maarse $H$, De Vries N. Lokaal integraal gezondheidsbeleid: effecten van beleidsondersteuning op de ontwikkeling van gemeentelijke intersectorale samenwerking en integraal beleid. [Integrated local health policy: effects of local support on the development of municipal inter-sectoral collaboration and integrated health policy]. Tijdschrift voor gezondheidswetenschappen 2012;90(3):184-92.

27. van Assema P, Steenbakkers M, Rademaker C, Brug J. The impact of a nutrition education intervention on main meal quality and fruit intake in people with financial problems. Journal of Human Nutrition and Dietetics 2005 Jun;18(3):205-12.

28. de Leeuw E, McNess A, Stagnitti K, Crisp B. It's research, Jim, but not as we know it.. Acting at the Nexus. Integration of Research, Policy and Practice. Geelong: Deakin University 2007. 
29. St-Pierre L. Governance tools and framework for Health in All Policies. Québec: National Collaborating centre for Healthy Public Policy. European Observatory on Health Systems and Policies.2010.

30. Maarse JAM. Sturing op gezondheidsdoeleinden en gezondheidswinst op macroniveau Achtergrondstudie bij RVZ-rapport: Sturen op gezondheid. [Directing on health targets and health improvement on macro level. A background study by RVZ. Control on health.]. In: RVZ, editor.2011.

31. Storm I, Verweij A, Van der Lucht F. Integraal gezondheidsbeleid op lokaal niveau. Wat weten we en hoe nu verder? [Local integrated health policy. What do we know and how to proceed?]. Bilthoven: RIVM briefrapport 2701610042011.

32. Verweij A, den Broeder JM. Integraal gezondheidsbeleid samengevat [Integrated Health Policy summarized]. Bilthoven, : RIVM; 2006 [cited www.nationaalkompas.nl > preventie> thema's >integraal gezondheidsbeleid 13 maart 2006].

33. Nederland T, Dekker FPS. Verleiden tot gezondheid. Een integraal beleidsperspectief op gezondheidsbevordering. [Move to health. An integral policy perspective to health promotion.]. Utrecht: Verwey-Jonker Instituut 2011.

34. Jansen M, de Vries NK, Kok G, van Oers H. Samenwerking tussen beleid, praktijk en onderzoek in de publieke gezondheidszorg: resultaten van een multipe-case studie [Collaboration between policy, practice and research in local public health]. Tijdschrift voor gezondheidswetenschappen 2008;86(6):296-305

35. Hunter DJ. Leading for health and wellbeing: the need for a new paradigm. Journal of Public Health 2009;31(2):202-4.

36. Horstman K, Houtepen R. Worstelen met gezond leven. Ethiek in de preventie van hart- en vaatziekten. [Wrestling with living healthy. Ethics on the prevention of cardiovasculair diseases.]. Amsterdam: Het Spinhuis; 2005.

37. Hunter DJ. Zorg voor gezondheid vergt meer dan gezondheidszorg: de noodzaak van een nieuw paradigma [Care for health is more than health care: the need for a new paradigm]. G-lezing; 14 november; Utrecht 2007.

38. Commers M, Gottlieb NH, Kok G. How to change environmental conditions for health Health Promotion International 2006;22(1):80-7.

39. Aarts M-J, Jeurissen MPJ, van Oers H, Schuit AJ, van de Goor IAM. Multi-sector policy action to create activity-friendly environments for children: a multiple-case study. Health Policy 2011;101:11-9.

40. Rütten A, Röger U, Abu-Omar K, Frahsa A. Assessment of organizational readiness for health promotion policy implementation: test of a theoretical model. Health Promotion International 2009;24(3):243-51

41. Derksen W, Schaap L. Lokaal bestuur [Local government]. 5e druk ed: Elsevier; 2007.
42. Mannheimer LN, Lehto J, östlin P. Window of opportunity for intersectoral health policy in Sweden-open, half-open or half-shut? Health Promotion International 2007;22(4):307-15.

43. Barr V, Pedersen S, Pennock M, Rootman I. Health equity through intersectoral action: an analysis of 18 country case studies. WHO: Public Health agency of Canada 2008. 


\section{Hoofdstuk 7 -}

\section{Discussie}

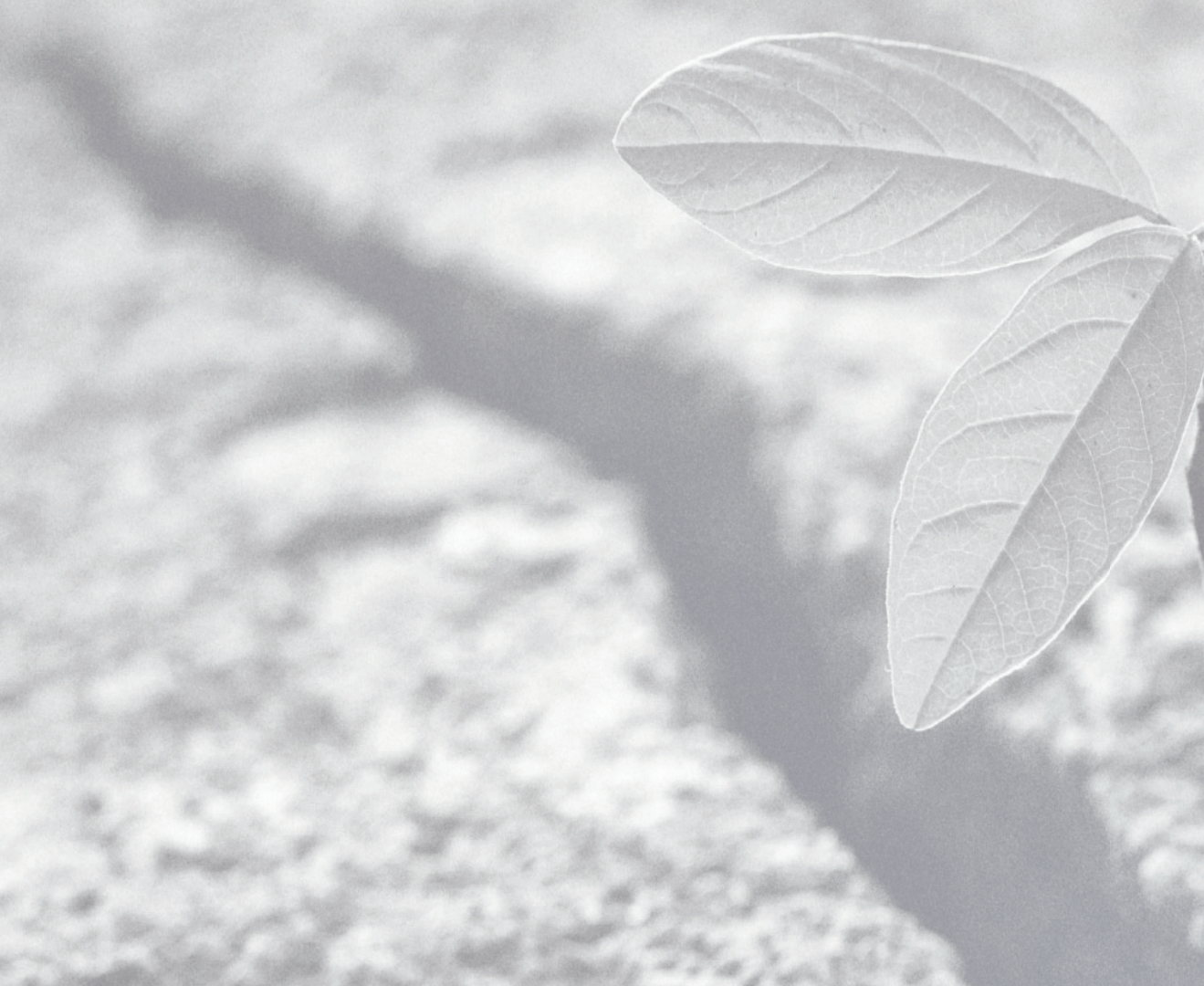

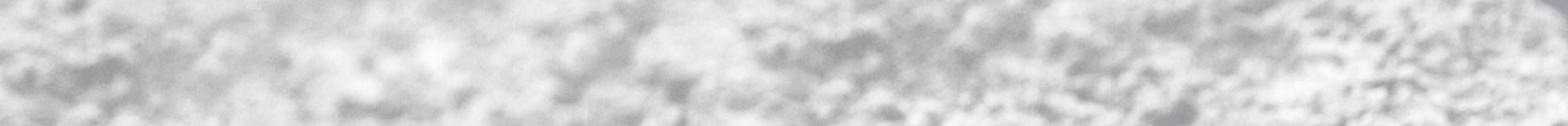
Hof

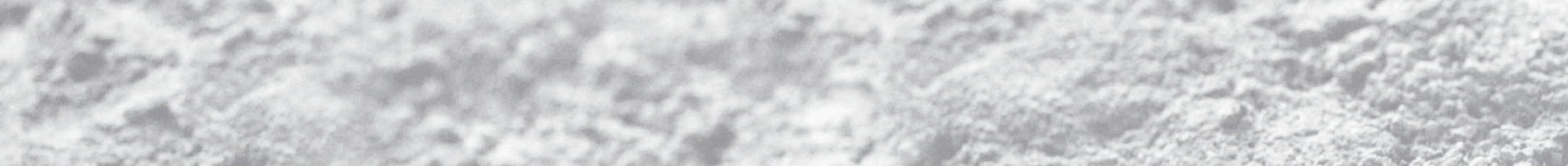

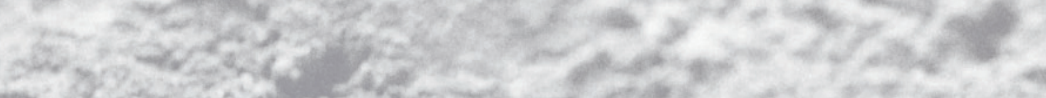
2.7.

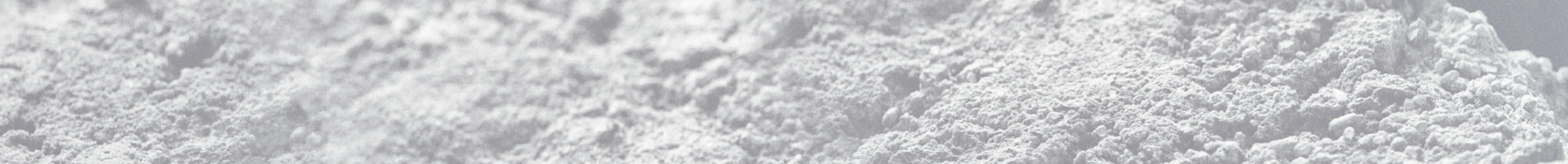

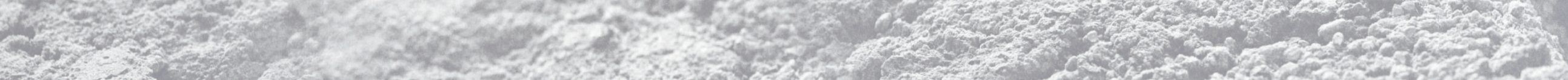

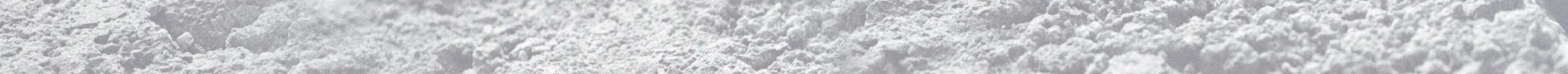

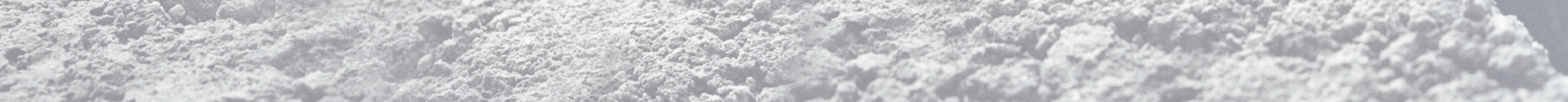

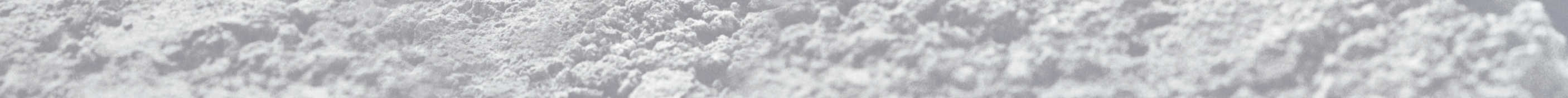

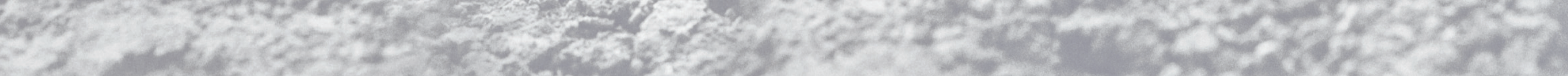
Ses $=08$ 


\subsection{Inleiding}

Dit onderzoek gaat over de mogelijkheden om de ontwikkeling van lokaal integraal gezondheidsbeleid te versterken. De hoofdvraagstelling is of gemeenten gestimuleerd kunnen worden tot meer intersectorale samenwerking en integrale beleidsontwikkeling voor het gezondheidsprobleem overgewicht. Om antwoord te krijgen op deze vraagstelling zijn negen Zuid-Limburgse gemeenten door de GGD Zuid Limburg intensief begeleid. Via actiebegeleidend onderzoek is het beleidsproces binnen deze negen gemeenten gevolgd en zijn tussentijdse bevindingen besproken, zodat het proces kon worden bijgesteld en aangestuurd. Om de effectiviteit van het begeleidingstraject 'Integraal gezondheidsbeleid overgewicht' (IGBO) (zie paragraaf 1.7) t kunnen bepalen is een effectevaluatie uitgevoerd bij Limburgse gemeenten. Voorafgaand en na afloop van de begeleiding zijn gemeentelijke actoren op strategisch, tactisch en operationeel niveau via een digitale vragenlijst bevraagd over integraal gezondheidsbeleid, algemeen en specifiek voor overgewicht. Managers met volksgezondheid in hun portefeuille zijn geïnterviewd over hun visie en houding ten aanzien van integraal gezondheidsbeleid en de ondersteuningsmogelijkheden van een GGD in dit beleidsproces. In dit proefschrift worden de resultaten van het in Zuid-Limburg uitgevoerde begeleidingstraject besproken. Met deze kennis wordt inzich verkregen in de gemeentelijke mogelijkheden om lokaal (integraal) gezondheidsbeleid te ontwikkelen en te implementeren. Intersectorale samenwerking wordt binnen dit onderzoek gezien als een voorwaarde om te kunnen komen tot integrale beleidsontwikkeling en besluitvorming. Hiervoor is verticale en horizontale samenwerking nodig tussen verschillende gemeentelijke afdelingen en de GGD.

In dit afsluitende hoofdstuk worden aan de hand van de centrale onderzoeksvraag en de verschillende deelvragen de voornaamste bevindingen van het onderzoek beschreven. De resultaten worden in een breder perspectief geplaatst en besproken met aanbevelingen voor de praktijk. Daarnaast wordt kritisch gereflecteerd op het uitgevoerde onderzoek en er worden aanbevelingen voor verder onderzoek gedaan. 
7.2 Beantwoording van de onderzoeksvragen

\section{Deelvraag 1:}

Hoe kijken gemeenten aan tegen intersectorale samenwerking en integraal gezondheidsbeleid?

Voorafgaand aan de start van het begeleidingstraject IGBO is medio 2007 bij Limburgse gemeenten onderzoek gedaan naar hun zienswijze over de mogelijkheden om binnen een gemeentelijke organisatie intersectoraal samen te werken om integraal gezondheidsbeleid te kunnen ontwikkelen (zie hoofdstuk 2). Bij de start van het begeleidingstraject was er in Nederland nog weinig onderzoek gedaan binnen gemeenten naar integraal gezondheidsbeleid. De literatuur geeft aan dat (gemeentelijke) intersectorale samenwerking vraagt om een dialoog tussen beleidsterreinen op zowel strategisch, tactisch als operationeel niveau (1-3). In dit onderzoek is een conceptueel model gebruikt dat speciaal is ontwikkeld om intersectorale samenwerking te meten binnen organisaties (2). Via een door ons ontwikkelde digitale vragenlijst is in 2007 - voorafgaand aan het begeleidingstraject IGBO - nagegaan of er verschillen bestaan tussen medewerkers van gemeenten die wel en niet gaan deelnemen aan het begeleidingstraject IGBO, verschillen tussen het beleidsterrein volksgezondheid (VGZ) en andere gemeentelijke beleidsterreinen én verschillen tussen gemeentelijke actoren op strategisch (portefeuillehouder/bestuurder), tactisch (afdelingsmanager) en operationeel (beleidsmedewerker) niveau.

Uit deze voormeting blijkt dat gemeenten die gaan deelnemen aan het begeleidingstraject op vrijwel alle determinanten van het conceptuele model beter scoren dan gemeenten die niet gaan deelnemen. Zo blijkt er meer politieke prioriteit en bestuurlijk draagvlak te zijn voor integraal gezondheidsbeleid, zijn er meer middelen en uren beschikbaar en is er een positievere houding, en zijn er meer kennis en vaardigheden aanwezig om integraal gezondheidsbeleid te ontwikkelen. Deze gemeenten lijken een betere uitgangspositie te hebben om intersectoraal samen te werken op strategisch, tactisch en operationeel niveau en lijken meer mogelijkheden te zien en beter in staat te zijn om vanuit VGZ een brug te slaan naar niet-VGZ beleidsterreinen. Tevens blijkt uit de voormeting dat van alle gemeentelijke actoren de afdelingsmanagers het minst positief zijn over integraal gezondheidsbeleid. Vaak ontbreekt op dit tactische niveau de samenwerking met andere beleidsterreinen, inclusief de GGD, en is er weinig draagvlak voor integraal beleid. Vooral op het niveau van de portefeuillehouder en beleidsmedewerker worden verbindingen gelegd met andere beleidsterreinen. Daarnaast wordt door portefeuillehouders, afdelingsmanagers en beleidsmedewerkers aangegeven dat samenwerking met maatschappelijke partners soms makkelijker tot stand komt dan de interne samenwerking met verschillende gemeentelijke beleidsterreinen. Inhoudelijke verdieping van de gemeentelijke intersectorale samenwerking aan de hand van het gezondheidsprobleem overgewicht maakt duidelijk dat de verschillende gemeentelijke beleidsterreinen niet bewust en vanuit parallelle belangen samenwerken. Gemeentelijke actoren werkzaam binnen aanpalende beleidsterreinen vinden het moeilijk om de thematiek overgewicht te koppelen aan eigen werkzaamheden. Als er al relaties zijn tussen beleidsactiviteiten VGZ en niet-VGZ worden ze door de verschillende gemeentelijke actoren vaak niet herkend. Aan de hand van een twaalftal voorbeeldinterventies is aan beleidsmedewerkers voorafgaand aan het begeleidingstraject gevraagd of deze interventies binnen de eigen gemeente worden uitgevoerd. Allemaal interventies die ingezet kunnen worden om overgewicht aan te pakken en waar bij de uitvoering van deze interventies intersectoraal moet worden samengewerkt. Enkele voorbeelden van dergelijke interventies zijn: geen vergunning verstrekken aan fastfood bedrijven bij scholen, realiseren van bewegingsstimulerende voorzieningen, via bijzondere bijstand financiële tegemoetkoming bieden voor sportactiviteiten stimuleren van gezonde schoolkantines en/of snoepbeleid op scholen en verbod instellen van honden op speel- en sportvelden. Het gaat hierbij dus om interventies die direct of indirect via beleid gedragsverandering kunnen stimuleren (4). Van deze interventies wordt minder dan de helft toegepast in gemeenten en blijken veel interventies onbekend te zijn bij beleidsmedewerkers (zie hoofdstuk 2). Uit de resultaten van de voormeting blijken gemeenten die begeleid willen worden een betere uitgangspositie te hebben voor het ontwikkelen van integraal beleid rond overgewicht, maar tegelijkertijd ontbreekt een intensieve samenwerking en betrokkenheid vanuit het tactische niveau op het vlak van integraal gezondheidsbeleid.

\section{Deelvraag 2:}

\section{Stimuleert lokale begeleiding gemeentelijke intersectorale samenwerking?}

Via een door de GGD Zuid Limburg en het NIGZ ontwikkeld begeleidingstraject zijn gemeenten bestuurlijk en ambtelijk ondersteund bij het bevorderen van de dialoog tussen gemeentelijke beleidsterreinen. Per gemeente is een lerend trio gevormd bestaande uit de beleidsmedewerker VGZ, een gezondheidsbevorderaar van de GGD en een medewerker van het NIGZ. Het accent lag op het ondersteunen van de eerste fasen van het beleidsproces: van beleidsvoorbereiding naar beleidsbepaling. Via actiebegeleidend onderzoek is het begeleidingstraject gedurende drie jaar (2007-2009) procesmatig geëvalueerd. Relevante informatie is verzameld via logboeken en verslagen van overleggen, trainingen en intervisiebijeenkomsten. Uit het evaluatieonderzoek blijkt dat integraal beleid de bestuurders en ambtenaren wel aanspreekt. Echter, zelfs met begeleiding slagen slechts weinig gemeenten erin om intersectorale samenwerking tussen beleidsterreinen tot stand te brengen. De belangrijkste knelpunten zijn het ontbreken van kennis, competenties en bestuurlijke en ambtelijke continuïteit (zie hoofdstuk 3). Het blijkt dat vooral de beleidsmedewerker VGZ de interne dialoog met andere beleidsterreinen is aangegaan en op zoek is gegaan naar nieuwe intersectorale beleidsafstemming rondom het gezondheidsprobleem overgewicht. Bij de start van het begeleidingstraject IGBO zijn afspraken gemaakt over de gewenste ureninzet van de beleidsmedewerker VGZ binnen het traject (2 uur per week), maar 
deze inzet is in geen enkele gemeente waargemaakt (gemiddeld nog geen $1 / 2$ uur per week). Gedurende de begeleidingsperiode zijn twee van de negen bestuurders, zes van de negen beleidsmedewerkers VGZ en vier van de negen gezondheidsbevorderaars van de GGD van functie gewisseld. Deze discontinuiteit heeft de uitwisseling van kennis en ervaringen bij de intervisiebijeenkomsten en de betrokkenheid bij het begeleidingstraject negatief beïnvloed. Elke wisseling geeft verlies aan kennis en vaardigheden over intersectoraal werken en integraal beleid. Uit de intervisiebijeenkomsten is naar voren gekomen dat de trio-leden het moeilijk vinden om een gezondheidsprobleem zoals overgewicht te verbinden aan andere gemeentelijke beleidsprioriteiten.

In zes van de negen gemeenten heeft het begeleidingstraject geleid tot concrete (integrale eindproducten (zie hoofdstuk 3). Concreet betekent dit dat er gezamenlijk is gewerkt aan de agendasetting van het gezondheidsprobleem overgewicht binnen andere beleidsterreinen, dat beleidsvoorbereidende stappen zijn ondernomen om de preventie van overgewicht vast te leggen in beleidsdocumenten van andere beleidsterreinen en dat vastgesteld beleid is geïmplementeerd. De gerealiseerde eindproducten per gemeente zijn voorzien van een score, waarbij score 1 staat voor 'afwezigheid van beleid' en score 5 voor 'integraal beleid dat wordt geïmplementeerd'. Twee gemeenten zijn voortijdig gestopt met het begeleidingstraject (score 0). Een gemeente heeft geen integraal beleid kunnen formuleren (score 1). In drie gemeenten is in de fase van beleidsformulering gezorgd dat gezondheid werd opgenomen in beleidsdocumenten (score 2). In een gemeente is in nauwe samenwerking tussen het beleidsterrein Ruimtelijke Ordening (RO) en VGZ een gezondheidstoets voor overgewicht ontwikkeld, waarover nog geen besluitvorming heeft plaatsgevonden (score 3). Binnen één gemeente is bestuurlijke toestemming verkregen voor deelname van de beleidsmedewerker VGZ aan multidisciplinair overleg in de ontwerpfase van bestemmingsplannen (score 4). Tenslotte is in één gemeente bestaand beleid, waarin de beleidsterreinen Sociale Zaken en VGZ gezamenlijke doelen hebben geformuleerd voor personen in de schuldsanering, uitgebreid. Het gaat hier om extra cursussen 'Goede voeding hoeft niet veel te kosten' (5), die voor uitvoering zijn ingekocht (score 5). Omdat het bestaand beleid betreft dat geïntensiveerd wordt, hoefde niet het gehele integrale beleidsontwikkelingsproces doorlopen te worden.

Om te achterhalen of er een relatie bestaat tussen geleverde inzet en betrokkenheid vanuit een gemeente en het gerealiseerde eindproduct is de score van het eindproduct gekoppeld aan de totaalscore voor inzet en betrokkenheid. Deze score is berekend op basis van de logboeken op strategisch, tactisch en operationeel niveau. Er blijkt een positief verband te bestaan tussen inzet en betrokkenheid vanuit alle systeemniveaus en de mate waarin gemeenten komen tot de ontwikkeling en implementatie van integrale beleidsvoorstellen. Als de inzet en betrokkenheid gedurende het begeleidingstraject evenwichtig is, dat wil zeggen als er zowel op strategisch, tactisch en operationeel niveau door de gemeente en de GGD is geïnvesteerd in intersectorale samenwerking, lijkt dit de ontwikkelmogelijkheden van integraal gezondheidsbeleid te vergroten. Maar gedurende het begeleidingstraject bleek het moeilijk om met andere beleidsterreinen gezamenlijk nieuwe beleidsdoelstellingen te formuleren en te implementeren en werden inzet en betrokkenheid van het management gemist.

Deelvraag 3:

Wat is de rol van het gemeentelijke management bij het ontwikkelen van integraal gezondheidsbeleid?

Uit de voormeting blijkt dat binnen een gemeente het tactische niveau (het management) niet of nauwelijks betrokken is bij integraal gezondheidsbeleid. Via diepte-interviews met 13 managers VGZ is daarom de rol van afdelingsmanagers VGZ geëxploreerd. De resultaten van dit onderzoek laten zien dat de afdelingsmanagers VGZ niet afwijzend staan tegenover intersectorale samenwerking en het formuleren van integraal gezondheidsbeleid. Het merendeel van de managers geeft aan een positieve houding te hebben ten aanzien van integraal beleid. Echter, slechts de helft van de managers stimuleert die samenwerking actief, zegt bestuurlijk draagvlak te ervaren en geeft aan dat integraal werken tot uiting komt in gemeentelijke beleids- en begrotingsdocumenten. Opmerkelijk is dat de intersectorale samenwerking met de GGD door het gemeentelijk management volledig gedelegeerd is naar het operationele niveau waar weinig en soms bijna geen beleidscapaciteit voor volksgezondheid aanwezig is (zie hoofdstuk 4). Daarbij komt dat de portefeuille VGZ binnen gemeenten is ondergebracht bij gemeentelijke afdelingen met diverse benamingen met meerdere inhoudelijke taakvelden, zoals onderwijs, cultuur, welzijn inclusief de Wmo en sport. Ook hebben beleidsmedewerkers VGZ vaak meerdere taken in het takenpakket, bijvoorbeeld Wmo en Wpg. Managers voelen zich vooral hiërarchisch verantwoordelijk (lijnmanagement) voor volksgezondheid, de inhoudelijke betrokkenheid is in de praktijk zeer beperkt en gedelegeerd.

Gemeentelijke managers VGZ vragen aan de GGD om haar expertise op het vlak van intersectorale samenwerking en integraal beleid explicieter kenbaar te maken aan gemeenten. Zonder gerichte inhoudelijke kennis over volksgezondheid en het belang van een integrale aanpak is het voor lijnmanagers moeilijk het interne beleidsproces aan te sturen en gezondheid structureel een plek te geven binnen andere beleidsterreinen. Managers geven aan behoefte te hebben aan concrete voorbeelden en praktische vertalingen van gezondheidsthema's, die aansluiten bij actuele maatschappelijke vraagstukken (zie hoofdstuk 4). Dit zou hen steunen bij het intern bepleiten en aansturen van intersectorale samenwerking en integraal gezondheidsbeleid. De afdelingsmanagers VGZ vragen de GGD nieuwe beleidsadviserende initiatieven te ontplooien om he tactische niveau inhoudelijk meer te betrekken bij beleidsoverstijgende gezondheidsthema's. 


\section{Deelvraag 4:}

Wat zijn de effecten van het uitgevoerde gemeentelijke begeleidingstraject 'Integraal gezondheidsbeleid overgewicht'?

Voorafgaand en na afloop van het begeleidingstraject IGBO is bij Limburgse gemeenten onderzocht hoe gemeenten aankijken tegen intersectorale samenwerking en het ontwikkelen van integraal gezondheidsbeleid. Portefeuillehouders, afdelingshoofden en beleidsmedewerkers verspreid over zes gemeentelijke beleidsterreinen zijn hierover via een digitale vragenlijst bevraagd (zie hoofdstuk 2 en 5 ).

Dit onderzoek laat zien dat het uitgevoerde begeleidingstraject IGBO om gemeenten te ondersteunen bij het ontwikkelen van integraal beleid zowel positieve als negatieve effecten heeft gehad (zie hoofdstuk 5 en 6). Vooral op strategisch en tactisch niveau is het commitment voor integraal gezondheidsbeleid afgenomen. Geconcretiseerd voor het gezondheidsprobleem overgewicht blijken de effecten iets positiever te zijn. Overgewicht heeft intern binnen de organisatie meer prioriteit gekregen, het thema wordt vaker besproken in ambtelijke overleggen en interventies worden significant vaker toegepast. Het begeleidingstraject heeft niet geleid tot het gebruik van bepaalde bestuurlijke instrumenten die intersectorale samenwerking kunnen bevorderen, zoals een wijziging in de organisatiestructuur, het beleidsproces, mandatering of financiële prikkels. Wel is vooral in begeleidingsgemeenten het aantal beschikbare uren van alle VGZ-beleidsmedewerkers toegenomen, maar deze extra uren zijn niet geïnvesteerd in het IGBO begeleidingstraject. Het is niet helder geworden wie binnen de gemeentelijke organisatie verantwoordelijk is voor intersectorale samenwerking en de ontwikkeling van integraal gezondheidsbeleid.

Gemeenten die hebben deelgenomen aan het begeleidingstraject hadden bij de voormeting een betere uitgangspositie om intersectoraal samen te werken op strategisch, tactisch en operationeel niveau en leken beter in staat om vanuit volksgezondheid een brug te slaan naar andere beleidsterreinen (zie hoofdstuk 2). Uit de procesevaluatie blijkt weliswaar dat in zes van de negen gemeenten het toegepaste begeleidingstraject heeft geleid tot concrete (integrale) eindproducten (zie hoofdstuk 3). Echter, op basis van de resultaten van de nameting (zie hoofdstuk 5 en 6) kan worden geconcludeerd dat de betere uitgangspositie en de gerealiseerde eindproducten gedurende het begeleidingstraject uiteindelijk niet hebben geleid tot meer intersectorale samenwerking en integraal beleid. Wel heeft het begeleidingstraject met name het operationele niveau positief beïnvloed; beleidsmedewerkers VGZ hebben een positievere houding gekregen, hoewel de kennis over integraal gezondheidsbeleid niet is veranderd. Het vertrouwen in eigen kunnen is afgenomen.

\section{Hoofd onderzoeksvraag:}

Kunnen gemeenten gestimuleerd worden tot meer intersectorale samenwerking en integrale beleidsontwikkeling voor het gezondheidsprobleem overgewicht?

De ontwikkeling van integraal gezondheidsbeleid staat (inter)nationaal nog in de kinderschoenen $(6,7)$. Dit beleidsterrein is relatief theoriearm; er is weinig onderzoek gedaan naar deze vorm van beleidsontwikkeling en er zijn geen eenduidige theoretische uitgangspunten beschikbaar om dit proces adequaat te conceptualiseren (8). Daar overgewicht een complex gezond heidsprobleem is, is binnen het begeleidingstraject gekozen voor een lerende ontwerpstrategie. Kenmerk van deze ontwerpstrategie is dat vorming en uitvoering van beleid (groten)deels gelijktijdig plaatsvinden

Concreet voor ons begeleidingstraject betekende dit dat uitvoeringsbeslissingen vaak zijn genomen op basis van beperkt beschikbare kennis en op dat moment aanwezige praktijkervaringen en niet uitsluitend op basis van gedegen wetenschappelijk onderzoek (9). Ondanks het feit da gemeenten die gingen deelnemen aan het begeleidingstraject een betere uitgangspositie hadden om intersectoraal samen te werken, slagen er slechts weinig gemeenten in om intersectorale samenwerking tussen beleidssectoren te realiseren. Gemeentelijke afdelingsmanagers waren minder positief over integraal gezondheidsbeleid en zonder inhoudelijke sturing van de manager is het moeilijk integraal gezondheidsbeleid te ontwikkelen.

Geconcludeerd kan worden dat het door ons uitgevoerde begeleidingstraject, dat gericht was op het aangaan van nieuwe vormen van samenwerking en afstemming tussen VGZ en niet-VGZ beleidsterreinen binnen een gemeentelijke organisatie, geen grote veranderingen teweeg heeft gebracht binnen de interne gemeentelijke samenwerkingsstructuren en -cultuur. De opzet en uitwerking van het lokale begeleidingstraject was onvoldoende krachtig om binnen een gemeente duurzame organisatieveranderingen te realiseren. Het uitgevoerde onderzoek heeft daarentegen wel interessante informatie opgeleverd over hoe er binnen een gemeente intersectoraal wordt samengewerkt op strategisch, tactisch en operationeel niveau en welke elementen dit beleidsproces beïnvloeden. Het onderzoek geeft aangrijpingspunten over de wijze waarop een integrale beleidsontwikkeling voor gezondheidsproblemen zoals overgewicht op lokaa niveau kan worden gestimuleerd en aangestuurd (zie de volgende paragraaf). 


\subsection{Aanbevelingen voor praktijk, beleid en onderzoek}

Het beschreven onderzoek leert ons dat intersectorale samenwerking en een integrale beleidsontwikkeling voor volksgezondheidsproblemen nog moeizaam verloopt binnen gemeenten. Om dit te verbeteren doen wij de volgende aanbevelingen.

Om intersectorale samenwerking binnen gemeenten te realiseren is commitment en duidelijke aansturing op zowel bestuurlijk als managementniveau intern binnen de eigen organisatie en in samenwerking met externe organisaties noodzakelijk.

In andere landen is reeds enige ervaring opgedaan met bestuurlijke instrumenten om intersectorale samenwerking te bevorderen (10-12). Dit zijn instrumenten die zich richten op verandering van organisatiestructuren, beleidsprocessen, financieringstructuren en mandaat. Instrumenten die hoofdzakelijk zijn bedoeld om nieuwe mogelijkheden tot onderlinge samenwerking te creëren om het proces van integrale beleidsontwikkeling te bevorderen. Essentieel in dit kader zijn (nieuwe) structurele vormen van overleg waarin gediscussieerd kan worden over (gezondheids)problemen, de invloed van andere beleidsterreinen op deze (gezondheids)problemen en het gezamenlijk ontwikkelen van beleid om deze problemen aan te pakken. Sturing van dergelijke integrale beleidsprocessen wordt bevorderd door heldere en gemeenschappelijke doelen en door aan te geven via welke aanpak deze doelen bereikt kunnen worden.

In de landen waar al ervaring is opgedaan met integraal gezondheidsbeleid, zoals bijvoorbeeld Finland, Noorwegen, Engeland en Canada, is vaak sprake van een nationale visie en strategie. In een dergelijke nationale visie wordt op het hoogste overheidsniveau aangegeven wat de (beleids)doelen zijn, hoe deze bereikt kunnen worden en wat verschillende beleidssectoren en externe partijen op lokaal, regionaal en nationaal niveau dienen bij te dragen $(6,12)$. Een zekere mate van bureaucratie lijkt de interne samenwerking binnen gemeenten positief te beïnvloeden. Hierdoor wordt namelijk duidelijker aangegeven wie welke kennis en deskundigheid in huis heeft en wie met wie moet samenwerken (13). Maar tegelijkertijd geeft de literatuur aan dat het bij complexe gezondheidsproblemen belangrijk is om ruimte te creëren om via een lerende ontwerpstrategie gezamenlijk te zoeken naar innovatieve oplossingen $(14,15)$. Dit wordt wel de 'neutral white space' genoemd: een veilige onderhandelingsruimte om samenwerkingsrelaties op te bouwen en te onderhouden en om samenwerkingspartners uit te nodigen voor discussie en samen te zoeken naar inhoudelijke verbindingen (15). Dit vraagt om interne beleidscapaciteit binnen gemeenten, enerzijds gewoon beschikbare uren van beleidsmedewerkers om te investeren in de interne horizontale dialoog en anderzijds voldoende beleidscompetenties (kennis, vaardigheden en senioriteit) om de interne dialoog te coördineren en aan te sturen.

Samengevat, integraal gezondheidsbeleid vraagt om sterk leiderschap op bestuurlijk niveau, een heldere visie op gezondheid en duidelijke doelstellingen, werken met nieuwe organisatiestructuren, inzet vanuit verschillende hiërarchische niveaus en voldoende middelen $(12,16)$. Uit ons onderzoek blijkt dat binnen gemeenten duidelijke sturing door sterk leiderschap en een heldere visie en doelstellingen ontbreken ten aanzien van het ontwikkelen van integraal gezondheidsbeleid. Portefeuillehouders VGZ spreken in de regel vaak heel makkelijk hun goedkeuring uit vóór integraal beleid, maar dragen dit niet altijd actief uit binnen het college van B\&W en/o de gemeenteraad. Het blijkt dat de huidige (inhoudelijke) overlegvormen tussen een GGD en gemeenten nu vrijwel uitsluitend op strategisch (bestuurlijk) en operationeel (beleidsmatig) niveau plaatsvinden $(17,18)$

Op basis van de bevindingen uit ons onderzoek bevelen wij gemeenten aan om de functionele verantwoordelijkheid voor het stimuleren van intersectorale samenwerking explicieter te benoemen, om te voorkomen dat niemand zich verantwoordelijk voelt voor de aansturing van het integrale beleidsproces $(19,20)$. Om meer samenwerking tussen beleidsterreinen, inclusief de GGD, te stimuleren is het in eerste instantie belangrijk om helder te formuleren wat er moet gebeuren. Dit betekent dat bestuurders op strategisch niveau daadkrachtig het belang van integrale gezondheidsdoelen moeten bepleiten, dat zij zorg dragen voor de formulering en besluitvorming van deze beleidsdoelen én hiervoor voldoende middelen (menskracht en financiën beschikbaar stellen $(21,22)$. Vervolgens sturen managers het proces aan over hoe dit beleid wordt geïmplementeerd. De manager vervult een brugfunctie tussen bestuurder en beleidsmedewerker en dient te zorgen voor verticale aansturing en daarnaast ook voor horizontale verbindingen met andere gemeentelijke beleidsterreinen en externe samenwerkingspartners $(23,24)$.

Door integrale gezondheidsdoelen inhoudelijk te verbinden aan gemeentelijke programma- en begrotingsdocumenten wordt interne en externe aansturing van het gemeentelijke beleid gelegitimeerd en kan integraal gezondheidsbeleid beter verankerd worden binnen de gemeentelijke organisatie. Zonder een dergelijke inhoudelijke verbinding blijft de ontwikkeling van integraal gezondheidsbeleid nog te veel een uitdaging voor individuele actoren binnen een gemeentelijke organisatie zonder een officiële status. Zonder inhoudelijke kennis over volksgezondheid en het belang van een integrale aanpak is het moeilijk voor een lijnmanager om de beleidsmedewerker adequat te faciliteren en te stimuleren. Hierdoor is het vrijwel onmogelijk voor een beleidsmedewerker om binnen de eigen organisatie met andere beleidssectoren samen te werken en gezamenlijk met collega's integraal gezondheidsbeleid te formuleren. Een regio-GGD werkend vanuit een regionale gemeenschappelijke regeling (GR) heeft nu vaak geen structureel overleg met het lijnmanagement VGZ of aanpalende beleidsterreinen van (centrum)gemeenten, maar 
het is aan te bevelen om een dergelijk overleg wel te initierren. Hierbij dienen dan ook externe samenwerkingspartners uit de regio betrokken te worden. Denk hierbij aan zorgverzekeraars, huisartsen en zorgprofessionals maar ook aan woningbouwcorporaties, welzijnswerk en sport Doel van een dergelijk tactisch overleg tussen partijen is om te komen tot regionale afstemming en te voorzien in noodzakelijke randvoorwaarden voor de beleidsontwikkeling en -uitvoering

De meerwaarde van intersectorale samenwerking voor het ontwikkelen van (integraal) gezondheidsbeleid is onvoldoende bekend bij gemeenten. 'Best-practices' zijn belangrijk om gemeenten te kunnen overtuigen van deze meerwaarde.

Binnen het openbaar bestuur is publieke gezondheid een van de vele beleidsterreinen, naast o.a. ruimtelijke ordening, veiligheid, onderwijs, sport en recreatie. De politieke beleidsagenda is meestal overvol en wordt mede bepaald door actualiteit en urgentie. De GGD kan de politieke prioriteit voor regionaal of lokaal gezondheidsbeleid benadrukken door bijvoorbeeld een regionale Volksgezondheid Toekomst Verkenning (VTV) voor haar gemeenten te ontwikkelen (25). Maar dergelijke objectieve kennis over aard en omvang van lokale gezondheidsproblemen en hun oplossingen alleen blijken niet automatisch te leiden tot meer (integraal) gezondheidsbeleid. Een regionale VTV is geen wondermiddel omdat dergelijke cijfers vaak symbolisch worden gebruikt en zonder een goede beleidsadvisering niet automatisch worden omgezet in (integraal) gezondheidsbeleid (26). Uit ons onderzoek blijkt dat verschillende gemeentelijke beleidsterreinen niet bewust en vanuit parallelle belangen samenwerken aan de aanpak van overgewicht (zie hoofdstuk 2). Veel beleidsterreinen zijn zich niet bewust van de invloed die het eigen beleid heeft op de publieke gezondheid, waardoor intersectorale samenwerking niet vanzelfsprekend plaatsvindt $(27,28)$

Het uiteindelijke doel van intersectorale samenwerking en integrale beleidsontwikkeling is het realiseren van gezondheidswinst maar aangezien het ontwikkelen van integraal (gezondheids)beleid een incrementeel proces is, is het belangrijk om ook tussentijdse uitkomstmaten te benoemen Dit kan bijvoorbeeld door intersectorale samenwerkingsnetwerken te creëren, bestuurlijk en ambtelijk draagvlak voor maatschappelijke participatie publiekelijk uit te dragen of door de kosten van een maatschappelijke business case te monitoren (een kosten-baten analyse). Een landelijke inventarisatie van 'best-practices' over zowel tussentijdse als einduitkomsten is belangrijk, omdat dit mogelijkheden biedt om kennis en ervaringen met elkaar te delen. Gemeentelijke managers geven aan behoefte te hebben aan concrete voorbeelden en praktische vertalingen van gezondheidsproblemen naar maatschappelijke vraagstukken. Een goed voorbeeld is de in Zuid-Limburg ontwikkelde integrale interventie 'Goede voeding hoeft niet veel te kosten' (zie tekstblok 7.3.1) (5)
Een goed voorbeeld van intersectorale samenwerking is het project 'Goede voeding hoeft niet veel t kosten' dat via de Kredietbank Limburg wordt uitgevoerd en dat zich richt op mensen met een lage sociaal-economische status (ses) (5). 'Goede voeding hoeft niet veel te kosten' is een vast onderdeel van de budgetteringscursus 'Rondkomen met inkomen' van de Kredietbank Limburg. Deze budgetteringscursus is bedoeld voor mensen met financiële problemen die in een schuldsaneringtraject zijn opgenomen. Ongeveer de helft van de deelnemers heeft een lage opleiding en weinig inkomen oftewel een lage ses. Gemeenten, de afdeling Sociaal-Economische Zaken, kopen de totale budgetteringscursus in bij de Kredietbank, inclusief het voedingsonderdeel. Het koppelen van gezondheidsbeleid aan sociaal-economisch beleid, in een periode die gekenmerkt wordt door financiële crisis, werkloosheid en inkomensachteruitgang, maakt dit project extra relevant en een voorbeeld voor andere GGD'en. In 2009 heeft deze intersectorale interventie de landelijke erkenning gekregen van 'theoretisch goed onderbouwd'(29).

Tekstblok 7.3.1.: 'Best-practice'. 'Goede voeding hoeft niet veel te kosten'(5)

Deze interventie is inmiddels binnen meerdere gemeenten in Nederland geïmplementeerd. De intersectorale samenwerking tussen de gemeentelijke beleidsterreinen Sociale Zaken en VGZ laat een duidelijke meerwaarde zien. Via deze interventie kan een moeilijk bereikbare doelgroep worden bereikt. Mensen met financiële problemen wordt geleerd om met een beperkt budget gezond te eten en verantwoord om te gaan met financiële middelen. In 2003 heeft deze interventie de landelijke stimuleringsprijs openbare gezondheidszorg (OGZ) gewonnen. Deze "bestpractice' heeft inmiddels de landelijke erkenning van theoretisch goed onderbouwd gekregen op basis van een positieve effectevaluatie. In 2012 wordt het onderzoek naar de effectiviteit van deze interventie herhaald om in aanmerking te kunnen komen voor de landelijke erkenning van bewezen effectieve interventie ('evidence-based') (29)

Wij bevelen gemeenten aan om vergelijkbare kleinschalige innovatieve interventies als 'Goede voeding hoeft niet veel te kosten' te ontwikkelen. Op lokaal niveau kunnen gemakkelijk nieuwe inhoudelijke verbindingen worden gelegd tussen verschillende beleidsterreinen en kleinschalige experimenten worden uitgevoerd. Tevens kunnen gemeenten hun GGD of Academische Werkplaats vragen om dergelijke experimentele interventies te begeleiden met praktijkgericht evaluatieonderzoek. Op termijn kunnen lokaal ontwikkelde interventies mogelijk dan ook regionaal of landelijk worden geïmplementeerd. Dergelijke 'best-practices' zijn belangrijk om gemeenten te kunnen overtuigen van de meerwaarde van intersectorale samenwerking voor het ontwikkelen van integraal beleid. 
Door de beperkte beleidscapaciteit voor publieke gezondheid en door ambtelijke discontinuitteit worden de verschillende beleidsrollen binnen gemeenten niet adequaat vervuld. Gemeenten kunnen hun wettelijke regiefunctie voor publieke gezondheidstaken delegeren naar de $G G D$.

De portefeuille VGZ is binnen gemeenten ondergebracht bij afdelingen met diverse benamingen en een breed takenpakket (zie hoofdstuk 4). De beleidsmedewerker VGZ is vaak ook werkzaam op het gebied van bijvoorbeeld Wmo, sport, onderwijs of jeugd, zeker in kleinere gemeenten. In vergelijking met de beschikbare capaciteit van de totale gemeente is er voor volksgezondheid weinig tot bijna geen beleidscapaciteit beschikbaar (range 0.2 - 0.8 FTE). Daarbij komt dat een beleidsmedewerker VGZ verschillende rollen kan vervullen binnen het gemeentelijke beleidsproces; namelijk die van adviseur, regisseur, makelaar, aanjager en bewaker. De keuze van de rol hangt af van de manier waarop de intersectorale samenwerking vorm krijgt in een gemeente (30).

Beleidsmedewerkers geven zelf aan meestal de regisserende rol te hebben in de beleidsontwikkeling en -uitvoering omdat dit in de wet zo is aangegeven (31). Of men de makelaarsrol vervult, netwerken opzet of deze onderling verbindt en onderhoudt, hangt af van de aanwezige competenties (kennis, vaardigheden en ervaring) en de beschikbare beleidscapaciteit. Het leggen van verbindingen tussen problemen en oplossingen en het bij elkaar brengen van (regionale of lokale) partijen gaat niet vanzelf en vraagt om expertise en tijd (15). Beleidsmedewerkers vervullen nauwelijks of niet de rol van aanjager om gezondheid te agenderen binnen gemeentelijke beleidssectoren en partijen buiten het volksgezondheidsdomein. Ook de bewaakrol om gezondheidseffecten te signaleren in bestuurlijke beslissingen, wordt nauwelijks ingevuld (30). Voor het adequaat doorlopen van het beleidsproces is het echter wel belangrijk dat er agenda-setting plaatsvindt van een maatschappelijk probleem (aanjagen), er op een integrale manier gewerk wordt aan de beleidsformulering (adviseren, verbinden en regisseren) en dat het beleid adequaat wordt uitgevoerd en geëvalueerd (regisseren en bewaken) (zie paragraaf 1.2). Uit onderzoek van de inspectie (32) blijkt dat de gemeentelijke beleidsregie versterkt dient te worden. Gemeenten hebben vanuit de wet de regierol ten aanzien van lokaal gezondheidsbeleid, echter zowel gemeentebestuurders als GGD directeuren vinden dat gemeenten onvoldoende sturen op lokale beleidsdoelen (33). Hierdoor is er nog onvoldoende sprake van consistent beleid en sluiten gezondheidsbeleidsdoelen en -maatregelen nog te weinig aan bij belangrijke maatschappelijke vraagstukken. Daarbij komt dat de ambtelijke discontinuïteit binnen het beleidsterrein VGZ groot is. Dit beïnvloedt het beleidsproces negatief en hierdoor is het moeilijk om kennis en expertise op te bouwen op het vlak van de publieke gezondheid, laat staan om actief de inter- sectorale samenwerking te stimuleren. Landelijk worden steeds meer wettelijke zorgtaken gedecentraliseerd naar gemeenten, denk aan Wmo in 2007 en in 2014 de jeugdzorg. Deze decentralisatie versterkt de gemeentelijke autonomie om beleid beter af te stemmen op lokale behoeften en mogelijkheden. Maar tegelijkertijd groeit de krapte qua ambtelijke ondersteuningsmogelijkheden om de beleidsontwikkeling en -uitvoering van deze zorgtaken te regisseren

Van oudsher ondersteunt de GGD de gemeenten bij het uitvoeren van haar wettelijke taken en zien gemeenten de GGD als hun expertisecentrum en aanspreekpunt op het vlak van de VGZ (hoofdstuk 4). Regionaal en lokaal wordt de GGD vanuit haar inhoudelijke expertise gevraagd door gemeenten om mede sturing en invulling te geven aan diverse lokale en regionale samenwerkings- en beleidsprocessen. Naast de traditionele ondersteunende en uitvoerende rol van de GGD voor gemeenten is er dus ook steeds vaker sprake van een beleidsadviserende rol laanjagen en bewaken) en -coördinerende rol (regisseren en makelaar zijn) $(17,34)$. Het feit is dat gemeenten niet altijd in staat zijn of de ambitie hebben om de regionale of lokale uitvoeringsregie ook daadwerkelijk vorm te geven. Gezien de beperkte beleidscapaciteit en de ambtelijke discontinuïteit is het aan te bevelen dat gemeenten de regiefunctie voor de Wpg nadrukkelijker in samenwerking met haar GGD uitvoert of als een bestuurlijke opdracht delegeert naar de GGD. Een gemeenschappelijke regeling (GR) kan dan een prima instrument zijn om wettelijke beleidsmatige en/of uitvoerende publieke gezondheidstaken te delegeren vanuit de gemeente naar de GGD. Als de GGD deze taak gedelegeerd krijgt, bevelen wij aan om de samenwerking tussen het gemeentelijke beleidsterrein VGZ en de GGD niet vrijblijvend te laten zijn, maar bestuurlijk en manageriek duidelijke afspraken te maken over ieders inzet, taken en verantwoordelijkheden op strategisch, tactisch en operationeel niveau. Wanneer gemeenten zelf onvoldoende in staat zijn het beleidsproces adequaat te begeleiden kan aanvullende inzet en betrokkenheid van GGD-professionals een adequate aanvulling zijn. Essentieel is dat GGD en gemeente intensief gebruik maken van elkaars kennis en kunde, in alle fasen van de beleids cyclus, en zowel gevraagd als ongevraagd omdat lokaal bestuur en verlengd lokaal bestuur elkaar nodig hebben.

De competenties van de GGD beleidsmedewerker dienen te worden versterkt.

Volgens de Wpg dienen gemeenten voordat ze besluiten nemen die gevolgen kunnen hebben voor de publieke gezondheid advies hierover aan te vragen bij de GGD. En een GGD kan proactief en ongevraagd advies uitbrengen aan gemeenten. Maar in de praktijk adviseert een GGD zelden ongevraagd en laten gemeenten hun bestuurlijke besluiten slechts in beperkte mate toetsen op 
gevolgen voor de publieke gezondheid $(35,36)$. In dit kader raden wij GGD'en aan veel actiever op te treden in het bewaken van de publieke gezondheid en het (on)gevraagd adviseren van het gemeentelijke lijnmanagement. Daarbij dienen GGD'en te denken vanuit maatschappelijke vraagstukken die voor gemeenten een hoge politieke prioriteit hebben en samen met gemeenten te zoeken naar vernieuwende inzichten en oplossingen voor deze vraagstukken. Dit vraagt om een andere houding en benadering van GGD'en naar gemeenten toe. Gemeenten ervaren nu soms een zekere mate van naïviteit bij GGD-professionals, omdat bij laatstgenoemden de geneigdheid bestaat om (publieke) gezondheid te betitelen als het meest belangrijke beleidsthema (28). Het ambitieniveau van de gemeente met betrekking tot volksgezondheid sluit in de praktijk vaak onvoldoende aan bij de aanwezige visie en beleidsprioritering van de GGD.

De magere resultaten tot dusver met betrekking tot intersectorale samenwerking en integraal gezondheidsbeleid zijn wellicht niet zozeer het gevolg van onwil van gemeentelijke actoren binnen aanpalende beleidsterreinen, maar eerder van onmacht en onkunde van professionals binnen het beleidsterrein VGZ. Wil de GGD in de toekomst haar beleidsfunctie voor gemeenten versterken, in nauwe samenwerking met of als bestuurlijke opdracht van gemeenten, dan is he aan te bevelen dat de GGD haar eigen professionaliteit verbreedt en toegroeit naar een breed inzetbare dienstverlening. Naast uitvoerende taken voert de GGD ook coördinerende (regisseuren makelaarsrol), adviserende en beleidsvoorbereidende (aanjaag- en bewaakrol) taken uit in opdracht van haar gemeenten en in nauwe samenwerking met andere lokale samenwerkingspartners (30)

Door meer proactief en outreachend (niet uitsluitend op verzoek) te gaan werken kan de GGDprofessionaliteit worden ingezet bij het zoeken naar oplossingen voor maatschappelijke vraagstukken. Zo dienen de effecten van (integraal) gezondheidsbeleid op andere gemeentelijke beleidsterreinen, zoals bijvoorbeeld de Wmo of het jeugdbeleid, nader te worden onderzocht en bediscussieerd met gemeenten. Daarnaast dient de GGD de invloed van andere beleidsterreinen op gezondheid duidelijker te bestuderen. Dit betekent dat de inhoudelijke focus in de toekomst meer gelegd moet worden op het veranderen van de sociale en fysieke omgeving, waarmee burgers verleid kunnen worden tot gezond gedrag, en minder op het beïnvloeden van een gezonde leefstijl bij individuen. Dit vraagt om andere competenties en vaardigheden van GGDprofessionals en zal ook vertaald moeten worden in hun opleidingstrajecten. Concreet betekent dit dat een GGD-professional in staat is tot:

- aanjagen: monitoren van gezondheidsgegevens en sociale determinanten, benoemen en agenderen van deze prioriteiten binnen het VGZ-beleidsterrein maar ook binnen andere beleidsterreinen

- adviseren: adviseren over beïnvloeding van gezond gedrag via de sociale en fysieke omgeving:
- verbinden: verwerven van inzicht in het gemeentelijke beleidsproces (op detailniveau) en dit proces beoordelen op kansen en mogelijkheden voor gezondheidsbeleid, bijvoorbeeld doo Wmo doelen te koppelen aan Wpg doelen en deze praktisch te vertalen naar uitvoeringsprogramma's. Hetzelfde kan plaatsvinden voor doelen op het terrein van werkgelegenheid, ruimtelijke ordening, verkeerveilige mobiliteit, huisvesting en sociale veiligheid;

- regisseren: realiseren van uitvoeringsplannen en aansturen van afstemming tussen publieke en private partijen in het domein van de zorg maar ook met partijen buiten het domein van de zorg;

- bewaken: signaleren van gezondheidseffecten in bestuurlijke beslissingen en hierover gevraagd en ongevraagd adviseren.

Het management van de GGD wordt aanbevolen om te voorzien in dergelijke competentieverbeteringen en om een duidelijkere taakverdeling en samenwerkingsafspraken met gemeenten te maken. Als verlengd lokaal bestuur en gemeentelijk expertise-centrum op het vlak van de publieke gezondheid ligt hier een uitdaging voor de GGD.

Het begrip integraal gezondheidsbeleid dient anders te worden 'geframed' en gezondheid dient meer vanuit integraliteit te worden benaderd.

Met de aanbevelingen om commitment en sturing te versterken, 'best-practices' als voorbeeld aan te reiken, de beleidscapaciteit te verhogen en de competenties van GGD-medewerkers t verbeteren zijn we er echter niet. Zoals in de inleiding is geschetst is de publieke gezondheidszorg geen dominant 'policy frame'. Gezondheid heeft eerder een individuele connotatie dan een collectieve en het lijkt dus eerder een individuele dan een collectieve verantwoordelijkheid te zijn. Volksgezondheid staat momenteel bij geen enkel beleidsterrein hoog op de agenda staat $(22,37)$. Dit feit kan wellicht deels te maken hebben met hoe we gezondheid in politieke zin 'framen'. Een 'frame' is een inhoudelijke politieke boodschap, die in het politieke debat word gebruikt en tot een specifieke interpretatie van de werkelijkheid leidt, waarbij bepaalde aspecten worden uitvergroot en andere worden weggedrukt (38). 'Framing' beïnvloedt dus de manier waarop mensen denken over een bepaald thema, hun percepties en de wijze waarop bepaalde informatie geïnterpreteerd wordt, en 'framing' gaat verder dan het aanleveren van informatie op basis waarvan keuzes gemaakt kunnen worden $(39,40)$.

Tot nu toe leggen gezondheids- en GGD-professionals het inhoudelijke probleem vrijwel altijd uit in termen van gezondheidsverlies, gezondheidsrisico's, vermijdbare ziekte en sterfte. Gezondheidsproblemen worden inhoudelijk zelden vertaald in verlies van arbeidsproductiviteit, 
onvolwaardige maatschappelijke participatie of toegenomen inkomensverschillen. $\mathrm{Er}$ is wel langzaam aan een kentering merkbaar. Zo gaat de laatste VTV wel in op gezondheidswinst in termen van arbeidsproductiviteit etc. $(25,41)$. De regionale nota's en de lokale uitvoeringsplannen daarentegen blijven insteken op leefstijlrisico's zoals alcohol, roken, voeding, bewegen en depressie. Door de aanpassing van de Wpg moeten lokale nota's deze landelijke speerpunten overnemen. Hierin schuilt het gevaar dat de boodschap van de lokale nota die in het politieke debat wordt gebruikt, geïnterpreteerd wordt als zijnde een individuele verantwoordelijkheid. De lokale politiek kan nog instemmen met een beperkte mate van ondersteuning, maar wezenlijke beleidseffecten komen daarmee niet tot stand. Dit is misschien ook de reden waarom de sociaal-economische gezondheidsverschillen de laatste decennia niet zijn afgenomen, integendeel, ze zijn iets toegenomen.

Gemeenten en GGD zouden de gezondheidsboodschap wellicht beter kunnen vertalen ('framen') in termen van maatschappelijke participatie van burgers, omdat dit voor gemeenten een steeds dominanter 'policy frame' wordt. Mensen worden gestimuleerd om ondanks de aanwezigheid van bepaalde sociale, fysieke of emotionele beperkingen actief te blijven participeren in de samenleving (42). Voor de jeugd betekent dit deelname aan onderwijs, voor volwassenen aan werk, en voor ouderen aan mantelzorg en sociale activiteiten. Essentieel in dit kader is om te erkennen dat gezondheid niet een primair doel hoeft te zijn, maar een middel om andere meer overkoepelende gemeentelijke doelen te realiseren, zoals vergroting van het arbeidspotentieel, verbetering van leerprestaties, sociale veiligheid, sociale cohesie en leefbaarheid en reductie van sociaaleconomische gezondheidsverschillen (41). Inhoudelijk gezien zijn er veel aangrijpingspunten binnen de verschillende gemeentelijke beleidsterreinen om gezondheid anders te 'framen'; denk aan het plezier van groen in de wijk, de gezelligheid van spontane ontmoetingen bij speelvoorzieningen, een sociaal veilig horecabeleid, een wandel- en fietsvriendelijke maar autoluwe schoolomgeving, veilige fietsroutes, frisse lucht in klaslokalen waardoor leerprestaties omhoog gaan etc. Door bijvoorbeeld niet uitsluitend het accent te leggen op gezonde voeding maar vooral te kijken naar goedkope voeding, wordt een project zoals 'Goede voeding hoeft niet veel te kosten' al meer dan tien jaar succesvol uitgevoerd binnen de gemeente Maastricht (zie tekstblok 7.3.1.).

Het 'framen'van publieke gezondheidsproblemen dient meer aandacht te krijgen en het begrip integraal gezondheidsbeleid kan hierbij behulpzaam zijn (40). In dit kader is het wellicht beter om niet te spreken van integraal gezondheidsbeleid maar van integraal beleid. 'Framing' en agenda-setting hebben invloed op elkaar (43). Zo kan de manier waarop een gezondheidsprobleem in de media wordt beschreven, aanleiding zijn om het op de politieke agenda te plaatsen Hierbij is een zeker opportunisme aan te bevelen, waarmee we bedoelen dat problemen zodanig vertaald kunnen worden dat ze beter aansluiten bij de politieke prioriteiten. Als werkgelegenheid een politiek belangrijk thema is kunnen gezondheidsproblemen in die richting beschreven worden. Zo kunnen kansen tot samenwerking ontstaan en verbindingen worden gelegd, daar waar deze zich voordoen. Zo'n werkwijze wordt ook wel omschreven in termen van een 'window of opportunity' $(23,44)$

In het beleidsproces moeten problemen en oplossingen actief met de verschillende beleidsterreinen en externe partners gecommuniceerd worden en op een passende wijze worden gepresenteerd (15). Een beleidsentrepreneur of 'policy entrepreneur', beschikt over de kwaliteiten om die verbindingen te leggen en problemen op de best passende manier te 'framen' $(45,46)$ Concreet betekent dit dat een beleidsentrepreneur het beleidsproces beïnvloedt door gezondheidsproblemen zodanig te vertalen dat deze op de agenda worden geplaatst, dat oplossingen zo worden verwoord dat deze aansluiten bij de prioriteiten van andere beleidsterreinen, en indien nodig beleidsoplossingen kan aanpassen om aansluiting te vinden bij het politieke klimaat. Een dergelijke functionaris kan draagvlak creëren binnen een organisatie of samenwerkingsverband om gezondheid anders te 'framen' en meer te verbinden met bijvoorbeeld maatschappelijke participatie $(47,48)$. De positionering en aanwezige competenties van deze functionaris beïnvloeden uiteraard wel de mate van macht, mandaat en middelen die deze functionaris ter beschikking heeft en in het verlengde daarvan de mogelijkheden om op diverse niveaus binnen een organisatie draagvlak te verwerven. In dit kader bevelen wij aan om GGD-professionals op strategisch en tactisch niveau, met voldoende inhoudelijke kennis, senioriteit en autoriteit, te stimuleren meer de rol van beleidsentrepreneur te vervullen.

\subsection{Nadere beschouwing op het uitgevoerde onderzoek}

\section{Beperkingen van het uitgevoerde onderzoek}

Om inzicht te krijgen in het proces dat in iedere gemeente is doorlopen en om praktijkervaringen direct bruikbaar te maken voor andere gemeenten is het begeleidingstraject procesmatig geëvalueerd via actiebegeleidend onderzoek (49-52). Dit soort onderzoek kent twee functies, namelijk het evalueren van de uitgevoerde activiteiten en het mede beïnvloeden van de voortgang van het proces. Het door ons uitgevoerde actiebegeleidende onderzoek kent een aantal beperkingen waardoor de bevindingen voorzichtig geïnterpreteerd moeten worden.

Allereerst vond deelname van de negen gemeenten aan het begeleidingstraject plaats op vrijwillige basis. Gemeenten zijn niet ad random geselecteerd, waardoor mogelijk met name gemeenten die al een positieve houding hebben ten aanzien van integraal gezondheidsbeleid zich voor dit begeleidingstraject hebben aangemeld (selectiebias). Deze betere uitgangspositie binnen begeleidingsgemeenten kan de onderzoeksresultaten hebben beïnvloed. Zo kunnen verbeteringen bovenop de al gunstige startpositie misschien moeilijker te realiseren zijn, waardoor 
een positief effect nauwelijks zichtbaar wordt of pakt de begeleiding ongunstig uit omdat men gedurende het traject pas beseft hoe moeilijk integraal beleid te realiseren is, waardoor een negatief effect ontstaat. Ook de dubbelrol van de onderzoeker bij actiebegeleidend onderzoek kan het proces hebben beïnvloed. Zo maakte de onderzoeker tijdens de intervisiebijeenkomsten problemen in de voortgang van het begeleidingstraject inzichtelijk en bespreekbaar, stimuleerde zij leerprocessen en het geven van feedback $(52,53)$ en diende zij tegelijkertijd objectief te evalueren. Deze verwevenheid van rollen kan de objectiviteit van het onderzoek beïnvloeden. Groot voordeel is echter wel dat de praktijk direct feedback krijgt op haar eigen handelen en dat processen tussentijds bijgesteld kunnen worden. Deze manier van werken heeft juist bij complexe beleidsprocessen zoals het ontwikkelen van integraal gezondheidsbeleid overgewicht meerwaarde, omdat via een lerende ontwerpstrategie het beleid tegelijkertijd wordt ontwikkeld en uitgewerkt (9).

Op basis van de resultaten van de voormeting zijn een beperkt aantal diepte-interviews uitgevoerd bij gemeentelijke afdelingsmanagers met volksgezondheid in hun portefeuille. Dit kleinschalige kwalitatieve onderzoek is een eerste aanzet om zicht te krijgen op de rol van de afdelingsmanagers bij het aansturen van de ontwikkeling van integraal gezondheidsbeleid. Ook dit onderzoek kent duidelijk haar beperkingen. Zo is bijvoorbeeld aan portefeuillehouders of beleidsmedewerkers niet gevraagd hoe zij aankijken tegen de rol van het management bij het ontwikkelen van integraal gezondheidsbeleid. Bovendien zijn de onderzoeksresultaten gebaseerd op zelfrapportage van managers en op een beperkt aantal interviews binnen één specifieke regio van Nederland. Daarom is het moeilijk harde uitspraken te doen en is niet bekend in hoeverre de onderzoeksbevindingen generaliseerbaar zijn naar andere GGD-regio's in Nederland. Deze onderzoeksbevindingen zijn slechts een eerste indicatie van de (on)mogelijkheden van het gemeentelijke management om intersectorale samenwerking en de ontwikkeling van integraal gezondheidsbeleid te stimuleren.

Om de effectiviteit van het begeleidingstraject te bepalen is gewerkt met een voor- en nameting. Er bestaan geen gevalideerde vragenlijsten voor het meten van sectoroverstijgende samenwerking voor integraal beleid, daarom is er een ontwikkeld. Deze vragenlijst bevat belangrijke beemmerende en bevorderende factoren voor intersectorale samenwerking en is gebaseerd op theoretische inzichten en ervaringen uit de praktijk (2). Het lijkt goed mogelijk met behulp van deze vragenlijst een beeld te schetsen van de gemeentelijke intersectorale samenwerking (18), maar er zijn ook enkele kanttekeningen bij het instrument te plaatsen. Een kanttekening is dat de vragenlijst uitgaat van zelfgerapporteerde bevindingen van de respondenten, waardoor het risico op sociaal-wenselijke antwoorden nooit volledig is uit te sluiten. Verder was per gemeente de bereidheid van de beleidsmedewerker VGZ om mailadressen aan te leveren doorslaggevend voor deelname aan het onderzoek, waardoor er sprake kan zijn van een selectiebias van respondenten. Van de 151 niet-VGZ respondenten gaven er 19 aan niet op de hoogte te zijn van het gemeentelijke gezondheidsbeleid. Bovendien snapten zij niet waarom deelname aan het onderzoek werd gevraagd. Zij zien zelf geen raakvlakken tussen integraal gezondheidsbeleid en de eigen werkzaamheden. Dit resulteerde in onbegrip over de onderzoeksvragen. Dit kan er toe hebben geleid dat de validiteit van de vragenlijst voor deze doelgroep respondenten niet optimaal was en we dus niet precies hebben kunnen meten wat we wilden meten. Gedurende het begeleidingstraject zijn logboeken ingevuld. Deze logboeken zijn uitsluitend ingevuld door beleidsmedewerkers VGZ en er is geen informatie verzameld bij portefeuillehouders VGZ en afdelingsmanagers VGZ. Daardoor veronderstellen wij dat er sprake is van onderrapportage met betrekking tot het aantal intersectorale contacten en de geïnvesteerde uren. Ook tussentijdse wisselingen van functies kunnen de uitkomsten van dit onderzoek negatief beïnvloed hebben omdat hiermee veel opgebouwde kennis en vaardigheden als gevolg van het begeleidingstraject verloren zijn gegaan.

\section{Reflectie op het uitgevoerde onderzoek}

Het blijkt lastig te zijn om het ontwikkelingsproces en het resultaat van integraal gezondheidsbeleid wetenschappelijk te onderzoeken, omdat het in principe om een palet van interacties gaat en het begrip moeilijk is te conceptualiseren $(7,8,54)$. Daarom is naast wetenschappelijke kennis ook praktijkkennis over integraal gezondheidsbeleid belangrijk en dienen ervaringen uitgewisseld te worden. Landelijk vervult het Centrum voor Gezond leven (RIVM) deze rol, regionaal is dit een taak voor de GGD. Tot voor kort werd er in Nederland weinig onderzoek gedaan naar (lokaal) integraal gezondheidsbeleid en gemeentelijke intersectorale samenwerking, maar deze situatie is aan het veranderen. Het RIVM heeft in 2010 een studie uitgevoerd onder zestien Nederlandse gemeenten naar intersectoraal samenwerken in de aanpak van gezondheidsachterstanden (30). En vanuit de Academische Werkplaats Tranzo is de afgelopen jaren onderzoek gedaan naar de mogelijkheden om op lokaal niveau een beweegvriendelijke omgeving voor kinderen te stimuleren $(27,55)$ en naar de wijze waarop lokale gezondheidscijfers vertaald worden in het lokale gezondheidsbeleid (26). Een onderzoek waarbij gemeenten vanuit een GGD begeleid werden bij de ontwikkeling van integraal beleid is bij ons weten niet eerder in Nederland uitgevoerd en wetenschappelijk geëvalueerd op proces en resultaat. Met dit exploratieve actiebegeleidende onderzoek is voor het eerst de visie van portefeuillehouders, afdelingsmanagers en beleidsmedewerkers in kaart gebracht op de mogelijkheden om binnen een gemeentelijke organisatie intersectoraal samen te werken. Externe samenwerkingsrelaties van de gemeenten zijn binnen dit onderzoek buiten beschouwing gelaten.

Voor het gemeentelijke begeleidingstraject konden we in 2007 niet terugvallen op 'best-practices' of 'evidence-based' interventies. Aan de hand van een lerende ontwerpstrategie is daarom geprobeerd om samen met gemeenten te zoeken naar innovatieve mogelijkheden om integraal 
beleid te formuleren voor het gezondheidsprobleem overgewicht. Via kleinschalig actiebegeleidend onderzoek is het beleidsproces binnen de gemeentelijke organisatie gevolgd, tussentijds bijgesteld en aangestuurd. In aansluiting op het gehanteerde conceptuele model lag de focus van het gemeentelijke begeleidingstraject op het bevorderen van de verticale samenwerking (binnen het beleidsterrein VGZ) en de horizontale samenwerking (tussen verschillende beleidsterreinen). Op basis van de opgedane ervaringen zouden wij bij herhaling van het onderzoek de focus van het begeleidingstraject waarschijnlijk niet nogmaals leggen op het gezondheidsprobleem overgewicht. Met het thema overgewicht wordt duidelijk dat het om een gezondheidsprobleem gaat waarvoor integraal gezondheidbeleid ontwikkeld moest worden in plaats van integraal beleid. De keuze voor overgewicht heeft relevante aanpalende beleidsterreinen mogelijkerwijs eerder weerhouden van samenwerking dan bevorderd. Thema's zoals meer bewegen, verbeteren van leerprestaties of stimuleren van maatschappelijke participatie zijn in termen van 'framing' dan wellicht passender.

Het accent op de interne gemeentelijke samenwerking heeft gezorgd voor een duidelijke onderzoeksmatige afbakening. Maar in de praktijk werken gemeenten natuurlijk ook vaak samen met externe partners, hetgeen nu volledig buiten beschouwing is gebleven. Achteraf gezien bood het begeleidingstraject gemeenten te weinig houvast om de noodzakelijke intersectorale samenwerking binnen de eigen organisatie zowel bestuurlijk als manageriek aan te sturen. Een dergelijke aansturing is echter wel noodzakelijk omdat verschillende gemeentelijke beleidsterreinen immers niet bewust en vanuit parallelle belangen met elkaar samenwerken.

\section{Toepasbaarheid van het gehanteerde onderzoeksmode}

Binnen dit onderzoek stond de vraag centraal of gemeenten gestimuleerd kunnen worden tot meer intersectorale samenwerking en integrale beleidsontwikkeling. Er zijn in de wetenschappelijke literatuur nauwelijks theoretische perspectieven met betrekking tot deze onderwerpen te vinden (8). Inzicht in de manier waarop binnen een bepaalde organisatie het beleidsproces wordt doorlopen, meer rationeel en volgtijdelijk of meer incrementeel en zoekend naar kansen, vergroot de mogelijkheden om het beleidsproces te beïnvloeden. Ten behoeve van dit onderzoek is daarom een conceptueel model gebruikt om intersectorale samenwerking in beeld te brengen. Dit model meet intersectorale samenwerking op strategisch, tactisch en operationeel niveau binnen een organisatie (2).

Het gebruikte conceptuele model heeft inzichtelijk gemaakt dat GGD en gemeenten uitsluitend een samenwerkingsrelatie hebben op strategisch en operationeel niveau, het gemeentelijke tactisch niveau is niet of nauwelijks betrokken (zie hoofdstuk 2 en 4). Verder maakt het model duidelijk dat inzet en betrokkenheid vanuit alle systeemniveaus noodzakelijk is om te kunnen komen tot integraal gezondheidsbeleid (zie hoofdstuk 3). Zoals in de inleiding is aangegeven is het een ideaal-typisch model waarbij geprobeerd is om via de beleidsmedewerker VGZ de determinanten van het model op verschillende niveaus te beïnvloeden. Daartoe zou de beleidsmedewerker VGZ op eigen initiatief overleg voeren met managers en wethouders. Achteraf gezien lijkt het gehanteerde model te ver af te staan van de dagelijkse praktijk binnen gemeenten. Zo blijkt betrokkenheid vanuit alle drie de niveaus voor gemeentelijke organisaties nog te hoog gegrepen. En het is de vraag of het realistisch is om van beleidsmedewerkers op operationeel niveau te verwachten dat zij in staat zijn om veranderingen in gang te zetten die betrekking hebben op de determinanten op tactisch en strategisch niveau. Dergelijke veranderingen in de organisatiestructuur- en cultuur kunnen niet alleen via een bottom-up benadering worden aangestuurd. Ook is duidelijk geworden dat het bevorderen van intersectorale samenwerking een incrementeel beleidsproces is. Er dient gezocht te worden naar kansen om daadwerkelijk de dialoog aan te gaan met andere beleidsterreinen. Vaak kwamen de onderlinge contacten tussen verschillende beleidsterreinen voort uit persoonlijke betrokkenheid tussen mensen of toevallige kansen ('windows of opportunities').

Het gehanteerde onderzoeksmodel heeft ons geholpen om meer inzicht te krijgen in het verloop van de verticale en horizontale samenwerkingsrelaties binnen gemeenten. Verder onderzoek is gewenst naar de (lokale) mogelijkheden tot intersectorale samenwerking en integrale beleidsontwikkeling, in zijn algemeenheid en specifiek voor complexe gezondheidsproblemen zoals overgewicht. Essentieel in dit kader is om nader te onderzoeken welke mogelijkheden er zijn om gezondheid te verbinden aan andere beleidsterreinen, intern binnen de gemeenten en extern met andere maatschappelijke organisaties. Zodat gezondheid ingezet kan worden als middel om andere meer overkoepelende maatschappelijke vraagstukken aan te pakken.

\section{Academische Werkplaats}

Het beschreven onderzoek is uitgevoerd binnen de Academische Werkplaats Publieke Gezondheid Limburg (56). De wetenschappelijke studies die door deze werkplaats worden verricht hebben een grote maatschappelijke en praktische relevantie (2). De praktijk voedt het onderzoek met vraagstukken en data en de wetenschap draagt methoden aan voor een systematische analyse van het handelen in de praktijk. In de academische werkplaats leren professionals kritisch naar hun eigen handelingen te kijken en wetenschappelijke vragen te formuleren. Wetenschappers daarentegen krijgen de mogelijkheid om toegepast onderzoek te doen. Met het onderzoek beogen we een kritische reflectie te geven op beleid en praktijk en de onderlinge afstemming tussen deze werkprocessen te verbeteren. Gedurende het onderzoek is er een in tensieve samenwerking geweest tussen de onderzoeker, GGD-professionals gezondheidsbevordering, medewerkers van het NIGZ en gemeentelijke beleidsmedewerkers Volksgezondheid. Dit gebeurde voornamelijk via trainingen en intervisiebijeenkomsten. Daarnaast is er meerdere keren contact geweest met portefeuillehouders Volksgezondheid om de voortgang van het be- 
geleidingstraject te bespreken. Op die manier konden veranderingen in de praktijk snel worden gesignaleerd en konden, indien nodig, aanpassingen worden aangebracht in de onderzoeksopzet.

Daarnaast zijn de resultaten van het onderzoek meegenomen in de nieuwe beleidscyclus van gemeenten en GGD om te komen tot een regionale gezondheidsnota 2012-2015. Hierin wil de GGD pro-actiever haar beleidsondersteunende rollen laanjagen, verbinden, regisseren en bewaken) naar gemeenten toe gaan vormgeven en gaat de afdeling gezondheidsbevordering meer beleidsondersteunend werken in plaats van uitsluitend uitvoerend. Door deze intensievere ambtelijke samenwerking tussen GGD en gemeenten hoefde voor dit onderzoek relatief weinig tijd geïnvesteerd te worden in de werving van de gemeentelijke actoren voor deelname aan de verschillende onderdelen van het onderzoek. De uitvoering van het begeleidingstraject werd mede bepaald door de mogelijkheden van de betrokken beleidsmedewerker om binnen de eigen organisatie tijd vrij te maken voor deelname aan het traject. Het onderzoek leverde interessante gegevens op, zowel voor gemeenten (beperkte tactische betrokkenheid), de GGD-professionals (verbreding eigen professionaliteit), als voor het onderzoeksteam (meer instrumenten nodig om integraal gezondheidsbeleid te monitoren en te evalueren). Mede op basis van de resultaten van dit onderzoek wordt er vanuit ZonMw en de Academische Werkplaats Publieke Gezondheid Limburg vervolgonderzoek geïnitieerd.

\section{Implicaties voor beleid, praktijk en onderzoek}

De resultaten van dit onderzoek naar integraal gezondheidsbeleid zijn meegenomen in de nieuwe visie van de GGD Zuid Limburg op Publieke Gezondheid. Gezien de achterblijvende gezondheid in Zuid-Limburg, de vele inwoners met een lage sociaal-economische status (ses) en de structurele bevolkingsdaling, heeft de GGD geconcludeerd dat investeren in een gezonde samenleving hard nodig is. Daarom heeft de GGD Zuid Limburg in 2010 samen met haar gemeenten een nieuwe visie op Publieke Gezondheid ontwikkeld, met als belangrijkste uitgangspunten:

- de individuele preventieve benadering van gezondheidsbevordering is te smal en beperkt om een effectieve gezondheidswinst te kunnen realiseren;

- samenwerking tussen organisaties en een ketengerichte aanpak zijn onontbeerlijk

- aandacht voor gezondheidswinst voor (groepen met) grote gezondheidsachterstand is intensief en moet zowel op individueel niveau als in de leefomgeving plaatsvinden;

- beschikbare publieke middelen zijn begrensd en vragen duidelijke strategische keuzes;

- de rol van de burger, inclusief de eigen verantwoordelijkheid van burgers, dient in deze nieuwe brede visie expliciet te worden meegenomen (34).
Zoals uit de literatuur maar ook uit dit onderzoek blijkt is intersectorale samenwerking, intern binnen een gemeente en regionaal met ketenpartners, belangrijk om meer omgevingsgerich gezondheidsbeleid te kunnen ontwikkelen. Onze onderzoeksaanbeveling 'realiseren van commitment en duidelijk aansturing van het beleidsproces' is in Zuid-Limburg vertaald in één gezamenlijke nota 'Een gezonde koers voor Zuid-Limburg!, regionale nota gezondheidsbeleid Zuid-Limburg 2012-2015' (57) waarin de 18 Zuid-Limburgse gemeenten de publieke gezondheidstaken veel meer gezamenlijk gaan uitwerken en het zoeken van verbindingen tussen verschillende beleidsterreinen een belangrijk beleidsdoel is geworden. De GGD Zuid Limburg heeft in aansluiting op de onderzoeksaanbeveling publieke gezondheidstaken delegeren naar de GGD' haar gemeenten nadrukkelijk ondersteund bij het schrijven van deze nota. Tevens is zowel op strategisch, tactisch als operationeel niveau het regionale beleid afgestemd met gemeenten en een toelichting gegeven tijdens de bespreking van deze nota in alle gemeenteraden en/of raadscommissies.

De resultaten van dit onderzoek zijn gepubliceerd in Nederlandstalige tijdschriften die goed toegankelijk zijn voor GGD'en en gemeenten. Ook zijn bevindingen landelijk besproken in diverse gremia. Er is erkenning voor het feit dat gemeenten en GGD'en op tactisch niveau vrijwel niet samenwerken en het besef groeit dat hier mogelijk een belangrijke sleutel ligt voor verbetering van de lokale intersectorale samenwerking. Een sleutel die uiteraard wel nader op haalbaarheid en effectiviteit dient te worden onderzocht.

\subsection{Realistische uitdaging of utopie?}

\section{De uitdaging}

Waar op landelijk niveau vanuit het ministerie de vormgeving van lokaal integraal gezondheidsbeleid bijna als een vanzelfsprekendheid wordt voorgesteld, blijkt de concrete uitwerking ervan op lokaal niveau een bijzonder lastige opgave te zijn waar veel gemeenten mee worstelen. In feite staat de ontwikkeling van (lokaal) integraal gezondheidsbeleid binnen Nederland nog in de kinderschoenen. Dit roept de vraag op of het stimuleren van de ontwikkeling van integraal gezondheidsbeleid een realistische uitdaging is voor Nederlandse gemeenten of dat hier eerder sprake is van utopie?

Voor veel gezondheidsproblemen, de zogenaamde 'wicked problems', bestaan geen simpele oorzaken of oplossingen. Essentieel in dit kader is om de complexiteit van deze vraagstukken te reduceren. De WHO beveelt in dit kader aan om de besluitvorming te decentraliseren, netwerkvorming te stimuleren, kleinschalige iteratieve interventies uit te voeren en niet te denken vanuit risico's maar in uitdagingen (58). De complexiteit van gezondheidsvraagstukken vraagt expliciet 
van professionals om kennis en kunde met elkaar te delen. Het versterken van de onderlinge samenwerking tussen GGD en gemeenten en het beter benutten van elkaars expertise dient hierbij centraal te staan.

Volksgezondheidsproblemen hebben van oudsher een duidelijke publieke dimensie en dit legitimeert inhoudelijke afstemming en verbinding tussen het beleidsterrein VGZ en andere gemeentelijke beleidsterreinen. Ook in het verleden zijn door beïnvloeding van sociaal-economische, culturele en omgevingsfactoren reeds vele gezondheidssuccessen gerealiseerd. Echter, de afgelopen decennia heeft het accent binnen het vakgebied publieke gezondheid vooral gelegen op het realiseren van gezondheidswinst via leefstijlaanpassingen van burgers. Leefstijladviezen klinken vaak moraliserend en daar zit de burger niet op te wachten. Voor het oplossen van de huidige complexe gezondheidsproblemen is het belangrijk onder ogen te zien dat er meer gezondheidswinst en maatschappelijke legitimiteit gerealiseerd kan worden door aspecten zoals werkgelegenheid, prettig samenleven en maatschappelijke participatie actiever te betrekken bij de zoektocht naar oplossingen. De uitwerking van dergelijke plannen behoeft wel stevige sturing van zowel de landelijke overheid als de lokale overheden omdat de intersectorale samenwerking, die hiervoor noodzakelijk is, niet vanzelf tot stand komt. Zo vermelden bijvoorbeeld gemeentelijke gezondheidsnota's voor de beleidsperiode 2007-2011 wel vaak het belang van een integrale aanpak van overgewicht (59), maar dit wil niet zeggen dat dit onderwerp binnen de gemeentelijke organisatie een hoge beleidsprioriteit krijgt en gemeenten duidelijk zicht hebben hoe zij sturing kunnen geven aan dit beleidsproces. Met daadkrachtige inhoudelijke sturing op managementniveau vanuit de gemeente en inbreng van kennis en kunde vanuit de GGD, kan integraal gezondheidsbeleid wellicht succesvoller dan tot nu toe worden vormgegeven. Gezien de beperkte beleidscapaciteit en de ambtelijke discontinuiteit is het aan te bevelen dat de gemeente de beleidsregie nadrukkelijker in samenwerking met haar GGD uitvoert of als een bestuurlijke opdracht neerlegt bij haar GGD. Een gemeenschappelijke regeling (GR) kan dan een prima instrument zijn om wettelijke beleidsmatige en/of uitvoerende publieke gezondheidstaken te delegeren.

Een GGD kan de ontwikkeling van integraal gezondheidsbeleid inhoudelijk stimuleren maar een gemeente dient intersectorale samenwerking te verankeren binnen de eigen beleidsprocedures. Daarnaast is het raadzaam om nadrukkelijker in de Wpg op te nemen dat de Colleges van B\&W verantwoordelijk zijn voor integraal gezondheidsbeleid. Een wettelijke verplichting tot het ontwikkelen van integraal gezondheidsbeleid heeft mogelijk meer effect dan een vrijwillig trainingstraject. Integraal gezondheidsbeleid wordt door veel gemeenten nu nog vaak gezien wordt als een utopie, maar integrale beleidsontwikkeling is zeker een realistische uitdaging voor gemeenten. Door gezondheid nadrukkelijker te verbinden aan andere maatschappelijke doelstellingen ontstaan er nieuwe mogelijkheden tot intersectorale samenwerking. Wellicht is het in dit licht beter om te spreken over het bevorderen van een integrale beleidsontwikkeling Belangrijk hierbij is om aan te geven dat het een ingewikkeld beleidsproces is waarbij alle beleidssectoren van de gemeente betrokken dienen te zijn en aangemoedigd worden om hun bijdrage aan gezondheid te benoemen en te concretiseren. Centraal dient te staan het gezamenlijk vanuit verschillende beleidsterreinen werken aan oplossingen voor maatschappelijke problemen, waar gezondheid uiteraard een onderdeel van is maar niet het enige uitgangspunt is van het gemeentelijke beleid.

De GGD Zuid Limburg is in 2007 de uitdaging aangegaan om haar gemeenten te begeleiden bij het ontwikkelen van integraal beleid. Dit was zeker geen gemakkelijk begeleidingstraject, maar heeft wel veel bruikbare informatie opgeleverd voor beleid, praktijk en onderzoek. Wij dagen andere GGD'en en gemeenten uit om vergelijkbare samenwerkingsprojecten met elkaar aan te gaan en op zoek te gaan naar innovatieve oplossingen voor complexe maatschappelijke problemen. 


\subsection{Resumé}

De belangrijkste aanbevelingen die wij op grond van dit onderzoek doen zijn:

- Om intersectorale samenwerking binnen gemeenten te realiseren is commitment en duidelijke aansturing op zowel bestuurlijk als managementniveau intern binnen de eigen organisatie en in samenwerking met externe organisaties noodzakelijk. Daarom bevelen wij aan:

- de functionele verantwoordelijkheid voor het stimuleren van intersectorale samenwerking binnen gemeenten explicieter te benoemen;

- helder te formuleren in missie of prioriteitennota wat er moet gebeuren en meer te investeren in het proces hoe het beleid geïmplementeerd kan worden;

- integrale gezondheidsdoelen op te nemen in gemeentelijke programma- en begrotingsdocumenten;

- tactisch overleg tussen gemeente, GGD en externe samenwerkingspartners te initiëren; - in de Wpg nadrukkelijker op te nemen dat het College van B\&W verantwoordelijk is voor het ontwikkelen en aansturen van integraal (gezondheids)beleid.

- De meerwaarde van intersectorale samenwerking voor het ontwikkelen van integraal (gezondheids)beleid is onvoldoende bekend binnen gemeenten. 'Best-practices' zijn belangrijk om gemeenten te kunnen overtuigen van deze meerwaarde. Daarom bevelen wij aan:

- publieke gezondheid meer te bevorderen vanuit overkoepelende beleidsthema's en gezondheid niet als primair doel te benoemen, maar als middel;

- gemeenten te stimuleren innovatieve intersectorale interventies te ontwikkelen en te begeleiden met praktijkgericht evaluatieonderzoek;

- vanuit Academische Werkplaatsen meer onderzoek te doen naar de effectiviteit van een integrale aanpak van maatschappelijke problemen en de verbinding met publieke gezondheidsproblemen.

- Door de beperkte beleidscapaciteit voor publieke gezondheid en door ambtelijke discontinuïteit worden de verschillende beleidsrollen binnen gemeenten niet adequaat vervuld. Gemeenten kunnen hun wettelijke regiefunctie voor publieke gezondheidstaken delegeren naar de GGD. Daarom bevelen wij aan:

- beleidsrollen van aanjager, adviseur, regisseur, makelaar en bewaker zowel vanuit lokaal bestuur als verlengd lokaal bestuur, dus gemeente en respectievelijk GGD, te laten uitvoeren en hier bestuurlijk en manageriek duidelijke afspraken over te maken;

- kennis en kunde veel meer te delen tussen GGD en gemeente, hier is behoefte aan mede in het licht van de beperkt beschikbare gemeentelijke beleidscapaciteit en de ambtelijke discontinuïteit;
- dat gemeenten de wettelijke beleidsmatige en/of uitvoerende publieke gezondheidstaken nadrukkelijker in samenwerking met haar GGD uitvoeren óf als een bestuurlijke opdracht delegeren naar haar GGD.

- Een GGD kan (on)gevraagd advies uitbrengen aan gemeenten in aansluiting op maatschappelijke vraagstukken die een hoge politieke prioriteit. Dit betekent samen met gemeenten zoeken naar vernieuwende inzichten en oplossingen. Hiervoor dienen de competenties van de GGD beleidsmedewerker te worden versterkt. Daarom bevelen wij aan:

- de inhoudelijke focus meer te leggen op omgevings- en sociale determinanten van gezondheidsproblemen;

- de GGD-manager meer de rol van beleidsentrepreneur te laten vervullen en het gemeentelijke lijnmanagement (tactische niveau) nadrukkelijker te betrekken bij het ontwikkelen van integraal (gezondheids)beleid;

- meer tijd in te ruimen voor het proces van beleidsontwikkeling, het gezamenlijk zoeken naar oplossingen en het verbinden van bestaand beleid aan nieuw beleid.

- Het begrip integraal gezondheidsbeleid dient anders te worden 'geframed' en gezondheid dient meer vanuit integraliteit te worden benaderd. Gezondheidsproblemen worden inhoudelijk zelden vertaald in termen van verlies van arbeidsproductiviteit of onvolwaardige maatschappelijke participatie. Daarom bevelen wij aan:

- meer te kijken naar de mogelijkheden om vanuit publieke gezondheid een bijdrage te leveren aan het oplossen van maatschappelijke problemen,

- te erkennen dat gezondheid niet een primair doel hoeft te zijn, maar een middel om andere meer overkoepelende gemeentelijke doelen te realiseren,

- voortaan te spreken in termen van integraal beleid in plaats van integraal gezondheidsbeleid. 


\subsection{Literatuur}

1. Jackson SF, Perkins F, Khandor E, Cordwell L, Hamann S, Buasai S. Integrated health promotion strategies: a contribution to tackling current and future health challenges. Health Promotion International 2007;21(S1):75-83.

2. Jansen M. Mind the gap: collaboration between practice, policy and research in local public health. Maastricht: University Maastricht; 2007.

3. Pagliccia N, Spiegel J, Alegret M, Bonet M, Martinez B, Yassi A. Network analysis as a tool to assess the intersectoral management of health determinants at the local level: A report from an exploratory study of two Cuban municipalities. Social Science \& Medicine 2010; 71:394-9.

4. Michie S, van Stralen MM, West R. The behavior change wheel: A new method for characterising and designing behavior change interventions. Implementation Science 2011;6(1):42-53.

5. van Assema P, Steenbakkers M, Rademaker C, Brug J. The impact of a nutrition education intervention on main meal quality and fruit intake in people with financial problems. Journal of Human Nutrition and Dietetics 2005 Jun;18(3):205-12.

6. Maas J, Storm I. Integraal gezondheidsbeleid op nationaal niveau. Wat kunnen we leren van de ervaringen uit andere landen? Bilthoven: RIVM briefrapport 2701610052011.

7. Storm I, Verweij A, Van der Lucht F. Integraal gezondheidsbeleid op lokaal niveau. Wat weten we en hoe nu verder? [Local integrated health policy. What do we know and how to proceed?]. Bilthoven: RIVM briefrapport 2701610042011.

8. Harting J, Paauwe L, Stronks K. Theoretische perspectieven op intersectorale samenwerking en integraal beleid. Een thematische review.: AMC Sociale Geneeskunde, september 2011.

9. van Heffen 0, Kerkhoff AHM. Beleidsvoering in de algemene gezondheidszorg. Assen: Van Gorcum; 1997.

10. RVZ, Onderwijsraad, Rob. Buiten de gebaande paden. Advies over intersectoraal gezondheidsbeleid, advies uitgebracht door de Raad voor de Volksgezondheid en Zorg, de Onderwijsraad en de Raad voor het openbaar bestuur. Zoetermeer 2009.

11. RVZ. Buiten de gebaande paden. Inspirerende voorbeelden van intersectoraal gezondheidsbeleid. Zoetermeer 2009.

12. St-Pierre L. Governance tools and framework for Health in All Policies. Québec: National Collaborating centre for Healthy Public Policy. European Observatory on Health Systems and Policies. 2010

13. Gouverneur M. De invloed van verschillende factoren op integrale samenwerking binnen Nederlandse gemeenten. Utrecht: Universiteit Utrecht Movisie 201130 juni.
14. Matland RE. Synthesizing the Implementation Literature: The Ambiguity-conflict Model of Policy Implementation. Journal of Public Administration Research and Theory 1995;5(2):145-74.

15. Warner M, Gould N. Integrating health in all policies at the local level: using network governance to create 'Virtual Reorganization by Design'. In: Kickbusch I, editor. Policy Innovation for Health. New York: Springer; 2009. p. 125-63.

16. de Leeuw E, McNess A, Stagnitti K, Crisp B. It's research, Jim, but not as we know it. Acting at the Nexus. Integration of Research, Policy and Practice. Geelong: Deakin University 2007.

17. Stadlander M. Relaties GGD - gemeenten: BMC advies management 2011.

18. Steenbakkers $M$, Jansen M, Maarse $H$, de Vries $N$. Lokaal integraal gezondheidsbeleid intersectorale samenwerking vanuit het perspectief van gemeenten. Tijdschrift voor gezondheidswetenschappen 2010;88(3):136-43.

19. Hoeijmakers M. Local health policy development processes. Health promotion and network perspectives on local health policy-making in the Netherlands. Maastricht: University Maastricht; 2005.

20. Ruland E. Bestuurlijke verankering van innovaties in de openbare gezondheidszorg: lessen uit de casus Hartslag Limburg. Maastricht: Universiteit Maastricht; 2008.

21. Rütten A, Röger U, Abu-Omar K, Frahsa A. Assessment of organizational readiness for health promotion policy implementation: test of a theoretical model. Health Promotion International 2009;24(3):243-51.

22. Maarse JAM. Sturing op gezondheidsdoeleinden en gezondheidswinst op macroniveau. Achtergrondstudie bij RVZ-rapport: Sturen op gezondheid. [Directing on health targets and health improvement on macro level. A background study by RVZ. Control on health.]. In: RVZ, editor.2011

23. Mannheimer LN, Lehto J, östlin P. Window of opportunity for intersectoral health policy in Sweden-open, half-open or half-shut? Health Promotion International 2007;22(4):307-15.

24. Derksen W, Schaap L. Lokaal bestuur [Local government]. 5e druk ed: Elsevier; 2007.

25. Lamberts PHG, Steenbakkers M, Thijssen NHB, Bacus-Mujakovic S, de Vreede JJM, Hajema KJ, et al. Een gezonde kijk op Zuid-Limburg. Regionale Volksgezondheid Toekomst Verkenning 2010. Geleen: GGD Zuid Limburg 2010.

26. De Goede J. Knowledge in process. Tilburg: Tilburg University; 2011.

27. Aarts M-J, Jeurissen MPJ, van Oers H, Schuit AJ, van de Goor IAM. Multi-sector policy action to create activity-friendly environments for children: a multiple-case study. Health Policy 2011;101:11-9.

28. Larsen M, Koudenburg OA, Gulis G. Challenges and facilitators for intersectoral health policy in a Danish municipality. European Journal of Public Health 2011;21(Supplement 
29. CGL. I-database. Bilthoven: RIVM; 2010.

30. Storm I, Savelkoul M, Busch MCM, Maas J, Schuit AJ. Intersectoraal samenwerken in de aanpak van gezondheidsachterstanden. Een onderzoek onder zestien gemeenten in Nederland. Bilthoven: RIVM 2010

31. Ministerie van Volksgezondheid, Welzijn en Sport. Wet Publieke Gezondheid, wet van 9 oktober 2008, houdende bepalingen over de zorg voor de publieke gezondheid. [Law on Public Health], (2008).

32. Inspectie voor de Gezondheidszorg. Staat van de gezondheidszorg 2005, deelrapport. De gemeenten zijn veel meer betrokken bij de openbare gezondheidszorg, ze moeten nu meer zelf uitvoeren. Resultaten van het toezicht op de gemeentelijke betrokkenheid 2004. Den Haag: IGZ 2005

33. Smeets K, Kornalijnslijper N. Gemeenten en kwalitietsverbetering in de openbare gezondheidszorg. Resultaten nulmeting bestuurlijke benchmark 2006. VGN-project 'beter voorkomen'. Den Haag: SGBO 2006.

34. GGD, Limburg Z. Naar een duurzaam gezonder Zuid-Limburg. Een nieuwe benadering van de gezondheid van mensen. Geleen: GGD Zuid Limburg 2010.

35. Inspectie voor de Gezondheidszorg. Concept resultaten thematisch toezicht integraal beleid. [Concept results thematic inspection on integrated policy.]. 2008

36. Inspectie, Gezondheidszorg livd. Staat van de gezondheidszorg 2010. Meer effect mogelijk van publieke gezondheidszorg. (Health status 2010. More effect possible in public health.] Utrecht: Ministerie VWS; 2010

37. Fafard P. Evidence and Healthy Public Policy: Insights from Health and Political Sciences. Ottawa: National Collaborating Centre for Healthy Public Policy May 2008

38. de Bruijn H. Framing, over de macht van taal in de politiek: Atlas; 2011.

39. Chong D, Druckman JN. Framing Theory. Annu Rev Polit Sci 2007;10:103-26.

40. Wikipedia. Framing (social sciences). 2012 [updated maart 2012]; http://en.wikipedia.org/ wiki/Framing_(socialsciences)].

41. van der Lucht F, Polder J. Van gezond naar beter. Kernrapport Volksgezondheid Toekoms Verkenning 2010 [Dutch Public Health Status and Forecasts Report 2010]. Bilthoven: Rijksinstituut voor Volksgezondheid en Milieu 2010.

42. Huber M, Knottnerus JA, Green L, al e. How should we define health? BMJ 2011;343 (d4163).

43. McCombs M. Explores and Surveyors: Expanding strategies for agenda-setting research. Journalism Quarterly 1992;69(4):813-24.

44. Kingdon JW. Agendas, alternatives and public policies. New York: Addison-Wesley Educational Publishers Inc.; 2003.

45. Hoeijmakers M, de Leeuw E, Kenis PN, de Vries NK. Lokaal gezondheidsbeleid: een beleidsentrepreneur voor integraal beleid. Tijdschrift voor gezondheidswetenschappen 2007;85(1):43-6
46. Harting J, Kunst AE, Kwan A, Stronks K. A 'health broker' role as a catalyst of change to promote health: an experiment in deprived Dutch neighbourhoods. Health Promotion International Advance Access 2010(November 10):1-17.

47. Catford J. Editorial. Social entrepreneurs are vital for health promotion-but they need supportive environments too. Health Promotion International 1998;13(2):95-8.

48. Hoeijmakers $M$, de Leeuw E, Kenis $P$, de Vries NK. Local Health policy develpment processes in the Netherlands: an expanded toolbox for health promotion. Health Promotion International 2007:22(2):112-21.

49. Koelen MA, van den Ban W. Health education and Health promotion. Wageningen: Academic Publishers; 2004.

50. Saan H, de Haes W. Gezond effect bevorderen: het organiseren van effectieve gezondheids bevordering. Woerden: NIGZ; 2005.

51. Boeije H. Analyseren in kwalitatief onderzoek. Denken en doen. Den Haag: Boom onderwijs; 2006.

52. Wagemakers MAE. Actiebegeleidend onderzoek ter bevordering van intersectorale samenwerking en bewonersparticipatie. Deervaringenmethetwijkgerichtgezondheidswerk in Eindhoven. Tijdschrift voor gezondheidswetenschappen 2007;85(1):23-31.

53. DiClemente CC, Marineilli AS, Singh M, Bellino LE. The Role of Feedback in the Process of Health Behavior Change. Am J Health Behav 2001;25:217-27.

54. Barr V, Pedersen S, Pennock M, Rootman I. Health equity through intersectoral action: an analysis of 18 country case studies. WHO: Public Health agency of Canada 2008

55. Aarts M-J. Children, physical activity and the environment: opportunities for multi-sector policy. Tilburg: Tilburg University 2011

56. GGD Zuid Limburg, Universiteit Maastricht. Academische Werkplaats Publieke Gezondheid Limburg (AW). Maastricht 2006

57. Steenbakkers M, Lamberts PHG, Thijssen NHB. Een gezonde koers voor Zuid-Limburg Regionale nota gezondheidsbeleid Zuid-Limburg 2012-2015: Zuid-Limburgse gemeenten, 1 juli 2011.

58. WHO. Governance for health in the 21st century: a study conducted for the WHO Regional Office for Europe. Baku, Azerbaijan: World Health Organization Europe 12-15 september 2011

59. Zuid-Limburgse gemeenten. Samen gezond! Regionale prioriteiten Volksgezondheidsbeleid Zuid Limburg 2007-2011 [Together healthy! Regional Public Health Policy in South Limburg 2007-2011]. Maastricht 2007. 


\section{Samenvatting}

Summary

Dankwoord

Curriculum Vitae

\section{Overzicht publicaties}




\section{Samenvatting}

Gemeenten zijn vanuit de Wet publieke gezondheid verantwoordelijk voor de volksgezondheid van hun burgers. Het ministerie van VWS benadrukt het belang van integraal gezondheidsbeleid, ook wel 'Health in All Policies' genoemd, en stimuleert gemeenten om lokaal integraal gezondheidsbeleid te ontwikkelen. Men spreekt van integraal gezondheidsbeleid, wanneer sectoren binnen en buiten het volksgezondheidsdomein samenwerken om gezondheidsschade te voorkómen en/of gezondheid te bevorderen. Intersectorale samenwerking wordt gezien als een voorwaardenscheppend proces om te komen tot formulering van integraal beleid. Echter, lokaal worden nog weinig initiatieven ondernomen tot intersectorale samenwerking. In feite staat de ontwikkeling van integraal gezondheidsbeleid in Nederland nog in de kinderschoenen.

Gemeenten vervullen een regiefunctie bij het ontwikkelen van integraal gezondheidsbeleid en het stimuleren van intersectorale samenwerking. Samenwerking niet alleen met externe partners, maar juist ook intern binnen een gemeente tussen verschillende beleidssectoren. De vraag is echter welke mogelijkheden gemeentelijke overheden hebben om de publieke gezondheid te bevorderen, om verbindingen te leggen tussen allerlei sectoren die invloed hebben op gezondheid? Dit proefschrift richt zich op de mogelijkheden om intern binnen de eigen gemeentelijke organisatie te werken aan samenhangend gezondheidsbeleid, in zijn algemeenheid en specifiek voor het gezondheidsprobleem overgewicht. De volgende onderzoeksvraag staat hierbij centraal:

Kunnen gemeenten gestimuleerd worden tot meer intersectorale samenwerking en integrale beleidsontwikkeling voor het gezondheidsprobleem overgewicht?

In de verschillende hoofdstukken zijn deelvragen van het onderzoek centraal gesteld en beantwoord. Om verschillende hoofdstukken van dit proefschrift goed te kunnen plaatsen wordt in het inleidende hoofdstuk eerst het kader geschetst waarbinnen het onderzoek heeft plaatsgevonden. Er wordt stil gestaan bij de definitie van integraal gezondheidsbeleid, de wettelijke grondslag van het gemeentelijke gezondheidsbeleid en het belang van gemeentelijke intersectorale samenwerking. Vervolgens wordt ingegaan op de focus van dit onderzoek, het gebruikte conceptuele model en de methoden van onderzoek. De verschillende hoofdstukken van dit proefschrift beschrijven de onderzoeksresultaten van de deelvragen die binnen dit onderzoek zijn geformuleerd. Hieronder volgt een korte samenvatting van de afzonderlijke hoofdstukken.

In Hoofdstuk 1 wordt aangegeven dat lokale overheden via intersectorale samenwerking veel gezondheidswinst kunnen realiseren, maar dat gemeentelijke beleidsafdelingen inclusief de GGD als verlengd lokaal bestuur niet vanzelfsprekend samenwerken. Afstemming van beleid tussen verschillende beleidssectoren kan in gang worden gezet door actoren op strategisch tactisch en operationeel niveau met elkaar in overleg te laten treden. Binnen dit proefschrift is het accent gelegd op het bevorderen van intersectorale samenwerking binnen gemeenten en de ondersteuningsmogelijkheden van een GGD bij het ontwikkelen van lokaal integraal gezondheidsbeleid voor het gezondheidsprobleem overgewicht.

In hoofdstuk 2 wordt aangegeven hoe gemeenten zelf aankijken tegen het ontwikkelen van integraal gezondheidsbeleid en de eigen mogelijkheden om intersectoraal samen te werken Portefeuillehouders, afdelingshoofden/managers en beleidsmedewerkers zijn via een digitale vragenlijst hierover bevraagd (voormeting). Uit de onderzoeksresultaten blijkt dat binnen de gemeentelijke organisatie de afdelingshoofden het minst positief zijn over integraal gezondheidsbeleid. Vaak ontbreekt op dit tactische niveau de samenwerking met andere beleidsterreinen en is er minder draagvlak voor integraal beleid binnen het eigen beleidsterrein. Vooral op het niveau van de portefeuillehouder en beleidsmedewerker blijken verbindingen te worden gelegd met andere beleidsterreinen. De casus overgewicht maakt duidelijk dat de verschillende gemeentelijke beleidsterreinen niet bewust en vanuit parallelle belangen intersectoraal samenwerken. Geconcludeerd wordt dat over de invloed van afdelingshoofden op de onderlinge samenwerking veel onduidelijkheid bestaat en dat intersectorale samenwerking rondom het gezondheidsprobleem overgewicht beperkt ontwikkeld is binnen gemeenten.

Hoofdstuk 3 beschrijft een begeleidingstraject dat de GGD Zuid Limburg en het NIGZ in negen Zuid-Limburgse gemeenten hebben uitgevoerd om gemeenten te helpen bij het ontwikkelen van integraal gezondheidsbeleid overgewicht. Via actiebegeleidend onderzoek is het begeleidingstraject gedurende drie jaar procesmatig geëvalueerd. Uit het onderzoek blijkt dat integraal beleid gemeentelijke bestuurders en ambtenaren wel aanspreekt, maar dat slechts weinig gemeenten erin slagen om intersectorale samenwerking tussen beleidssectoren te realiseren Belangrijke knelpunten zijn onvoldoende kennis en competenties én bestuurlijke en ambtelijke continuiteit. Daar komt bij dat in de samenwerking tussen GGD en gemeenten een gerichte sturing op managementniveau ontbreekt. Een lange termijn perspectief en een doelgerichte aanpak met vooraf geformuleerde einddoelen zijn gewenst. Aanbevolen wordt om het gemeentelijke managementniveau VGZ actiever te betrekken bij de ontwikkeling van integraal beleid en de dialoog tussen de diverse beleidssectoren (VGZ en niet-VGZ) blijvend te stimuleren. Competentieverbeteringen bij en duidelijke samenwerkingsafspraken tussen GGD en gemeenten zijn hiervoor essentieel.

In hoofdstuk $\mathbf{4}$ wordt de rol van de gemeentelijke manager nader bekeken. Uit de resultaten van de voormeting blijkt dat het tactische niveau niet of nauwelijks betrokken is bij intersectorale samenwerking. Via diepte-interviews met 13 gemeentelijke managers VGZ is de rol van 
afdelingsmanagers VGZ binnen het gemeentelijke beleidsproces geëxploreerd. De resultaten van dit onderzoek laten zien dat de afdelingsmanagers VGZ niet afwijzend staan tegenover intersectorale samenwerking binnen hun gemeente en het formuleren van integraal gezondheidsbeleid. Zij voelen zich vooral hiërarchisch verantwoordelijk voor volksgezondheid. De inhoudelijke betrokkenheid is in de praktijk echter zeer beperkt en gedelegeerd. Gemeentelijke managers vragen aan de GGD haar expertise op het vlak van intersectorale samenwerking en integraal beleid explicieter kenbaar te maken. Zonder gerichte inhoudelijke sturing is het moeilijk gezondheid structureel een plek te geven binnen andere beleidssectoren. Als verlengd lokaal bestuur ligt hier een uitdaging voor de GGD om dit beleidsproces inhoudelijk te voeden. De GGD wordt door de respondenten aangeraden veel actiever op te treden in het (on)gevraagd adviseren van het gemeentelijke lijnmanagement. De zeer beperkte beschikbare beleidscapaciteit binnen gemeenten voor gezondheid versterkt de noodzaak tot gerichte beleidsondersteuning vanuit de GGD.

In hoofdstuk $\mathbf{5}$ worden de effecten van beleidsondersteuning op de ontwikkeling van gemeentelijke intersectorale samenwerking en integraal beleid beschreven. De resultaten van de voormeting zijn hiervoor vergeleken met die van de nameting. Uit dit onderzoek blijkt dat de effecten van het begeleidingstraject in het algemeen zeer beperkt zijn, zowel in positieve als negatieve zin. Het begeleidingstraject heeft positief bijgedragen aan de vormgeving van integraal beleid voor het gezondheidsprobleem overgewicht. Met name de betrokken beleidsmedewerkers VGZ zijn positief beïnvloed door het traject; hun kennis en kunde is toegenomen maar ook het bese dat het realiseren van intersectorale samenwerking binnen een gemeentelijke organisatie geen gemakkelijk proces is. Zeker als binnen de eigen gemeente bestuurders en managers niet of beperkt betrokken zijn. Geconcludeerd wordt dat het stimuleren van intersectorale samenwerking rondom gezondheidsproblemen betrokkenheid en inzet vereist vanuit álle hiërarchische niveaus binnen een gemeente. Ook dient er meer overleg plaats te vinden met niet-VGZ beleidssectoren. Met daadkrachtige sturing op managementniveau vanuit de gemeente en meer inbreng van kennis en kunde vanuit de GGD, kan integraal beleid wellicht succesvoller dan tot nu toe worden vormgegeven.

In hoofdstuk 6 worden alle resultaten van de door ons uitgevoerde onderzoeken met elkaar verbonden. De resultaten van de voor- en nameting, de bevindingen uit de procesevaluatie van het begeleidingstraject en de diepte interviews met de gemeentelijke afdelingsmanagers VGZ. De resultaten laten zien dat meer inzet en betrokkenheid vanuit elk hiërarchisch niveau binnen de gemeente de ontwikkeling van integraal gezondheidsbeleid kan stimuleren. Hiervoor dient het gemeentelijke managementniveau nadrukkelijker betrokken te worden in het beleidsproces en dient de GGD haar competenties te verbreden.
Tenslotte wordt in hoofdstuk $\mathbf{7}$ een reflectie gegeven op de beschreven onderzoeksresultaten Vervolgens worden aanbevelingen gedaan voor praktijk, beleid en onderzoek en wordt er bedis cussieerd of integraal gezondheidsbeleid voor gemeenten een realistische uitdaging is of mee neigt naar utopie. In dit kader wordt ingegaan op het belang van commitment en duidelijke aansturing van intersectorale samenwerking, het feit dat de meerwaarde van deze samenwerking onvoldoende bekend is binnen gemeenten, de beperkte gemeentelijke beleidscapaciteit voor publieke gezondheid en de beperkte competenties van de GGD-professionals. Tevens wordt aangegeven dat het raadzaam is om nadrukkelijker in de Wpg op te nemen dat he College van B\&W verantwoordelijk is voor integraal gezondheidsbeleid en dat het beter is om in de toekomst te spreken over integrale beleidsontwikkeling in plaats van het ontwikkelen van integraal gezondheidsbeleid.

Waar op landelijk niveau vanuit het ministerie de vormgeving van lokaal integraal gezondheidsbeleid bijna als een vanzelfsprekendheid wordt voorgesteld, blijkt de concrete uitwerking ervan op lokaal niveau een bijzonder lastige opgave te zijn waar veel gemeenten mee worstelen Duidelijk is geworden dat integrale beleidsontwikkeling vraagt om bestuurlijke aandacht van het voltallige College, ruimte in het beleidsproces en competente GGD-professionals. Hier ligt een uitdaging voor gemeenten en hun GGD. 


\section{Summary}

The Dutch government encourages municipal authorities to develop 'Health in All Policies' (HiAPs). A policy is called a HiAP when sectors both within and outside the public health domain work together to reduce health damage and to promote health. The development of such a policy requires inter-sectoral collaboration, but municipalities are showing little initiative in this regard. Although municipal governments have a leading function in developing HiAPs and stimulating inter-sectoral collaboration, the HiAP approach still appears to be in its infancy.

Collaboration should not involve only external partners; collaboration with internal departments within the municipal government is at least as important. The question arose how municipa governments perceive the opportunities to set up inter-sectoral collaboration to influence public health? The opportunities to develop HiAPs within a municipality, both in general and specifically to tackle the health problem of obesity, form the central theme of this thesis, which centers on the following general research question:

"Can municipal governments be stimulated to set up more inter-sectoral collaboration and to develop HiAPs for the health problem of obesity?"

The various chapters of this thesis provide answers to specific questions derived from this general research question. The Introduction (Chapter 1) outlines the context within which the studies were carried out. It offers a definition of HiAP, describes the national legislation on public health, the importance of inter-sectoral collaboration, the conceptual framework used and the research methods applied. Chapters 2 to 5 present the results of the research to answer four specific research questions. Chapter 6 presents an overall view of the various research findings. The General Discussion (Chapter 7) reflects on the findings of the various studies. The content of each of the chapters is summarized below.

Chapter 1 starts by describing that municipalities can achieve a great deal of of health profit, but that collaboration between the various departments within municipal governments and thei associated Regional Public Health Services (GGDs) is not a matter of course. The development of HiAPs requires inter-sectoral collaboration at the strategic, tactical (managerial) and operational levels, so that fine-tuning of policies from different sectors can be achieved. The studies reported on in this thesis focused on setting up inter-sectoral collaboration within municipal government as an organization. The studies also looked at the opportunities that GGDs, operating in an advisory role, have to support municipal governments in developing HiAPs. A coaching program for municipal stakeholders was developed and implemented, using obesity as an example.
Chapter 2 answers the question how Dutch municipal governments perceive their opportunities to set up inter-sectoral collaboration. To determine the effectiveness of the coaching program, civil servants, managers and members of the municipal executive (aldermen) were invited to fill in an internet questionnaire prior to and at the completion of the coaching program. The results of the baseline measurement showed a consistent pattern. Municipalities that had agreed to participate in a coaching program saw more opportunities for inter-sectoral collaboration than those not participating in such a program. Within the municipal government, it was the managers who were the least positive about the opportunities for HiAPs. Collaboration with other policy sectors was often lacking at the tactical level of local government,and links to other policy sectors were mainly established at the level of civil servants and municipal councilors. The obesity case clearly demonstrated the lack of inter-sectoral collaboration. We conclude that there is a great lack of clarity on the influence of managers, and that inter-sectoral collaboration to tackle obesity within municipal governments still often remains limited.

Chapter 3 reports on local support for the development of HiAPs. In the Southern Limburg region of the Netherlands, municipal governments prioritized HiAPs targeting obesity in their regional policy statement (2007-2011). Operating in an advisory role, the GGD for Southern Limburg and the National Institute of Health Promotion and Disease Prevention (NIGZ) have supported nine municipalities in South-Limburg, offering both administrative and professional assistance in setting up inter-sectoral collaboration. Emphasis was placed on the first stages of the policy process, viz. policy preparation and policy formulation. A log-book was used to record all activities in the municipalities taking part in the coaching scheme. Outcomes were rated depending on the stage of HiAP proposals. Evaluation of the coaching process demonstrated that the municipalities were positive about the concept of HiAP, but that developing such policies by means of inter-sectoral collaboration is difficult to achieve. Important impediments to this are insufficient knowledge, competencies and administrative and professional continuity. A further problem is the absence of managerial focus and guidance in the relationship between the GGD and municipal authorities. A long-term perspective and a targeted approach with clear goals are needed. We recommend further promotion of more active municipal managerial involvement in the development of HiAPs, as well as consultation between the various policy departments and the GGD. Improvement in terms of competencies and clear collaborative agreements between municipalities and the GGD are essential.

Chapter 4 outlines the role of municipal department managers in achieving HiAPs. Previous research had shown that municipal department managers (i.e. the tactical level) are rarely involved in inter-sectoral collaboration. We used a qualitative interview study to examine the role of municipal managers as regards inter-sectoral collaboration and HiAPs. The results showed that departmental managers did realize that HiAPs require organizational change, but 
emphasized that this is difficult to accomplish. Although they manage their department, they are not involved in the actual content of the policy process. Inter-sectoral collaboration and integrated health policy can be promoted by greater managerial involvement in policy content. The department managers recommended that the GGD should be more active in making municipalities aware of its expertise in the area of inter-sectoral collaboration and integrated health policy. It is a challenge to GGDs to support municipalities in the development of HiAPs. We recommend that GGDs become more proactive in advising municipal department managers. The very limited policy capacity for health-related issues within municipal governments, an average of $0.38 \mathrm{FTE}$, makes this essential.

Chapter $\mathbf{5}$ describes the effects of the coaching program on the development of municipal intersectoral collaboration and HiAPs. Prior to and at the completion of the coaching program, civil servants, heads of departments and aldermen were invited to fill in an internet questionnaire on inter-sectoral collaboration and HiAPs. The results show that the effects of the coaching program were generally very limited and unclear. Nevertheless, the coaching program has made a positive contribution to the development of a HiAP targeting obesity. It was particularly the involvement of civil servants which was favorably influenced by the support. Their knowledge and expertise had increased, as had the awareness that inter-sectoral collaboration within municipal organizations is not an easy process, especially if there is little or no involvement on the part of managers and members of the municipal executive (aldermen). Stimulating inter-sectoral collaboration in relation to specific health problems requires institutional involvement at al levels, from strategic to tactical to operational, and not only within the health policy sector, but with other policy sectors as well. If there is decisive steering by a municipal policy entrepreneur at managerial level, combined with the knowledge and expertise of a 'health broker' from the GGD, HiAPs can perhaps be more successful than has been the case to date.

Chapter $\mathbf{6}$ brings all the different research findings of this thesis together. Based on our action research study in Dutch municipalities, it concludes that developing HiAPs is a challenge. Six of the nine municipalities taking part in the coaching program produced concrete outcomes in terms of HiAP proposals. The results show that more support and involvement at all system levels stimulates the development of HiAPs. The program contributed to the implementation of HiAP interventions targeting obesity. Whereas the pretest findings for municipalities taking part in the coaching program were better than those for non-coached municipalities, this favorable baseline position had faded after 30 months of coaching, although the civil servants in the muncipalities taking part did develop a more positive attitude. We recommend that municipal management become more involved in the development of HiAPs and advise the GGDs to expand their comptencies in this regard. This presents challenges for municipalities as well as the associated GGDs.
The thesis ends with the General Discussion chapter 7, which summarizes the main findings and puts them in a wider context. The chapter concludes with recommendations for practice, policy and research. It discusses whether HiAP is a realistic option for municipal governments or utopia. It comments on the importance of commitment and of managing inter-sectoral collaboration, on the lack of knowledge about HiAP within municipal governments, on the very limited policy capacity for health-related issues available within municipalities and the need to improve the competencies of GGD professionals. Obliging municipal governments by law to take on the responsibility for the development of HiAPs is an option that could be discussed, but it will not be the definitive solution. It would be better to try and frame the health issues in a different way, in terms of the effect of lifestyle on children's academic performance in school or on loss of labor productivity, so as to ensure that other policy domains become interested. Even then, collaboration with other policy sectors will be a matter of individual attitudes.

The Dutch government encourages municipalities to develop HiAPs, which may seem an obvious task, but for municipal governments the HiAP approach is a very difficult task, one with which many municipalities are struggling. HiAP asks for more strategic guidance, more capacity in the policy process and improved competencies among professionals. Here lies a challenge for municipal governments as well as the associated GGDs 


\section{Dankwoord}

Professionals zouden hun werk meer moeten inrichten als een-leven-lang-leren

Ik was net 43 jaar toen ik vijf jaar geleden begon aan dit promotietraject, een traject waar ik als oudgediende binnen de GGD Zuid Limburg enerzijds enorm tegen opzag, maar dat ik anderzijds ook een geweldige uitdaging vond. De Academische Werkplaats Publieke Gezondheid Limburg en de GGD Zuid Limburg stelden me in staat om binnen mijn werk vanuit mijn functie als beleidsmedewerker, onderzoek te doen naar gemeentelijk integraal gezondheidsbeleid.

Vanuit mijn jarenlange werkervaring had ik reeds gemerkt dat lokale samenwerking en afstemming van gemeentelijk beleid echt een meerwaarde kan hebben voor het ontwikkelen, implementeren en continueren van gezondheidsinterventies. Toen ik de kans kreeg om mezelf op dit vlak verder te professionaliseren, vond ik dat ik deze uitdaging aan moest gaan. Ook al betekende dit een duidelijke taak verzwaring voor mij in mijn werk en privé leven.

Mezelf kunnen blijven ontwikkelen en gebruik maken van alle talenten die ik in dit leven heb meegekregen gaven me de energie om dit traject succesvol af te ronden. Maar uiteraard heb ik de afgelopen vijf jaar veel steun ontvangen, daarom wil ik op deze plek een aantal mensen persoonlijk bedanken.

Natuurlijk begin ik dan met mijn begeleidingsteam; allereerst mijn co-promotor Maria Jansen. Maria ontzettend bedankt voor alle steun die ik van je heb mogen ontvangen de afgelopen jaren. Jij bent in mij blijven geloven en maakte ondanks je eigen overvolle agenda altijd tijd voor mij, geweldig! Jouw inzet en bevlogenheid zijn echt inspirerend! Het begeleidingsteam was natuurlijk niet compleet zonder mijn beide promotoren Nanne de Vries en Hans Maarse, bedankt voor jullie vertrouwen, steun en deskundigheid. We hadden een wat moeizame start samen, maar naarmate het traject vorderde en meer richting kreeg, groeide het wederzijdse vertrouwen en hebben we gezamenlijk hard gewerkt aan dit eindresultaat. Jullie vonden vaak dat ik alleen vanuit mijn positie bij de GGD sprak en meer moest proberen afstand te nemen van de praktijk en kritisch te reflecteren. Dit was moeilijk voor mij, maar ik heb er wel heel veel van geleerd, kennis die ik nu ook zelf binnen de GGD toepas.

Uiteraard wil ik ook de leden van mijn praktijkcommissie bedanken voor het meedenken bij het vormgeven van dit onderzoek en het delen van jullie expertise met mij. Allereerst natuurlijk Jacques Costongs die ondanks zijn drukke baan als wethouder binnen de gemeente Maastricht toch tijd wilde vrij maken voor dit onderzoek. Jouw creatieve gedachten en weidse vergezichten over integraal werken heb ik kunnen concretiseren binnen het onderzoek, je ideeën zorgde ook voor levendige discussies. Marian Hoeijmakers, jouw dissertatie heeft me mede geïnspireerd om me verder te verdiepen in het onderwerp integraal beleid. Joop ten Dam, bedankt voor je bijdrage die je samen met je collega's van het NIGZ hebt geleverd aan het begeleidingstraject binnen de negen Zuid-Limburgse gemeenten. Dit geldt ook voor het voormalige afdelingshoofd GB van de GGD Zuid Limburg Bert Hesdahl en alle GB-professionals die samen met het NIGZ de negen gemeenten hebben begeleid bij integraal werken. Onderzoek staat of valt natuurlijk met de bereidheid tot medewerking. Ik ben dan ook alle portefeuillehouders, managers en beleidsmedewerkers van de Limburgse gemeenten zeer erkentelijk voor hun deelname aan het onderzoek. En speciaal Peter Jager die als manager VGZ binnen de gemeente Maastricht bereid was samen met mij te reflecteren op de rol van het gemeentelijk management.

Verder waardeer ik het zeer dat de GGD Zuid Limburg en de Academische Werkplaats mij de gelegenheid hebben gegeven om mij binnen mijn werk op deze wijze verder te professionaliseren. Mijn afdelingshoofd Raymond Stijns wil ik speciaal bedanken voor de ruimte en steun die ik kreeg binnen de stafafdeling om te werken aan dit onderzoek en tegelijkertijd toch betrokken te blijven bij de belangrijke gemeentelijke beleidsprocessen binnen de afdeling. Dit proces was niet gemakkelijk, het urgentieniveau van praktijkvragen is altijd hoger dan dat van onderzoeksvragen, maar met steun van mijn directe collega's Petra Lamberts en Nanneke Thijssen is dit toch gelukt! Dames bedankt voor jullie begrip en steun de afgelopen jaren! Dit geldt ook voor mijn promotiemaatjes binnen de Academische Werkplaats, Nicole Boot en Anita Vermeer, collega Suhreta Mujakovic, oud-collega Mariken Leurs en alle anderen binnen de GGD. Zonder jullie was dit traject veel zwaarder geweest, het is fijn om te weten en te voelen dat je er niet alleen voor staat. Wies Weijts, jij was er altijd op de achtergrond en sprong vervolgens spontaan in om de eindredactie te doen, geweldig!

Naast woorden van dank gericht aan personen in mijn directe werkomgeving, wil ik natuurlijk alle vrienden en familie laten weten dat zij een enorme steun voor mij zijn geweest in de voltooiing van dit proefschrift.

Pap ik weet dat jij, samen met Mam, trots op me bent.

Nicolas en Etienne, ik ben trots op jullie en ik hoop dat jullie het beste uit jezelf halen.

Veranderingen zorgen voor nieuwe uitdagingen en andere toekomstperspectieven. Gedurende dit promotietraject is mijn leven flink veranderd en dat maakte het afronden van de dissertatie er niet makkelijker op. Maar deze veranderingen hebben me ook gesterkt. Ik ben klaar voor nieuwe uitdagingen. Ik begin aan een nieuwe levensfase, waarin naast werk vooral ook het genieten van het leven centraal zal staan.

Vergeven heeft niets te maken met goedkeuren of vrede hebben met wat een ander heeft gedaan, maar met het jezelf gunnen om het los te laten. 


\section{Curriculum Vitae}

Mieke Steenbakkers werd geboren op 12 februari 1964 in Acht (gemeente Eindhoven) Nederland. $\mathrm{Na}$ het behalen van haar VWO diploma aan het Bisschop Bekkers College te Eindhoven begon ze in 1983 aan de opleiding Gezondheidswetenschappen aan de Universiteit Maastricht. Ze volgde de afstudeerrichting Gezondheidsbevordering en tevens enkele modules van de afstudeerrichting Beleid en Beheer der Gezondheidszorgvoorzieningen. Zij heeft deze studie in 1987 succesvol afgerond met een afstudeeronderzoek naar de factoren die van invloed zijn op de keuze tussen het geven van borst- of flesvoeding.

Van 1988 tot 1991 werkt zij als onderzoeksmedewerker op de vakgroep GVO van de Universiteit Maastricht. Eerst ter ondersteuning van het project "Chronische lage rugpijn patiënten" en vervolgens voor het project 'Gezond Bergeyk'. Met name het community-project 'Gezond Bergeyk' heeft veel invloed gehad op haar toekomstige werkzaamheden. Eind 1991 begint zij als voorlichtingsonderzoeker te werken bij de Stichting Consument en Veiligheid in Amsterdam en is zij betrokken bij de ontwikkeling van nieuwe valpreventie-interventies voor ouderen. Ook heef zij voor deze organisatie een tweetal jaren als regioconsulent gewerkt in Limburg en diverse trainingen op het gebied van de kinderveiligheid verzorgd.

In 1997 begint haar werkcarrière bij de GGD. Tot 2005 heeft zij gewerkt bij de voormalige GGD Zuidelijk Zuid-Limburg in Maastricht en vanaf 2006 bij de huidige GGD Zuid Limburg in Geleen In Maastricht was zij als senior GVO-functionaris verantwoordelijk voor de coördinatie van he community onderdeel van het project 'Hartslag Limburg' binnen vier lage SES wijken in Maastricht en vier Zuid-Limburgse gemeenten. Binnen dit project had zij veel baat van de opgedane werkervaringen binnen het community project 'Gezond Bergeyk'. Zij heeft aan de wieg gestaan van vele innovatieve interventies die vanuit 'Hartslag Limburg' zijn ontwikkeld zoals; het project 'Goede Voeding hoeft niet veel te kosten' waaraan in 2003 de $0 G Z$ Stimuleringsprijs is toegekend, het L1 programma 'Hartslag Beweeg TeeVee', de publiek-private samenwerking met Van Melik Food Groep en het project 'Bewegen Zonder Zorgen'.

In 2006 begon zij als beleidsmedewerker bij het stafbureau van de GGD Zuid Limburg. Het opnieuw vormgeven van het relatiebeheer van de GGD met haar gemeenten was binnen deze functie voor haar een uitdaging. Zowel bestuurlijk als ambtelijk zijn nieuwe overlegvormen geïmplementeerd. Naast haar functie als stafmedewerker beleid is zij in 2007 begonnen als promovenda van de Academische Werkplaats Publieke Gezondheid Limburg. De GGD gaf haar de mogelijkheid om onderzoek te doen naar gemeentelijk gezondheidsbeleid. Zij heeft haa onderzoek gefocust op integraal gezondheidsbeleid, daar zij vanuit haar werkervaring binnen 'Hartslag Limburg' reeds had gezien en ervaren dat deze vorm van gezondheidsbeleid heel waardevol is om de publieke gezondheid daadwerkelijk te kunnen bevorderen. Naast haar promotietraject heeft zij in 2010 onder andere meegeschreven aan de eerste Zuid-Limburgse regionale Volksgezondheid Toekomst Verkenning en in 2011 aan de totstandkoming van de regionale gezondheidsnota 2012-2015 voor de gezamenlijke gemeenten in de regio ZuidLimburg.

Sinds april 2012 is zij als senior beleidsfunctionaris aangesteld bij de afdeling Kennis \& Innovatie van de GGD Zuid Limburg met als kerntaak het verbinden van praktijk, beleid en onderzoek zowel binnen de eigen organisatie als met en voor externe partners. In juni 2012 heeft zij op uitnodiging van de World Health Organization (WHO) haar onderzoeksresultaten gepresenteerd in een internationale drie daagse consultatie over "Impact Assessment as a tool for Multisectora Action on Health", in Kobe (Japan). Dit ter voorbereiding op de "8th Global Conference on Health Promotion" in Helsinki (Finland) in juni 2013 die focust op "Health in All Policies".

Inmiddels is zij, vanuit diverse functies, ruim 25 jaar actief op het vlak van de gezondheidsbevordering / Health Promotion. Dit proefschrift is een kroon op al het werk dat zij heeft gerealiseerd. 


\section{Overzicht publicaties}

2013

- Bekker M, Steenbakkers M, Storm I, Jansen M. (Forthcoming in 2013). From Instrument towards programme for HiAP decision-support? Health Impact Assessment in the Netherlands. In: O'Mullan et al. (eds). Integrating Health Impact Assessment into the Policy Process: Lessons and Experiences from Around the World.

\section{2}

Steenbakkers M, Jansen M, Maarse H, Vries N de. (2012). Challenging Health in All Policies, an action research study in Dutch municipalities. Health Policy 105 (2-3): 288-295.

- Steenbakkers M, Jansen M, Maarse H, Vries N de. (2012). Lokaal integraal gezondheidsbeleid: effecten van beleidsondersteuning op de ontwikkeling van gemeentelijke intersectorale samenwerking en integraal beleid. Tijdschrift voor Gezondheidswetenschappen 90 (3): 184-192.

- Steenbakkers M, Jansen M, Maarse H, de Vries N. (2012). Sturing op integraal gezondheidsbeleid: de rol van het gemeentelijke management. Tijdschrift voor Gezondheidswetenschappen 90 (2): 89-96.

2011

- Steenbakkers M, Jansen M, Hesdahl B, Dam J ten, Maarse H, Vries N de. (2011). Stimulating municipal government inter-sectoral collaboration: local support for the development of integrated health policy. European Journal of Public Health 21, supplement 1: 59.

- Steenbakkers M, Jansen M, Hesdahl B, Dam J ten, Maarse H, Vries N de. (2011). Gemeentelijke intersectorale samenwerking stimuleren: lokale begeleiding bij het ontwikkelen van integraal gezondheidsbeleid. Tijdschrift voor Gezondheidswetenschappen 89 (5): 266-273.

- Steenbakkers M, Lamberts P, Thijssen N, e.a. (1 juli 2011). Een gezonde koers voor Zuid-Limburg! Regionale nota gezondheidsbeleid Zuid-Limburg 2012-2015.

\section{0}

- Steenbakkers M, Jansen M, Maarse H, Vries N de. (2010). Integrated health policy: intersector collaboration from the municipal government's perspective. European Journal of Public Health 20, supplement 1: 272.

Steenbakkers M, Jansen M, Maarse H, Vries N de. (2010). Lokaal integraal gezondheidsbeleid intersectorale samenwerking vanuit het perspectief van gemeenten. Tijdschrift voor Gezondheidswetenschappen 88 (3): 136-143.

- Lamberts P, Steenbakkers M, Thijssen N, e.a. (juli 2010). Een gezonde kijk op Zuid-Limburg Regionale Volksgezondheid Toekomst Verkenning, Geleen.
- Steenbakkers M, Jansen M, de Vries NK (2009). Lokaal integraal gezondheidsbeleid versterken: welke ontwikkelingsmogelijkheden zien gemeenten eigenlijk? Tijdschrift voor Gezondheidswetenschappen 87 (3): 42.

- Steenbakkers M, Pos S, Dam J ten. (2009). Een routeplanner ter ondersteuning van de ontwikkeling van lokaal integraal gezondheidsbeleid. Tijdschrift voor Gezondheidswetenschappen 87 (3): 42-43.

2006

- Assema P van, Steenbakkers M, Bastiaens C, Ronda G. (2006). Hartslag Limburg: integrale gezondheidsbevordering in buurten, gemeenten, bij huisartsen en in het ziekenhuis. Het interventieproces van het community project binnen Hartslag Limburg. Tijdschrift voor Sociale Gezondheidszorg; 84 (4):231-237.

- Assema P van, Steenbakkers M, Stapel H, Keulen H van, Ronda G, Brug J. (2006). Evaluation of a Dutch public-private partnership to promote healthier diet. Amercian Journal of Health Promotion;20:309-312.

- Leurs M, Steenbakkers M, Jansen M. (februari 2006). Het schoolSlag praktijkboek, samen werken aan preventie op maat. GGD Zuid Limburg, Maastricht.

Ronckers ET, Groot W, Steenbakkers M, Ruland E, Ament A. (2006). Cost of the 'Hartslag Limburg' community Heart Health Intervention. BMC Public Health;6:51.

- Assema P van, Ronda G, Steenbakkers M, Quaedvlieg M, Brug J. (2006). The reach of a computer-tailored nutrition education program in the Dutch heart health community intervention "Hartslag Limburg”. Journal of Nutrition Education and Behavior; 38: 293-297.

\section{5}

- Steenbakkers M, Bastiaens C, Leurs M, Ruland E, Jansen M. (2005). Vijf jaar communitybased werken in Hartslag Limburg (1998-2003). Ervaringen uit de praktijk. Tijdschrift voor Sociale Gezondheidszorg;83 (2):108-112

- Assema P van, Steenbakkers M, Rademakers C, Brug J. (2005). The impact of a nutrition education intervention on main meal quality and fruit intake in people with financial problems. Journal of Human Nutrition and Dietetics;18:205-212.

- Ronda G, Assema Pvan, Candel M, Ruland E, Steenbakkers M, Ree J van, Brug J. (2005). The Dutch heart health community intervention 'Hartslag Limburg': results of an effect study at organizational level. Public Health;119:353-360.

- Assema P van, Steenbakkers M, Rademakers C, Brug J. (2005). Voedingsvoorlichting voor mensen met financiële problemen: effect op de kwaliteit van de hoofdmaaltijd en de fruitconsumptie. Nederlands Tijdschrift voor Diëtisten;60:116-124. 
- Vermeer A, Steenbakkers M, Munter H de, Leurs M. (april 2005). Op weg naar een gezonde school, nieuw leefstijlprogramma voor bovenbouw havo/vwo. Tijdschrift Niche: 13-16.

\section{4}

- Steenbakkers M, Rademakers C, Assema P van. (15 april 2004). Evaluatie van het project "Goede voeding hoeft niet veel te kosten". Nederlands congres Volksgezondheid 2004 Rotterdam. TSG 2004;82(3):41.

- Ronda G, Assema P van, Candel M, Ruland E, Steenbakkers M, Ree J van, Brug J. (2004). The Dutch heart health community intervention 'Hartslag Limburg': effects on smoking behaviour. European Journal of Public Health;14:191-193.

- Ronda G, Assema Pvan, Candel M, Ruland E, Steenbakkers M, Van Ree J, Brug J. (2004). The Dutch heart health community intervention 'Hartslag Limburg': results of an effect study at individual level. Health Promotion International;19 (1):21-31.

- Ronda G, Assema P van, Ruland E, Steenbakkers M, Brug J. (2004). The Dutch heart health community intervention 'Hartslag Limburg': design and results of a process study. Health Education Research;19(5):596-607.

\section{3}

- Ronda G, Assema P van, Ruland E, Steenbakkers M, Brug J. (2003). The Dutch heart health community intervention 'Hartslag Limburg': evaluation design and baseline data. Health Education;103(6):330-341.

- Steenbakkers M. (2003). Armentoch gezond, gezondheidsbevordering enschuldhulpverlening gaan in Maastricht hand in hand. G Vakblad over Gezondheid en Maatschappij (2):26-27.

- Ruland E, Harting J, Limpt P van, Ronda G, Steenbakkers, M Ronckers S, et al. (july 2003). Hartslag Limburg Progress Report no. 4; a field project report within the framework of WHO's 'Towards Unity For Health' project. Maastricht, GGD ZZL.

\section{2}

- Steenbakkers M, Bastiaens C. (april 2002). Tegen de stroom in! Regionale stoppen-metroken activiteiten vanuit Hartslag Limburg. Defactor: 14-15.

- Steenbakkers M, Bastiaens C, Ronda G. (april 2002). Goede voeding hoeft niet veel te kosten. Het project Hartslag Limburg en het verkleinen van sociaal-economische gezondheidsverschillen. GGD Nieuws: 20-22.

- Ruland E, Harting J, Limpt P van, Ronckers S, Ronda G, Steenbakkers M, et al. Iseptember 2002). TUFH progress report no. 3. a field report within the framework of WHO's 'Towards Unity For Health" project. Maastricht, GGD ZZL.
- Ronckers S, Ament A, Steenbakkers M, Ruland E. (november 2001). De kosten van het community project van Hartslag Limburg. Een kosten analyse op activiteitenniveau. GGDnieuws, pp.27-32.

Ronda G, Steenbakkers M, Assema van P. Ruland E. (april 2001). Hartslag Beweeg TeeVee: Een provinciaal programma voor bewegingsstimulering. GGD Nieuws, pp. 21-27.

- Ruland E, Harting J, Limpt P van, Nicolaïdes A, Ronckers S, Ronda G, Steenbakkers M. Cruijsem M van de, Assema P van, Ree J van, Vermeer F, Ament A. (december 2001). Hartslag Limburg Progress Report no. 2; a field project report within the framework of WHO's 'Towards Unity For Health' project. Maastricht, GGD ZZL.

- Ruland E, Harting J, Limpt P van, Ronckers S, Ronda G, Steenbakkers M. Assema P van, Ree J van, Gorgels T, Vermeer F, Ament A. (july 2001). Hartslag Limburg Progress Report no. 1 Baseline data from the Hartslag Limburg project, Maastricht, GGD ZZL.

- Steenbakkers M, Ruland E. (2000). Hartslag Limburg, samen gezond. Integrale gezondheidsbevordering in gemeenten, buurten, huisartspraktijken en het ziekenhuis. GGD Nieuws, 10: 5-9.

\section{6}

- Steenbakkers M, e.a. (1996). Promotie Vrijwillig gebruik van fietshelmen in de Bollenstreek. De resultaten van een pilot project bij twee basisscholen. Amsterdam, Stichting Consument en Veiligheid.

\section{4}

Steenbakkers M. (1996). Van doelgroep tot interventiestrategie. Ouderen en het bevorderen van de privé-veiligheid. Senior; 10: 10-12.

- Steenbakkers M. (1994). Opgedane ervaringen met het analyse-instrument: het deelterrein ouderen nader geanalyseerd. In: W. van Driel e.a. Effectiviteitsanalyse van GVO/GGZ preventie interventies, ontwikkeling van een analyse-instrument. Utrecht, Landelijk Centrum GVO: 27-30.

Steenbakkers M. (1994). Van doelgroep tot interventiestrategie. Ouderen en het bevorderen van de privé-veiligheid. GGD-nieuws; 6: 26-28.

- Steenbakkers M. (december 1994). Samenwerken aan kinderveiligheid. Lokale veldverkenning naar het kinderveiligheidsklimaat binnen de gemeente Maastricht. Amsterdam, Stichting Consument en Veiligheid.

- Assema P van, Steenbakkers M, Kok G, Eriksen M, Vries H de. (1994-95). Results of the Dutch community project "Healthy Bergeyk". Preventive Medicine; 23: 394-401.

- Assema P van, Steenbakkers M, Eriksen M, Kok G. The process evaluation of a Dutch 
community health project. International Quarterly of Community Health Education: 2: 187-207.

- Keijsers JFEM, Steenbakkers WHL, Gerards FM, Bouter LM, Meertens RM. (1990). The efficacy of the back school, an analysis of the literature. Arthritis Care and Research; 3: 210-215.

\section{3}

- Raaijmakers C, Steenbakkers M. (december 1993). Het project “Wijzer Wonen”. Evaluatie van groepsvoorlichting aan ouderen over privé-veiligheid. Rapport nr: 147, Stichting Consument en Veiligheid, Amsterdam.

\section{2}

- Steenbakkers M, Geus G de, Ooms M, Bos A. (1992). Veiligheidsvoorlichting, Werken met paraprofessionele veiligheidsvoorlichters. Het voorlichtingsproject 'Veilig op Leeftijd' geëvalueerd. Tijdschrift Gezondheidsvoorlichting; 10: 19-21.

- Steenbakkers M, Voorlichtingsplan Ouderen en Veiligheid. (1992). Intern rapport nr.96, Stichting Consument en Veiligheid, Amsterdam.

- Assema P van, Kok GJ, Steenbakkers M. (1992). Het gezondheidsproject Bergeyk: resultaten van de proces- en effectevaluatie. Nederlands Tijdschrift voor Diëtisten; 47-9: 224-228.

1991

- Steenbakkers M, Assema P van, Gabriëls-Stensen D, Kok GJ. (1991). Project Gezond Bergeyk: De ontwikkeling en implementatie van een lokaal gezondheidsproject. In: E. de Leeuw (red.) Gezonde steden. Lokale gezondheidsbevordering in politiek, theorie en praktijk. Van Gorcum, Assen/Maastricht: 225-248.

- Assema P van, Steenbakkers M, Kok G. (1991). Het lokale gezondheidsproject "gezond Bergeyk". Een beschrijving van de projectactiviteiten en een verslag van de resultaten van de proces-evaluatie. Maastricht, Rijksuniversiteit Limburg, GVO-cahier nr. 52.

1990

- Keijsers JFEM, Steenbakkers WHL, Meertens RM, Bouter LM, Kok GJ. (1990). The efficacy of the back school, A Randomized Controlled Trail. Arthritis Care and Research; 3: 204-209.

- Keijsers JFEM, Steenbakkers WHL, Meertens RM, Gerards FM, Kok GJ. (1990). Modelontwikkeling aangaande voorlichting voor chronisch lage rugpijn patiënten. Eindverslag. Universiteit Maastricht.
1989

- Keijsers JFEM, Groenman NH, Gerards FM, Van Oudheusden E, Steenbakkers M. (1989). A back school in the Netherlands: Evaluating the results. Patient Education and Counseling. 1989;14:31-44

- Keijsers JFEM, Bouter LM, Steenbakkers WHL, Meertens RM. (1989). Methodologische kwaliteit \& onderlinge vergelijkbaarheid van onderzoek naar de effectiviteit van rugscholen. Nederlands Tijdschrift voor Fysiotherapie; 99 (5): 112-116.

\section{7}

- Steenbakkers WHL. (1987). Determinanten van zuigelingenvoeding. Een studie naar de factoren die van invloed zijn op de keuze tussen borst en flesvoeding en op de duur van borstvoeding onder moeders met een eerste kind in Maastricht. Maastricht, Rijksuniversiteit Limburg, afstudeerscriptie GVO. 


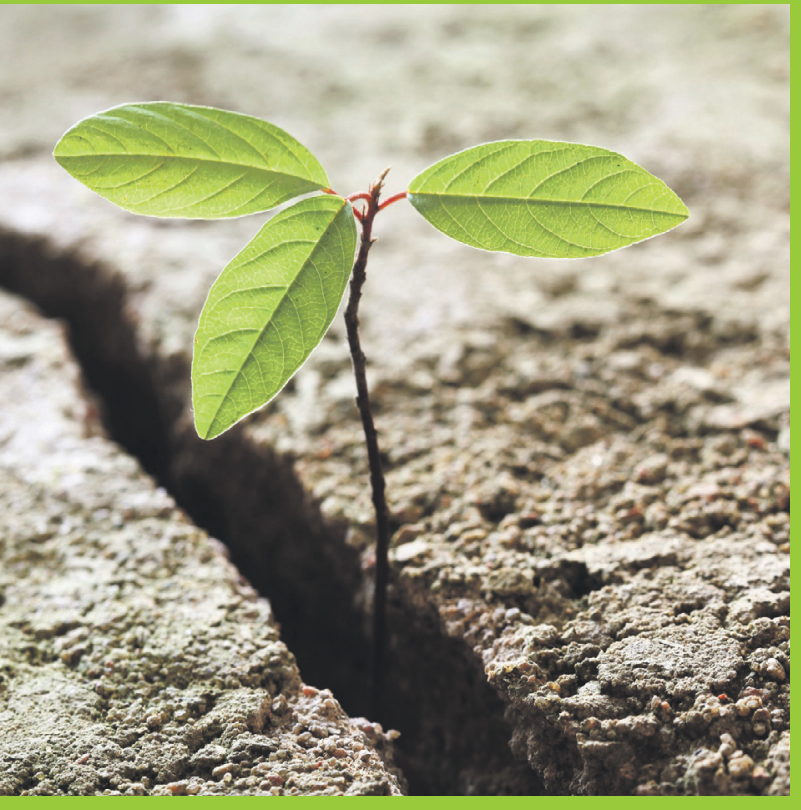

